CAMILLA RIBEIRO MARTES

\title{
SOBRE O CONTROLE MINORITÁRIO NAS COMPANHIAS LISTADAS NO NOVO MERCADO
}

Dissertação de Mestrado

Orientadora: Professora Doutora Juliana Krueger Pela

Faculdade de Direito da Universidade de São Paulo

São Paulo

2014 
Camilla Ribeiro Martes

\section{SOBRE O CONTROLE MINORITÁRIO NAS COMPANHIAS LISTADAS NO NOVO MERCADO}

Dissertação apresentada à Faculdade de Direito da Universidade de São Paulo como requisito parcial para obtenção de título de Mestre.

Área de Concentração: Direito Comercial

Orientação: Professora Doutora Juliana Krueger Pela

Faculdade de Direito da Universidade de São Paulo

São Paulo

2014 
Autorizo a reprodução e divulgação total ou parcial deste trabalho, por qualquer meio convencional ou eletrônico, para fins de estudo e pesquisa, desde que citada a fonte.

Serviço de Biblioteca e Documentação

Faculdade de Direito da Universidade de São Paulo

Martes, Camilla Ribeiro.

M332s Sobre o controle minoritário nas companhias listadas no novo mercado / Camilla Ribeiro Martes. - - São Paulo: USP / Faculdade de Direito, 2014.

$188 \mathrm{f}$.

Orientadora: Prof ${ }^{a}$. Dra. Juliana Krueger Pela

Dissertação (Mestrado), Universidade de São Paulo, USP, Programa de Pós-Graduação em Direito, 2014.

1. Mercado de Capitais. 2. Controle Acionário. 3. Acionista Minoritário. 4. Governança Corporativa. I. Pela, Juliana Krueger. II. Universidade de São Paulo, Faculdade de Direito, Programa de PósGraduação em Direito. III. Título. 
Nome: MARTES, Camilla Ribeiro

Título: Sobre o controle minoritário nas companhias listadas no Novo Mercado

Dissertação apresentada à Faculdade de Direito da Universidade de São Paulo como requisito parcial para obtenção de título de Mestre em Direito Comercial.

Aprovado em:

Banca Examinadora

Prof. Dr. Instituição:

Julgamento:

Assinatura:

Prof. Dr. Instituição:

Julgamento:

Assinatura:

Prof. Dr. Instituição:

Julgamento: Assinatura: 
À minha mãe, Eunice, e à memória de meu pai, Orlando, com todo amor e admiração. 


\section{AGRADECIMENTOS}

Agradeço ao meu avô, Heródoto, por ter ensinado à minha mãe que a melhor herança que um pai pode deixar a um filho é a educação.

À minha mãe, Eunice, por fazer valer os ensinamentos de meu estimado avô, pelos valores e princípios que me permitiram ser quem eu sou, e pelo exemplo de dedicação e perseverança em meio a tantas adversidades da vida.

Ao meu irmão, que, embora já adulto, será sempre o Orlandinho, meu melhor amigo, presente em todos os momentos de angústia e felicidade, não podendo deixar de acompanhar de perto cada passo da evolução do presente estudo para que esse sonho se tornasse possível.

À minha amada avó, Marina, segunda mãe, presente em todas as horas e orações, sempre torcendo pela concretização deste curso.

Às minhas amigas, excelentes advogadas, Maira, Camilla e Paula, que me encorajaram, desde o princípio, a seguir esta jornada, e a todos os demais amigos pelo apoio, paciência e compreensão durante a elaboração da presente dissertação, contribuindo, mesmo que indiretamente, para a conclusão deste curso.

Agradeço à Faculdade de Direito da Universidade de São Paulo e aos meus professores do Mestrado pelo excelente programa de pós-graduação e por terem contribuído decisivamente na condução deste estudo, em especial à minha orientadora, Profa. Dra. Juliana Krueger Pela, sem a qual este trabalho jamais se tornaria possível, por todo empenho, atenção, paciência e credibilidade depositados em mim, obrigada por tudo. 


\section{RESUMO}

MARTES, Camilla Ribeiro. Sobre o controle minoritário nas companhias listadas no Novo Mercado. 2014. 188 f. Dissertação (Mestrado em Direito Comercial) - Faculdade de Direito da Universidade de São Paulo, São Paulo, 2014. Orientação: Professora Doutora Juliana Krueger Pela.

Dentre os atuais desafios do direito societário brasileiro, a estrutura da propriedade acionária das sociedades por ações de capital aberto e a identificação daqueles que as comandam merecem destaque. $\mathrm{O}$ aquecimento das transações realizadas via mercado de capitais e a consolidação dos segmentos especiais de governança corporativa no Brasil resultaram no chamado fenômeno de dispersão acionária, que evidenciou certa ruptura na tradicional estrutura de propriedade acionária exclusivamente concentrada, até então predominante nas companhias brasileiras. Diante desse cenário contrastante, de mudanças no perfil do poder de controle sobre as companhias brasileiras, o presente trabalho apresentará em seu capítulo terceiro, após breve análise das estruturas de capital identificadas em diferentes economias e de retrospectiva sobre a propriedade acionária das companhias brasileiras (a serem apresentadas em seu segundo capítulo), extensa pesquisa empírica realizada com o propósito de identificar a atual estrutura de propriedade acionária predominante entre as companhias brasileiras listadas no segmento especial do Novo Mercado da BMF\&BOVESPA (Novo Mercado), e com o objetivo de averiguar a existência do chamado controle societário minoritário entre tais companhias, conforme detalhado nos apêndices desta dissertação. Referida pesquisa empírica representa, ainda, rico processamento da base de dados e informações divulgadas à Comissão de Valores Mobiliários (CVM) pelas companhias listadas no Novo Mercado, e serve de base para a avaliação da necessidade de eventuais mudanças nos conceitos adotados pelo Direito Societário pátrio, tendo em vista entendimento divergente identificado na doutrina e em julgados da CVM no âmbito da possibilidade de existência de um controle societário exercido por acionista ou grupo de acionistas não detentores da maioria do capital social votante, conforme detalhado no quarto capítulo deste estudo. Por fim, serão apresentadas, no quinto e último capítulo, as considerações finais à análise proposta, com destaque para as principais conclusões obtidas na elaboração dos capítulos terceiro e quarto descritos acima, dentre elas a existência do controle societário interno não majoritário (controle minoritário) entre companhias listadas no Novo Mercado, bem como os reflexos dessa constatação no âmbito da prática do Direito Societário.

Palavras-chave: Controle. Controle societário. Controle interno. Controle minoritário. Controle compartilhado. Novo Mercado. Governança corporativa. Estrutura de capital. Propriedade do capital. Capital disperso. Capital pulverizado. Pílulas de veneno (poison pills). Acordo de acionistas. 


\begin{abstract}
MARTES, Camilla Ribeiro. About the minority control in companies listed in the New Market segment. 2014. 188 p. Dissertation (Master's Degree in Commercial Law) - Law School of the University of São Paulo, São Paulo, 2014. Supervisor: Ph.D. Professor Juliana Krueger Pela.

Among the current challenges of the Brazilian Corporate Law, the structure of the capital ownership of the corporations and the identification of those who exercises control over it remains an important aspect to be taken into consideration when analyzing the main aspects of the Brazilian capital market. The heat up of the transactions carried out through the capital market, and the consolidation of the special corporate governance segments in Brazil resulted in the so called phenomenon of the dispersed ownership, which revealed a rupture from the traditional structure of extremely concentrated ownership, that was prevailing until now among the Brazilian corporations. Given such contrasting scenario of changes in the profile of corporate power over Brazilian corporations, these thesis, after describing, over its first two chapters, the structures of capital ownership existent in different economies and providing a retrospective on the capital ownership of Brazilian corporations, presents, in its third chapter, an extensive empirical research performed with the purposes of identifying the current structure of capital ownership prevailing among the Brazilian companies listed in the Novo Mercado, special segment of the Brazilian Exchange BMF\&BOVESPA (the New Market), as well as ascertaining the existence of minority corporate control among such companies, as detailed in the appendixes hereto. The referred empirical research presents, furthermore, detailed data processing in connection with the information disclosed by such companies to the Brazilian Stock Exchange Commission, the Comissão de Valores Mobiliários (CVM), and is also used as basis for reviewing the need of eventual changes in the concepts embodied by the Brazilian Corporate Law, in view of the divergent understanding identified in the Brazilian doctrine and judgments issued by the CVM in connection with the existence of a corporate control exercised by a shareholder or group of shareholders owner of shareholding not representative of the majority of the voting capital stock, as detailed in the fourth chapter of these thesis. Finally, the fifth and last chapter of these study presents the final considerations in connection with the review proposed hereto, highlighting the main conclusions obtained through the elaboration of the third and fourth chapters described above, among them the existence of a not majority internal control (minority control) in companies listed in the New Market, as well as the effects of such conclusion in the light of the practice of corporate law.
\end{abstract}

Key words: Control. Corporate control. Internal control. Minority control. Shared control. New Market (Novo Mercado). Corporate governance. Capital structure. Dispersed ownership. Pulverized capital. Poison pills. Shareholders agreement. 


\section{SUMÁRIO}

\section{CAPÍTULO 1 \\ INTRODUÇÃO}

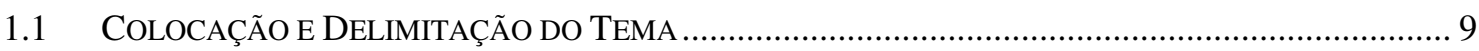

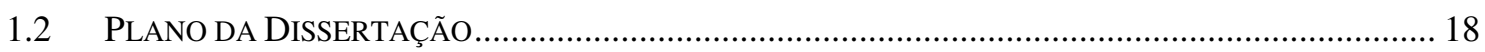

\section{CAPÍTULO 2}

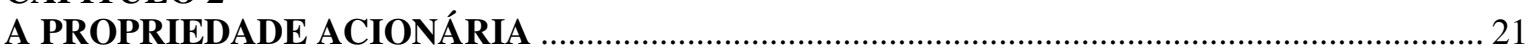

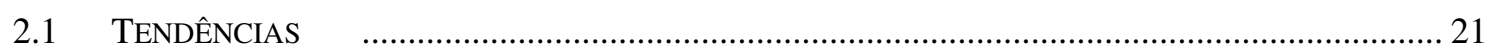

2.2 A PROPRIEDADE ACIONÁRIA NAS COMPANHIAS BRASILEIRAS ............................................... 29

\section{CAPÍTULO 3}

CENÁRIO DAS COMPANHIAS LISTADAS NO NOVO MERCADO ............................................. 42

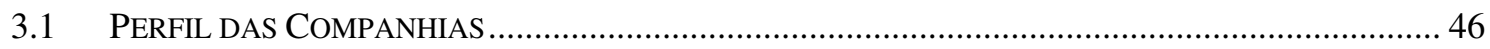

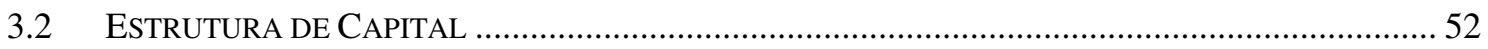

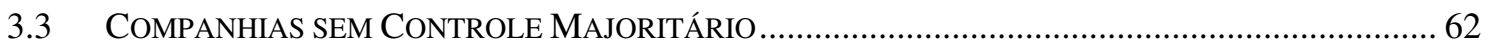

3.3.1 PERFIL DOS ACIONISTAS E GRAU DE DISPERSÃo ……………............................................ 63

3.3.2 ACORDO DE ACIONISTAS - PRINCIPAIS DISPOSIÇÕES ………………………................. 71

3.3.3 POISON PILLS - PRINCIPAIS ESTRUTURAS AdOTADAS ….................................................... 82

\section{CAPÍTULO 4}

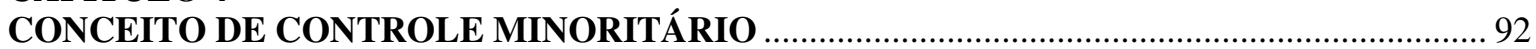

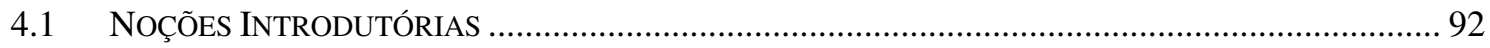

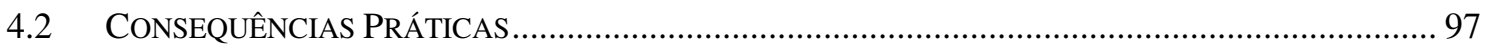

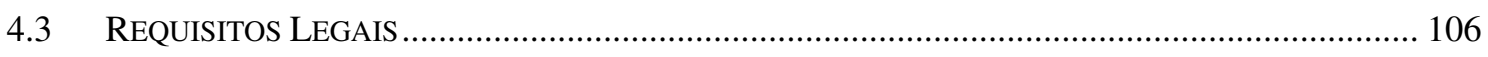

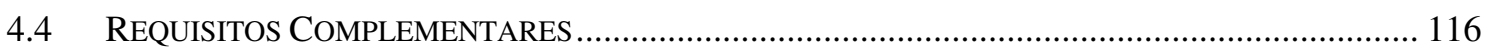

\section{CAPÍTULO 5}

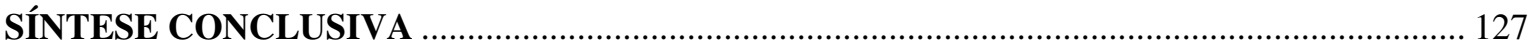

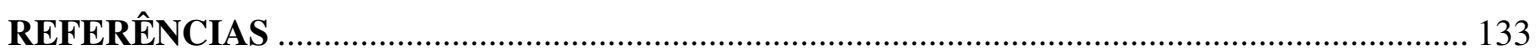

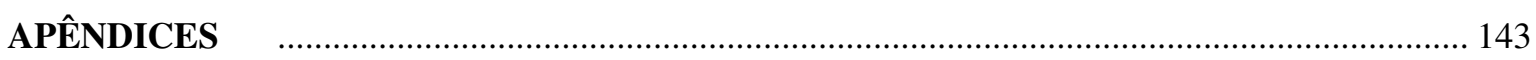

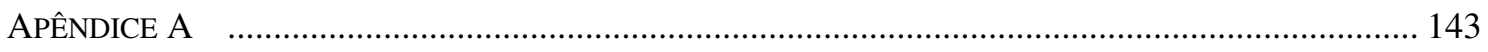

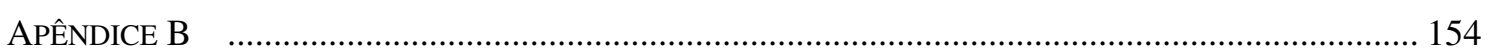

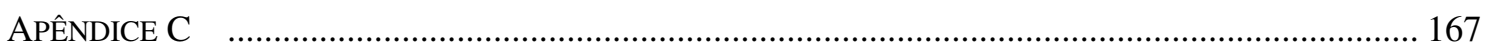

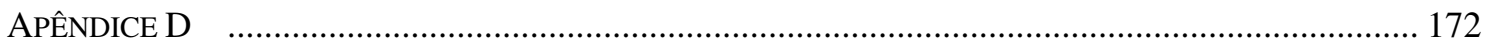

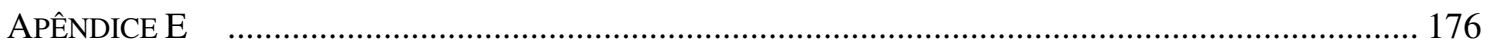

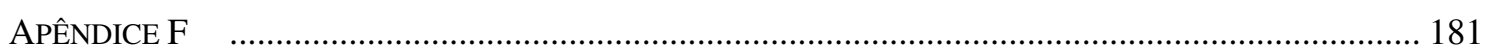




\section{CAPÍTULO 1 INTRODUÇÃO}

\subsection{Colocação e Delimitação do Tema}

Ao final da década de 1980, marcada pela desregulamentação dos mercados financeiro e de capitais dos Estados Unidos, acionistas de grandes companhias norteamericanas passaram a atentar para a necessidade de adoção de regras que os protegessem de atos abusivos praticados pelos diretores, da inércia dos membros dos conselhos de administração e de omissões das auditorias independentes, entre outros.

O movimento era claro. Diante do conflito de agência existente entre acionistas e administradores das grandes companhias abertas norte-americanas, os acionistas passaram a exigir a adoção de medidas que assegurassem o devido retorno de seus investimentos, de tal sorte que a adoção de criteriosos elementos de governança corporativa tornou-se requisito essencial para um bom retorno de investimento. Nesse contexto, diversos estudos foram divulgados, com destaque para a ideia de que a evolução do mercado de capitais dependia diretamente do nível de proteção atribuído aos acionistas, em especial aos acionistas minoritários ${ }^{1}$.

No cenário brasileiro, fatores ainda que diversos também favoreceram a identificação de movimento semelhante ao surgido nos Estados Unidos. A aprovação do Plano Real e os processos de privatização, assim como o fenômeno da globalização e da própria desregulamentação da economia em geral, ressaltaram a necessidade de modernização das companhias brasileiras e a urgência por mudanças que tornassem o investimento via mercado de capitais mais atrativo no Brasil. Dentre os fatores que prejudicavam a atratividade do mercado de capitais brasileiro, restava sobretudo a inadequação de sua disciplina, que não oferecia direitos e garantias suficientes aos seus investidores.

\footnotetext{
${ }^{1}$ Nesse sentido: LA PORTA, Rafael; LOPEZ-DE-SILANES, Florêncio; SHLEIFER, Andrei; VISHNY, Robert W. Legal determinants of external finance. The Journal of Finance, v. LII, p. 1131-1150, paper $\mathrm{n}$. 1840, July, 1998.
} 
Diversas medidas foram tomadas, ao final da década de 1990 e início dos anos 2000, com o objetivo de conferir maior proteção aos investidores, em especial aos acionistas minoritários em face do conflito existente entre controladores e minorias: (i) em 1999, o Instituto Brasileiro de Governança Corporativa (IBGC) divulgou o primeiro Código de Melhores Práticas de Governança Corporativa; (ii) em 2000, antiga Bolsa de Valores de São Paulo (Bovespa) criou os segmentos especiais de governança corporativa; (iii) em 2001, foi aprovada a reforma da Lei $\mathrm{n}^{\mathrm{0}}$ 6.404, de 15 de dezembro de 1976 (Lei das S.A.), com atenção especial aos acionistas minoritários; e (iv), em 2002, a Comissão de Valores Mobiliários (CVM) divulgou cartilha com recomendações sobre Governança Corporativa.

Em paralelo, estudos sobre o tema, como os de Carvalho (2002, 2003) e Santana (2008), evidenciavam melhorias no mercado de capitais brasileiro, em decorrência da possibilidade de adesão a segmentos especiais de governança corporativa por um maior número de companhias, bem como enalteciam os benefícios gerados para as próprias companhias em consequência de tal adesão, dentre eles: (i) o aumento no valor e liquidez das ações; (ii) a diminuição dos custos de capital; e (iii) o aumento do interesse pela companhia por um maior número de investidores.

Dadas as melhorias na regulação do mercado de capitais brasileiro e a contribuição do contexto econômico, o mercado de capitais brasileiro iniciou uma nova era de consolidação e evolução. Após longos períodos de retração econômica, finalmente é possível observar momentos de prosperidade no mercado brasileiro, com resultados reais de desenvolvimento econômico, acompanhados por uma cultura de investimento mais sólida - ainda que singela, perto daquela identificada em nações mais desenvolvidas.

Na última década, houve forte crescimento no volume de negociações via mercado de capitais. A exemplo, como se pode depreender do Gráfico 1, que apresenta o volume total de negociações realizadas mediante ofertas de ações primárias e secundárias, no período compreendido entre os anos de 2001 e 2013, houve expressivo crescimento na quantidade e nos valores captados por meio de ofertas de ações: 
Gráfico 1 - Capital levantado com ofertas de ações ${ }^{2}$

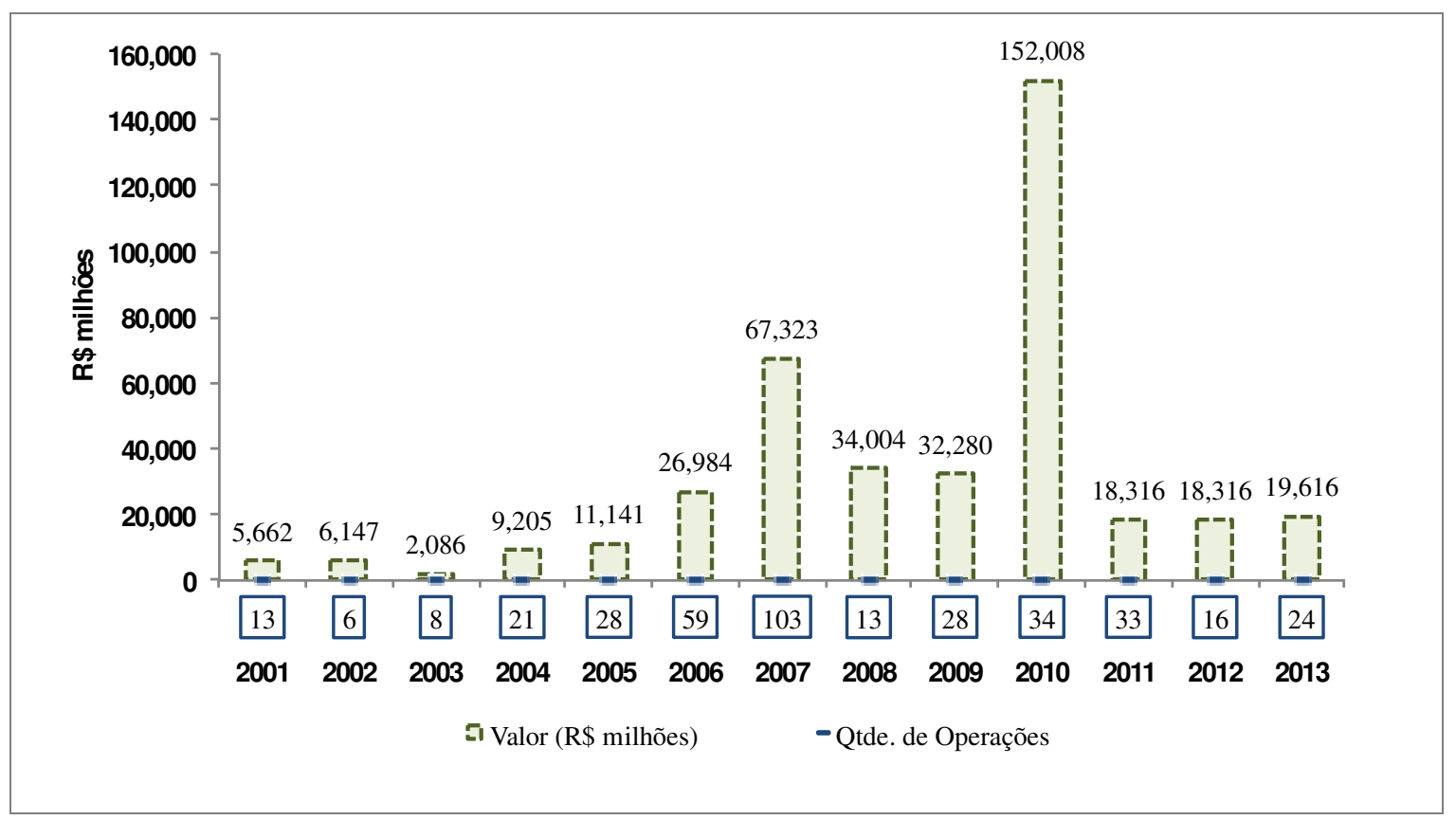

Fonte: CVM - Ofertas Registradas

Seguindo o mesmo movimento, foi possível identificar, ainda, a consolidação dos segmentos especiais de governança corporativa da BM\&FBOVESPA S.A. Bolsa de Valores Mercadorias e Futuros (BM\&FBOVESPA), principalmente, o segmento do Novo Mercado, tido como mais rigoroso.

O Gráfico 2 apresenta o total de companhias listadas em cada segmento especial, no período entre os anos de 2001 e 2013, considerando-se as listagens em ofertas primárias e eventuais migrações entre segmentos ocorridas durante cada ano levantado. Como se pode notar, houve expressivo aumento no número de companhias listadas no Novo Mercado, desde a sua criação.

\footnotetext{
${ }^{2}$ Gráfico elaborado com base em estatísticas divulgadas pela CVM sobre total de ofertas registradas em cada exercício social. Informações disponíveis em: <www.cvm.gov.br>. Acesso em: 20 jan. 2014. Vale destacar que o expressivo valor apresentado para as operações conduzidas em 2010 engloba o montante de R \$115.052.319.090,80, objeto da oferta global conduzida pela Petróleo Brasileiro S.A. (Petrobras), em setembro do mesmo ano.
} 
Gráfico 2 - Evolução dos segmentos de listagem da BM\&FBOVESPA ${ }^{3}$ ]

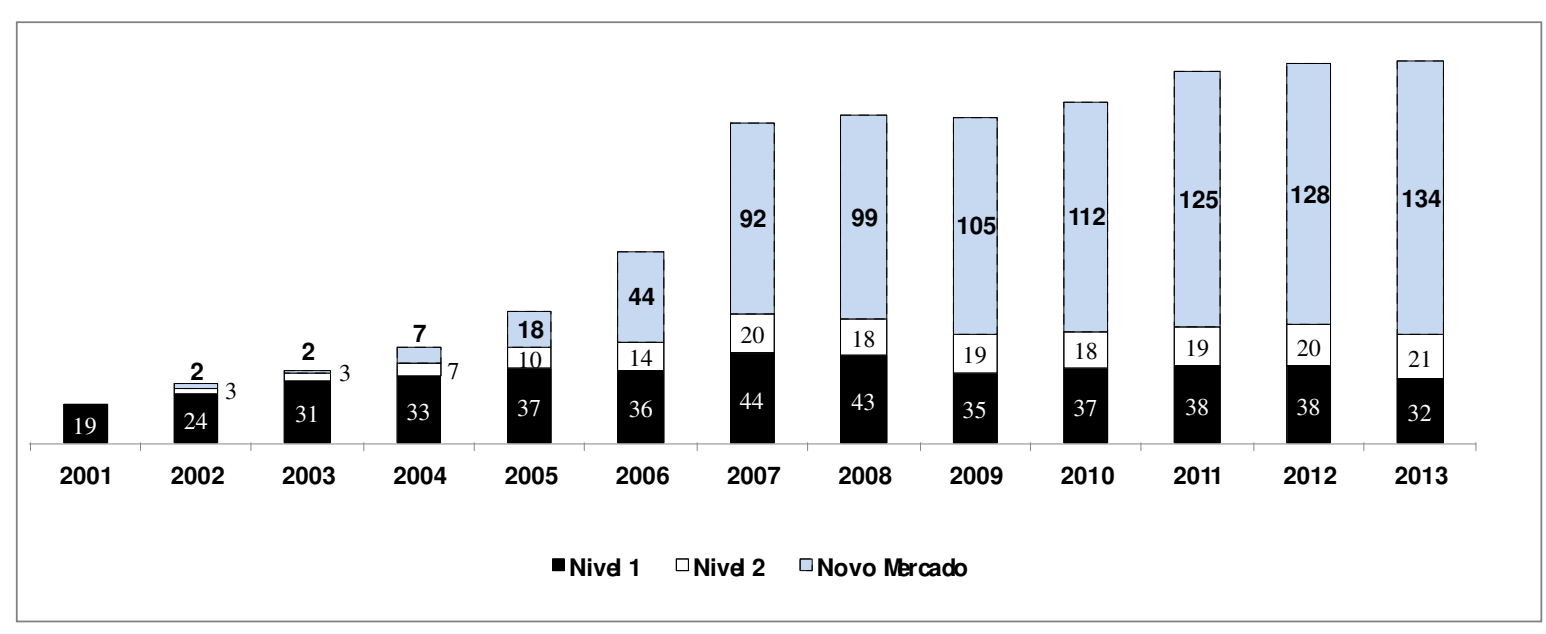

Fonte: BM\&FBOVESPA - BDI

O aquecimento do mercado de capitais e a consolidação dos segmentos especiais de governança corporativa, tal como evidenciados acima, ocasionaram certa alteração na estrutura de capital das companhias abertas brasileiras, ao gerarem maior dispersão do capital no mercado. Houve, portanto, um movimento de ruptura da tradicional estrutura de capital exclusivamente concentrado.

O aumento do número de companhias listadas no Novo Mercado evidencia certa redução no nível de concentração acionária até então identificado no mercado brasileiro, considerando tanto o aumento de companhias que abriram seu capital para a listagem no referido segmento, como a necessidade de capital dividido exclusivamente por ações ordinárias.

Da mesma forma, ainda que se não tenha atingido nível relevante de dispersão acionária no País, a existência, por exemplo, de companhias com capital em elevado grau de dispersão acionária (denominadas com capital pulverizado) já é uma realidade. Como exemplo não exaustivo, as seguintes companhias listadas no Novo Mercado se enquadravam nesse cenário, em julho de 2012: (i) Gafisa S.A., na qual não havia um acionista com participação societária superior $5 \%$ de seu capital social total, tampouco acordo de acionistas arquivado na sede social; (ii) Embraer S.A., na qual os maiores acionistas da companhia, Caixa de Previdência dos Funcionários do Banco do Brasil (Previ) e Oppenheimer Funds, detinham, respectivamente, participação correspondente a

\footnotetext{
${ }^{3}$ Informações levantadas com base no número de empresas registradas em cada segmento especial, conforme apresentado nos Boletins Diários de Informações da BM\&FBOVESPA, divulgados ao final de cada exercício social. Disponível em: <http://www.acervobmfbovespa.com.br/>. Acesso em: 20 jan. 2014.
} 
$10,43 \%$ e $8,44 \%$ do capital social da companhia, sendo que não havia qualquer acordo de acionistas arquivado na sede social; e (iii) Renner S.A., que também não possuía acordo de acionistas arquivado em sua sede social, e seus três maiores acionistas, os gestores de investimentos Aberdeen Asset Management Plc e Blackrock Inc., detinham, respectivamente, $14,47 \%$ e $7,29 \%$ do capital social total ${ }^{4}$.

Ora, o processo de abertura de capital de uma companhia e sua adesão a regras de um segmento especial de governança corporativa resultam obrigatoriamente em alguma diluição dos antigos controladores da companhia, ainda que estes permaneçam no comando das atividades sociais.

No caso de um alistamento no Novo Mercado, por exemplo, os requisitos de manutenção de um percentual mínimo de ações em circulação e de emissão exclusiva de ações ordinárias refletem em movimentos de dispersão acionária. O mesmo ocorre diante da necessidade do acionista, então integrante do bloco de controle, de minimizar os riscos de sua exposição aos negócios da companhia, o que, na maioria dos casos, leva-o a optar pela abertura do capital e diluição em sua participação acionária.

Conforme demonstrado, a evolução do mercado de capitais e do direito societário brasileiro é inegável. Além dos benefícios econômicos, houve, também, amadurecimento no perfil de atuação dos acionistas minoritários brasileiros. A esse respeito, dois casos emblemáticos de atuação de acionistas não integrantes do bloco de controle merecem destaque. $\mathrm{O}$ primeiro se refere à eleição de novos membros do Conselho de administração da Diagnósticos da América S.A., na Assembleia Geral Ordinária realizada em 28 de abril de 2009, quando os acionistas minoritários da companhia, dentre eles os fundos de investimento Credit Suisse Hedging-Griffo, HSBC e Fundação Vale do Rio Doce da Seguridade Social, alinharam-se para formar uma nova composição do conselho da companhia, a despeito da chapa candidata à reeleição, formada por Caio Auriemo e Alexandre Saigh.

Na mesma linha, a incorporação de ações de emissão da Bradesco Dental S.A. pela Odontoprev S.A., e consequente transferência de ações de emissão da Odontoprev para a Bradesco Saúde S.A. com o objetivo de integrar as atividades desenvolvidas pela Odontoprev e Bradesco Dental, também merece relevo. De forma a garantir a aprovação da operação de incorporação, a Bradesco Saúde firmou compromisso de voto com diversos

4 Participações levantadas de acordo com informações divulgadas pelas respectivas companhias à BM\&FBOVESPA. Disponível em: <http://www.bmfbovespa.com.br/cias-listadas/empresas-listadas/ BuscaEmpresaListada.aspx?idioma=pt-br>. Acesso em: 11 jul. 2012. 
fundos de investimento acionistas detentores de, aproximadamente, 37,4\% do capital social da Odontoprev, que, até então, possuía seu capital extremamente disperso no mercado.

Não obstante, embora seja possível notar, no âmbito nacional, movimentos de forte atuação de acionistas minoritários, bem como um fenômeno de dispersão acionária resultante de crescente tendência à abertura do capital de companhias de médio e grande portes, as estruturas de capital concentrado persistem no País, sendo ainda muito comum a presença do acionista controlador nas companhias brasileiras de capital aberto.

Ao analisarem os limites dos benefícios privados que podem ser obtidos por acionistas controladores, Gilson e Gordon (2003) baseiam o estudo elaborado em três meios de extração de tais benefícios, que ainda podem ser vislumbrados em companhias brasileiras: (i) obtenção de vantagens desproporcionais na consecução das atividades da sociedade sob controle, por exemplo, por meio da determinação do fluxo de dividendos; (ii) negociação direta em operações de alienação de controle, com possibilidade de pagamento de prêmio de controle; e (iii) realização de operações que resultem na diluição dos demais acionistas (freeze out).

$\mathrm{Na}$ prática, nota-se que, mesmo após relevantes mudanças no mercado acionário brasileiro, ainda existem meios vantajosos de extração de benefícios particulares pelos acionistas controladores de companhias brasileiras, de tal sorte que o número de companhias brasileiras com elevado grau de dispersão acionária ainda está distante de ser tão expressivo quanto o identificado no mercado norte-americano, por exemplo.

A origem familiar das sociedades por ações brasileiras e a cultura pela manutenção do poder de controle ainda representam grandes barreiras a uma efetiva migração da estrutura de capital concentrado, predominante no País, para uma estrutura de capital disperso. É inegável que o controle majoritário e o caráter familiar permanecem intrínsecos à estrutura da maioria das companhias brasileiras.

Em contraponto, o mercado de capitais brasileiro vivencia uma fase de amadurecimento e consolidação que inclui o aumento do volume e da complexidade das operações, bem como maior profissionalização de seus agentes. Identifica-se, por conseguinte, uma sensível mudança na estrutura de capital das companhias brasileiras, que força certa ruptura do originário modelo de propriedade de capital extremamente concentrada rumo a um modelo de propriedade de capital com maior dispersão.

Ora, no que se refere à estrutura da propriedade acionária, o Brasil encontra-se em um momento de contradição entre as expectativas do mercado, os esforços da regulação e a 
realidade prática das companhias abertas. Embora seja possível notar, no âmbito nacional, uma crescente tendência à abertura do capital de companhias de pequeno e médio portes, assim como à pulverização do controle das companhias abertas de maior porte, as estruturas de controle concentrado persistem no País, tanto que os níveis de dispersão acionária identificados atualmente no Brasil estão muito distantes dos níveis da realidade, por exemplo, das companhias norte-americanas.

De forma completamente diversa da estrutura identificada no Brasil (hoje e na mesma época), Berle e Means (1968) constataram empiricamente que, em 1929, níveis de dispersão acionária extremamente relevantes podiam ser identificados nas companhias abertas dos Estados Unidos. A exemplo, dentre as maiores companhias norte-americanas de capital aberto, as empresas Pennsylvania Railroad (setor ferroviário); United States Steel Corporation (setor industrial); e American Telephone and Telegraph Company (setor de infraestrutura) tinham nível de dispersão de capital tão elevado que não existia sequer um acionista que detivesse participação superior a $1 \%$ do capital social, as maiores participações acionárias nessas companhias correspondiam, respectivamente, a 0,34\%, $0,70 \%$ e $0,90 \%$ do capital social.

Vale lembrar que a evolução histórica do Brasil em muito influenciou para a concentração do capital, seja por particulares visando à manutenção de uma estrutura familiar seja pelo próprio Estado, de tal modo que a própria interpretação legal do conceito de controle acionário foi construída sob a ótica do controle interno majoritário.

Mister se faz, portanto, identificar a real estrutura de propriedade do capital das companhias abertas brasileiras, que, atualmente, habitam um cenário de contraste, no qual tudo parece favorecer à dispersão acionária, enquanto os acionistas relutam em manteremse titulares do controle sobre as atividades sociais.

Segundo Moraes (2006, p. 51):

[o] movimento de dispersão acionária contrasta com o de concentração de ações,
que caracteriza as empresas brasileiras, ou seja, de consolidação do poder num
acionista ou grupo controlador. É uma evolução no sentido da real
democratização do capital das empresas, que vem sendo preconizado e
estimulado há mais de trinta anos e que já é realidade em muitos países.

É exatamente nesse ambiente de contraste entre realidade dispersa versus histórico concentrado em que será desenvolvido o presente trabalho. À luz de questões históricas e culturais do País e da tradicional interpretação legal do conceito de controle acionário 
como controle interno majoritário, este estudo é elaborado com o objetivo principal de desmistificar a dinâmica da propriedade acionária das companhias abertas brasileiras, em especial as listadas no Novo Mercado, de modo a identificar a existência do controle minoritário em companhias listadas no referido segmento especial de governança corporativa.

Os reflexos do movimento de dispersão acionária observado nos últimos anos ganham destaque no presente estudo em face da histórica construção legal do conceito de controle societário como controle interno majoritário, sem que houvesse, na prática, uma preocupação com a possível configuração de um controle minoritário.

Nesse contexto, extensa pesquisa empírica foi realizada com o propósito de verificar os reais efeitos do recente fenômeno de dispersão acionária sobre as companhias brasileiras e evidenciar a ocorrência de novas configurações no perfil do poder de controle nas companhias listadas no Novo Mercado.

De modo a evidenciar empiricamente a existência de companhias sem controle detido por maioria do capital votante, a referida pesquisa é realizada como instrumento para a identificação de elementos que possam favorecer a configuração de um acionista ou grupo de acionistas como detentores do controle societário interno, ainda que sejam detentores de participação societária inferior à maioria do capital social votante.

Conforme excelente estudo realizado por Comparato e Salomão Filho (2005, p. 29), o vernáculo controle, originado de vocábulo francês e sob influência da língua inglesa em sua evolução semântica, pode ser entendido sob a ótica da língua francesa, no sentido de fiscalização, ou, ainda, de poder ou dominação, na perspectiva da língua inglesa. A partir do vocábulo controle, três acepções fundamentais devem ser depreendidas: (i) investigação, (ii) censura e (iii) exercício de poder decisório, com objetivo de dominar ou regular as ações de terceiro.

Nesse sentido, concluem os autores (2005, pp. X, XVII):

\footnotetext{
o controle é, pois, a prerrogativa possuída pelo titular de um poder superior de impor suas decisões sobre o titular de um poder inferior [...], controle é o poder jurídico moderno, próprio das sociedades ou organizações complexas, nas quais se manifesta necessariamente uma hierarquização de funções.
}

Dessa forma, para fins da presente dissertação, destaca-se que a palavra controle será empregada e estudada no âmbito das sociedades por ações, sob a acepção de poder- 
dominação. Ressalta-se, ainda, que esta pesquisa será dirigida para a análise do controle exercido por aquele que participa internamente na sociedade (controle interno).

A primeira impressão de controle interno, com base na acepção de poderdominação na condução das atividades sociais e na noção de soberania da assembleia geral, pode tender ao entendimento de que este se configuraria apenas na hipótese de titularidade de maioria do capital social votante. No entanto, a experiência jurídico e econômica vivenciada pelas grandes companhias, em especial as norte-americanas, demonstrou realidade diversa, sendo possível identificar companhias cujo controle societário interno poderia ser exercido por um acionista minoritário, quando este for detentor, por exemplo, da maior participação em companhia cujas ações estejam altamente dispersas no mercado (PEREIRA, 1995, pp. 12-13).

É justamente nesse contexto em que se faz relevante a discussão ora proposta e, em especial, a pesquisa empírica realizada. A partir do reconhecimento dos reflexos do fenômeno de dispersão vivenciado nos últimos anos sobre a propriedade acionária das companhias brasileiras de capital aberto, buscar-se-á comprovar a existência do controle minoritário nas companhias listadas no Novo Mercado, bem como avaliar, em segundo momento, os reflexos dessa constatação, tendo em vista a divisão da doutrina e da própria CVM sobre a existência de um controle societário interno exercido por acionista ou grupo de acionistas não detentores da maioria do capital social votante.

Embora possa haver certa oposição ao uso da expressão "controle minoritário" tal como empregado na presente dissertação, por sua eventual alusão a um acionista minoritário enquanto na realidade o controle seria exercido por acionista ou grupo que se compôs majoritariamente nas assembleias gerais, entende-se que o mesmo ocorre com relação ao uso das expressões acionista majoritário e controle majoritário ${ }^{5}$. Partindo-se da noção, conforme raciocínio demonstrado adiante, de que o controle societário é controle de fato, entende-se que o uso da palavra controle ligada ao termo minoritário já faz por si só alusão a minoria do capital social votante que faz prevalecer sua vontade nas deliberações em assembleia geral tornando-se, por consequência, maioria no conclave social. Portanto para fins do presente trabalho, referir-se-á ao instituto do controle exercido pela minoria do capital social votante tanto como controle minoritário ou controle não majoritário.

\footnotetext{
${ }^{5}$ Concorda com tal acepção Oioli (2011, p. 319), que propõe o emprego da expressão "controle diluído".
} 
Com relação ao desenvolvimento deste estudo, apenas com relação às companhias brasileiras emissoras de valores mobiliários listadas no segmento especial do Novo Mercado, destaca-se que tal delimitação se deve (i) à grande quantidade de companhias listadas no Novo Mercado, em relação aos demais níveis de governança corporativa da BM\&FBOVESPA, e (ii) ao fato de essas companhias possuírem o capital social dividido apenas em ações ordinárias, sendo atribuído a todos os acionistas o direito de voto, o que pressupõe maior dispersão acionária e garante maior credibilidade à pesquisa empírica realizada com base na participação societária detida pelos maiores acionistas de tais companhias, tendo em vista que a totalidade do capital social corresponderá, necessariamente, à totalidade do capital votante.

Sobre o último aspecto apresentado acima, vale mencionar a constatação obtida por Gorga (2008, p. 27), ao discorrer sobre a estrutura de capital das companhias brasileiras listadas na BM\&FBOVESPA: "The data on direct ownership confirm that dispersion is found mostly in Novo Mercado, where the one-share-one-vote requirement promotes a broader diffusion of voting rights".

Por fim, conforme detalhado no Capítulo 3 do presente estudo, ressalta-se que a pesquisa empírica proposta foi realizada sobre amostra do total de companhias listadas no Novo Mercado, cujo registro no segmento tenha sido realizado até 31 de maio de 2013, uma vez que as principais informações objeto de análise foram apuradas com base nos dados divulgados por tais companhias em seus respectivos Formulários Cadastrais e de Referência, atualizados até a mesma data de corte, em cumprimento ao exigido pela legislação aplicável. Desse modo, as informações analisadas possuem, em regra, data-base de 31 de dezembro de 2012, exceto por eventuais informações que tenham sido atualizadas até 31 de maio de 2013, em função da ocorrência de determinado evento que gerasse a necessidade de atualização do respectivo formulário nos termos da legislação aplicável.

\subsection{Plano da Dissertação}

A estrutura e o desenvolvimento da pesquisa objeto do presente trabalho giram em torno da crescente dispersão de ações entre os investidores de companhias abertas brasileiras, em especial aquelas listadas no segmento especial do Novo Mercado da 
BM\&FBOVESPA, vis a vis a forte cultura de concentração acionária até então predominante no mercado de capitais brasileiro.

Em sua fase inicial, a presente dissertação apresentará noções introdutórias sobre as diferentes estruturas de propriedade acionária identificadas nas principais economias, quais sejam estruturas de capital disperso e de capital concentrado, sendo analisada a importância do reconhecimento de limites à utilização de tais definições teóricas, bem como da atribuição de certa dinamicidade na adoção de determinada estrutura pelas companhias abertas, conforme se verificará na leitura da primeira parte do Capítulo 2, a seguir.

Uma vez conhecidas as tendências do Direito Comparado sobre a estrutura de propriedade acionária das sociedades por ações de capital aberto, a segunda parte do Capítulo 2 destacará a importância do tema no cenário brasileiro e apresentará uma breve retrospectiva da propriedade acionária nas companhias abertas brasileiras, de modo a verificar as características do mercado acionário brasileiro vis a vis as lições trazidas pelo Direito Comparado.

A partir do reconhecimento de um cenário contrastante, de mudanças no perfil do poder de controle sobre as companhias brasileiras em conflito com a histórica concentração acionária, será apresentada, ainda, breve análise sobre a chamada estrutura de capital pulverizado, sendo consideradas, para tanto, características histórico-societárias das companhias abertas brasileiras, tal como identificadas na retrospectiva proposta no mesmo capítulo.

Nesse contexto, com o objetivo de demonstrar a existência do controle societário minoritário entre as companhias listadas no especial do Novo Mercado, decorrente das mudanças na propriedade acionária apresentadas no capítulo anterior, a terceira parte do presente estudo descreverá extensa pesquisa empírica realizada mediante levantamento de dados e informações divulgados por tais companhias à CVM, conforme detalhados nos apêndices deste trabalho. Dessa forma, são demonstrados a atual estrutura de propriedade acionária predominante entre as companhias brasileiras listadas no referido segmento e os expedientes utilizados por alguns acionistas como artifícios de entrincheiramento para a sua perpetuação no comando das atividades sociais.

Observados os resultados da pesquisa, o capítulo quarto revisitará o conceito de controle societário sob a ótica da Lei das S.A., tendo em vista a divisão identificada na 
doutrina e em julgados da CVM, no âmbito da existência de um controle societário exercido por acionista ou grupo de acionistas não majoritário. Dessa forma, com base nos elementos apurados no terceiro capítulo, será traçado um paralelo entre a definição de controle societário, constante da Lei das S.A., a posição da doutrina sobre o tema e a consequente possibilidade de reconhecimento da existência de controle minoritário nas companhias brasileiras, em especial aquelas listadas no Novo Mercado.

Para tanto, de modo a contribuir para o conhecimento geral sobre o tema e a própria imputação de deveres e responsabilidades a esse acionista titular do poder de controle, nos termos da Lei das S.A., o capítulo quarto da presente dissertação será dividido em quatro partes dedicadas (i) ao resgate dos conceito de controle societário vis a vis a realidade da propriedade acionária no Brasil, (ii) ao levantamento de precedentes na CVM que evidenciem a importância da reflexão sobre o tema como realidade latente das companhias listadas no Novo Mercado, (iii) à análise dos requisitos legais necessários para a configuração do controle societário, e (iv) à busca de requisitos complementares que possam contribuir para a efetiva identificação do acionista controlador titular de participação não majoritária.

Por fim, no quinto e último capítulo desta dissertação, serão apresentadas as principais conclusões obtidas no curso da elaboração do estudo e considerações finais sobre a análise aqui proposta, com destaque ao reconhecimento da existência de controle minoritário em companhias listadas no Novo Mercado.

Diante da divergência doutrinária sobre o instituto do controle minoritário e da ausência de posicionamento claro da CVM sobre o tema, espera-se que a comprovação empírica da existência dessa espécie de controle entre as companhias abertas brasileiras listadas no Novo Mercado possa conferir a atenção devida a esse importante desafio do direito societário atual, contribuindo, de certa forma, para uma aplicação justa e eficiente do direito societário pátrio. 


\section{CAPÍTULO 2 \\ PROPRIEDADE ACIONÁRIA}

\subsection{Tendências}

Muito se discute sobre a estrutura organizacional capaz de proporcionar maior eficiência ao desenvolvimento de uma companhia aberta e, consequentemente, ao mercado de capitais no qual ela se insere. Nesse contexto, surgem inúmeros questionamentos sobre as diferentes estruturas de propriedade acionária identificadas nas principais economias.

Durante aula ministrada na Faculdade de Direito de Porto Alegre, em outubro de 1944, Ascarelli (2005, p. 108 e ss.) alertou seus ouvintes sobre a tendência de duas realidades distintas verificadas na prática societária, em decorrência da evolução das sociedades por ações: de um lado, a sociedade anônima resultante da ideia de patrimônio separado, constituída por único ou poucos sócios, familiares em sua maioria, e predominante nos países cujo desenvolvimento industrial encontrava-se em estágio inicial; de outro, as sociedades com grande dispersão acionária, decorrentes da tendência de colocação de ações ao público e presentes nos países em que o mercado de capitais seria mais desenvolvido.

Consagrada nos dias atuais, a referida problemática implicou duas formas de composição acionária claramente identificadas em diferentes economias: (i) estruturas de propriedade acionária concentrada, nas quais, ainda que em diferentes graus de intensidade, o capital social concentra-se nas mãos de acionista ou grupo de acionistas que exercem diretamente o poder de controle sobre as atividades sociais, estando estes organizados, na maioria dos casos, por meio da titularidade de participação superior à maioria do capital votante; e (ii) estruturas de propriedade acionária dispersa, nas quais a dispersão das ações no mercado é identificada em intensidade suficiente para que a figura de um acionista controlador, detentor da maioria do capital social votante, seja inexistente; em consequência, a conhecida minoria acionária restaria multiplicada em medida 
suficiente para transformar-se na maioria da base acionária, ainda que sem a titularidade do poder de controle.

Predominante em grandes economias, como Estados Unidos e Inglaterra, a estrutura da dispersão da propriedade acionária surgiu em decorrência de diversos fatores, principalmente econômicos, que favoreceram a consolidação de companhias de grande porte e com elevado número de acionistas.

Com base em extensa pesquisa de Direito Comparado, Penteado (2005) analisou os referidos fatores. Sob a ótica da experiência norte-americana, o autor demonstra a disseminação da estrutura da propriedade acionária dispersa em decorrência dos seguintes fatores: (i) o papel dos bancos de investimento no financiamento da produção em larga escala e as altas demandas financeiras para a construção de ferrovias e redes telefônicas, que favoreceram a necessidade de fontes alternativas de capitalização, bem como resultaram na profissionalização da administração, mediante nomeação de representantes das fontes de financiamento; (ii) a forte atuação da bolsa de valores de Nova Iorque (New York Stock Exchange - NYSE), que, em resposta à ausência de regulação sobre a proteção de pequenos investidores, atuou fortemente na defesa de seus interesses; (iii) a forte regulação sobre as instituições financeiras, que limitava o exercício de atividades envolvendo o investimento em ações de companhias listadas; e (iv) o grande movimento de fusões e aquisições, no período entre 1895 e 1903, posto que, na maioria das vezes, essas operações não contemplavam pagamentos em espécie, mas a simples permuta de ações entre a companhia original e outra (incorporadora ou nova companhia decorrente de fusão) (PENTEADO, 2005, p. 35 e ss.).

Coffee (2001) justifica o referido aquecimento das operações de fusões e aquisições nos Estados Unidos e o expressivo aumento na base acionária das companhias norteamericanas como resultantes do Sherman Antitrust Act, de 1890. Por meio do referido ato, o regulador norte-americano buscou garantir melhor igualdade de condições à concorrência, evitando a formação de cartéis entre empresas concorrentes, sem, no entanto, proibir diretamente a consolidação de empresas por meio de fusões e aquisições.

Nesse sentido, ressalta Coffee (2001, p. 33):

But if cartels of conspiring firms were forbidden, competitors could instead employ mergers to create monopolies - at least until this was later also prohibited: In any event, the Sherman Act triggered a wave of horizontal mergers among competitors that, in the process, also diluted existing block holders and thereby created dispersed ownership. The 
classic example was the consolidation of some eight competing steel companies into a new firm, U.S. Steel, in 1901. The transaction was engineered by J.P. Morgan and created the largest business corporation in the world. A transaction on such a scale inherently created dispersed ownership, even if each of the corporate participants previously had concentrated ownership, and it also produced a new firm with so heightened a capitalization that it was simply beyond the ambitions of any potential raider, thus making dispersed ownership stable.

No que se refere à disseminação da estrutura de propriedade dispersa entre as companhias inglesas, não foi identificado movimento histórico de fusões e aquisições tão expressivo que pudesse justificar a ampliação da base acionária dessas companhias. No entanto, Penteado (2005, p. 43 e ss.) salienta dois importantes fatores como originários desse movimento: (i) a ausência de interação entre as instituições financeiras e as companhias inglesas, de modo que, tal como na experiência norte-americana, por falta dos aportes financeiros necessários por parte dos bancos comerciais, por empréstimos ou investimentos diretos via aquisição de ações, as companhias inglesas se viram forçadas a buscar fontes alternativas de financiamento; e (ii) a evolução do mercado de capitais inglês, decorrente dos reflexos da revolução industrial e da referida necessidade de captação de recursos pelas companhias inglesas via este mercado, de modo forma que, diferentemente da experiência norte-americana, não possuía regras tão rigorosas para a concessão do registro de companhia aberta, facilitando o acesso ao mercado.

Ainda que os estágios de dispersão acionária das companhias norte-americanas e inglesas tenham sido atingidos em momentos e condições diferentes, em ambas as nações predominam companhias cujo capital social encontra-se disperso no mercado em tal intensidade que a figura de um acionista controlador, que seja detentor da maioria do capital social votante, é inexistente, possibilitando, na maior parte dos casos, o exercício do poder de controle pela própria administração da companhia.

Na clássica obra de Berle e Means (1968), ao avaliarem o cenário vigente nos Estados Unidos, em 1929, os autores identificaram companhias cujo capital encontrava-se altamente disperso entre seus pequenos acionistas e, por não haver acionista detentor de participação acionária relevante, o controle sobre as atividades dessas companhias (modern corporations) restava concentrado nas mãos de seus respectivos administradores, sob o então denominado controle gerencial. 
Conforme analisado por Bertoldi (2000, p. 63):

o controle gerencial se faz sentir quando se verifica o controle interno totalmente desligado da titularidade das ações em que se divide o capital social, controle este oriundo da extrema dispersão do capital social, fazendo com que os administradores assumam o controle empresarial de fato, enquanto que os acionistas exercem a função de meros prestadores de capital.

No âmbito da constatação de existência do controle gerencial, Berle e Means (1968, p. 6) ressaltam, ao desenvolverem a famosa teoria da segregação entre a propriedade do capital e o controle exercido sobre a condução dos negócios sociais:

Separation of ownership and control becomes almost complete when not even a
substantial minority interest exists, as in the American Telephone and Telegraph
Company whose largest holder is reported to own less than one per cent of the
company's stock. Under such conditions control may be held by the directors or
titular managers who can employ the proxy machinery to become a self-
perpetuating body, even though as a group they own but a small fraction of the
stock outstanding.

Nos mercados em que prevalece a propriedade acionária dispersa, o problema central enfrentado pela legislação societária recai sob a regulação do conflito existente entre os administradores de uma companhia e seus acionistas. Definido pela doutrina norte-americana como agency problems, vale citar esclarecimento apresentado por Hansmann e Kraakman (2006, p. 21) sobre o conflito de agência: "For readers unfamiliar with the jargon of economists, an 'agency problem' - in the most general sense of the term - arises whenever the welfare of one party, termed the 'principal', depends upon actions taken by another party, termed the 'agent'."

Conforme demonstrado por Gilson e Gordon (2003, pp. 2-4), a disciplina dos mercados de capitais, no âmbito das companhias com estrutura dispersa, resta destinada à imposição de deveres fiduciários e o estabelecimento de incentivos suficientes para alinhar os interesses diversos entre administradores e acionistas. Para tanto, são criados mecanismos de monitoramento dos administradores pelos acionistas, a fim de garantir que aqueles conduzam as atividades sociais de acordo com o interesse dos acionistas, preservando o retorno de seus investimentos.

Nesse contexto, ao voltarmos a perspectiva do presente estudo aos sistemas em que prevalecem as estruturas de propriedade acionária concentrada, a problemática central recai sobre o monitoramento da extração de benefícios privados pelo acionista controlador, em detrimento dos acionistas titulares de participação não controladora, tendo em vista que 
o controle societário e a condução dos negócios sociais restam intrinsicamente ligados em um cenário de concentração acionária.

Predominante em países da Europa, Ásia e América Latina, as estruturas com composição acionária concentrada direcionam o foco da legislação dessas nações para a limitação do poder do controlador e sua capacidade de extrair elevados benefícios privados sobre tal posição, em detrimento dos interesses dos demais acionistas da companhia em questão. Sob uma visão macro, conforme demonstrado por La Porta et al. (1998), países com baixa proteção conferida aos interesses e direitos dos acionistas minoritários tendem a favorecer a presença de um acionista controlador (geralmente grupo familiar ou o próprio estado). Por conseguinte, o mercado de capitais seria mais desenvolvido e as ações negociadas teriam maior valor agregado nas economias cujo sistema legal conceda maior proteção aos acionistas minoritários.

Como se pode depreender dos elementos apresentados até o momento, embora tanto a estrutura de capital concentrado como a de capital disperso apresentem conflitos decorrentes da extração de benefícios privados por um agente (acionistas controladores e administradores, respectivamente), a doutrina em geral tende a defender um engrandecimento das estruturas de capital disperso que, tidas como requisito para o desenvolvimento do mercado de capitais, acabam sendo consideradas como um estágio de evolução mais qualificado do que aquele em que se encontram as estruturas de capital concentrado.

La Porta et al. (1998), ao analisarem a tendência da propriedade acionária das grandes companhias de 27 países classificados como as nações mais ricas, apuraram empiricamente os acionistas controladores finais de cada uma das companhias objeto de estudo e, ao final, reconheceram que a realidade de dispersão acionária defendida por Berle e Means (1968), e consagrada na literatura financeira, não deveria, necessariamente, ser aplicável à realidade de todos os países.

Os resultados apurados demonstraram que o conceito de grandes companhias consolidadas em um ambiente de capital extremamente disperso seria comum apenas nos países mais ricos e desenvolvidos, disciplinados pelo common law, enquanto países ainda em desenvolvimento, com pobre proteção acionária, tenderiam a possuir estruturas de propriedade acionária concentrada, nas quais, mesmo que no âmbito de suas maiores companhias, haveria a predominância da figura de um acionista controlador que corresponderia, na maioria das vezes, ao acionista fundador e/ou seus descendentes. 
Na mesma linha, Comparato e Salomão Filho (2007, p. 110) defendem expressamente a adoção de modelos de propriedade dispersa:

[...] estruturas de controle diluído são preferíveis, pois contribuem para a democracia acionária e, em última instância, social. Além disso, como recentes estudos têm demonstrado, existe uma relação inversa entre grande concentração e valor de mercado da companhia, o que demonstra que também para a capitalização das empresas e o desenvolvimento do mercado de capitais a diluição acionária é fundamental.

Diferentemente do histórico ambiente favorável ao desenvolvimento do mercado de capitais, tal como descrito para as nações norte-americanas e inglesas, países como Brasil, Alemanha, Itália e Japão vivenciaram realidade diversa. Em geral, ainda que sob diferentes graus de concentração, o desenvolvimento das referidas nações contou com forte atuação do Estado e/ou dos bancos como fontes de captação financeira das grandes companhias, o que restou por favorecer o forte domínio desses credores sobre a condução das atividades sociais e a inviabilidade da dispersão das respectivas participações ao público.

Nas referidas economias, como bem apontado por Penteado (2005, p. 61-62.), as companhias não fazem uso da poupança popular como meio de financiamento de grande parte das atividades sociais, uma vez que o financiamento necessário para tanto é atendido mediante o recebimento de empréstimos ou investimentos diretos, realizados por seus acionistas fundadores, por instituições financeiras (principalmente nos casos das companhias alemãs e japonesas), ou, ainda, pelo próprio Estado (como na experiência italiana).

Nota-se, portanto, que a realidade socioeconômica das nações nas quais predominam as estruturas de propriedade acionária concentrada acabou por não favorecer o aquecimento de seus mercados de capitais em níveis tão elevados como os constatados em nações como Estados Unidos e Inglaterra. Dessa forma, após a análise da origem e das características estruturais de propriedade acionária concentrada e dispersa, permanece o questionamento sobre a qualificação de uma estrutura como melhor do que a outra.

A tese de Berle e Means (1968) sobre a dissociação do poder de controle da propriedade acionária em decorrência da dispersão acionária foi largamente divulgada e por gerações serviu de base para inúmeros pesquisadores dos campos jurídico e econômico, que acabavam por considerar incontestável a teoria da dissociação entre controle e propriedade, favorecendo a interpretação de que a estrutura de dispersão 
acionária deveria ser adotada como tendência de estágio final a ser alcançado por todas as companhias nas diferentes nações, conforme já mencionado.

No entanto, entre as décadas de 1970 e 1990, foram publicados diversos estudos que questionavam empiricamente a assertiva acima. Ao demonstrarem a concentração de capital ainda existente em algumas companhias norte-americanas e ao evidenciarem que estruturas de capital concentrado ainda eram predominantes em companhias de outros países, a tendência de migração de sistemas foi colocada em xeque ${ }^{6}$. Ora, a predominância do controle concentrado em algumas nações leva ao questionamento sobre a real necessidade de transformação da estrutura de propriedade acionária concentrada para uma estrutura de propriedade dispersa.

Em busca de alternativas à interpretação de obrigatoriedade de migração de uma estrutura de propriedade concentrada rumo à estrutura dispersa, que representaria melhor estágio de desenvolvimento do direito societário e do mercado de capitais local, surgem estudos sobre a possibilidade de convergência das diferentes estruturas de propriedade acionária, tendo em vista as vantagens e desvantagens existentes em cada uma, inclusive no que se refere à possibilidade de preferência do acionista por uma em detrimento da outra, em face das diferentes alternativas de extração de benefícios.

Nesse contexto, Roe e Bebchuk (1999) e La Porta et al. (1997) ressaltam a importância de reconhecer elementos culturais, sociais, históricos e políticos intrínsecos a uma determinada economia antes de estabelecer a adoção de uma única estrutura de propriedade do capital como a mais adequada.

Sobre o tema, afirma Munhoz (2009, p. 153):

A transformação da estrutura de controle dominante em um determinado país não se faz apenas por meio da modificação das regras societárias [...]. Há uma série de outros fatores, de ordem econômica, social e política, que tornam a estrutura de controle presente em um dado momento histórico altamente resistente a mudanças [...]. Diante desse quadro, a tarefa do estudioso do direito societário, antes de buscar a transformação do sistema, deve ser a de tornar a lei societária aplicável à estrutura atual o mais eficiente possível [...].

\footnotetext{
${ }^{6}$ Dos referidos estudos, diversos foram levantados por La Porta et al. (1998, p. 2-3), entre os quais vale mencionar: (i) EISENBERG, Melvin. The structure of the corporation: a legal analysis. Little, Brown and Co., Boston, MA, 1976.; (ii) FRANKS, Julian, MAYER, Colin. The ownership and control of German corporations. Manuscript, London Business School, 1994; (iii) BARCA, Fabrizio. On corporate governance in Italy: issues, facts, and agency. Manuscript, Bank of Italy, Rome, 1995; e (iv) PROWSE, Stephen. The structure of corporate ownership in Japan. Journal of Finance, v. 47, pp.1121-1140, 1992.
} 
A realidade é de que não há um sistema melhor do que outro, mas sim eficientes ou ineficientes, de acordo com as características do meio em que a companhia opera, devendo o legislador, em qualquer dos casos, atentar para a redução dos conflitos de agência, em prol de maior segurança e confiabilidade nas condução das operações sociais.

Conforme detalhado por Gilson e Gordon (2003), a escolha da estrutura mais eficiente deve ser dinâmica, de modo que a ela estejam atreladas as possibilidades existentes diante dos custos decorrentes da manutenção e extração de benefícios privados pelos acionistas controladores (private benefits of control) versus os custos incorridos para manutenção e monitoramento dos administradores em um ambiente de capital altamente disperso (agency problems).

Na análise do Direito Comparado, nota-se que, como já destacado e examinado por Penteado (2005, p. 62), a consolidação de estruturas de propriedade acionária dispersa em detrimento de estruturas de capital concentrado, e vice-versa, está diretamente relacionada ao mecanismo adotado para o desenvolvimento das companhias abertas.

Enquanto é possível identificar companhias que se viram forçadas a buscar financiamento junto à poupança popular, como no caso das norte-americanas e inglesas, verifica-se, também, outras às quais foram oferecidas alternativas de capitalização, como nos citados casos de Japão, Alemanha e Itália, para os quais não foram necessários esforços tão expressivos para a capitalização via mercado de capitais, já que investimentos diretos por aumentos de capital e/ou financiamentos concedidos pelo governo, instituições financeiras e acionistas diretos (grupos familiares), atendiam, em grande parte, a demanda por recursos financeiros.

Na mesma linha, pode-se afirmar que a estrutura de propriedade do capital é uma resposta de equilíbrio ao ambiente legal em que as companhias operam. Conforme concluído por La Porta et al. (1998), no caso das economias de propriedade acionária concentrada, a melhoria no sistema de proteção dos acionistas minoritários representa uma concessão do acionista controlador ao acionista minoritário, de sorte que esta pode resultar ou não em dispersão do capital pelo então controlador, ao ponderar se tal medida lhe é atrativa sob a ótica de liquidez acionária versus a "livre" condução dos negócios sociais.

Ora, a adoção de determinada estrutura não deve ser definitiva, mas sim dinâmica, de modo que uma companhia deve ser constituída e administrada de acordo com a estrutura que melhor se adequar ao mercado e à economia em que ela se insere, cabendo ao 
aplicador do direito operar de forma a conferir maior segurança aos que se colocarem expostos ao risco de abuso por parte de seus respectivos agentes.

\subsection{A Propriedade Acionária nas Companhias Brasileiras}

La Porta et al. (1998), ao questionarem a assertiva de Berle e Means sobre o predomínio das grandes companhias norte-americanas com capital social altamente disperso no mercado, demonstraram a forte presença de estruturas de capital concentrado em determinados países, tendo sido empiricamente comprovada a baixa representatividade (e, em alguns casos, a própria ausência) de companhias sem um acionista controlador. $\mathrm{Na}$ referida pesquisa, os autores, entre outros critérios, presumiram titulares do controle societário, acionistas que detivessem participações diretas ou indiretas que somassem $20 \%$ e, alternativamente, $10 \%$ do capital social da companhia objeto de análise.

Referido estudou demonstrou que níveis de dispersão acionária, como os identificados nos Estados Unidos, estavam longe de ser atingidos por determinados países, entre eles, Argentina, Singapura, Áustria, Bélgica, Grécia, Israel, Itália e Portugal, nos quais, considerando o corte de acionistas detentores de participação acionária igual ou superior a $20 \%$ do capital social (tidos como acionistas controladores), a representatividade de companhias de capital disperso era inferior a $20 \%$ das companhias objeto da pesquisa realizada, sendo estas inexistentes, por exemplo, em economias como Argentina e México.

Tal como em outros países da Europa e América Latina, a propriedade acionária no cenário brasileiro se consolidou de forma extremamente concentrada. Ao analisarem a estrutura dos primeiros estatutos do Banco do Brasil, a qual estabelecia que apenas os 40 maiores acionistas portugueses da companhia poderiam constituir a assembleia geral, Comparato e Salomão Filho (2005, p. 38) reconhecem que, desde o século XIX, havia distinção entre acionistas titulares do poder de comando e meros investidores de capital de risco, realidade do poder mantida, mesmo após o surgimento da concepção da assembleia geral de acionistas como órgão soberano: 
Essa curiosa conjugação entre soberania da Assembléia Geral e realidade paralela do poder de controle decorre sem dúvida da ambigüidade supra ressaltada entre a característica aristocrática da grande companhia colonial e a natureza contratualista individualista da sociedade anónima pós-mercantilista. [...] A prática societária brasileira do século XIX e, de resto, toda a história societária brasileira que se seguiu são herdeiras dessa ambiguidade de fundo, que fortalece sobremaneira o poder do controlador.

De fato, a estrutura das sociedades por ações brasileiras se manteve eminentemente concentrada, de tal sorte que, mesmo na época da edição da antiga norma acionária (Decreto-Lei $\mathrm{n}^{\mathrm{o}}$ 2.627, de 26 de setembro de 1940), Trajano de Miranda Valverde reconheceu, na exposição de motivos do referido diploma legal, a origem familiar das grandes companhias brasileiras.

Com o advento da Lei das S.A. e da Lei $\mathrm{n}^{\mathrm{o}}$ 6.385, de 7 de dezembro de 1976, buscou-se impulsionar o mercado de capitais brasileiro como fonte alternativa para a captação de recursos pelas companhias, respeitado, porém, o caráter familiar e concentrado do exercício do poder de controle das companhias brasileiras.

Merecedor de estudo específico, essas breves considerações sobre o histórico das sociedades por ações no Brasil servem apenas para contextualizar as características e alterações identificadas na propriedade acionária das companhias brasileiras em face dos acontecimentos dos últimos anos. Nesse sentido, direciona-se o presente estudo à análise de dados empíricos que apontam a realidade prática da estrutura da propriedade acionária no Brasil.

Em 1987, Eizirik (1987) publicou inspirador artigo intitulado $O$ mito do controle gerencial - alguns dados empíricos, no qual demonstrou empiricamente que a tese de Berle e Means (1968) sobre a dissociação entre propriedade e controle era inadequada para o caso das companhias abertas brasileiras.

Com base no levantamento realizado pela Superintendência de Projetos e Estudos Econômicos da CVM, em 31 de janeiro de 1985, o artigo evidencia que, com relação à estrutura do controle de 456 companhias representativas de, aproximadamente, $90 \%$ do patrimônio líquido total das emissoras de valores mobiliários no Brasil: (i) não existiam companhias cujo principal acionista fosse detentor de participação inferior a $10 \%$ do capital votante, enquanto, por outro lado, na média das companhias analisadas, o acionista majoritário seria detentor de, aproximadamente, $70 \%$ das ações com direito a voto; (ii) em $18,64 \%$ das companhias, o controle era exercido mediante participações que variavam 
entre $90 \%$ a $100 \%$ do capital votante; e (iii) apenas em 15,13\% das companhias o controle seria exercido com menos do que $50 \%$ do capital votante.

A partir dos dados mencionados acima, conclui Eizirik (1987, p. 106):

\begin{abstract}
[...] o conceito de Cia. Aberta pouco ou nada tem a ver com a efetiva "abertura" (no sentido de democratização) do seu capital votante. Este permanece nas mãos do acionista controlador, no qual concentra-se o poder diretivo da companhia. A chamada "revolução dos gerentes" - tese visando demonstrar superioridade de um sistema que promoveria, privadamente, a progressiva "socialização" dos meios de produção pela via da dispersão acionária - entre nós não vingou.
\end{abstract}

No entanto, em consequência de diversos fatores histórico-econômicos, como (i) a abertura do mercado a investidores estrangeiros; (ii) a reforma econômica do período Fernando Henrique, que envolveu o surgimento do Plano Real e os processos de privatização; e (iii) a desregulamentação dos setores financeiros e do mercado de capitais nos Estados Unidos, aliada à globalização e à velocidade da informação na estruturação dos mercados, a existência de companhias com capital extremamente disperso ao público já é uma realidade no Brasil.

Ora, diante desses e de outros eventos que conferiram maior força ao movimento de dispersão acionária recentemente vivido no Brasil - valendo citar, ainda, (i) a criação dos segmentos especiais de governança corporativa; (ii) a reforma da Lei das S.A., por meio da Lei $\mathrm{n}^{\mathrm{o}} 10.303$, de 31 de outubro de 2001; e (iii) o boom de ofertas de ações primárias (IPOs), nos anos de 2006 e 2007 -, questiona-se a possibilidade de afirmar, aqui, que o entendimento de Eizirik (1987), defendido com tanta clareza ao final da década de 1980, permanece coerente nos dias de hoje.

Em outubro de 2001, Mckinsey \& Company e Korn/Ferry International divulgaram um estudo sobre a governança corporativa no Brasil, para o qual foram contatados 127 conselheiros, representantes de 74 empresas brasileiras com faturamento superior a US\$ 250 milhões. No que se refere às características de maior relevância do modelo de governança corporativa levantado à época da pesquisa, foi identificado que, na maioria das companhias analisadas, a estrutura de propriedade do capital era extremamente concentrada, sendo que $61 \%$ das ações ordinárias pertenciam, em média, a um único 
acionista e, quando considerados os três maiores acionistas, o percentual chegaria a $85 \%$ das ações ordinárias ${ }^{7}$.

Na mesma linha, um estudo publicado em 2003, pela Organização para a Cooperação e o Desenvolvimento Econômico (OCDE), apontou que 51\% das ações das 459 sociedades de capital aberto brasileiras pesquisadas eram detidas por um único acionista e $65 \%$ pelos três maiores acionistas ${ }^{8}$. Portanto, conforme destacado por Salomão Filho (2011, pp. 77-78), a estrutura de propriedade do capital nas empresas brasileiras ainda é caracterizada pelo controle familiar, compartilhado, ou exercido por multinacionais com acionistas minoritários pouco ativos e cujos interesses são pouco reconhecidos, havendo elevada sobreposição entre propriedade acionária e gestão executiva.

Estudo desenvolvido pelo coordenador do Centro de Estudos em Governança, Alexandre Di Micelli, divulgado pelo jornal Valor Econômico, em 19 de junho de 2009, demonstrou que, dentre a totalidade de ações listadas na bolsa de valores de São Paulo, apenas $1,3 \%$ das companhias representaria a classe de companhias com "capital pulverizado", enquanto 8,3\% corresponderiam àquelas com “controle minoritário" e 90,4\% com "controle definido". Independentemente do critério utilizado para a divisão dos grupos controle minoritário e controle definido, resta evidente a concentração acionária ainda presente no mercado de capitais brasileiro 9 .

Cabe citar, também, importante trabalho elaborado por Gorga (2008), para análise da estrutura de propriedade do capital das companhias brasileiras listadas na BM\&FBOVESPA, com base em dados de 2006 e 2007. Partindo do pressuposto de que companhias com controlador seriam aquelas com um único acionista detentor de mais de $50 \%$ do capital social votante, Gorga $(2008$, p. 27$)$ constatou, após análise da participação dos três maiores acionistas de 92 companhias listadas no Novo Mercado, a ausência de

\footnotetext{
${ }^{7}$ Panorama de Governança Corporativa do Brasil. Outubro de 2001. Disponível em: <http://www.ecgi.org/ codes/documents/kf_mck_governan.pdf>. Acesso em: 9 jul. 2012.

${ }^{8}$ Dentre as conclusões apresentadas no estudo, vale mencionar também que "duas claras características determinam as estruturas de controle e societárias da maioria das empresas latino-americanas: em primeiro lugar, essas sociedades apresentam uma participação acionária altamente concentrada [...]. A alta concentração acionária e a estrutura de conglomerado também afetam significativamente a composição do conselho de administração da sociedade. A maioria dos membros do conselho de administração das sociedades latino-americanas estão ligados aos controladores por meio de vínculos familiares, de amizade, relações comerciais e contratos de trabalho". In: ORGANIZAÇÃO PARA A COOPERAÇÃO E DESENVOLVIMENTO ECONÔMICO (OCDE). White paper on corporate governance in Latin America, 2003. p. 54. Disponível em: <http://www.oecd.org/dataoecd/49/50/24277169.pdf>. Acesso em: 5 jun. 2012.

${ }^{9}$ Dentre outras, são indicadas na referida matéria como companhias sob controle minoritário: Eternit, Cremer, Totvs, Bematech, Cia Hering, Dasa, ALL, Romi, Tempo Participações, Cyrela Realty, Metalfrio e BrasilAgro. In: A caminho da pulverização. Valor Econômico, 19 jun. 2009, Seção EU\&Investimentos, p. D1.
} 
acionistas controladores majoritários, na maioria das companhias analisadas. No entanto, reconhece a possibilidade de um controle compartilhado nas companhias em que a figura do controlador majoritário era ausente:

\begin{abstract}
[...] the majority of firms (sixty-five out of ninety-two) listed on Novo Mercado lack a controlling shareholder. In those sixty-five firms, the largest shareholder owns, on average, $26.23 \%$ of the shares, the three largest shareholders own $47.28 \%$ of the shares and the five largest own $54.73 \%$ of the shares. These results show two or three largest shareholders can coordinate their voting rights and control a corporation, even when the largest shareholder alone cannot. If those two or the tree largest shareholders belong to the same family, this formal agreement may not even be necessary. In the twenty-seven firms with a controlling shareholder, the largest shareholder on average owns $60.87 \%$ of the shares of the company. (grifo nosso).
\end{abstract}

Sob uma perspectiva mais recente, a KPMG no Brasil, em novembro de 2013, também divulgou interessante estudo com panorama atual da governança corporativa e do mercado de capitais no Brasil ${ }^{10}$. A partir da análise dos Formulários de Referência, divulgados no Sistema de Envio de Informações Periódicas e Eventuais (IPE) pelas 129 companhias listadas no Novo Mercado, na época do levantamento, demonstrou-se que 53\% das companhias analisadas possuíam controle majoritário ou compartilhado, enquanto, nos Níveis 1 e 2, a representatividade com esse tipo de controle subia para $90 \%$ e 94\%, respectivamente. A pesquisa detalhou ainda que a estrutura do controle identificado nas companhias encontra-se distribuída da seguinte forma: compartilhado (47\%); estatal (26\%); estrangeiro (17\%); familiar (7\%); e pulverizado $(3 \%)^{11}$.

Embora os trabalhos sobre a propriedade acionária das companhias brasileiras, ainda que recentes, evidenciem o predomínio de estruturas de capital concentrado, cuja propriedade acionária não favorece o exercício do controle societário por membros da administração, o movimento de dispersão acionária que contribuiu para o surgimento de companhias com capital altamente disperso no Brasil não pode ser desconsiderado pelos estudiosos do Direito Societário.

No momento em que as captações via mercado de capitais se mostraram mais atrativas para os acionistas controladores vis a vis a captação via mercado financeiro e/ou

\footnotetext{
10 Disponível em: <http://www.kpmg.com/BR/PT/Estudos_Analises/artigosepublicacoes/Documents/RiskCo nsulting/A-Governanca-Corporativa-e-o-Mercado-de-Capitais-13-14.pdf>. Acesso em: 20 nov. 2013.

${ }^{11} \mathrm{O}$ estudo elaborado pela KPMG no Brasil também apresenta interessante análise sobre a composição da administração das companhias listadas no Novo Mercado. Com base nas informações divulgadas no item 12.9 dos respectivos Formulários de Referência, no qual as companhias emissoras devem indicar se existem relações familiares de até segundo grau entre administradores e/ou membros do conselho, a pesquisa aponta que em 56\% das companhias listadas no Novo Mercado existem relações familiares dos membros do Conselho de Administração com outras pessoas da companhia ou com membros do próprio conselho.
} 
investimentos direto (por meio de aumentos de capital), muitos se renderam à alternativa de financiamento da companhia por mercado de capitais, o que resultou no movimento de dispersão acionária vivenciado na última década. Cumpre, portanto, reconhecer os reflexos desse relevante movimento de dispersão acionária sobre a estrutura de propriedade das companhias abertas brasileiras.

Quando se avaliam as razões que ensejam a abertura de capital e a adesão de companhias a níveis diferenciados de governança corporativa, tal como se identificou com maior intensidade nos últimos anos, destaca-se a necessidade de captação de recursos da poupança popular para fazer frente à necessidade financeira para condução das atividades sociais, conforme demonstrado anteriormente.

O acionista controlador, ao ponderar sobre a necessidade e conveniência da capitalização via abertura de capital e adesão a níveis diferenciados de governança corporativa, depara-se com a necessidade de reflexão, entre outros, sobre a eventual divisão de seu prêmio de controle. A prática societária demonstra que o acionista controlador ponderará se a concessão do direito de venda conjunta (tag along) e a adoção de uma série de melhores práticas de governança corporativa proporcionarão determinada redução na percepção de risco do negócio e a um incremento das possibilidades de acesso a fontes de financiamento e de expansão suficientes a ponto de que, quando efetivada a venda de seu empreendimento, seja conferido valor superior ao atualmente atribuído a sua participação na companhia. Ou seja, partindo-se de uma estrutura de propriedade acionária concentrada, a matemática da tomada de decisão pela captação via mercado de capitais deve ser positiva ao acionista controlador.

Dessa forma, o acionista controlador considerará os benefícios de se sujeitar às regras de um segmento especial de governança, bem como os prejuízos de tal adesão, dentre eles: (i) a concessão do tag along, em caso de alienação do controle societário; (ii) as exigências e os custos superiores aos aplicáveis no segmento tradicional; e (iii) a obrigatoriedade de realização de oferta pública de ações a valor econômico, na hipótese de rescisão do contrato celebrado com a BM\&FBOVESPA.

Em um ambiente no qual são ponderados os benefícios extraídos de uma estrutura de propriedade acionária dispersa e os benefícios extraídos da manutenção de uma estrutura de propriedade acionária concentrada, o conflito entre acionistas controladores e não controladores merece atenção especial. Verifica-se que, a partir da maior atratividade das captações via mercado de capitais (vis a vis a captação via mercado financeiro), muitos 
acionistas controladores se rendem à alternativa de financiamento da companhia via mercado de capitais sem, no entanto, desfazerem-se do poder de controle, ou seja, a estrutura da propriedade acionária concentrada permanece.

Em meio a um ambiente favorável às captações via mercado de capitais, grande parte dos acionistas controladores opta por abrir o capital de sua companhia e dispersar parte de suas ações no mercado. Em contrapartida, com o objetivo de se manterem titulares do poder de controle, mesmo após o ingresso dos novos investidores, os acionistas então controladores arquitetam estruturas peculiares como, por exemplo, a celebração de acordos de acionistas e/ou inclusão de cláusulas que versem sobre as chamadas poison pills brasileiras nos estatutos sociais das respectivas companhias, tal como se pretende demonstrar empiricamente no Capítulo 3 da presente dissertação.

No contexto atual, é difícil antever se a perspectiva para as companhias abertas brasileiras deve se dar na condução de caminho rumo ao predomínio da estrutura de propriedade acionária dispersa, tal qual a identificada nos Estados Unidos; ou, se a tendência é de consolidação de uma estrutura híbrida, como a que se verifica nos dias atuais, podendo haver um aumento consolidado no número de companhias de capital disperso, mas sem redução significativa na quantidade de companhias de capital concentrado.

Conforme assinalado por Munhoz (2009), dentre os atuais desafios do Direito Societário, a estrutura de propriedade do capital permanece um importante aspecto a ser considerado quando da análise do mercado de capitais brasileiro. Nesse sentido, ainda que não se possa definir com certeza a tendência cabível às companhias brasileiras, cumpre aos estudiosos e operadores do Direito reconhecer a realidade societária do País e identificar elementos que permitam a adaptação da norma jurídico-societária ao ritmo de incremento das relações comerciais.

Conforme demonstrado no capítulo anterior, a literatura jurídico-societária classifica, em geral, a propriedade acionária como concentrada quando o controle acionário é exercido por acionista ou grupo de acionistas, e como dispersa quando ausente a figura do acionista controlador, abrindo-se espaço para o surgimento de uma administração titular do poder de controle, como demonstrado por Berle e Means (1968). De tal sorte, na primeira estrutura, surgem os custos de agência decorrentes do conflito entre acionistas controladores e acionistas minoritários, enquanto na segunda são identificados os famosos conflitos entre acionistas e administradores. 
Ocorre que, para fins do presente trabalho, a divisão acima, tal como proposta pelo Direito Comparado, mostra-se insuficiente, no âmbito da realidade das companhias abertas brasileiras.

Embora o movimento de dispersão acionária vivenciado nos últimos anos tenha quebrado o padrão histórico da propriedade acionária predominantemente concentrada, os índices de dispersão acionária identificados no Brasil ainda estão longe de atingir os níveis observados nos Estados Unidos e Reino Unido, como já mencionado.

Ainda que existam companhias cujas ações se encontrem extremamente dispersas no mercado e nas quais a condução das atividades sociais resulte sob o domínio da administração, a cultura pela manutenção do poder de controle se mostra arraigada à realidade das companhias brasileiras. Por conseguinte, assim como comprovado pelos estudos citados, estruturas de propriedade acionária concentrada, tal qual classificadas pelo Direito Comparado, ainda são predominantes no País.

Ocorre que, se adotarmos integralmente a classificação da propriedade acionária, com base na titularidade do poder de controle por acionistas controladores ou por membros da administração da companhia, os reflexos do movimento de dispersão acionária gerados no mercado de capitais brasileiro, e consequentemente na estrutura das companhias abertas, seriam desconsiderados.

Conforme se pretende demonstrar no Capítulo 3, o referido movimento de dispersão favoreceu a manutenção do poder de controle nas mãos de acionista (ou grupo de acionistas) não necessariamente detentor da maioria do capital social votante, o que representou um relevante marco no desenvolvimento do mercado brasileiro, principalmente se considerada a histórica construção do conceito legal de controle societário interno, em volta da presunção desse controle como controle majoritário.

Dessa forma, ainda que organizada sob a forma de propriedade acionária controlada por acionista, a utilização do critério de controle detido por acionistas versus controle não definido ou detido por administradores representaria a junção de companhias com realidades completamente distintas sob um mesmo grupo. Explica-se: pela adoção do referido critério, embora seja possível segregar as companhias nas quais há predomínio sobre as atividades sociais exercido por acionista ou bloco controlador, tal critério não permite a diferenciação das companhias sob domínio do controle majoritário daquelas sob domínio do controle não majoritário, tido como controle minoritário. 
Em face da importância de reconhecimento do estágio híbrido em que se encontra o mercado de capitais brasileiro, no qual, em um ambiente de maior dispersão acionária, a figura do empresário-empreendedor, na maioria dos casos, ainda se sobrepõe à figura do simples investidor, entende-se ser igualmente importante o reconhecimento de diferentes graus de concentração do poder de controle sobre as atividades das companhias abertas brasileiras, como forma de conferir o devido destaque aos reflexos do fenômeno de dispersão acionária vivenciado pelo mercado de capitais brasileiro nos últimos anos.

Dessa forma, com o objetivo de favorecer o reconhecimento das principais características das estruturas de propriedade acionária identificadas nas companhias brasileiras, propõe-se, para o presente estudo, que haja uma divisão na tradicional classificação da propriedade acionária concentrada, de modo que sejam classificadas como companhias com estrutura acionária concentrada apenas aquelas nas quais exista um acionista (ou grupo de acionistas) detentor da maioria do capital social votante. Em contraponto, seriam classificadas como companhias com estrutura de propriedade dispersa todas as companhias brasileiras remanescentes, portanto, todas aquelas sem controle majoritário.

$\mathrm{Na}$ mesma linha, uma vez reconhecidas as características das estruturas de propriedade acionária concentrada e dispersa, e tendo sido segregadas as companhias com controle interno majoritário, propõe-se uma subdivisão na classe de companhias com propriedade acionária dispersa.

A divisão entre companhias de capital disperso se faz igualmente necessária tendo em vista a necessidade de distinguir as diferentes realidades existentes na atual configuração da propriedade acionária das companhias brasileiras, bem como o objetivo do presente estudo de identificar determinado nicho de companhias listadas no Novo Mercado, nas quais o controle minoritário poderia ser configurado.

Destaca-se que tal reflexão é proposta como meio de verificação de uma possível distinção entre as companhias nas quais o elevado grau de dispersão acionária pode resultar na titularidade do poder de controle por membros da administração, como demonstrado por Berle e Means (1968), e companhias nas quais, embora haja dispersão de parcela significativa do capital no mercado acionário, a titularidade do poder de controle remanesce concentrada nas mãos de acionistas organizados para a condução das atividades sociais, ainda que mediante a titularidade de participação acionária não representativa da maioria do capital social votante. 
Dessa forma, sob a ótica da realidade brasileira, entende-se que a subdivisão das companhias de capital disperso deve partir do uso da expressão "capital pulverizado", comumente utilizada para fazer referência a companhias que adotam a estrutura de propriedade do capital dispersa, sem qualquer distinção de companhias nas quais a figura de um acionista controlador seja inexistente.

Como comprovado no capítulo anterior, a propriedade acionária dispersa é concretizada em ambiente socioeconômico que favoreça a multiplicação da base acionária. Ocorre que a referida realidade deve considerar a possibilidade de uma relativa dispersão acionária que, apesar de resultar em diluição do acionista controlador suficiente para que uma companhia adote estrutura de capital dispersa, é insuficiente para que a propriedade do capital dessa companhia atinja nível de dispersão acionária capaz de conferir aos seus administradores o exercício do poder de controle.

Nesse contexto, propõe-se, no presente estudo, a adoção da expressão "companhia de capital pulverizado" como subclasse de companhias com propriedade acionária dispersa, de forma que estas sejam classificadas com base no grau de dispersão de suas ações no mercado em geral.

Defende-se que a referida classificação da propriedade acionária como "pulverizada" deve ser empregada apenas para as companhias cujo capital encontra-se extremamente disperso no mercado, ou seja, naquelas cujo controle societário interno, não definido, definitivamente não estaria concentrado nas mãos de um acionista ou grupo de acionistas, evidenciando-se um possível controle gerencial, decorrente do elevado grau de dispersão de suas ações. Seriam, portanto, pulverizadas as companhias com índices de dispersão acionária tão elevados como aqueles identificados nas companhias norteamericanas, nas quais é comum a distribuição da totalidade do capital social entre acionistas que detêm participação irrisória no capital social, conforme já citado ${ }^{12}$.

Nesse sentido, comentam Easterbrook e Fischel (1991, p. 82) sobre o controle gerencial e os pedidos públicos de procuração apresentados pela administração: "The modern corporation, according to Berle and Means, is characterized by omnipotent managers who, through control over the proxy machinery, keep themselves in office”.

\footnotetext{
12 Sobre a distinção ora apresentada, cita-se Penteado (2005, p. 20), que ao comparar as estruturas de propriedade acionária concentrada e dispersa, propõe que o percentual de $10 \%$ do capital social votante seria o melhor norte para distinguir tais estruturas, sendo que para fins do presente trabalho considerou-se que a estrutura por ele citada como dispersa corresponderia à estrutura de capital pulverizado: “[...] ou seja, caso uma companhia não possua um ou mais acionistas detentores de $10 \%$ ou mais do total das ações com direito de voto, sua estrutura acionária seria classificada como dispersa."
} 
Da mesma forma, as demais companhias sem controle majoritário, com níveis de dispersão acionária inferior ao identificado nas companhias com capital pulverizado, poderiam ser classificadas como companhias de capital relativamente pulverizado. Nessas companhias, embora haja dispersão acionária suficiente para a ausência de acionista (ou grupo de acionistas) detentor da maioria do capital votante, a referida dispersão ainda permite a consolidação do poder de controle por acionista ou bloco de acionistas controladores.

Nesse contexto, vale citar a rara distinção feita na literatura jurídico-societária proposta por Munhoz (2010, p. 303). Ao considerar os diferentes graus de dispersão acionária presentes entre companhias de capital disperso, o autor reconhece a existência de companhias de capital disperso compostas por acionistas incapazes de exercer poder sobre a administração que seja suficiente para a condução das atividades sociais, classificando, em contrapartida, como companhias de capital relativamente pulverizado aquelas que:

\begin{abstract}
apresentam determinado grau de dispersão, mas que se caracterizam pela presença de acionistas que, pela titularidade de parcelas significativas do capital, têm capacidade de atuar (individualmente ou em conjunto) de forma ativa e decisiva nas decisões empresariais. É o caso clássico das companhias com controle minoritário. Também incluem-se nessa classificação, porém, companhias sem controlador [...], mas compostas por grupos atuantes de acionistas, capazes de influenciar de modo relevante a administração.
\end{abstract}

Sobre o tema, cita-se, ainda, proposta de distinção apresentada por Silveira (2010, p. $183^{13}$ apud Munhoz 2012, p. 184), que ao realizar levantamento sobre a propriedade acionária das companhias brasileiras utilizou os seguintes critérios de classificação para as sociedades analisadas: (i) companhias com capital disperso: companhias nas quais os três maiores acionistas seriam titulares de menos do que 25\% do capital social votante; (ii) companhias com controle minoritário: companhias nas quais os três maiores acionistas seriam titulares, em conjunto, de $25 \%$ a $49,9 \%$ do capital social votante, e (iii) companhias com controle majoritário: nas quais os três maiores acionistas são titulares, em conjunto, de mais que $49,9 \%$ do capital social votante.

A dispersão acionária, como se depreende das conclusões obtidas no capítulo anterior, somente se configura em um ambiente acionário com altos níveis de adoção de

\footnotetext{
${ }^{13}$ Silveira, Alexandre de Micelli. A governança corporativa no Brasil e no mundo. Rio de Janeiro: Elsevier: 2010. Destaca-se da análise dos dados levantados pelo autor em 2009 com relação a todas as companhias brasileiras de capital aberto, constatou-se que $90 \%$ das companhias possuíam estrutura de controle majoritário e aproximadamente $9 \% \%$ estrutura de controle minoritário, e $1 \%$ não possuíam acionista controlador.
} 
boas práticas de governança corporativa. A adoção de tais práticas gera maior segurança aos investidores e torna as companhias mais atrativas aos olhos de novos investidores, tal como se propôs quando da criação dos segmentos especiais de governança corporativa, em especial o Novo Mercado.

Considerando-se os deveres e responsabilidades atribuídos pela Lei das S.A. aos acionistas controladores, a adoção de critérios que permitam a distinção entre companhias de capital pulverizado das companhias de capital relativamente pulverizado torna-se importante como forma de garantir a segurança jurídica tão almejada pelos operadores e investidores do mercado de capitais.

O diploma acionário pátrio incorpora, em seu artigo 137, II, b, o conceito jurídico de dispersão acionária, ao conferir a impossibilidade de exercício do direito de retirada pelo acionista dissidente, na hipótese de suas ações possuírem liquidez e estarem dispersas no mercado. Nesse sentido, o referido dispositivo legal, conforme redação dada pela reforma da Lei das S.A. de 2001, define dispersão como hipótese na qual "o acionista controlador, a sociedade controladora ou outras sociedades sob seu controle detiverem menos da metade da espécie ou classe de ação”.

Considerando o escopo do presente estudo, limitado às companhias listadas no Novo Mercado, nas quais o capital social encontra-se dividido exclusivamente por ações ordinárias, a definição apresentada pela Lei das S.A., com base apenas em determinada espécie ou classe de ações, sem considerar a totalidade de ações com direito a voto, não gera consequências práticas para fins da análise aqui proposta. No entanto, a leitura do referido dispositivo demonstra clara conjunção dos conceitos de dispersão acionária e liquidez, de forma que o referido diploma relaciona diretamente a ideia de dispersão acionária à facilidade conferida ao acionista em alienar suas ações no mercado de valores mobiliários.

Dessa forma, tal como apontado por Penteado (2005, p. 19 e ss.), a conceituação apresentada pela Lei das S.A. gera desconforto ao não considerar a possibilidade de existirem companhias nas quais, embora seja conferida boa liquidez às ações de sua emissão, uma parcela relevante de seu capital está concentrada nas mãos de acionista ou bloco de acionistas.

Ora, com base nos mesmos motivos que levam à conclusão pela necessidade de uma subclassificação das companhias com estrutura de propriedade acionária dispersa, o 
conceito geral apresentado pela Lei das S.A. para a caracterização da dispersão acionária deveria ser revisto para que não gere a falsa impressão de ausência de possibilidade de exercício de controle por acionista ou grupo de acionistas que não sejam detentores da maioria do capital social votante. Sem a referida distinção entre companhias de capital disperso, o ordenamento jurídico pátrio, resta por considerar como iguais sociedades que podem ter realidade organizacional completamente diversas.

Dessa forma, a partir do reconhecimento das principais características da propriedade acionária das companhias brasileiras perante um movimento pró-diluição e de busca pela manutenção do controle, a pesquisa objeto desta dissertação será direcionada em busca da identificação da possível existência de um acionista controlador minoritário em companhias de capital disperso listadas no Novo Mercado, tal como se propõe a partir da análise dos resultados obtidos na pesquisa empírica apresentada no capítulo a seguir. 


\section{CAPÍTULO 3 CENÁRIO DAS COMPANHIAS LISTADAS NO NOVO MERCADO}

Conforme demonstrado no capítulo anterior, diversos estudos foram elaborados no âmbito da estrutura da propriedade acionária das companhias brasileiras. Tendo em vista o recente fenômeno de dispersão acionária resultante, entre outros motivos, do considerável aumento do volume de operações realizadas nos últimos anos via mercado de capitais, o presente capítulo apresenta o resultado de pesquisa empírica realizada com o propósito de identificar a atual estrutura de propriedade acionária predominante entre as companhias brasileiras listadas no Novo Mercado, bem como apurar eventuais elementos que contribuam para a verificação da existência do controle minoritário em algumas das companhias listadas no Novo Mercado.

A realização da referida pesquisa foi inspirada, principalmente, em estudo elaborado por Gorga (2008), no qual a autora apurou diversos dados de companhias listadas nos segmentos especiais de governança corporativa da BMF\&BOVESPA, com o objetivo de proporcionar melhor entendimento sobre a migração da estrutura de propriedade do capital concentrada para a estrutura dispersa, conforme citado anteriormente.

Nesse contexto, este estudo foi realizado mediante levantamento de informações divulgadas exclusivamente por companhias listadas no Novo Mercado, em seus respectivos Formulários de Referência e Formulários Cadastrais, nos termos estabelecidos na Instrução CVM nº 480, de 7 de dezembro de 2009 (ICVM 480).

A edição da ICVM 480 teve por objetivo aumentar a fiscalização sobre as companhias abertas, bem como adequar as regras da autarquia à realidade das companhias brasileiras e à demanda de seus investidores, proporcionando, inclusive, maior segurança às operações realizadas no âmbito de companhias com controle gerencial. Também merece destaque a ICVM n⿳ 481 , de 17 de dezembro de 2009, que regulamentou os pedidos públicos de procuração para exercício do direito de voto nas assembleias de companhias abertas. 
Por força da ICVM 480, as principais informações referentes às companhias emissoras de valores mobiliários, tais como descrição de suas atividades, histórico, projeções, fatores de risco, estrutura e composição da administração, estrutura de capital, informações financeiras, operações com partes relacionadas, entre outras, são disponibilizadas ao público em geral de forma objetiva e organizada nos moldes dos padronizados Formulários de Referência e Cadastral, os quais devem ser atualizados regularmente ${ }^{14}$.

Muito embora essas informações já devessem ser publicadas, em grande parte pelas companhias emissoras antes da edição da ICVM 480, a nova estrutura de divulgação imposta pela CVM refez o formulário de informações anuais (IAN), padronizou a qualidade das informações divulgadas a partir de janeiro de 2010, por meio da criação dos Formulários de Referência e Cadastral, e estabeleceu obrigatoriedade de constante atualização desses dados, favorecendo a exatidão das informações disponibilizadas ao mercado em geral, que antes tinha acesso apenas aos detalhes disponibilizados no IAN e antigos prospectos de distribuição.

Sobre a qualidade das informações divulgadas pelas companhias emissoras, vale destacar que o Formulário de Referência entregue à CVM deve conter declaração específica do respectivo diretor presidente e diretor de Relações com Investidores de cada companhia, por meio da qual estes devem atestar que: (i) o documento foi por eles revisado; (ii) as informações apresentadas atendem o disposto na ICVM 480, em especial nos artigos 14 a 19; e (iii) o conjunto de informações apresentadas é retrato verdadeiro,

\footnotetext{
${ }^{14}$ Nos termos do artigo 23 da ICVM 480, o Formulário Cadastral deve ser atualizado sempre que quaisquer de seus dados forem alterados, no prazo de sete dias úteis contados do fato que gerou tal alteração. Sem prejuízo, as informações devem ser atualizadas anualmente no período entre os dias $1^{0}$ e 31 de maio de cada ano. Quanto ao Formulário de Referência, o artigo 24, parágrafo primeiro, da ICVM 480, determina a obrigatoriedade de sua atualização anualmente, no prazo de cinco meses contados da data de encerramento do respectivo exercício social, devendo, ainda, ser parcialmente atualizado no prazo de sete dias úteis contados da ocorrência de determinados eventos, como, alteração na composição da administração; alteração no capital social; alteração dos acionistas controladores ou variações em suas posições iguais ou superiores a cinco por cento de uma mesma espécie ou classe de valores mobiliários; reorganização societária envolvendo a companhia, entre outros.
} 
preciso e completo da situação econômico-financeira da emissora e dos riscos inerentes às suas atividades e seus valores mobiliários de sua emissão ${ }^{15}$.

A ICVM 480 estabelece, ainda, em seu artigo 60, que a divulgação ao mercado (ou entrega à $\mathrm{CVM}$ ) de informações falsas, incompletas, imprecisas ou que induzam o investidor a erro constituirá infração grave, podendo a CVM impor aos infratores as penalidades previstas no parágrafo $3^{\mathrm{o}}$ do artigo 11 , da Lei $\mathrm{n}^{\mathrm{o}} 6.385$, de 7 de dezembro de $1976^{16}$.

É exatamente nesse contexto em que foi desenvolvido o presente capítulo, que apresenta o resultado de pesquisa empírica cuja elaboração se deu mediante aproveitamento da riqueza desse recente banco de dados disponibilizado ao público em geral. Dessa forma, com o propósito de apresentar um panorama da propriedade acionária das companhias brasileiras listadas no Novo Mercado, foram analisadas as principais informações divulgadas por tais companhias em seus Respectivos Formulários de Referência e Cadastral, publicados até 31 de maio de 2013, sendo sempre consideradas as informações constantes do arquivo mais recente (i.e. o último documento divulgado antes da referida data de corte).

Por meio desta pesquisa, pretende-se, ainda, demonstrar o estágio híbrido em que se encontra o mercado brasileiro, o qual, entre outros aspectos, evidencia a existência de cenário contrastante não reconhecido com unanimidade pela doutrina societária, qual seja: a existência de acionista ou grupo de acionistas que, embora detentores de participação minoritária, podem ser considerados detentores do poder de controle, sendo, então,

\footnotetext{
${ }^{15}$ Cf. ICVM 480: "Art. 14. O emissor deve divulgar informações verdadeiras, completas, consistentes e que não induzam o investidor a erro. Art. 15. Todas as informações divulgadas pelo emissor devem ser escritas em linguagem simples, clara, objetiva e concisa. Art. 16. O emissor deve divulgar informações de forma abrangente, equitativa e simultânea para todo o mercado. Art. 17. As informações fornecidas pelo emissor devem ser úteis à avaliação dos valores mobiliários por ele emitidos. Art. 18. Sempre que a informação divulgada pelo emissor for válida por um prazo determinável, tal prazo deve ser indicado. Art. 19. Informações factuais devem ser diferenciadas de interpretações, opiniões, projeções e estimativas. Parágrafo único. Sempre que possível e adequado, informações factuais devem vir acompanhadas da indicação de suas fontes".

${ }^{16}$ Nos termos do artigo 11 , caput e parágrafo $3^{\circ}$, da Lei $\mathrm{n}^{\mathrm{0}}$ 6.385, de 7 de dezembro de 1976, as seguintes penalidades serão aplicadas nos casos de infração grave: "III - suspensão do exercício do cargo de administrador ou de conselheiro fiscal de companhia aberta, de entidade do sistema de distribuição ou de outras entidades que dependam de autorização ou registro na Comissão de Valores Mobiliários; IV - inabilitação temporária, até o máximo de vinte anos, para o exercício dos cargos referidos no inciso anterior; V - suspensão da autorização ou registro para o exercício das atividades de que trata esta Lei; VI - cassação de autorização ou registro, para o exercício das atividades de que trata esta Lei; VII - proibição temporária, até o máximo de vinte anos, de praticar determinadas atividades ou operações, para os integrantes do sistema de distribuição ou de outras entidades que dependam de autorização ou registro na Comissão de Valores Mobiliários; VIII - proibição temporária, até o máximo de dez anos, de atuar, direta ou indiretamente, em uma ou mais modalidades de operação no mercado de valores mobiliários".
} 
relevante a análise das consequências jurídicas dessa constatação, tal como será desenvolvida no Capítulo 4 da presente dissertação.

A pesquisa ora apresentada foi realizada em cinco etapas, conforme detalhadas nos capítulos seguintes, a saber: (i) verificação do perfil das companhias listadas no Novo Mercado; (ii) análise da estrutura de propriedade de capital predominante entre as companhias listadas no Novo Mercado, mediante levantamento das participações societárias de maior relevância; (iii) verificação do perfil dos acionistas das companhias listadas no Novo Mercado que não possuam controle majoritário; (iv) análise das principais disposições dos acordos de acionistas existentes nas companhias nas quais foi identificada a existência de posição minoritária relevante, conforme item "iii" acima; e (v) verificação da adoção de cláusulas de proteção à dispersão acionária pelas mesmas companhias objeto da análise realizada na etapa "iv" acima.

Sobre a análise dos dados apresentados nos capítulos a seguir, cumpre destacar que, para o propósito da presente pesquisa, foram consideradas todas as companhias que se encontravam listadas no segmento do Novo Mercado em 31 de maio de 2013, data que coincide com a data de corte estabelecida para o acesso às informações objeto de levantamento. Dessa forma, não foi considerado, para fins deste trabalho, o eventual ingresso de novas companhias ao grupo listado no Novo Mercado, após a referida data de corte, bem como a possível saída de determinadas companhias em decorrência de operações de reorganização societária, fechamento de capital e/ou simples migração de segmento de governança, após tal data ${ }^{17}$.

Importante destacar, por fim, que os dados ora apresentados não consideram eventuais omissões ou erros na declaração de informações pelas companhias objeto de análise, conforme critérios exigidos pela legislação aplicável. Dessa forma, a veracidade, integridade e completude das informações divulgadas pelas companhias listadas no Novo Mercado à CVM constituiu relevante premissa para a elaboração da pesquisa objeto deste capítulo.

\footnotetext{
${ }^{17}$ Em 31 de maio de 2013, foram identificadas 129 companhias listadas no Novo Mercado, conforme informações apresentadas no Capítulo 3.1 a seguir. Já ao final de 2013, o grupo de companhias listadas no Novo Mercado passou a ser representado por 134 companhias, segundo dados divulgados no Boletim Diário de Informações da BM\&FBOVESPA, n. 248, 30 dez. 2013. Disponível em $<$ http://www.bmfbovespa.com.br/download/BOLETINSDIARIOS/boletimdiario_20131230.pdf $>$. Acesso em 8 jan. 2014.
} 


\subsection{Perfil das Companhias}

Na primeira etapa desta pesquisa, buscou-se identificar as principais características das 129 companhias listadas no Novo Mercado ${ }^{18}$, conforme informações divulgadas nos respectivos Formulários Cadastrais e dados constantes nos estatísticas divulgadas pela BM\&FBOVESPA, de modo a proporcionar um panorama do perfil das companhias integrantes do Novo Mercado.

Para tanto, de acordo com os dados da Tabela 1 (Apêndice A), foram analisadas as seguintes informações das companhias: (i) denominação social; (ii) setor de atividade; (iii) data de constituição; (iv) data de registro na CVM; (v) data de listagem no segmento especial do Novo Mercado; (vi) identificação se a companhia integra ou não o Índice Bovespa (Ibovespa) e/ou o Índice Brasil (IBRX); e (vii) valor do patrimônio líquido consolidado em 31 de dezembro de 2012, sendo considerado, ainda, o valor de mercado de algumas das companhias, apurado em data mais recente, 31 de dezembro de 2013.

Com base nas informações disponibilizadas pelas companhias, em seus respectivos Formulários Cadastrais, foram identificados os setores de atividade que possuem maior ou menor representatividade no Novo Mercado ${ }^{19}$, a saber: (i) construção civil, materiais de construção e decoração (27); (ii) comércio - atacado e varejo (14); (iii) serviços de transporte e logística (10); (iv) alimentos (8); (v) agricultura (açúcar, álcool e cana) (7); (vi) máquinas, equipamentos, veículos e peças (7); (vii) empresa administradora de participações - sem atividade principal (6); (viii) energia elétrica (6); (ix) comunicação e informática (5); (x) têxtil e vestuário (5); (xi) petróleo e gás (4); (xii) serviços médicos (4); (xiii) educação (3); (xiv) extração mineral (3); (xv) intermediação financeira (3); (xvi) farmacêutico e higiene (2); (xvii) petroquímicos e borracha (2); (xviii) saneamento, serviços de água e gás (2); (xix) seguradoras e corretoras (2); (xx) bancos (1); (xxi) bolsas

18 Para fins de determinação das companhias listadas no segmento especial do Novo Mercado da BM\&FBOVESPA, foram consideradas as companhias cujo registro no segmento tenha sido realizado até 31 de maio de 2013 (data de corte), conforme dados do Boletim Diário de Informações da BM\&FBOVESPA, n. 102, 31 maio 2013. Disponível em: <http://www.acervobmfbovespa.com.br/Archive/38914\#>. Acesso em: 26 jul. 2013. Relação atualizada de companhias listadas no Novo Mercado disponível em: $<$ http://www.bmfbovespa.com.br/Cias-Listadas/Empresas-Listadas/BuscaEmpresaListada.aspx?idioma=ptbr>. Acesso em: 20 ago. 2013.

${ }^{19}$ Setores de atividade apresentados de acordo com a classificação disponibilizada eletronicamente pela CVM, quando do preenchimento do Formulário Cadastral pela companhia emissora. Informações disponíveis no capítulo Dados Cadastrais de cada Formulário Cadastral divulgado até 31 de maio de 2013. Disponível em: <http://www.cvm.gov.br>. Acesso em: ago. 2013. 
de valores, mercadorias e futuros (1); (xxii) brinquedos e lazer (1); (xxiii) empresa administradora de participações - seguradoras e corretoras (1); (xxiv) gráficas e editoras (1); (xxv) hospedagem e turismo (1); (xvi) metalurgia e siderurgia (1); (xvii) papel e celulose (1); e (xxviii) telecomunicações (1).

Dentre os setores acima, é nítida a predominância de atividades relacionadas à construção civil, materiais de construção e decoração; ao comércio (atacado e varejo), e a serviços de transporte e logística, enquanto outras ainda possuem pouca representatividade no Novo Mercado. No entanto, vale destacar que, embora determinados setores possuam pouca ou nenhuma representatividade no Novo Mercado, estes podem existir em alta concentração em outros segmentos especiais de governança, como, por exemplo, aqueles relacionados a atividades de instituições financeiras e companhias siderúrgicas, que se encontram expressamente representadas no mercado de capitais por companhias listadas no segmento especial do Nível $1^{20}$.

No que se refere ao cronograma apurado entre as datas de constituição das companhias objeto de estudo e as datas de seus respectivos registros perante a CVM e adesão aos termos do Regulamento do Novo Mercado, não foi possível determinar um padrão de prazos, restando clara a diversidade entre as companhias que integram o grupo. Além de existirem companhias com diferentes tipos de atuação, conforme descrito acima, foi identificada tanto a existência de companhias com longo prazo de duração (constituídas antes dos anos 2000 - véspera do advento do Novo Mercado), como companhias com menor prazo de existência, cuja constituição se deu em ou após os anos 2000.

Das 129 companhias analisadas, 53 (41,09\%) foram constituídas em ou após os anos 2000, tendo, portanto, no máximo, pouco mais do que uma década de existência. As 76 companhias remanescentes $(58,91 \%)$ foram constituídas antes dos anos 2000 .

\footnotetext{
${ }^{20}$ Mediante levantamento das companhias listadas na BM\&FBOVESPA e classificadas dentro do segmento de bancos, foram apuradas 27 companhias, das quais 14 encontram-se listadas em segmentos especiais de governança corporativa, sendo (i) sete companhias listadas no Nível 1 (Banco Bradesco S.A.; Banco Estado do Rio Grande do Sul S.A.; Banco Industrial e Comercial S.A.; Banco Panamericano S.A.; Itaú Unibanco Holding S.A.; Itausa Investimentos Itaú S.A., e Paraná Banco S.A.); (ii) seis companhias listadas no Nível 2 (Banco ABC Brasil S.A.; Banco Daycoval S.A.; Banco Indusval S.A.; Banco Pine S.A.; Banco Santander Brasil S.A., e Banco Sofisa S.A.); e (iii) apenas uma companhia listada no Novo Mercado (Banco do Brasil S.A.). Disponível em: <http://www.bmfbovespa.com.br/Cias-Listadas/Empresas-Listadas/BuscaEmpresa Listada.aspx?segmento=Bancos\&idioma=pt-br $>$. Acesso em: 6 jan. 2014. Adicionalmente, dentre as cinco companhias metalúrgicas com ações negociadas na BM\&FBOVESPA, quatro delas encontram-se listadas em segmento especial de governança corporativa, sendo todas listadas no Nível 1, a saber: Companhia Ferro Ligas da Bahia (Ferbasa); Gerdau S.A.; Metalúrgica Gerdau S.A.; Usinas Siderúrgicas de Minas Gerais (Usiminas). Disponível em: <http://www.bmfbovespa.com.br/cias-listadas/empresaslistadas/BuscaEmpresaListada.aspx?segmento=Siderurgia\&idioma=pt-br>. Acesso em: 6 jan. 2014.
} 
$\mathrm{Na}$ comparação dos períodos compreendidos entre as datas de registro das companhias na CVM e respectivo alistamento no Novo Mercado, é possível identificar que 81 companhias $(62,79 \%)$ aderiram aos termos do Regulamento do Novo Mercado em prazo igual ou inferior a seis meses contados da data de obtenção de seus respectivos registros como companhias abertas perante a CVM, o que evidencia a forte tendência de adesão direta ao Novo Mercado em detrimento da possibilidade de migração gradual dos sistemas menos exigentes (Níveis 1 e 2 de governança) rumo ao Novo Mercado ${ }^{21}$.

Ainda no âmbito da análise do perfil das companhias listadas no Novo Mercado, foram identificadas no grupo as companhias que compõem o Ibovespa e o IBRX. Tal identificação se fez proposta devido à influência de tais índices (principalmente o Ibovespa) na análise do comportamento do mercado acionário e ao objetivo de proporcionar maiores subsídios para análise do porte das companhias que integram o Novo Mercado.

Nos termos da Metodologia do Ibovespa, divulgada pela BM\&FBOVESPA (2013), o referido índice representa

\begin{abstract}
o resultado de uma carteira teórica de ativos, elaborada de acordo com os critérios estabelecidos em sua metodologia. [...] O objetivo do Ibovespa é ser o indicador do desempenho médio das cotações dos ativos de maior negociabilidade e representatividade do mercado de ações brasileiro. Serão selecionados para compor o Índice Bovespa, os ativos que atendam cumulativamente os critérios abaixo: [...] 2. Ter presença em pregão de $95 \%$ (noventa e cinco por cento) no período de vigência das 3 (três) carteiras anteriores. 3. Ter participação em termos de volume financeiro maior ou igual a $0,1 \%$ (zero vírgula um por cento) no período de vigência das 3 (três) carteiras anteriores. [...]. ${ }^{22}$
\end{abstract}

Já o índice IBRX representa o retorno de carteira teórica de ativos composta por cem ações selecionadas entre as mais negociadas na Bovespa, em termos de número de negócios e volume financeiro, sendo tal liquidez considerada no período dos doze meses anteriores à seleção das ações, que serão ponderadas na carteira do índice pela respectiva

${ }^{21}$ Em linha com a tendência verificada em outras economias, a BM\&FBOVESPA criou o Níveis 1 e 2 de Governança Corporativa com o intuito de angariar companhias que tivessem interesse em adotar regras de disclosure, sem impor a tais companhias regras tão exigentes quanto as aplicáveis às companhias listadas no Novo Mercado. A intenção clara seria atrair as companhias para uma experiência inicial em segmento de governança menos rigoroso, possibilitando a posterior adesão a níveis de governança corporativa mais criteriosos. No entanto, o que se verifica, na prática, é que tais segmentos concentram número expressivo de companhias atuantes em determinados setores, como é o caso das instituições financeiras e sociedades de economia mista que se encontram altamente concentradas no Nível 1, conforme exposto anteriormente.

${ }^{22}$ BM\&FBOVESPA, Metodologia do Índice Bovespa (Ibovespa), datada de outubro de 2013. Disponível em: $<$ http://www.bmfbovespa.com.br/Indices/download/Nova-Metodologia-do-Indice-Bovespa-R.pdf>. Acesso em: 12 jan. 2014. 
quantidade disponível à negociação no mercado. As ações selecionadas deverão, ainda, atender ao critério de terem sido negociadas em, pelo menos, $70 \%$ dos pregões ocorridos nos doze meses anteriores à formação da carteira ${ }^{23}$.

Diante das diferentes metodologias adotadas para a composição dos índices acima, a pesquisa realizada considerou a participação de companhias do Novo Mercado tanto no índice Ibovespa quanto no IBRX ${ }^{24}$. Para tanto, foram consideradas as composições das carteiras teóricas de cada índice para o primeiro quadrimestre de $2014^{25}$.

Com base no levantamento realizado, identificou-se que, dentre as 72 companhias representativas da carteira Ibovespa, 42 encontram-se listadas no Novo Mercado, representando, portanto, um peso aproximado de 58,33\% da carteira total, enquanto tais companhias representam apenas $32,56 \%$ do total das companhias listadas no Novo Mercado objeto de análise (129).

A mesma análise realizada para as companhias que compõem a carteira IBRX divulgada para o primeiro quadrimestre de 2014 também evidenciou a grande diversidade entre as companhias listadas no Novo Mercado, tal como indicada anteriormente. Dentre as 100 companhias que compõem a carteira IBRX, 62 encontram-se listadas no Novo Mercado, representando, portanto, um peso de $62 \%$ da carteira, enquanto essas companhias representam, aproximadamente, 48,06\% do total listado no Novo Mercado objeto de análise.

\footnotetext{
${ }^{23}$ Definição e metodologia de composição da carteira IBRX apresentada conforme esclarecimentos divulgados pela BM\&FBOVESPA na rede mundial de computadores. Disponível em: <http://www.bmfbovespa.com.br/indices/ ResumoIndice.aspx?Indice=Ibovespa\&Idioma=pt-br>. Acesso em: 15 jan. 2014. Em janeiro de 2003, a BM\&FBOVESPA passou a divulgar o Índice Brasil 50 (IBrX-50), que adota os mesmos critérios do IBRX para composição de sua, mas leva em conta apenas as cinquenta ações mais negociadas.

${ }^{24}$ Conforme bem analisado por André Rocha, no caderno O Estrategista da publicação Valor Investe, veiculada pelo jornal Valor Econômico, em 26 de setembro de 2011, o Ibovespa é criticado, principalmente, por basear-se primordialmente na liquidez das ações que integram sua carteira. Desse modo, se a negociação de determinado título crescer, independentemente do contexto, o peso de tais ações no índice segue a mesma linha de crescimento. Ou seja, ainda que, por exemplo, as ações estejam perdendo importância junto aos investidores, a relevância desses títulos no Ibovespa aumentará. Análise de André Rocha na íntegra disponível em: <http://www.valor.com.br/valor-investe/o-estrategista/1019138/ ibovespa-ou-ibrx>. Acesso em: 10 jan. 2014. Nesse contexto, vale citar, por exemplo, a repercussão das negociações das ações emitidas pelas companhias do Grupo X, quando da queda do império construído por Eike Batista, semanas antes do pedido de recuperação judicial apresentado pela petrolífera OGX, em 30 de outubro de 2013. No auge das reclamações e veiculação de notícias com denúncias sobre o mau desempenho das companhias do grupo, a OGX representava uma das cinco companhias de maior peso na carteira do Ibovespa divulgada para o último quadrimestre de 2013 (4,259\%). Dados disponíveis em: <http://www.bmfbovespa.com.br/pt-br/ noticias/2013/BMFBOVESPA-divulga-carteira-do-Ibovespa-a-vigorar-no-proximo-quadrimestre-de-20132013-09-02.aspx?tipoNoticia= 1\&idioma=pt-br>. Acesso em: 10 jan. 2014.

${ }^{25}$ Composição da carteira do Ibovespa disponível em: <http://www.bmfbovespa.com.br/indices/Resumo CarteiraQuadrimestre.aspx? Indice=Ibovespa\&idioma=pt-br $>$. Acesso em: 6 jan. 2014. Composição da carteira do IBRX disponível em: <http://www.bmfbovespa.com.br/indices/ResumoCarteiraTeorica.aspx?

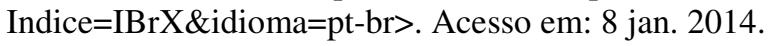


Seguindo o propósito de apresentar elementos para uma visão geral do perfil das companhias integrantes do Novo Mercado, apurou-se, por fim, o valor do patrimônio líquido $^{26}$ de cada uma das companhias integrantes do Novo Mercado, em 31 de dezembro de 2012, conforme dados dos respectivos Formulários Cadastrais divulgados até 31 de maio de 2013.

Mediante tal levantamento, identificou-se que, dentre as 129 companhias analisadas: (i) 53 possuem valor de patrimônio líquido inferior a $\mathrm{R} \$ 1$ bilhão (aproximadamente 41,08\%); (ii) 69 possuem valor de patrimônio líquido igual ou superior a R\$ 1 bilhão, mas não superior a R\$ 10 bilhões (aproximadamente 53,49\%); (iii) 6 possuem valor de patrimônio líquido igual ou superior a $\mathrm{R} \$ 11$ bilhões, mas não superior a R\$ 50 bilhões (aproximadamente 4,65\%); e (iv) apenas 1 companhia possui valor de patrimônio líquido superior a $\mathrm{R} \$ 50$ bilhões (aproximadamente 0,77\%): Banco do Brasil S.A., com valor total de $\mathrm{R} \$ 69.898 .000 .000,00$.

Na mesma linha, foi levantado o valor de mercado de algumas das companhias listadas no Novo Mercado, conforme avaliação divulgada pela BM\&FBOVESPA, com base nas ações negociadas na bolsa de valores em dezembro de $2013^{27}$, mediante apuração do resultado da multiplicação da quantidade de ações emitidas por cada companhia, pela sua respectiva cotação de mercado.

Como a apuração do valor de mercado de uma companhia é realizada com base na cotação de suas ações na bolsa de valores, pode-se dizer que o valor apurado considera não apenas a atual situação financeira de uma companhia, como também as expectativas do

\footnotetext{
${ }^{26}$ Conforme definido nos itens 4.4 e 4.20 e seguintes do Pronunciamento Conceitual Básico (R1) do Comitê de Pronunciamentos Contábeis (CPC) aprovado em 2 de dezembro de 2011, e que estabeleceu a Estrutura Conceitual para Elaboração e Divulgação de Relatório Contábil-Financeiro: “4.4. Os elementos diretamente relacionados com a mensuração da posição patrimonial e financeira são os ativos, os passivos e o patrimônio líquido. (...) patrimônio líquido é o interesse residual nos ativos da entidade depois de deduzidos todos os seus passivos. (...) 4.20. Embora o patrimônio líquido seja definido no item 4.4 como algo residual, ele pode ter subclassificações no balanço patrimonial. Por exemplo, na sociedade por ações, recursos aportados pelos sócios, reservas resultantes de retenções de lucros e reservas representando ajustes para manutenção do capital podem ser demonstrados separadamente. Tais classificações podem ser relevantes para a tomada de decisão dos usuários das demonstrações contábeis quando indicarem restrições legais ou de outra natureza sobre a capacidade que a entidade tem de distribuir ou aplicar de outra forma os seus recursos patrimoniais. Podem também refletir o fato de que determinadas partes com direitos de propriedade sobre a entidade têm direitos diferentes com relação ao recebimento de dividendos ou ao reembolso de capital." Disponível em: <http://www.cpc.org.br/pdf/CPC00_R1.pdf >. Acesso em: 10 jan. 2014.

${ }^{27}$ Valores divulgados pela BM\&FBOVESPA apenas com relação a determinadas companhias, não havendo, portanto, informações de todas as companhias listadas no Novo Mercado. Dados utilizados disponíveis em: <http://www.bmfbovespa.com.br/capitalizacao-bursatil/ResumoBursatilMensal.aspx?idioma=pt-br>. Acesso em: 10 jan. 2014. Esclarecimentos sobre apuração do valor de mercado disponíveis em: $<$ http://www.bmfbovespa.com.br/indices/ResumoCapitalizacaoBursatil.aspx? Indice=IBOVESPA\&idioma=p t-br>. Acesso em: 11 jan. 2013.
} 
mercado para futuro de suas atividades, enquanto a avaliação, com base no patrimônio líquido, retrata apenas uma foto da posição financeira da companhia divulgada trimestralmente em suas demonstrações financeiras. Por essa razão, julgou-se interessante apresentar, neste trabalho, o resultado da avaliação a mercado de tais companhias, ainda que o longo período de intervalo entre as datas de apuração dos valores de mercado e de patrimônio líquido identificados (dezembro/2013 e dezembro/2012, respectivamente) não tenha favorecido a análise comparativa de tais valores ${ }^{28}$.

Conforme avaliação divulgada pela BM\&FBOVESPA, em relação ao mês de dezembro de 2013, das 56 companhias listadas no Novo Mercado e objeto da referida avaliação, (i) 4 possuem valor de mercado inferior a $\mathrm{R} \$ 1$ bilhão (aproximadamente 7,14\%); (ii) 37 possuem valor de mercado igual ou superior a $\mathrm{R} \$ 1$ bilhão, mas não superior a R\$ 10 bilhões (aproximadamente 66,07\%); (iii) 13 possuem valor de mercado igual ou superior a R\$ 11 bilhões, mas não superior a R $\$ 50$ bilhões (aproximadamente 23,21\%); e (iv) 2 possuem valor de mercado superior a $\mathrm{R} \$ 50$ bilhões (aproximadamente, 3,57\%): Banco do Brasil S.A., com valor total de R\$ 69.916.175.290,00, e Cielo S.A., com valor total de $\mathrm{R} \$ 51.608 .480 .540,00$.

A análise dos valores indicados acima corrobora a conclusão apresentada anteriormente, evidenciando, mais uma vez, a grande diversidade existente entre as companhias listadas no Novo Mercado, que é composto por empresas de diferentes portes e períodos de existência.

É exatamente nesse contexto em que se destaca a importância do estudo objeto da presente dissertação. Justamente por se tratar de um grupo diversificado de companhias, não se pode preestabelecer um padrão para a estrutura da propriedade acionária de tais

\footnotetext{
${ }^{28}$ São comuns análises entre o valor de mercado e o valor do patrimônio líquido das companhias realizadas com o objetivo de identificar o nível de confiança do mercado em tais empresas, posto que, em alguns casos, é possível encontrar companhias cujo valor de mercado é inferior ao valor de seu patrimônio líquido, ou seja, mercado em geral, com base nas expectativas de resultados futuros para esta companhia, resta por avaliá-la por valor inferior ao que poderia ser apurado em sua eventual liquidação. Em recente análise, divulgada pela Revista Exame, em 3 de janeiro de 2014, às 15h54min, foram identificadas 20 companhias integrantes do Ibovespa (à época do levantamento) cujo valor de mercado foi apurado em montante inferior ao respectivo patrimônio líquido ao final de 2013. Dentre tais companhias, dez encontram-se listadas no Novo Mercado: Brookfield Incorporações S.A.; Rossi Residencial S.A.; MMX Mineração e Metálicos S.A.; PDG Realty S.A. Empreendimentos e Participações; Marfrig Alimentos S.A.; Gafisa S.A.; BR Properties S.A.; BR Malls Participações S.A.; MRV Engenharia e Participações S.A.; Vanguarda Agro S.A. Disponível em: $<$ http://exame.abril.com.br/mercados/noticias/as-20-empresas-que-custam-menos-do-que-valem-nabovespa\#15>. Acesso em: 11 jan. 2014. Análise semelhante também foi apresentada no artigo As 20 Ações mais "Baratas" da Bovespa em Relação ao Patrimônio Líquido. GASPARANI, Carolina. Revista InfoMoney, 30 set. 2013, 14h42min. Disponível em: <http://www.infomoney.com.br/mercados/acoes-eindices/noticia/2983607/acoes-mais-baratas-bovespa-relacao-patrimonio-liquido>. Acesso em: 11 jan. 2014.
} 
companhias, pressupondo simplesmente a predominância de uma estrutura de capital concentrado, sem o devido reconhecimento das nuances existentes entre as companhias do grupo. Mister se faz, portanto, a análise da estrutura da propriedade acionária de tais companhias, com o objetivo de identificar os reflexos do movimento de dispersão acionária, ocorrido nos últimos anos, e apurar a eventual existência de controle societário detido por acionista ou grupo de acionistas minoritários, conforme se fará nos capítulos seguintes.

Para mais detalhes sobre os dados e resultados apresentados neste Capítulo 3.1, vide Tabela 1 (Apêndice A).

\subsection{Estrutura de Capital}

Conforme já destacado, o desenvolvimento do mercado de capitais brasileiro na última década favoreceu a dispersão da base acionária das companhias abertas, em contraste à histórica concentração de poder e gestão familiar até então predominantes no País. A reflexão proposta neste Capítulo 3.2 tem por objetivo analisar os efeitos da transição do mercado de capitais brasileiro para um mercado mais complexo e disperso, de modo a identificar empiricamente a estrutura de propriedade do capital atualmente predominante entre as companhias listadas no Novo Mercado, e encontrar elementos que permitam a identificação de companhias controladas por acionista ou grupo de acionistas que não sejam detentores da maioria do capital social.

Para tanto, a segunda etapa da pesquisa empírica apresentada neste Capítulo 3 foi realizada com base na participação societária detida pelos cinco maiores acionistas de cada companhia listada no Novo Mercado, mediante levantamento dos dados constantes dos itens 15.1 e 15.2 dos Formulários de Referência divulgados pelas companhias até 31 de maio de 2013. Nos termos da ICVM 480, a companhia emissora deve prestar, nos referidos itens, informações atualizadas sobre a participação detida por acionista ou grupo de acionistas controladores, bem como por acionistas detentores de participação igual ou superior a 5\% de uma mesma classe ou espécie de ações de emissão da companhia, 
devendo ser indicado, ainda, entre outras informações detalhadas sobre tais acionistas, se este figura como acionista controlador e/ou é signatário de acordo de acionistas ${ }^{29}$.

Mediante o levantamento de tais dados, conforme apresentados na Tabela 2 (Apêndice B), foi possível identificar o percentual total de participação detido pelos cinco maiores acionistas de cada companhia, bem como avaliar a participação societária total detida pelos acionistas que foram indicados pelas emissoras como detentores do poder de controle (acionistas controladores), sendo esta última a principal análise empírica apresentada no âmbito do escopo da presente dissertação, uma vez que, partindo-se da exclusão das companhias com acionistas controladores majoritários (sejam eles acionistas detentores de participação isolada superior a 50\% do capital social total, ou grupo de acionistas cuja participação societária conjunta corresponda a percentual superior a $50 \%$ do capital total), buscou-se identificar dentre as companhias remanescentes a existência de acionistas titulares do controle societário, ainda que detentores de participação não majoritária.

Das participações societárias detidas nas 129 companhias objeto de análise, identificou-se que o percentual de participação do primeiro maior acionista varia entre $78,87 \%$ do capital social total (quantidade esta que, no caso, confronta o percentual

\footnotetext{
${ }^{29}$ Nos termos do Anexo 24 à ICVM 480 (Conteúdo do Formulário de Referência), os itens 15.1 e 15.2 devem ser preenchidos com as seguintes informações: "15.1: Identificar o acionista ou grupo de acionistas controladores, indicando em relação a cada um deles: a. nome; b. nacionalidade; c. CPF/CNPJ; d. quantidade de ações detidas, por classe e espécie; e. percentual detido em relação à respectiva classe ou espécie; f. percentual detido em relação ao total do capital social; g. se participa de acordo de acionistas; h. se o acionista for pessoa jurídica, lista contendo as informações referidas nos subitens "a" a "d" acerca de seus controladores diretos e indiretos, até os controladores que sejam pessoas naturais, ainda que tais informações sejam tratadas como sigilosas por força de negócio jurídico ou pela legislação do país em que forem constituídos ou domiciliados o sócio ou controlador; i. data da última alteração. 15.2: Em forma de tabela, lista contendo as informações abaixo sobre os acionistas, ou grupos de acionistas que agem em conjunto ou que representam o mesmo interesse, com participação igual ou superior a 5\% de uma mesma classe ou espécie de ações e que não estejam listados no item 15.1: a. nome; b. nacionalidade; c. CPF/CNPJ; d. quantidade de ações detidas, por classe e espécie; e. percentual detido em relação à respectiva classe ou espécie e em relação ao total do capital social; f. se participa de acordo de acionistas; g. data da última alteração." Por meio do Ofício-Circular/CVM/SEP 1, de 28 de fevereiro de 2013 (Ofício-Circular CVM/SEP 1/2013), a CVM divulga às companhias abertas orientação geral sobre o preenchimento do Formulário de Referência. Ao tratar sobre o preenchimento dos itens 15.1 e 15.2 do formulário, esclarece a autarquia: "Neste item [15.1], o emissor deve prestar informações atualizadas sobre a identificação e a participação detida pelo acionista ou grupo de acionistas controladores do emissor, até a pessoa natural, em linha com as informações exigidas nas letras "a" a "i". Todas as participações detidas, direta ou indiretamente, por acionista ou grupo de acionistas controladores no capital social do emissor deverão ser informadas. (...) Neste item [15.2], o emissor deve prestar informações sobre a identificação dos acionistas, ou grupos de acionistas que agem em conjunto ou que representam o mesmo interesse, cuja participação total, direta ou indireta, seja igual ou superior a $5 \%$ de uma mesma classe ou espécie de ações, que não estejam listados no item 15.1, em linha com as informações exigidas nas letras 'a' a 'g'”. Disponível em <http://www.cvm.gov. br/port/atos/oficios/Of\%C3\%ADcio\%20Circular\%20SEP\%20n\%C2\%BA\%2001-2013\%20-\%200rienta\% C3\%A7\%C3\%B5es\%20Gerais.pdf>. Acesso em: 11 jan. 2013.
} 
mínimo de ações em circulação preestabelecido pelo Regulamento do Novo Mercado, i.e. $25 \%$ do capital social total) e $4,99 \%$ do capital social total, o que resulta em uma participação média de $34,16 \%$ do capital social total detida pelo maior acionista.

Sob a perspectiva de uma estrutura de capital concentrada, foram identificadas apenas 37 companhias $(28,68 \%$ do total) nas quais a figura de um único acionista detentor de participação superior a $50 \%$ do capital social total é existente; ou seja, a figura do acionista controlador majoritário individual não é predominante entre as companhias listadas no Novo Mercado. Para essas companhias, a participação do maior acionista controlador varia entre $78,87 \%$ do capital social total e $50,14 \%$, representando uma participação média no capital de 59,23\%.

Dentre as 92 companhias restantes (71,32\% do total analisado), ou seja, aquelas que não possuem a figura de um único acionista detentor do controle majoritário, apenas 37 $(28,68 \%$ do total analisado e 40,22\% do total de companhias sem único acionista controlador majoritário) declararam em seus respectivos formulários que o seu maior acionista não figurava como acionista controlador, enquanto as demais 55 (42,64\% do total analisado e 57,78\% do total de companhias sem único acionista controlador majoritário) classificaram seus maiores acionistas como controladores, ainda que detentores de participação inferior à maioria do capital social. Tal constatação evidencia (i) a baixa predominância entre as companhias listadas no Novo Mercado do controle majoritário isolado nas mãos de único acionista e (ii) a possibilidade de existência de outros arranjos de controle societário interno, como o controle compartilhado.

Muito embora a baixa quantidade de companhias com um único acionista detentor isoladamente da maioria do capital social evidencie claramente um movimento de dispersão da base acionária das companhias listadas no Novo Mercado, as participações societárias detidas pelos demais acionistas nas companhias sem esse controle majoritário isolado devem ser objeto de análise, a fim de se apurar a existência de controle societário interno detido por acionista ou grupo de acionistas de tais companhias.

Ou seja, antes de defender a baixa representatividade do controle majoritário entre as companhias listadas no Novo Mercado, as participações detidas pelos principais acionistas de tais companhias devem ser consideradas em conjunto, para verificar eventual compartilhamento do controle entre tais acionistas. 
Conforme destacado por Comparato (2005, p. 63):

[...] o bloco majoritário pode não ser constituído por um único acionista, nem se apresentar, necessariamente, como um grupo monolítico de interesses. É mesmo usual que dois ou mais acionistas, ou grupos de acionistas, componham a maioria, associando interesses temporária ou permanentemente convergentes. Pode-se falar, em tais hipóteses, de um controle conjunto ou por associação.

Com o intuito de identificar eventual compartilhamento do controle societário e aprimorar os elementos favoráveis à identificação da estrutura de capital predominante entre as companhias listadas no Novo Mercado e à identificação do controle societário detido por acionistas não majoritários, foi considerada, em uma segunda análise, a somatória das participações detidas pelos cinco maiores acionistas de cada companhia, sendo ainda destacada a soma de participação detida exclusivamente por acionistas identificados como controladores ${ }^{30}$, conforme indicado nas colunas Total de Ações e Total Controle da Tabela 2 (Apêndice B).

Por meio da análise das participações detidas em conjunto pelos maiores acionistas das companhias listadas no Novo Mercado, identificou-se que os percentuais totais de participação desse grupo de acionistas variam de, aproximadamente, 4,99\% a 99,91\% do capital social total, representando uma participação média de, aproximadamente, 56,33\% do capital social total; se considerada a participação dos três maiores acionistas, esse percentual sofre pequena redução para, aproximadamente, $51,44 \%^{31}$.

As médias de participação apuradas acima, por encontrarem-se restritas a pequeno número de acionistas, evidenciam que, embora tenha ocorrido expressivo movimento de dispersão acionária entre as companhias brasileiras, ainda existe uma relevante concentração na propriedade do capital social das companhias brasileiras de capital aberto, cenário bastante diferente do grau de dispersão acionária identificado em companhias dos

\footnotetext{
${ }^{30}$ Vale destacar que a CVM, nas orientações gerais divulgadas sobre o preenchimento do Formulário de Referência (ICVM 480 e Ofício-Circular CVM/SEP 1/2013) não apresenta critérios objetivos a serem observados pelas companhias emissoras quando da classificação do acionista como controlador para fins de preenchimento dos itens 15.1 e 15.2 do formulário. Dessa forma, para fins do presente trabalho, foi considerado que as companhias se utilizaram dos próprios preceitos estabelecidos na Lei das S.A. para a caracterização do acionista controlador.

${ }^{31}$ Importante lembrar que, para esta pesquisa, foram consideradas apenas as participações indicadas pelas companhias nos itens 15.1 e 15.2 dos respectivos Formulários de Referência. Por essa razão, acionistas, por exemplo, com participação inferior a $5 \%$ do capital social e que não exercem posição de controlador não foram computados nos cálculos de maiores acionistas das companhias objeto de análise. Destaca-se, ainda, que, conforme dados apresentado na Tabela 2 (Apêndices), algumas companhias possuem menos do que cinco acionistas indicados nos referidos itens de seus respectivos formulários.
} 
Estados Unidos e do Reino Unido, por exemplo, cujas ações encontram-se, em sua maioria, claramente dispersas no mercado.

Conforme citado anteriormente, Berle e Means (1968, p. 47), mediante análise de dados levantados em 1929, constataram que diversas companhias norte-americanas possuíam alto grau de dispersão acionária, entre elas as maiores companhias de capital aberto dos Estados Unidos: Pennsylvania Railroad (setor ferroviário); United States Steel Corporation (setor metalúrgico), e American Telephone and Telegraph Company (setor de infraestrutura), nas quais não existia sequer um acionista detentor de participação superior a $1 \%$ do capital social. As maiores participações identificadas em tais companhias eram de $0,34 \%, 0,70 \%$ e $0,90 \%$, respectivamente.

Na mesma linha, vale citar apuração mais recente elaborada por Becht (2003), na qual, mediante verificação da distribuição do capital social de companhias abertas em diversas partes do mundo, constatou-se que, nos Estados Unidos, apenas 7,6\% das companhias listadas na NYSE possuíam um bloco de controle detentor de participação correspondente a, pelo menos, $25 \%$ do capital social, e apenas 1,7\% das companhias listadas na NYSE possuíam bloco de controle detentor de participação majoritária. A mesma análise foi feita para companhias listadas na National Association of Securities Dealers Automated (NASDAQ), tendo sido apurado, respectivamente, os percentuais de $5,2 \%$ e $2 \%$ das companhias listadas. Já no âmbito das companhias listadas no Reino Unido, identificou-se que apenas $15,9 \%$ possuíam um bloco de controle detentor de participação correspondente a, pelo menos, $25 \%$ do capital social, enquanto apenas 2,4\% das companhias listadas detinham um bloco de controle majoritário.

Considerando-se que, conforme já apontado, a média das participações detidas pelos maiores acionistas das companhias listadas no Novo Mercado é de 34,16\% do capital social total, a participação conjunta detida pelos maiores acionistas demonstra que dois ou mais acionistas das companhias analisadas podem, em conjunto, coordenar seus direitos de voto e exercer controle sobre as atividades sociais, ainda que o maior acionista não esteja apto a exercê-lo isoladamente.

Semelhante conclusão foi apontada em estudo já citado de Gorga (2008, p. 28). Ao analisar 65 companhias listadas no Novo Mercado e nas quais a presença de um único acionista controlador era ausente, identificou-se que o maior acionista possuía participação média de 26,23\% do capital social, enquanto os três maiores detinham, em conjunto, $47,28 \%$, e os cinco maiores, $54.73 \%$. Quanto às demais companhias listadas no segmento e 
nas quais foi identificada a figura de um único acionista detentor da maioria do capital social, apurou-se que o maior acionista detinha participação média de $60,87 \%$ das ações.

Cita-se, ainda, interessante resultado obtido em pesquisa elaborada por Oioli (2011). A partir da análise da estrutura acionária de 92 companhias listadas no Novo Mercado, na data-base de 31 de dezembro de 2007, o autor identificou que 17,39\% das companhias declararam não possuir acionista controlador, sendo que "aproximadamente 49\% das companhias eram de capital disperso (ou seja, sem controle, com controle gerencial ou com controle diluído)".

A imensa diferença entre o percentual mínimo e máximo de participação conjunta detida pelos cinco maiores acionistas das companhias brasileiras listadas no Novo Mercado, ressalta, por outro lado, a diversidade existente entre as companhias integrantes do grupo objeto de estudo. O menor percentual de participação, identificado na companhia BR Malls Participações S.A., que declarou existir apenas um acionista com participação relevante classificado como não controlador, detentor de, aproximadamente, 4,99\% do capital social total, revela a existência de companhias de capital pulverizado no mercado brasileiro, ainda que em um ambiente de predominante concentração societária.

Tal como no caso da BR Malls, altos índices de dispersão acionária também podem ser identificados em outras companhias. Seguindo com a análise das participações detidas em conjunto pelos cinco maiores acionistas de cada companhia, foram identificadas 34 empresas $(26,36 \%$ do total de companhias analisadas) para as quais todos os acionistas foram classificados como não controladores, ou seja, 26,36\% das companhias listadas no Novo Mercado possuem estrutura de propriedade acionária pulverizada.

Dentre as 34 companhias referidas acima, contatou-se que os percentuais de participação detidos, em conjunto, pelos seus maiores acionistas variam entre 4,99\% e 77,57\%, sendo que (i) 1 companhia apresentou participação total inferior a 10\%: BR Malls Participações S.A. (4,99\%); (ii) 3 apresentaram participação total igual ou superior a $10 \%$ e inferior a 20\%: Even Construtora e Incorporadora S.A. (10,26\%), Gafisa S.A. (11,1\%) e Cia. Hering (19,84\%); (iii) 8 apresentaram participação total igual ou superior a $20 \%$ e inferior a 30\%: HRT Participações em Petróleo S.A. (20,07\%), Anhanguera Educacional Participações S.A. (20,84\%), BM\&Fbovespa S.A. Bolsa de Valores Mercadorias e Futuros $(22,16 \%)$, Valid Soluções e Serviços de Segurança em Meios de Pagamento e Identificação S.A. (22,98\%), CETIP S.A. - Mercados Organizados (25,37\%), PDG Realty S.A. Empreendimentos e Participações $(25,77 \%)$, Totvs S.A. (27,53\%); Iochpe Maxion S.A. 
$(28,11 \%)$ e Embraer S.A. (29,71\%); (iv) 5 apresentaram participação total igual ou superior a $30 \%$ e inferior a 40\%: Kroton Educacional S.A. (30,95\%), Lojas Renner S.A. $(32,3 \%)$, Eternit S.A. (35,52\%), Estácio Participações S.A. (35,57\%) e Brasil Pharma S.A. (35,86\%); (v) 6 apresentaram participação total igual ou superior a $40 \%$ e inferior a 50\%: Bematech S.A. (40,26\%), BRF S.A. (40,32\%), BR Properties S.A. (41,98\%), Diagnósticos da América S.A. (48,7\%), Ultrapar Participações S.A. $(49,45 \%)$ e Vanguarda Agro S.A. (49,84\%); (vi) 3 apresentaram participação total igual ou superior a 50\% e inferior a 60\%: Ideias Net S.A. (52,03\%), Restoque Comércio e Confecções de Roupas S.A. (54,21\%); e Metalfrio Solutions S.A. (59,76\%); Participações S.A. (35,57\%) e Brasil Pharma S.A. (35,86\%); (vii) 6 apresentaram participação total igual ou superior a $60 \%$ e inferior a $70 \%$ : CR2 Empreendimentos Imobiliários S.A. (61,01\%), LPS Brasil - Consultoria de Imóveis S.A. (61,3\%), Paranapanema S.A. (61,75\%), Tempo Participações S.A. (64,67\%), Log-in Logística Intermodal S.A. $(65,46 \%)$, Technos S.A. $(65,99 \%)$, e (viii) as 2 companhias restantes apresentaram participação total superior a 70\%: Viver Incorporadora e Construtora S.A. $(72,31 \%)$ e Lupatech S.A. $(77,57 \%)$.

Ainda que a participação conjunta detida pelos cinco maiores acionistas das companhias indicadas acima seja, em alguns casos, superior à metade do capital social, consideramos, para fins deste trabalho, que esses acionistas não estavam alinhados a ponto de deterem o controle compartilhado da companhia em questão, já que não foram indicados como acionistas controladores no respectivo Formulário de Referência. No entanto, nota-se que os índices de dispersão apresentados por companhias de capital pulverizado poderiam ser mais expressivos. Tal constatação demonstra o quanto o volume de participantes do mercado de capitais ainda pode ser expandido.

Em contraponto, foram identificadas diversas companhias com alto grau de concentração acionária entre seus cinco maiores acionistas, independentemente de todos integrarem ou não o bloco de controle, posto que praticamente a totalidade do capital social dessas companhias se mostrou concentrada nas mãos desse seleto grupo de acionistas - tal como no caso da Ecorodovias Infraestrutura e Logística S.A., para a qual a soma das participações detidas por seus únicos três acionistas apontados como acionistas controladores e/ou detentores de participação superior a 5\% do capital social total resultou no total aproximado de $99,91 \%$ do capital social total.

A análise da distribuição de capital acima evidencia claramente a histórica concentração da propriedade acionária nas companhias brasileiras e a realidade híbrida das 
companhias listadas no Novo Mercado. Resultado semelhante pôde ser identificado nas seguintes companhias, cujo total da participação societária detida pelos cinco maiores acionistas em conjunto é superior a 80\%: Vigor Alimentos S.A. (97,15\%); Cyrela Commercial Properties S.A. Empreendimentos e Participações (84,07\%); Profarma Distribuidora de Produtos Farmacêuticos S.A. (82,53\%); TPI - Triunfo Participações e Investimentos S.A. (81\%), e CCX Carvão da Colômbia S.A. (80,96\%).

Ainda sobre essa análise, a presente pesquisa foi direcionada para a apuração das participações detidas exclusivamente pelos acionistas identificados como controladores, desconsiderando-se, portanto, os percentuais de participação indicados pelas companhias nos respectivos Formulários de Referência para aqueles acionistas que, embora detentores de participação superior a $5 \%$ do capital social, não forma classificados como detentores de controle sobre as atividades sociais, conforme resultado apresentado na coluna Total Controle, da Tabela 2 (Apêndice B).

No que se refere à participação detida, em conjunto, pelos acionistas classificados como controladores, foram identificadas 67 (51,94\%) companhias com participação controladora total superior a 50\% do capital social, independentemente de tal participação ser detida por único acionista ou na forma compartilhada. Tais participações controladoras e majoritárias variam de 78,87\% a 50,26\%, representando uma média de participação conjunta majoritária e controladora aproximada de $60 \%$ do capital social.

Portanto, observando-se que aproximadamente $51,94 \%$ do total de companhias analisadas são claramente controladas por acionista ou grupo de acionistas detentores de participação societária majoritária, é inegável a assertiva de que a estrutura concentrada de propriedade do capital ainda é predominante entre as companhias brasileiras, em especial naquelas listadas no segmento do Novo Mercado.

Ao admitir que esse percentual não representa maioria esmagadora das companhias listadas no Novo Mercado e analisar tais resultados à luz dos estudos apresentados no capítulo anterior sobre a propriedade acionária das companhias brasileiras, resta claro e inegável a ocorrência de um movimento de dispersão na base acionária das companhias brasileiras. No entanto, observando que a dispersão é identificada em grau expressivamente inferior ao identificado em companhias listadas nos Estados Unidos ou no Reino Unido, conforme apresentado acima, torna-se importante verificar a existência de controle societário interno detido por acionistas das demais companhias, de modo a 
distinguir a amostragem de companhias com propriedade acionária dispersa entre companhias de capital pulverizado e companhias de capital relativamente pulverizado.

Ainda sobre a análise da participação detida, em conjunto, pelos acionistas classificados como controladores, foram identificadas 28 companhias que reconhecem a existência de um acionista controlador e/ou integrante de grupo de acionistas controladores das atividades sociais, ainda que estes sejam, em conjunto, detentores de participação societária total inferior à maioria do capital social; ou seja, aproximadamente $21,71 \%$ do total de companhias listadas no Novo Mercado possui o controle de suas atividades sociais concentrado nas mãos de acionista(s) detentor(es) de participação inferior à maioria do capital social total e, portanto, poderiam ser classificadas como companhias com estrutura de propriedade acionária relativamente pulverizada, nas quais existe um controle societário interno não majoritário ${ }^{32}$.

A análise de cada uma das 28 companhias destacadas permite identificar uma média de participação conjunta controladora e não majoritária correspondente a 32,06\% do capital social, sendo que: (i) 1 possui participação controladora correspondente a percentual inferior a $10 \%$ do capital social total: Brasil Insurance Participações e Administração S.A. $(6,48 \%$, detidos por um único acionista classificado como controlador $^{33}$ ); (ii) 3 possuem participação controladora total igual ou superior a $10 \%$ do capital social e inferior a 20\%: Iochpe Maxion S.A. (12,3\%), Rossi Residencial S.A. $(15,81 \%)$ e Brasil Brokers Participações S.A. (16,45\%); (iii) 5 possuem participação controladora total igual ou superior a $20 \%$ do capital social e inferior a 30\%: Raia Drogasil S.A. (21,23\%), ALL América Latina Logística S.A. (22,66\%), Equatorial Energia S.A. $(22,94 \%)$, Qualicorp S.A. $(25,4 \%)$ e Cyrela Brazil Realty S.A. Empreendimentos e Participações (28,81\%); (iv) 11 possuem participação controladora total igual ou superior a $30 \%$ do capital social e inferior a 40\%: BHG S.A. - Brazil Hospitality Group (30,18\%),

\footnotetext{
${ }^{32}$ Com o objetivo de eliminar eventuais inconsistências do universo de dados sob análise, as seguintes companhias foram desconsideradas do grupo de companhias com total de participação controladora inferior a $50 \%$, posto que, embora o total indicado na coluna Total Controle da Tabela 2 seja inferior ao referido percentual, foram identificados, durante a análise das informações divulgadas pelas companhias nos itens 15.1 e 15.2 dos respectivos Formulários de Referência, outros acionistas controladores com participação societária relevante, de modo que a participação total dos acionistas controladores resultaria, em conjunto, em participação majoritária - razão pela qual essas companhias foram computadas no cálculo de companhias com controle majoritário, conforme apresentado acima e ressaltado na própria Tabela 2: Marisa Lojas S.A.; Portobello S.A., e Unicasa Indústria de Móveis S.A.

${ }^{33}$ Dentre as 28 companhias nas quais foram identificadas participação controladora não majoritária, oito possuem um único acionista declarado como controlador: Brasil Insurance Participações e Administração S.A. (6,48\%); Equatorial Energia S.A. (22,94\%); Qualicorp S.A. (25,4\%); MRV Engenharia e Participações S.A. (33\%); Minerva S.A. (34,9\%); Indústrias Romi S.A. (37,86\%); International Meal Company Holdings S.A. $(39,75 \%)$; e Direcional Engenharia S.A. $(40,29 \%)$.
} 
Linx S.A. (30,23\%), Localiza Rent a Car S.A. (30,73\%), MRV Engenharia e Participações S.A. (33\%), Marfrig Alimentos S.A. (33,12\%), Minerva S.A. (34,9\%), Mills Estrutura e Serviços de Engenharia S.A. (35,5\%), Aliansce Shopping Centers S.A. (37,41\%), Indústrias Romi S.A. (37,86\%), Brasilagro - Companhia Brasileira de Propriedades Agrícolas (39,64\%) e International Meal Company Holdings S.A. (39,75\%); e (v) 8 possuem participação controladora total igual ou superior a $40 \%$ do capital social e inferior a 50\%: Direcional Engenharia S.A. (40,29\%), T4F Entretenimento S.A. (40,44\%), Hypermarcas S.A. (40,63\%), Magnesita Refratários S.A. (41,22\%), Cyrela Comercial Properties S.A. Empreendimentos e Participações (43,23\%), JBS S.A. (43,6\%), Brookfield Incorporações S.A. (46,77\%) e Companhia de Locação das Américas (47,02\%).

Embora a identificação de quantidade significativa de companhias com controle societário não majoritário demonstre sensível dispersão da base acionária das companhias abertas brasileiras e evidencie um tímido movimento de mudança na tradicional estrutura de concentração extrema do poder de controle e domínio familiar sobre as companhias abertas brasileiras, nota-se que a histórica valorização do poder de controle pelo mercado brasileiro permanece arraigada entre a grande maioria das companhias abertas brasileiras, conforme demonstrado nos dados apurados.

Pelos dados apurados, identificou-se que as companhias listadas no Novo Mercado possuem participação média de 34,16\% do capital social detida pelo maior acionista, aumentada para $51,44 \%$, se considerada a participação conjunta detida pelos três maiores, e $56,33 \%$ para os cinco maiores acionistas.

A partir da análise da estrutura de distribuição acionária das companhias listadas no Novo Mercado, conforme apurada neste estágio da pesquisa, é possível concluir que a estrutura concentrada da propriedade do capital social ainda é predominante entre as companhias brasileiras, visto que, no universo de 129 companhias abertas listadas no Novo Mercado, 95 (73,64\%) possuem controle societário definido, das quais 67 (51,94\%), classificadas com propriedade acionária concentrada, estão sob controle majoritário, e 28 $(21,71 \%)$, classificadas com propriedade acionária relativamente pulverizada, encontramse sob a influência de controle não majoritário, restando apenas 34 (26,36\%) com estrutura acionária pulverizada, ou seja, sem controle definido. 
É justamente pelo fato de ainda ser predominante a concentração do poder de controle entre as companhias abertas brasileiras que o estudo do instituto do controle societário permanece como importante questão a ser estudada pelos operadores do Direito. A existência de sociedades com controle societário inferior à maioria do capital social é constatação extremamente relevante; o instituto do controle minoritário, cuja existência comprovou-se empiricamente, será objeto de estudo detalhado no Capítulo 4 da presente dissertação.

Vale destacar que os capítulos a seguir apresentarão os demais resultados da pesquisa empírica realizada, exclusivamente, no âmbito das informações apuradas sobre o universo de companhias nas quais é inexistente o controle majoritário definido (seja por meio de participação majoritária individual seja pela estrutura compartilhada titular da maioria do capital social), ou seja, serão objeto das análises apresentadas, a seguir, apenas as companhias de propriedade acionária dispersa, conforme classificação proposta no presente estudo.

Para mais detalhes sobre os dados e resultados apresentados neste Capítulo 4.2, vide Tabela 2 (Apêndice B).

\subsection{Companhias sem Controle Majoritário}

A última etapa da pesquisa empírica ora descrita foi realizada exclusivamente sob a ótica daquelas companhias listadas no Novo Mercado em que a figura de um acionista, ou bloco de acionistas, detentor do controle majoritário é inexistente. Tal separação foi adotada com o propósito de restringir a amostra de companhias sujeitas à análise e voltar a atenção do presente estudo à estrutura de distribuição do capital das companhias sem controle majoritário.

A identificação do instituto do poder de controle nas sociedades por ações com controle majoritário parece ser tarefa simples quando comparada à identificação do controle não majoritário. Como largamente propagado pela doutrina societária, o controle majoritário é exercido a partir da titularidade de ações com direito a voto detidas por acionista titular da maioria do capital votante, sendo, portanto, facilmente identificadas as 
companhias nas quais existe a figura de acionista ou grupo de acionistas detentores do controle interno majoritário ${ }^{34}$.

Por outro lado, quando se trata da possibilidade de existência de um controle interno não majoritário, grande divergência pode ser observada na doutrina societária sobre o tema, tal como será apresentado no Capítulo 4. Por essa razão, a presente etapa da pesquisa empírica buscou constatar elementos que proporcionem melhor visualização da estrutura da propriedade acionária das companhias nas quais não existe controle majoritário definido.

A partir do entendimento do perfil dos acionistas, bem como do grau de dispersão do capital social dessas companhias sem controle majoritário, buscar-se-á identificar características que facilitem a diferenciação de acionistas detentores do poder de controle dentre as companhias analisadas nesta etapa, de modo a proporcionar melhor compreensão sobre o instituto do controle minoritário e sua configuração em companhias listadas no Novo Mercado.

Para tanto, esta última etapa da pesquisa considerou apenas o universo composto pelas 62 companhias listadas no Novo Mercado e sem controle majoritário - conforme mostradas no Capítulo 3.2 -, analisadas sob três aspectos: (i) identificação do perfil dos acionistas titulares de participação nas companhias objeto de estudo e do grau de dispersão acionária da respectiva companhia investida; (ii) análise das principais disposições dos acordos de acionistas arquivados nas sedes sociais das companhias sem controle majoritário; e (iii) verificação da adoção de cláusulas de proteção à dispersão acionária nos estatutos sociais de tais companhias.

\subsubsection{Perfil dos Acionistas e Grau de Dispersão}

Com os propósitos de identificar o perfil dos acionistas titulares de participação nas companhias sem controle majoritário e verificar o grau de dispersão acionária de tais companhias, foram levantadas as informações divulgadas pelas companhias no item 15.3 dos Formulários de Referência até 31 de maio de 2013. Nos termos da ICVM 480, a

\footnotetext{
${ }^{34}$ Recai sobre o tema discussão doutrinária sobre a necessidade de configuração do uso efetivo do poder de controle para a caracterização do acionista controlador majoritário, à luz do disposto no artigo 116 da Lei das S.A., conforme se apresentará a adiante.
} 
companhia emissora deve prestar no referido item informações atualizadas sobre a distribuição de seu capital social, detalhando, com base na última assembleia geral de acionistas realizada, a quantidade de acionistas pessoas físicas, pessoas jurídicas e investidores institucionais, bem como a quantidade de ações em circulação ${ }^{35}$.

Os referidos dados foram consolidados nas Tabelas 3 e 3.1 (Apêndice C). As 62 companhias de propriedade acionária dispersa analisadas, conforme identificadas na etapa descrita no Capítulo 3.2, foram divididas em dois grupos, a saber: Grupo A: companhias de propriedade acionária relativamente pulverizada, ou seja, nas quais, embora a figura de um acionista controlador majoritário seja inexistente, a presença de acionista(s) detentor(es) do poder de controle foi reconhecida pela própria companhia, quando da divulgação de informações ao mercado, como apurado na análise objeto do Capítulo 3.2; e Grupo B: companhias com propriedade acionária pulverizada, isto é, nas quais, após a análise apresentada no Capítulo 3.2, não foi identificada a existência de acionista(s) detentor(es) do poder de controle.

Por meio da análise das informações, das 28 companhias que integram o Grupo A, representativas de $21,71 \%$ do total de companhias listadas no Novo Mercado e 45,16\% das companhias sem controle majoritário, identificou-se que em apenas duas (Companhia de Locação das Américas e International Meal Company Holdings S.A.) a quantidade de acionistas pessoas físicas não é superior à dos demais tipos de acionistas, sendo predominante a presença de acionistas investidores institucionais. Nas 26 companhias

\footnotetext{
${ }^{35}$ Nos termos do Anexo 24 à ICVM 480 (Conteúdo do Formulário de Referência), o item 15.3 deve ser preenchido com as seguintes informações: “15.3: Em forma de tabela, descrever a distribuição do capital, conforme apurado na última assembleia geral de acionistas: a. número de acionistas pessoas físicas; b. número de acionistas pessoas jurídicas; c. número de investidores institucionais; d. número de ações em circulação, por classe e espécie." Por meio do Ofício-Circular CVM/SEP 1/2013, a CVM divulga às companhias abertas orientação geral sobre o preenchimento do Formulário de Referência. Ao tratar sobre o preenchimento do item 15.3, do formulário, esclarece a autarquia: "As quantidades de pessoas físicas e jurídicas acionistas do emissor (letras 'a' e 'b') deverão ser apuradas sem a exclusão dos acionistas que tenham sido informados nos itens 15.1 e 15.2 como acionistas controladores ou detentores de $5 \%$ ou mais das ações ordinárias ou preferenciais. Para os efeitos deste item, os fundos e clubes de investimento devem ser classificados como pessoas jurídicas. O emissor também deverá informar a quantidade aproximada de investidores institucionais que estão incluídos nessa categoria de investidores (letra 'c'). (...) O número de ações em circulação, por classe e espécie, e as quantidades de pessoas físicas e jurídicas e de investidores institucionais deverão ser apuradas com base nas informações constantes dos livros sociais da companhia e das informações prestadas pela instituição prestadora de serviços de custódia." Disponível em: <http://www.c vm.gov.br/port/atos/oficios/Of\%C3\%ADcio\%20Circular\%20SEP\%20n\%C2\%BA\%2001-2013\%20-\%20Orie nta\%C3\%A7\%C3\%B5es\%20Gerais.pdf >. Acesso em: 11 jan. 2013. Vale destacar que a CVM não esclarece, no entanto, se os números indicados no item 15.3 devem ser referentes apenas aos acionistas presentes na respectiva assembleia geral, ou se a última assembleia geral realizada deverá servir apenas como referência para o levantamento de dados na data de sua realização. Nesse contexto, cumpre esclarecermos que, para este trabalho, será considerada a última hipótese, assumindo-se, portanto, que os dados apresentados pelas companhias correspondem à totalidade do capital social, conforme apurado pelas instituições de custódia na data de realização da última assembleia geral.
} 
restantes, a base acionária é predominada por acionistas pessoas físicas, sendo que a representatividade desse grupo entre os acionistas das companhias com controle não majoritário varia de $43,15 \%$ a $93,48 \%$ do total de acionistas e resulta em uma média de representatividade correspondente a $71,4 \%$.

O mesmo resultado foi identificado entre as 34 companhias que integram o Grupo B (26,36\% do total de companhias listadas no Novo Mercado e 54,84\% das companhias sem controle majoritário). Com exceção de duas sociedades, Brasil Pharma S.A. e Embraer S.A. (nas quais predominam acionistas institucionais e pessoas jurídicas, respectivamente), os acionistas pessoas físicas também predominam a base acionária, sendo que a representatividade desse grupo de acionistas nas companhias sem controle definido varia de $41,13 \%$ a $97,17 \%$ do total de acionistas e resulta em uma média de representatividade correspondente a $74,83 \%$.

A segunda categoria de acionistas com maior presença nas companhias com controle não majoritário (Grupo A) é a de acionistas classificados como investidores institucionais. Conforme orientação divulgada pela CVM às companhias emissoras, são investidores institucionais:

[...] os participantes do mercado que atuam na gestão de recursos de terceiros. Estão incluídas nessa categoria, entre outras, as sociedades de seguro, previdência e capitalização, fundos mútuos de investimento em ações, fundos de investimentos imobiliários, fundos de previdência privada, fundos de plano de benefícios e sociedades seguradoras e instituições de caráter filantrópico. ${ }^{36}$

A representatividade de investidores institucionais entre as companhias do Grupo A varia de 0 a $62,08 \%$ do total de acionistas e corresponde a uma representatividade média de 20,85\%, enquanto os acionistas pessoas jurídicas são menos presentes, com representatividade que varia de $0,64 \%$ a $47,5 \%$ do total de acionistas, correspondendo a uma representatividade média de $7,75 \%$.

Já nas companhias do Grupo B (sem controle definido), a participação de acionistas investidores institucionais e pessoas jurídicas é inversa. O grupo de acionistas pessoas jurídicas ocupa o segundo lugar com maior presença entre os acionistas das companhias do Grupo B, com representatividade que varia de 0 a $38,83 \%$ do total de acionistas e corresponde a uma representatividade média de 13,51\%, enquanto os acionistas

\footnotetext{
${ }^{36}$ Cf. Item 9.2.15.c, do Ofício-Circular CVM/SEP 1/2013. Disponível em: <http://www.cvm.gov.br/ port/atos/oficios/Of\%C3\%ADcio\%20Circular\%20SEP\%20n\%C2\%BA\%2001-2013\%20-\%20Orienta\%C3\% A7\%C3\%B5es\%20Gerais.pdf>. Acesso em: 11 jan. 2013.
} 
institucionais apresentam menor representatividade nas companhias sem controle definido, com representatividade que varia de 0 a 39,4\% do total de acionistas e corresponde a uma representatividade média de $11,74 \%$.

A partir desses dados, identifica-se que, na data base das informações analisadas: (i) as companhias com controle não majoritário (Grupo A) possuíam, em média, o total de 3.838 acionistas, sendo 3.152 acionistas pessoas físicas, 435 investidores institucionais e 252 pessoas jurídicas; (ii) as companhias sem controle definido (Grupo B) possuíam, em média, o total de 8.164 acionistas, sendo 6.646 acionistas pessoas físicas, 905 pessoas jurídicas e 612 investidores institucionais.

A quantidade de acionistas identificada nas companhias do Grupo B em número expressivamente superior à apurada no Grupo A tende a demonstrar maior grau de dispersão do capital social nas companhias sem controle definido (Grupo B). No entanto, considerando que os números acima representam apenas a quantidade total de acionistas e não suas respectivas participações no capital social, a adoção de outro critério se faz necessária para verificar o efetivo grau de dispersão do capital social entre os acionistas das companhias sem controle majoritário.

Nesse contexto, vale examinar a distribuição do capital social de tais companhias não apenas sob a ótica da quantidade de acionistas e seus diferentes perfis, mas, também, das respectivas participações detidas no capital social.

Com o objetivo de proporcionar certa dispersão de ações no mercado, em geral, garantindo maior liquidez aos investimentos e maior segurança a acionistas minoritários, o Regulamento de Listagem do Novo Mercado estabelece em seus itens 2.1 e 3.1 que, para ser admitida no Novo Mercado, uma companhia emissora deve manter percentual mínimo de ações em circulação correspondente a, pelo menos, $25 \%$ do total do capital social da companhia, durante o período em que os valores mobiliários de sua emissão permanecerem registrados para negociação no Novo Mercado.

Conforme esclarecimentos sobre o tema, divulgados pela BMF\&BOVESPA, por meio do Ofício-Circular 059/2012-DP, de 13 de novembro de 2012, a obrigação de observar o percentual mínimo de ações em circulação (free float) tem o objetivo de

proporcionar condições mínimas para exercício, pelos acionistas não controladores, de prerrogativas e direitos previstos na legislação societária e regulamentação em vigor que dependam da titularidade de determinada participação acionária. A referida exigência visa a elevar a probabilidade de 
existência de acionistas não controladores ativos, propiciando condições mínimas para que estes efetivamente se organizem e exerçam os direitos assegurados pela legislação e regulamentação em vigor [...]. Adicionalmente, a exigência de Percentual Mínimo de Ações em Circulação reflete a preocupação da BM\&FBOVESPA com a negociação ou liquidez das ações das companhias listadas $[\ldots] .^{37}$

Nesse contexto, a análise do percentual do capital social sob livre negociação na bolsa de valores surge como alternativa favorável a uma boa identificação do grau de dispersão acionária das companhias sem controle majoritário. Dessa forma, foram levantados os percentuais de ações em circulação de cada companhia, conforme dados divulgados no mesmo item 15.3 dos respectivos Formulários de Referência.

Nos termos do disposto no artigo 62 da ICVM 480, as ações em circulação devem corresponder a todas as ações de emissão de determinada companhia, excluídas as ações que sejam de titularidade de acionista controlador, de pessoas a ele vinculadas ${ }^{38}$, dos administradores da companhia emissora, e, ainda, as ações mantidas em tesouraria.

Definição semelhante é estabelecida para as ações em circulação no Regulamento de Listagem do Novo Mercado, em seu item 2.1:

\footnotetext{
"Ações em Circulação" significa todas as ações emitidas pela Companhia, excetuadas as ações detidas pelo Acionista Controlador, por pessoas a ele vinculadas, por Administradores da Companhia, aquelas em tesouraria e preferenciais de classe especial que tenham por fim garantir direitos políticos diferenciados, sejam intransferíveis e de propriedade exclusiva do ente desestatizante. (grifo nosso)
}

A partir do conceito de ações em circulação e da obrigatoriedade de manutenção de, pelo menos, $25 \%$ do total do capital social em circulação, acredita-se ser possível apurar, com maior precisão, o grau de dispersão acionária das companhias objeto de análise. Dessa forma, com base nas informações divulgadas por tais companhias, no item 15.3 de seus Formulários de Referência, foram levantados os percentuais correspondentes às ações em circulação de emissão das companhias dos Grupos A e B, conforme indicado na coluna Ações em Circulação das Tabelas 3 e 3.1 (Apêndice C).

\footnotetext{
${ }^{37}$ Vale mencionar que a obrigatoriedade de percentual mínimo de ações em circulação também é estabelecida nos Regulamentos de Listagem do Nível 2 e do Nível 1 de Governança Corporativa, sendo que, no referido Ofício-Circular, a BMF\&FBOVESPA recomenda que as companhias mantenham percentual de ações em circulação superior aos $25 \%$ do capital social, "conferindo maior liquidez às ações e flexibilidade na negociação por parte dos Acionistas Controladores (...)".

${ }^{38}$ Nos termos do parágrafo único do artigo 62, da ICVM 480, deve-se entender por pessoa vinculada "a pessoa natural ou jurídica, fundo ou universalidade de direitos, que atue representando o mesmo interesse da pessoa ou entidade a qual se vincula".
} 
Os percentuais de ações em circulação apurados nas companhias do Grupo A variam de $27,28 \%$ a $100 \%$ e correspondem a um percentual médio de $61,43 \%$. No entanto, considerando que a análise dos percentuais de ações em circulação também pode ser utilizada como método de confirmação da existência de acionistas titulares do poder de controle, posto que, por exclusão, subentende-se que a parcela das ações não incluídas no grupo de ações em circulação pode integrar, em grande parte, um bloco de controle, os percentuais identificados no item 15.3 foram confrontados com os dados da coluna Total Controle da Tabela 2 (Apêndice B), que consolidam a participação total identificada como controladora na análise realizada no Capítulo 3.2.

Também pelos dados apurados no referido Capítulo 3.2, foram identificadas as 28 companhias com acionista(s) controlador(es) detentor(es) de participação societária total inferior a 50\% do capital social, todas, portanto, integrantes do Grupo A. A partir disso, é possível presumir que os percentuais de ações em circulação dessas companhias deveriam corresponder a índice igual ou superior a 50\%. No entanto, considerando que a definição de ações em circulação abrange não apenas o acionista controlador como também as ações mantidas em tesouraria, pessoas vinculadas ao controlador e membros da administração (já que estes podem exercer seus direitos de voto de forma alinhada), o percentual de ações em circulação poderia atingir percentual inferior a 50\%, mas sem grande variação desse índice, sendo aceitável, para fins do presente trabalho, percentuais de ações em circulação correspondentes a até $30 \%$ do capital social total.

Dessa forma, com o objetivo de apurar eventuais inconsistências nas informações divulgadas pelas companhias analisadas, optou-se, para fins desta etapa da pesquisa, desconsiderar do Grupo A as companhias que apresentaram percentuais de ações em circulação em descasamento com o racional apresentado acima, a saber: Cyrela Commercial Properties S.A. Empreendimentos e Participações (27,28\%) e Indústrias Romi S.A. $(100 \%)^{39}$. Após a referida exclusão, identificou-se que os percentuais de ações em

\footnotetext{
${ }^{39}$ A companhia Indústrias Romi S.A. divulgou erroneamente seu percentual de ações em circulação, posto que, no mesmo Formulário de Referência, reconheceu a existência de minoria acionária detentora do poder de controle, não apenas nos itens 15.1 e 15.2, como também no próprio item 8 (Grupo Econômico), ao apresentar organograma específico com os percentuais de participação dos controladores no capital social da companhia. Nos termos do referido organograma, a companhia possuía 48,48\% de suas ações em circulação, enquanto o percentual de $47,42 \%$ do capital social total estava concentrado nas mãos do grupo controlador: Fenix Empreendimentos S.A.; membros das famílias Romi e Chiti, e Fundação Romi. Vale destacar que, embora o percentual de ações em circulação da companhia Cyrela Commercial Properties S.A. Empreendimentos e Participações esteja fora do padrão considerado para análise do grau de dispersão, a composição do capital social indicada nos itens 15.1 e 15.2 de seu Formulário de Referência demonstra a
} 
circulação das 26 companhias restantes do Grupo A variam de, aproximadamente, 42,03\% a 79,19\%, representando percentual médio de ações livres correspondente a 61,26\%.

Por meio da análise dos dados identificados para as companhias do Grupo B, conforme apresentados nas Tabelas 3 e 3.1 (Apêndice C), verificou-se que o percentual de ações em circulação varia de $0,13 \%$ a $100 \%$ do capital social total, correspondendo a um percentual de dispersão médio de $88,63 \%$. Diante de tais percentagens, optou-se por utilizar o mesmo método de seleção utilizado para a análise dos dados das companhias do Grupo A.

Uma vez que foram classificadas no Grupo B apenas as 34 companhias nas quais não foi reconhecida a existência de qualquer acionista titular do poder de controle, ou seja, companhias para as quais o total indicado na coluna Total Controle da Tabela 2 (Apêndice B) correspondeu a zero, optou-se por considerar, nesta etapa, apenas os percentuais de dispersão que variassem de $70 \%$ a $100 \%$ do capital social total, sendo, dessa forma, desconsideradas quatro companhias, a saber: Viver Incorporadora e Construtora S.A. $(0,13 \%)^{40}$; Metalfrio Solutions S.A. (40,24\%); Vanguarda Agro S.A. (66,8\%); e Totvs S.A. $(68,5 \%)$.

Após essa exclusão, identificou-se que os percentuais de ações em circulação das 30 companhias remanescentes no Grupo B variam de, aproximadamente, 74,2\% a 100\%, representando percentual médio de ações livres correspondente a 94,59\%, o que evidencia a existência de companhias com capital realmente pulverizado no mercado de capitais brasileiro. Nesse contexto, vale citar as companhias nas quais não foram identificados quaisquer acionistas controladores e cujos percentuais de ações em circulação correspondem a $100 \%$ do capital social total, ou a valor bastante aproximado: Embraer S.A. (100\%); Gafisa S.A. (100\%); Ideiasnet S.A. (100\%); LPS Brasil - Consultoria de Imóveis S.A. (100\%); Lupatech S.A. (100\%); Restoque Comércio e Confecções de Roupas S.A. (100\%); Tempo Participações S.A. (100\%); Valid Soluções e Serviços de Segurança em Meios de Pagamento e Identificação S.A. (100\%); Paranapanema S.A. (99,9\%); Lojas Renner S.A. (99,63\%); Brasil Pharma S.A. (99,59\%); e BR Properties S.A. (99,03\%).

existência de um controle minoritário na companhia, razão pela qual os dados da companhia foram considerados nas demais análises apresentadas neste Subtítulo 3.3.1.

${ }^{40}$ Supõe-se que a companhia divulgou erroneamente seu percentual de ações em circulação, posto que no mesmo Formulário de Referência reconheceu, nos itens 15.1 e 15.2, que 27,69\% de seu capital social estava disperso no mercado, classificando tal percentual como detido por "outros". 
A comparação da média final de ações em circulação identificada nas companhias integrantes dos Grupos A e B, 61,26\% e 94,59\% respectivamente, demonstra uma grande diferença na estrutura de propriedade do capital das companhias de cada grupo, restando evidente que estas não devem ser classificadas sem qualquer diferenciação, apenas como companhias sem controle majoritário. É importante que o aplicador do Direito Societário reconheça as diferentes realidades desses dois universos de companhias, considerando-as como integrantes de grupos diferentes tal como proposto no presente trabalho, de modo a atentar para as diferentes nuances de cada estrutura de organização.

Por outro lado, a diferença entre os percentuais apurados em cada grupo não pode ser suficiente para determinar um fator de distinção entre suas companhias. Há de se reconhecer a existência de uma tênue linha divisora das companhias integrantes dos diferentes grupos, como se pode verificar na confirmação das companhias objeto de análise, quando da comparação com os percentuais detidos pelos acionistas controladores de cada companhia.

A análise dos percentuais de ações em circulação levantados nas companhias sem controle definido (Grupo B) revelou dois pontos intersecção com os dados identificados nas companhias do Grupo A: o primeiro aparece nos percentuais de seis companhias, que variam de $66,8 \%$ a $77,66 \%$ do capital social $^{41}$, enquanto o segundo ponto é constatado no percentual de ações em circulação indicado pela Metalfrio Solutions S.A. (40,24\%).

O baixo percentual de ações em circulação indicado pela Metalfrio representa claro exemplo de uma zona cinzenta que divide as companhias com acionistas controladores não majoritários das que não possuem controle definido, impossibilitando a fixação de um determinado percentual de dispersão como critério único de distinção.

Conforme dados divulgados em seu Formulário de Referência, em 31 de maio de 2013, a referida companhia indicou, em seus itens 15.1 e 15.2, que apenas 1,53\% de seu capital social correspondia a ações mantidas em tesouraria, enquanto $38,71 \%$ de seu capital social estava literalmente disperso no mercado, tendo sido indicado sob titularidade de “outros". O restante do capital, remanescente aos $40,24 \%$ do capital social que se encontrava em circulação, restava sob titularidade de apenas três acionistas: Almond Tree LLC (27,94\%); Peach Tree LLC (26,56\%); e Bravia Capital Investimentos Ltda. (5,26\%), todos declarados como não controladores.

\footnotetext{
${ }^{41}$ Vanguarda Agro S.A. (66,8\%); Totvs S.A. (68,5\%); Bematech S.A. (74,2\%); Kroton Educacional S.A.
} (76,15\%); CR2 Empreendimentos Imobiliários S.A. (77,39\%), e Cia Hering (77,66\%). 
O menor acionista indicado, Bravia Capital Investimentos Ltda., é sociedade gestora de recursos independente que, embora não tenham sido divulgadas informações que comprovem eventual ligação direta com as demais acionistas, os três possuem denominações semelhantes entre eles e nos levam) ao questionamento sobre a possibilidade de integrarem o mesmo grupo. Ao observar as participações detidas nesses acionistas (participações indiretas na companhia), verifica-se apenas que ambos são totalmente controlados por sociedades estrangeiras distintas, cada uma delas controlada por um membro do Conselho de Administração da Metalfrio.

Considerando que os percentuais detidos por tais acionistas, em conjunto, poderiam resultar em participação majoritária $(54,5 \%)$, cogitou-se a possibilidade de exercício de controle via acordo de acionistas; no entanto, conforme informações divulgadas pela companhia à CVM, foi confirmada a inexistência de um acordo de acionistas que evidenciasse uma atuação conjunta.

A ambiguidade do caso Metalfrio e as demais intersecções entre os Grupos A e B, demonstram a necessidade de se analisar outras características das companhias sem controle majoritário que complementem a verificação da real inexistência de acionistas controladores e/ou a identificação de minoria acionária detentora do poder de controle. Nesse contexto, os próximos subtítulos deste Capítulo 3.3 apresentarão alternativas de critérios adicionais que podem garantir melhor reconhecimento de acionistas detentores do poder de controle em companhias sem controle majoritário.

Para mais detalhes sobre os resultados apresentados neste Subtítulo 3.3.1, vide Tabelas 3 e 3.1 (Apêndice C).

\subsubsection{Acordo de Acionistas - Principais Disposições}

Quando da celebração de um acordo de acionistas, as partes signatárias realizam um pacto parassocial, na medida em que convencionam sobre seus próprios interesses no âmbito de suas participações em determinada(s) sociedade(s), em complemento ao disposto nos instrumentos constitutivos que regulamentam tal(is) sociedade(s). 
Conforme bem definido por Lucena (2009, p. 1.130 e ss.):

O acordo de acionistas é um contrato que disciplina a conduta intersubjetiva dos
convenentes segundo seus interesses pessoais (uti singuli), em relação à
companhia de que são acionistas, assim operando como instrumento de
composição de grupos, visando a unidade do exercício do direito de voto nas
assembleias e/ou a negociabilidade das ações de que são titulares. [...] É o acordo
de acionista, em suma, um contrato nominado, parassocial, plurilateral e
preliminar.

Embora a doutrina não seja unânime quanto à abrangência das matérias objeto de convenção em acordos de acionistas, havendo correntes divergentes sobre a validade e eficácia de outras convenções além daquelas elencadas no artigo 118 da Lei das S.A. (compra e venda de ações, preferência para adquiri-las, exercício do direito de voto, e exercício do poder de controle) (LUCENA, 2009, p. 1.134 e ss.), a doutrina em geral se mostra unânime em relação à tipificação do acordo de acionistas com base nas matérias previstas no referido artigo, já que estas são frequentemente identificadas na prática societária.

Bertoldi (2006, p. 71), ao sumarizar as tipificações encontradas na doutrina, divide os acordos de acionistas entre (i) acordos de voto, que disciplinam sobre o exercício do direito de voto pelos acionistas contratantes, e (ii) acordos de bloqueio, que disciplinam sobre a negociabilidade das ações de propriedade de seus signatários, sendo a primeira espécie, acordos de voto, subdividida entre os acordos de comando (celebrados para o exercício do poder de controle) e acordos de defesa (celebrados para a defesa de direitos atribuídos em lei a acionistas não controladores).

No âmbito do presente trabalho, merecem destaque os acordos de comando, celebrados para a obtenção, manutenção e/ou o exercício do poder de controle, de modo que seus signatários, ao subordinarem suas vontades e direitos de voto à decisão unitária previamente estabelecida, restam enquadrados nos requisitos estabelecidos no artigo 116 da Lei das S.A. para a caracterização do acionista controlador.

Ao tratarem sobre as finalidades dos acordos celebrados para o exercício do direito de voto, concluem Teixeira e Guerreiro (1979, p. 310):

Podem constituir, primordialmente, um meio eficaz de consolidar a maioria, através da aglutinação de votos pulverizados [...]. Com isso, pode-se assegurar a estabilidade da administração da companhia, não só mediante a permanência de sua composição como também mediante a continuidade das diretrizes da gestão social, inclusive quanto à politica de distribuição de lucros [...]. 
Embora a celebração de acordos de comando resulte, na maioria dos casos identificados na prática societária, na consolidação de votos de acionistas que detenham, em conjunto, a maioria do capital votante, os recentes eventos de dispersão acionária e a atual configuração do mercado acionário brasileiro, tal como identificada nos capítulos anteriores, demandam análise mais abrangente dos acordos de comando, de modo a possibilitar a sua tipificação ainda que os signatários do acordo em questão não sejam, em conjunto, detentores da maioria do capital social votante.

Ora, se um acordo de acionistas for celebrado com o objetivo de exercício, de forma organizada, do controle de fato sobre a condução das atividades sociais, dispondo, inclusive, sobre a eleição da administração de determinada companhia, não teria sentido a classificação do acordo em questão como acordo de defesa, supostamente celebrado em garantia ao exercício dos direitos de seus signatários conferidos em lei a acionistas detentores de participação minoritária não relevante, pelo simples fato de não haver titularidade, por seus signatários, de participação correspondente à maioria do capital votante.

Conforme esclarecido por Bertoldi (2006, p. 77):

\begin{abstract}
A partir do acordo de comando, seus signatários viabilizam a tomada de controle da companhia, passando a influenciar diretamente na condução de seus rumos, seja através das deliberações assembleares, seja mediante a inegável influência que terão sobre os administradores por eles eleitos. Como não poderia deixar de ser, os signatários do acordo de comando, caracterizados como controladores da companhia, nos estritos termos do parágrafo único do art. 116 da Lei 6.404/76, deverão exercer o poder com o fim de fazer a companhia realizar o seu objeto social e ainda cumprir a função social, [...] respondendo pelos dados que porventura venham a causar em decorrência de abuso do poder.
\end{abstract}

Na mesma linha, Carvalhosa (2011a, p. 117) defende que, ao celebrarem acordo que verse sobre o exercício do poder de controle, seus signatários formam uma comunhão na qual convencionam a realização de reuniões prévias às deliberações a serem tomadas pelos órgãos da companhia, seja na esfera de assembleia geral seja na administrativa (conselho ou diretoria), e esclarece:

Nessa reunião prévia será decidido, pelo critério da maioria absoluta dos acionistas, o direcionamento dos votos a serem proferidos pelos convenentes em assembleia geral. E, em se tratando de matérias relevantes ou extraordinárias, a direção dos votos a serem dados pelos conselheiros e pelos diretores representantes dos acionistas signatários nas reuniões do conselho de administração e da diretoria, respectivamente. 
Vale destacar, ainda, o disposto nos parágrafos $8^{\circ}$ e $9^{0}$ do artigo 118 da Lei das S.A., introduzidos quando da reforma da Lei das S.A. pela Lei $\mathrm{n}^{\mathrm{o}} 10.303$, de 31 de outubro de 2001. O referido parágrafo $8^{\underline{0}}$ proíbe que o presidente da assembleia, ou do órgão de deliberação da companhia em questão, considere votos proferidos em infração ao disposto em acordo devidamente arquivado na sede social. Já o parágrafo $9^{0}$ estabelece instituto de mandato, conferindo aos signatários do acordo a prerrogativa de votar com as ações pertencentes a acionista ou membro do conselho ausente ou omisso.

Ambos os parágrafos admitem a existência dos acordos de acionistas na vida societária e conferem a tais acordos a força necessária para o exercício do poder de controle por seus signatários, ao reforçarem o cumprimento das avenças acordadas no âmbito das deliberações a serem tomadas pelos órgãos sociais - desde que, por óbvio, não sejam contrárias à lei, ao estatuto ou ao interesse social da companhia em questão.

Diante das características apresentadas, e considerando a possibilidade de existência de acionistas controladores organizados por meio de acordo que componha um bloco controlador não necessariamente detentor da maioria absoluta das ações com direito a voto, propõe-se no presente capítulo a análise dos acordos celebrados por acionistas de companhias listadas no Novo Mercado e sem controle majoritário, de modo a evidenciar a existência de acordos celebrados com o propósito de disciplinar o exercício do controle societário interno de tais companhias.

Ora, por entender-se que a existência do acordo de acionistas evidencia uma vontade ou busca dos signatários por situação de melhor posicionamento estratégico na companhia, a presente pesquisa foi direcionada à busca por elementos adicionais que pudessem favorecer tal identificação.

Para tanto, foram analisadas as principais cláusulas dos acordos de acionistas divulgados à CVM, nos termos do item 15.5 do Formulário de Referência de cada uma das 62 companhias listadas no Novo Mercado com propriedade acionária dispersa, nas quais não foi verificada a presença de acionista ou grupo de acionistas detentor de controle majoritário interno, conforme dados apresentados no Capítulo 3.2.

Nos termos do disposto na ICVM 480, as companhias emissoras devem descrever no referido item 15.5 as principais características de qualquer acordo de acionistas arquivado em sua sede social ou de acordo do qual controlador acionista seja parte e que 
regule sobre o exercício do direito de voto ou a transferência de ações da companhia emissora $^{42}$.

Nesse contexto, de modo a apresentar um panorama da estrutura e do perfil dos acordos celebrados por acionistas de companhias sem controle majoritário, foram levantadas as informações divulgadas tanto pelas companhias integrantes do Grupo A (com propriedade acionária relativamente pulverizada e nas quais, portanto, há controle interno não majoritário), como do Grupo B (com propriedade acionária pulverizada, sem controle definido), conforme apresentado no Subtítulo 3.3.1 e nos respectivos Formulários de Referência até 31 de maio de 2013.

As informações obtidas pelo levantamento acima foram consolidadas nas Tabelas 4 e 4.1 (Apêndice D), na qual se destaca a presença de quatro cláusulas principais comumente identificadas em acordos de acionistas, conforme prática societária: (i) cláusulas relacionadas ao exercício do direito de voto e poder de controle, subdivididas entre cláusulas referentes à exigência de voto afirmativo e cláusulas referentes à realização de reuniões prévias; (ii) cláusulas referentes à indicação de administradores, subdivididas de acordo com os membros sujeitos a indicação (diretores e/ou conselheiros); (iii) cláusulas referentes a restrições à transferência de ações, subdivididas por espécie de restrição, quais sejam, vedações a negociação e transferência por período de tempo (lockup), direito de preferência, direito de venda conjunta (tag along), e direito de exigir a venda (drag along); e (iv) cláusulas que determinam a vinculação dos membros da administração da companhia ao disposto no acordo em questão - as quais vão além do exigido da administração da companhia com relação ao cumprimento do disposto nos acordos de acionistas (conforme parágrafo $8^{\circ}$ do artigo 118 da Lei das S.A.).

Com base nas classificações apresentadas acima, buscou-se apurar, dentre as informações coletadas, a existência de convenções que evidenciassem arranjos de acordos de comando (referentes ao exercício do direito de voto e poder de controle, à indicação de administradores e à vinculação dos membros da administração) e arranjos de acordos de bloqueio (cláusulas que contenham restrições à transferência de ações).

\footnotetext{
${ }^{42}$ Conforme Anexo 24 à ICVM 480, o item 15.5 deve apresentar: "15.3: Com relação a qualquer acordo de acionistas arquivado na sede do emissor ou do qual o controlador seja parte, regulando o exercício do direito de voto ou a transferência de ações de emissão do emissor, indicar: a. partes; b. data de celebração; c. prazo de vigência; d. descrição das cláusulas relativas ao exercício do direito de voto e do poder de controle; e. descrição das cláusulas relativas à indicação de administradores; f. descrição das cláusulas relativas à transferência de ações e à preferência para adquiri-las; g. descrição das cláusulas que restrinjam ou vinculem o direito de voto de membros do conselho de administração; h. indicar alterações relevantes nas participações dos membros do grupo de controle e administradores do emissor; i. fornecer outras informações que o emissor julgue relevantes."
} 
Dentre as 36 companhias classificadas no Grupo B, apenas cinco declararam a existência de acordo de acionistas para fins do item 15.5 de seus Formulários de Referência, a saber: Anhanguera Educacional Participações S.A.; Even Construtora e Incorporadora S.A.; Kroton Educacional S.A.; Technos S.A.; e Ultrapar Participações S.A. Considerando que tais companhias não possuem controle definido e possuem alto grau de dispersão no mercado, o baixo número de acordos celebrados entre seus acionistas já era esperado.

Da análise dos acordos identificados nas companhias acima, foi possível verificar a ausência de cláusulas que poderiam evidenciar o compartilhamento do controle societário interno entre os acionistas signatários, exceto pelo acordo divulgado pela Ultrapar Participações S.A. Referido acordo, celebrado na esfera dos acionistas indiretos da companhia, prevê expressamente a organização e manutenção de um bloco definido e estável de acionistas, formado com o objetivo de defender seus interesses na qualidade de acionistas indiretos da Ultrapar Participações S.A.

Embora o acordo estabeleça, no âmbito da Ultra S.A. (maior acionista da Ultrapar Participações S.A., detentora de 23,67\% do capital social da companhia), a obrigatoriedade de realização de reuniões entre seus acionistas, previamente à realização de assembleias da Ultrapar Participações S.A., entende-se que esse arranjo representa apenas mecanismo de comando sobre as decisões da Ultra S.A., não se referindo ao exercício do controle sobre as atividades da companhia aberta da qual essa é acionista, já que não se trata de acordo celebrado entre acionistas diretos da Ultrapar.

Com relação às demais disposições objeto de análise, notou-se que, dentre os cinco acordos de acionistas identificados nas companhias do Grupo B: (i) duas possuem disposições referentes à indicação de membros do Conselho de Administração (Even Construtora e Incorporadora S.A. e Kroton Educacional S.A.) e (ii) três possuem restrições à transferência de ações, sendo que um estabelece apenas período de lock-up (Technos S.A.), outro disciplina apenas sobre direito de venda conjunta (Kroton Educacional S.A.), e o acordo da Anhanguera Educacional Participações S.A. disciplina sobre direitos de preferência, venda conjunta e de exigir a venda.

A análise das disposições referentes à indicação de membros da administração, presente nos acordos de acionistas da Even Construtora e Incorporadora S.A. e da Kroton Educacional S.A., mostrou que o acordo previa arranjo para garantir a indicação, por um dos signatários, ao conselho de pelo menos um membro, não tendo sido identificados 
elementos que garantissem a indicação da maioria dos membros do Conselho de Administração, como no caso da Ultra, que se acredita tratar apenas de acordo de defesa e não de comando.

Constatada a ausência de acordos de comando, no âmbito das companhias sem controle majoritário classificadas no Grupo B, foram analisadas as disposições constantes dos acordos de acionistas identificados entre as 28 companhias classificadas no Grupo A, quais sejam, aquelas com propriedade acionária relativamente dispersa, nas quais existe um acionista ou grupo de acionistas que, embora detentores de participação minoritária, classificaram-se como acionistas controladores, tal como detalhado no Capítulo 3.2.

Na análise das informações referentes às companhias integrantes do Grupo A, foram identificadas 20 companhias com acordos de acionistas $(71,43 \%$ do total de companhias do grupo), entre as quais apenas três possuem um único acionista classificado como controlador nos termos apresentados no Capítulo 3.2, a saber: Brasil Insurance Participações e Administração S.A., Minerva S.A., e Indústrias Romi S.A., enquanto nas demais companhias com acordos de acionistas, o controle societário interno é exercido de forma compartilhada.

Em relação às disposições dos acordos divulgados por Brasil Insurance Participações e Administração S.A., Minerva S.A., e Indústrias Romi S.A., notou-se que o acordo publicado pela companhia Minerva foi celebrado no âmbito das participações detidas em sua acionista controladora direta, VDQ Holdings S.A., enquanto os demais acordos foram celebrados no âmbito das participações diretas, detidas na própria companhia, contendo disposições referentes à realização de reuniões prévias.

Nesse contexto, vale destacar que, embora os acordos das companhias Brasil Insurance e Indústrias Romi não apresentem qualquer disposição sobre a eleição de membros da administração, o acordo da companhia Romi apresenta fortes indícios de um acordo de comando. Ainda que apenas um acionista tenha sido classificado como controlador no item 15.2 de seu Formulário de Referência, observou-se que o acordo divulgado pela companhia foi celebrado por sua maior acionista, Fenix Empreendimentos S.A. (controladora e detentora de $37,86 \%$ do capital social), e membros das famílias Romi e Chiti (controladores da Fenix), que, conforme indicado no próprio acordo, são detentores em conjunto de participação correspondente a 43,54\% do capital social total da Romi, tendo sido convencionado no referido acordo que "Os Acionistas Contratantes se comprometem e se obrigam a comparecer em todas as assembleias gerais da Romi, 
exercendo o direito de voto tão somente na forma que tiver sido deliberada na Reunião Prévia." 43

Já no tocante aos acordos de acionistas das 17 companhias remanescentes do Grupo A, observou-se a predominância de disposições referentes ao exercício do poder de controle (obrigatoriedade de realização de reuniões prévias presente em 14 acordos - 50\% do total de companhias integrantes do Grupo A) e à indicação de membros da administração (disposições referentes a indicações ao Conselho de Administração presente em 15 acordos $-53,58 \%$ do total de companhias do Grupo A). Houve, também, bastante representatividade de cláusulas relativas à vinculação de membros da administração ao disposto no acordo de acionistas (11 acordos - 39,29\% do total de companhias do Grupo A) e restrições na transferência de ações (direito de preferência presente em 10 acordos e lock-up em 9 acordos - 32,14\% do total de companhias do Grupo A).

Seguindo em busca de maiores indícios que garantam a identificação de acionistas controladores em companhias sem controle majoritário, constatou-se que, dos 20 acordos de acionistas celebrados no âmbito das companhias do Grupo A, 11 (55\%) apresentaram todas as disposições comumente identificadas em um ambiente de controle compartilhado, conforme prática societária, a saber: (i) cláusulas que disciplinam sobre a realização de reuniões prévias para o exercício do direito de voto e condução das atividades sociais; (ii) cláusulas referentes à indicação de membros para compor o Conselho de Administração; e (iii) cláusulas referentes à vinculação dos administradores ao disposto no acordo em questão.

No entanto, a fim de evitar a contaminação dos resultados apurados, apenas 10 companhias $(35,71 \%$ do total do Grupo A, $16,67 \%$ das companhias sem controle majoritário, e 7,75\% das companhias listadas no Novo Mercado) devem ser consideradas para os efeitos da análise acima, posto que somente nelas os acordos que versam sobre forte influência controladora foram celebrados por acionistas controladores diretos, tendo sido identificada, na maioria das vezes, a própria companhia emissora como parte interveniente: Alliansce Shopping Centers S.A.; ALL América Latina Logística S.A.; Brasil Brokers Participações S.A.; Brookfield Incorporações S.A.; Companhia de

\footnotetext{
${ }^{43}$ Conforme organograma apresentado no item 8 do Formulário de Referência da companhia, divulgado em 29 de maio de 2013, 47,42\% do capital social total estava concentrado nas mãos do grupo controlador: Fenix Empreendimentos S.A.; membros das famílias Romi e Chiti, e Fundação Romi, sendo importante destacar que a companhia não classificou os demais signatários do acordo de acionistas integrantes das famílias Romi e Chiti como acionistas controladores.
} 
Locação das Américas; Cyrela Brazil Realty S.A. Empreendimentos e Participações; Iochpe Maxion S.A.; Magnesita Refratários S.A.; Rossi Residencial S.A.; e T4F Empreendimento S.A. Desconsiderou-se, portanto, o acordo de acionistas divulgado pela Minerva S.A., que, conforme exposto anteriormente, foi celebrado apenas entre acionistas indiretos da companhia.

Em relação às participações detidas pelos cinco maiores acionistas de cada uma das companhias indicadas acima, conforme dados apresentados na Tabela 2 (Apêndice B), verificou-se que todos os acionistas classificados como controladores, nos termos dos itens 15.1 e 15.2 dos respectivos Formulários de Referência, também são indicados como signatários de acordo de acionistas, o que leva a concluir pela existência clara de um bloco controlador em todas as companhias indicadas acima ${ }^{44}$.

Ainda sobre os acordos celebrados para o exercício do controle não majoritário de forma compartilhada, vale mencionar que, em sua maioria, as companhias reconhecem expressamente o objetivo de convenção sobre o exercício do poder de controle, sendo feita, inclusive, referência aos signatários do acordo como acionistas controladores. Também se destaca a preocupação dos signatários com a vinculação dos acionistas às deliberações aprovadas em reuniões prévias, de modo a garantir a manutenção das respectivas deliberações quando da votação das matérias submetidas à assembleia geral ou reuniões do Conselho de Administração.

Outro ponto de forte presença nos dez acordos acima analisados é o cuidado despendido pelos signatários no que se refere à eleição dos membros que comporão a administração da companhia. Expressões relacionadas ao empenho a ser dedicado para a eleição do "maior número de membros possível” são comumente identificadas, merecendo destaque as disposições apresentadas quando da divulgação dos principais termos do acordo de acionistas da Magnesita Refratários S.A.:

O Conselho de Administração da Companhia é composto por 8 membros e igual
número de suplentes, sendo 2 conselheiros independentes. Nos termos do
Acordo de Acionistas Controladores, a eleição dos membros do Conselho é feita
da seguinte forma: (i) Se o número de votos dos Acionistas Controladores for
suficiente para permitir a eleição, pelos Acionistas Controladores, de seis
membros do Conselho de Administração, quatro membros serão nomeados pelo
maior bloco e cada um dos demais blocos nomeará um membro do Conselho de

44 A análise inversa demonstra resultado similar. Ao considerar os cinco maiores acionistas de cada companhia, verifica-se que todos são classificados como controladores, exceto por um único acionista da Rossi Residencial S.A., detentor de apenas 6,57\% do capital social (para mais detalhes, ver Tabela 2, Apêndice B). 


\begin{abstract}
Administração. (ii) Se o número de votos dos Acionistas Controladores for suficiente para permitir a eleição, pelos Acionistas Controladores, de apenas cinco membros do Conselho de Administração, três membros serão nomeados pelo maior bloco e cada um dos demais blocos nomeará um membro do Conselho de Administração. [...] Se o número de votos dos Acionistas Controladores for suficiente para permitir a eleição, pelos Acionistas Controladores, de apenas dois membros do Conselho de Administração, o maior bloco deverá nomear um membro e os demais blocos deverão nomear, em conjunto, um membro do Conselho de Administração. [...] Os Acionistas Controladores renunciaram ao direito de requerer a adoção do procedimento de voto múltiplo. Os Acionistas Controladores sempre elegerão o maior número possível de membros do Conselho de Administração da Companhia conforme o procedimento acima descrito, incluindo na hipótese de o procedimento do voto múltiplo vir a ser adotado e qualquer outro acionista vir a ter e efetivamente eleger um ou mais membros do Conselho de Administração da Companhia. Os Acionistas Controladores não deverão utilizar qualquer direito de eleição em separado ou qualquer direito de eleição de qualquer membro do Conselho de Administração que contrarie o Acordo de Acionistas Controladores. ${ }^{45}$
\end{abstract}

Arranjos como o apresentado acima colocam novamente em pauta a diferenciação entre acordos de defesa e de comando. Embora ambos tenham por objetivo principal a composição dos signatários para o exercício do direito de voto em bloco, resta óbvio que a caracterização do acordo de comando não se pode dar apenas em ambiente no qual os signatários do acordo, necessariamente, componham a maioria do capital social votante. Se assim fosse, os acordos analisados acima seriam classificados erroneamente como de defesa, independentemente do propósito de comando claramente presente.

Nota-se que diversos elementos devem ser igualmente ponderados quando da análise da estrutura acionária de uma companhia e verificação das finalidades de seu acordo de acionistas. Além da simples verificação de existência de um bloco majoritário formado pelos acionistas signatários de acordo, recomenda-se que a composição do bloco formado seja analisada, inclusive, sob a ótica da formação ou não de bloco detentor do poder de controle, nos termos previstos no artigo 116 da Lei das S.A., independentemente de tais acionistas signatários deterem, em conjunto, participação não majoritária sobre o capital social votante.

A análise detalhada de acordos, como os apresentados acima, impede considerar o critério de participação compartilhada majoritária como excludente de acordos que versem sobre o exercício e a manutenção do poder de controle. Seria um erro entender que esses acordos versam apenas sobre a simples defesa de seus signatários contra a arbitrariedade de acionistas majoritários por não haver formação de um bloco detentor da maioria do

${ }^{45}$ Redação conforme informações divulgadas pela companhia Magnesita Refratários S.A., no item 15.5 de seu Formulário de Referência, em 29 de maio de 2013. Disponível em: <http://www.cvm.gov.br>. Acesso em: 20 ago. 2013. 
capital votante, até porque, como visto na pesquisa apresentada no Subtítulo 3.3.1, não foi identificada posição acionária consolidada que seja superior àquela detida pelos acionistas signatários dos acordos analisados.

Logo, não há uma ameaça efetiva ao exercício dos direitos sociais dos acionistas signatários de tais acordos, posto que estes restam por ser titulares das participações mais expressivas no capital social, de tal sorte que havendo o propósito de formação/manutenção de bloco organizador e condutor das atividades sociais, por meio da celebração de acordo de comando, os signatários de tal acordo deveriam ser classificados como acionistas controladores para fins do disposto no artigo 116 da Lei das S.A.

Os resultados obtidos nesta etapa da pesquisa, bem como aqueles apresentados no Capítulo 3.2, reforçam a presença de indícios que corroboram a existência de controle minoritário em companhias listadas no Novo Mercado.

Importante pesquisa realizada por Gorga (2008), quando da análise de amostra composta por 84 companhias listadas nos três segmentos especiais de listagem da BM\&FBOVESPA e sem controle majoritário, demonstrou que 42 companhias (50\%) possuíam acordos de acionistas, dos quais 32 (76,29\%) regulavam sobre o exercício do poder de controle, conforme informações divulgadas nos IANs divulgados com relação aos dados de 2007.

Na mesma linha, estudo mais recente, elaborado pela referida autora em conjunto com Gelman ${ }^{46}$ (2012 apud GORGA, 2013, p. 196-197) demonstrou que, dentre as 107 companhias listadas nos mesmos segmentos e sem acionista controlador majoritário, 55 $(51,4 \%)$ possuíam acordos de acionistas, dos quais $34(58,62 \%)$ regulavam sobre o exercício do poder de controle.

O reconhecimento da possibilidade de exercício do poder de controle por meio da celebração de acordos por acionistas não detentores da maioria do capital votante representa uma ruptura da clássica estrutura de acordos usualmente celebrados por minorias acionárias, em defesa às arbitrariedades dos acionistas controladores majoritários. Os acordos atuais são negociados e estruturados para, entre outros, uniformizar engenhosamente o exercício do controle interno exercido de forma compartilhada, por dois ou mais acionistas.

\footnotetext{
${ }^{46}$ GELMAN, Marina; GORGA, Érica. A evolução da vinculação de conselheiros a acordos de acionistas no Brasil (2007 a 2012). DireitoGV Working Paper, 2012.
} 
Os resultados apurados na presente pesquisa demonstram a utilização de acordos de acionistas como meio de formação e manutenção do poder de controle em um ambiente de alta complexidade societária que surge em decorrência do aumento do grau de dispersão acionária das companhias abertas brasileiras, acompanhado da profissionalização dos operadores do mercado e do direito no Brasil.

Conforme brilhantemente concluído por Gorga (2013, p. 195):

\footnotetext{
Um das consequências mais importantes da recente desconcentração das estruturas de propriedade do capital das companhias abertas brasileiras se refere ao incremento do papel dos acordos de acionistas, que passam a ser claramente utilizados como mecanismos de substituição da propriedade majoritária de ações, na medida em que possibilitam a reconcentração do poder de controle, agora compartilhado entre grupos de acionistas através de convenções contratuais.
}

A constatação da possibilidade de existência de acionistas detentores do poder de controle em companhias sem controle majoritário demanda o estabelecimento de critérios objetivos que permitam a identificação do acionista controlador, com a segurança jurídica necessária para a aplicação das consequências de tal classificação (assunção dos deveres e responsabilidades atribuídos ao acionista controlador na Lei das S.A.).

Nesse contexto, a etapa final da pesquisa realizada na elaboração desta dissertação de mestrado, apresentada a seguir, procederá à análise dos estatutos sociais das companhias com controle não majoritário nas quais foi constatada a existência de acordos de acionistas, com o objetivo exclusivo de verificar a presença de cláusulas de proteção à dispersão acionária e análise de seus principais termos. Pretende-se, assim, apontar outros indícios que colaborem para a identificação de acionista controlador minoritário.

Para mais detalhes sobre os resultados apresentados neste Subtítulo 3.3.2, vide Tabelas 3 e 3.1 (Apêndice C).

\subsubsection{Poison Pills - Principais Estruturas Adotadas}

Dentre os mecanismos utilizados para a manutenção do poder de controle, pode-se mencionar, além da celebração de acordos de acionistas, a utilização de estruturas piramidais, bem como a criação de ações com direitos de voto distintos (MUNHOZ, 2009, p. 139), que permite aos acionistas a manutenção do controle da sociedade, ainda que por 
meio de uma participação acionária minoritária. Da mesma forma, as chamadas poison pills (pílulas de veneno), na forma adotada pelas companhias abertas brasileiras, também devem ser interpretadas como mecanismos utilizados pelos acionistas detentores de maior participação em tais companhias para a manutenção da titularidade do poder de controle sobre a companhia investida.

As poison pills ficaram famosas no Direito norte-americano ao servirem, entre outras modalidades, como mecanismo de proteção às aquisições hostis de controle, conduzidas sem o apoio da administração da companhia alvo (hostile takeovers).

Embora sujeito a críticas pelos aplicadores do Direito norte-americano, o instituto da poison pill traz inúmeros benefícios para a companhia que o $\operatorname{adota}^{47}$. Em um ambiente de alta dispersão acionária, a utilização desse dispositivo, em regra, força o eventual adquirente do poder de controle a negociar a transação diretamente com a administração da companhia, conferindo tratamento igualitário aos seus acionistas, para que estes, entre outros benefícios, sejam preservados do conhecido "dilema do prisioneiro" e não precisem atuar isoladamente diante de eventual tomada de controle ${ }^{48}$.

No entanto, a reflexão que surge para enriquecer o presente estudo está atrelada à adoção desse mecanismo jurídico pela prática societária brasileira. Em linha com a estrutura originalmente identificada na experiência norte-americana, as poison pills surgiram no Brasil diante da forte tendência à dispersão acionária vivenciada ao longo dos últimos anos, de modo que passaram a ser adotadas com maior frequência pela prática societária no período compreendido entre os anos de 2005 e 2008, quando grande parte das companhias brasileiras passou a inserir em seus estatutos sociais disposições relacionadas à

\footnotetext{
${ }^{47}$ Nesse contexto, vale mencionar o interessante estudo elaborado por André Jánszky, sócio do escritório de advocacia norte-americano Shearman \& Sterling LLP, no qual são avaliadas as principais poison pills adotadas na prática norte-americana, sendo ponderadas as consequências práticas de sua adoção sob a ótica de julgados/casos passados (case law): A poison pill norte-americana e sua adoção em outros países. Seminário Instituto Brasileiro de Governança Corporativa (IBGC), realizado em 17 de novembro de 2008, na sede da BM\&FBOVESPA. Material de apresentação disponível em: <http://www.ibgc.org.br>. Acesso em: 11 nov. 2013.

${ }^{48}$ Conforme apontado por Borges et al. (2011, p. 231-232), a teoria dos jogos nos leva a concluir que é muito mais vantajoso ao acionista agir em conjunto diante de uma oferta pela aquisição do controle de determinada companhia, ao invés de agir individualmente. Agindo isoladamente, o acionista se expõe a determinados riscos, como: (i) não alienar sua participação na primeira etapa do processo e restar compelido a efetivar tal alienação em segundo momento, mas em piores condições (second-tier price); (ii) não alienar sua participação, permanecendo na companhia com participação minoritária de baixa liquidez; ou, ainda, (iii) ter sua participação altamente diluída ou ter o preço por ação inicialmente ofertado mais desvalorizado em operação societária subsequente envolvendo, por exemplo, a incorporação ou fusão da companhia (freeze out/squeeze out).
} 
proteção da dispersão acionária, no âmbito da implementação de uma oferta pública inicial de ações (IPO).

Inúmeros são os debates sobre a adoção desse mecanismo de proteção à dispersão acionária pelas companhias abertas brasileiras e suas consequências nas esferas prática e regulatória, descabendo aqui uma abordagem extensiva sobre o assunto. Para fins deste estudo, o tema é direcionado ao propósito dos acionistas quando da adoção desse mecanismo durante período de elevado aquecimento nas operações de IPO no Brasil.

Ocorre que a incorporação do instituto das poison pills pelo Direito brasileiro, resultou na desnaturalização desse mecanismo, que foi empregado nas companhias abertas brasileiras com objetivo diverso do originalmente adotado pelas companhias norteamericanas. Enquanto estas faziam uso do instituto da poison pill com o intento de proteger acionistas não controladores e conferir maior estabilidade à administração da companhia, as companhias brasileiras incorporaram, de fato, o instituto das pílulas de veneno como mecanismo de manutenção do controle societário e não de proteção à dispersão acionária, tal como em sua forma original.

$\mathrm{Na}$ estrutura comumente adotada pelas companhias brasileiras, são inseridas disposições no estatuto social, por meio das quais qualquer acionista (novo ou atual) que atinja/adquira um percentual pré-fixado de ações de emissão de determinada companhia restará obrigado a realizar uma oferta pública de aquisição de ações (OPA), destinada a todos os demais acionistas da companhia para a aquisição da totalidade das ações remanescentes; sendo estabelecidos, ainda, com o objetivo primordial de desestimular o eventual ofertante, critérios de precificação da OPA, que, ao determinarem elevado prêmio sobre o valor de mercado das ações objeto da oferta, resultam em valor extremamente custoso ao então adquirente.

Adicionalmente, a fim de conferir a força necessária para a imposição da obrigação de realizar a OPA, são inseridas no estatuto social disposições que estabelecem a possibilidade de suspensão dos direitos do acionista que não observar a obrigação imposta, sem prejuízo de responsabilidade por perdas e danos causados aos demais acionistas, sendo comum, ainda, a inclusão de redação que veda a alteração do estatuto social para a exclusão das disposições referentes à pílula (“cláusulas pétreas”).

Ora, em um ambiente de alta dispersão acionária, estruturas como as descritas acima, ao tornarem a possibilidade de tomada do controle mais onerosa, teriam, em 
princípio, o objetivo de dificultar tanto a alienação do poder de controle, diante de uma aquisição hostil, como a aquisição do referido poder, por meio de movimentos de escalada via bolsa de valores. No entanto, embora a obrigatoriedade de realização de oferta pelo adquirente de participação relevante crie o ônus necessário para inviabilizar a operação, em linha com a proposta de proteção adotada pelo sistema norte-americano, o propósito de inclusão desses dispositivos nos estatutos sociais das companhias brasileiras restou completamente enviesado.

A lógica do mecanismo de proteção à dispersão acionária, tal como identificada no sistema norte-americano, foi inserida em companhias brasileiras de forma totalmente inversa. Na prática, a obrigatoriedade de realização da OPA para aquisição de ações, mediante pagamento de elevado prêmio pelo adquirente de participação relevante, como estabelecida nas pílulas de veneno brasileiras, inviabiliza a potencial aquisição de controle de qualquer companhia, sendo, na maioria dos casos, perpetuada a posição dos antigos controladores como acionistas detentores de maior participação conjunta na companhia, após o processo de IPO.

Referida dificuldade pôde ser comprovada a partir do ano de 2008, quando, em reflexo à crise econômica mundial que se alastrava na Europa e nos Estados Unidos, durante o mesmo ano, diversas operações de fusões e aquisições foram prejudicadas em decorrência da onerosidade criada por tais cláusulas. Nessa conjuntura, diante da dificuldade encontrada, ainda, para a aprovação de exclusão das disposições referentes à pílula de veneno dos estatutos sociais das companhias-alvo, diversos estudos e questionamentos sobre a eficiência econômica das pílulas de veneno foram elaborados no Brasil, o que resultou na edição do Parecer de Orientação CVM 36, de 23 de junho de 2009, por meio do qual, ao tratar sobre o ônus imposto a acionistas que votassem favoravelmente à supressão de cláusula de proteção à dispersão acionária, a autarquia destacou a incompatibilidade da aplicação desses dispositivos com o disposto nos artigos 115, 121, 122, I, e 129 da Lei das S.A., e manifestou posicionamento sobre a não aplicação de "penalidades, em processos administrativos sancionadores, aos acionistas que, nos termos da legislação em vigor, votarem pela supressão ou alteração da cláusula de proteção à dispersão acionária, ainda que não realizem a oferta pública prevista na disposição acessória.". 49

\footnotetext{
${ }^{49}$ Nesse sentido, vide memorando sobre poison pills elaborado pelos então diretores da CVM, Marcos
} Barbosa Pinto e Otávio Yazbek, ao colegiado da CVM em 14 de abril de 2008 (disponível em: 
É exatamente no contexto das pílulas de veneno brasileiras (as chamadas poison pills tropicalizadas) em que se desenvolverá a última etapa da pesquisa empírica apresentada neste Capítulo 3.

Em busca de elementos que favoreçam a confirmação de existência do controle societário interno não majoritário e que facilitem a sua identificação pelo operador do direito, o último estágio da pesquisa realizada tem por objetivo apurar a existência de previsões estatutárias que disciplinassem sobre as poison pills brasileiras nos estatutos sociais das companhias listadas no Novo Mercado que tivessem: (i) estrutura de capital dispersa e acionista (ou grupo de acionistas) detentor do controle não majoritário, ou seja, aquelas classificadas no Grupo A das companhias sem controle majoritário, conforme identificadas no Capítulo 3.2; e (ii) acordos de acionistas celebrados por detentores de participações de maior relevância acionária, tal como apurado anteriormente.

Para tanto, com base em amostra de 20 companhias listadas no Novo Mercado, integrantes do Grupo A (com controle não majoritário), e com acordos de acionistas declarados à CVM, foram analisadas todas as últimas versões dos estatutos sociais divulgados por essas companhias à CVM, nos termos do disposto no artigo 30, inciso xii, da ICVM $480^{50}$, tendo sido considerado como data de corte o dia 31 de maio de 2013, em linha com o período utilizado para apuração das demais informações objeto de análise para fins da pesquisa apresentada neste Capítulo 3.

$\mathrm{Na}$ análise dos referidos estatutos sociais, além da simples identificação de dispositivos de proteção à dispersão acionária, foram apurados os seguintes elementos sobre o seu mecanismo, conforme consolidados na Tabela 5 (Apêndice E): (i) percentual de disparo da obrigação de realizar OPA (“gatilho”); (ii) estabelecimento de preço mínimo a ser adotado no lançamento da oferta; (iii) exceção de aplicabilidade da regra da OPA para acionistas que detinham participação na companhia, antes da obtenção do registro junto à CVM; (iv) penalidades cabíveis na hipótese de descumprimento da obrigação de realização da OPA; (v) possibilidade de dispensa da OPA, mediante deliberação da

$<$ http://www.cvm.gov.br/port/infos/6491-0.asp>, acesso em: 20 nov. 2013); e Carta Diretriz do IBGC 2, divulgada em 2009, na qual o instituto se posiciona sobre os respeito dos mecanismos de defesa à tomada de controle sob a ótica das boas práticas de governança corporativa (disponível em: $<$ http://www.ibgc.org.br/userfiles/files/Carta_2.pdf>, acesso em: 20 nov. 2013).

${ }^{50}$ Nos termos do referido dispositivo (Art. 30, inciso xiii, da ICVM 480): "O emissor registrado na categoria A deve enviar à CVM, por meio de sistema eletrônico disponível na página da CVM na rede mundial de computadores, [...] estatuto social consolidado, em até 7 (sete) dias úteis contados da data da assembleia que deliberou a alteração de estatuto.". 
assembleia geral e/ou de reunião do Conselho de Administração; (vi) previsão de cláusula pétrea; e (vii) fixação de penalidades para a exclusão da poison pill do estatuto social.

Para fins comparativos, foram inseridos na referida tabela os percentuais de participação detidos pelo maior acionista e pelo grupo de acionistas identificados como controladores em cada companhia analisada para fins deste subtítulo, conforme dados apresentados nas colunas Total de Ações e Total Controle da Tabela 2 (Apêndice B), na qual foram consolidados os dados apresentados no Capítulo 3.2.

Da análise dos estatutos sociais das 20 companhias selecionadas, verificou-se que 15 companhias adotaram a estrutura das pílulas de veneno tropicalizadas $(75 \%$ das companhias objeto de análise e 53,57\% das companhias listadas no Novo Mercado e com controle não majoritário), não tendo sido encontradas disposições nos estatutos das companhias Brookfield Incorporações S.A.; Cyrela Brazil Realty S.A. Empreendimentos e Participações; Hypermarcas S.A.; Magnesita Refratários S.A.; e Marfrig Alimentos S.A.

Em todos os 15 mecanismos de proteção analisados, o método de cálculo do preço por ação de emissão da companhia-alvo, a ser pago no âmbito da OPA, é previamente estabelecido no estatuto social. Em geral, determina-se que o preço de aquisição não poderá ser inferior ao maior valor apurado com base nos seguintes critérios comumente identificados: (i) X\% da cotação unitária média ou mais alta das ações de emissão da companhia, atingida durante determinado período anterior à realização da OPA; (ii) X\% do preço mais alto pago pelo adquirente por ação de emissão da companhia, durante determinado período anterior à realização da OPA; e (iii) o valor econômico da ação de emissão da companhia, conforme apurado em laudo de avaliação.

Todos os mecanismos adotados preveem a possibilidade de perda de direitos pelo acionista que descumprir a obrigatoriedade de realização da OPA, mediante deliberação tomada em assembleia geral convocada para este fim, sendo prevista, ainda, em 11 das estruturas analisadas, a possibilidade de responsabilização desse acionista por perdas e danos causados aos demais.

Quanto à adoção das polêmicas "cláusulas pétreas", observou-se que, dentre as 15 estruturas objeto de análise, apenas 3 (20\%) apresentaram vedações à exclusão desses dispositivos do estatuto social (BHG S.A. - Brazil Hospitality Group; Indústrias Romi S.A.; e Iochpe Maxion S.A.), sendo imposto, nos três casos, a obrigatoriedade de realização da OPA prevista, pelo(s) acionista(s) que tiver(em) votado favoravelmente à 
alteração ou exclusão da respectiva cláusula do estatuto social da companhia, se qualquer previsão de possibilidade de alteração/exclusão da cláusula mediante deliberação do Conselho de Administração e/ou da assembleia geral.

Nos demais casos analisados, a orientação dada pela CVM, por meio do citado Parecer de Orientação n⿳⺈ 36/2009, parece ter sido incorporada aos respectivos estatutos sociais. Das 12 cláusulas remanescentes, 9 possuem previsão expressa sobre a possibilidade de alteração ou exclusão da pílula mediante deliberação do Conselho de Administração e/ou da assembleia geral, enquanto, para os demais casos, a mesma regra deve ser aplicada, posto que a ausência de restrição expressa evidencia a aceitação e compatibilidade do estatuto social em questão com o disposto nos artigos 115, 121, e 122, I, da Lei das S.A.

Nesse contexto, vale citar semelhante estudo realizado por Borges et al. (2011, p. 238-239), no qual, mediante levantamento de informações sobre as 119 companhias listadas no Novo Mercado até 24 de maio de 2011, com o propósito de "verificar empiricamente a existência de uma 'poison pill brasileira', cuja funcionalidade resulte distinta daquela originalmente criada para proteção aos acionistas minoritários e à dispersão acionária", foram identificadas 63 companhias (52,94\%) que continham pílulas de veneno em seus estatutos sociais, das quais 22 apresentaram o mecanismo da "cláusula pétrea".

Sem prejuízo da análise acima, o referido estudo apresentou, ainda, correlação de maior relevância e contribuição para a presente dissertação: a comparação entre o percentual de gatilho da poison pill com o percentual de participação detido pelo acionista (ou grupo de acionistas) detentor do poder de controle. Da análise das referidas 119 companhias, verificou-se que em 45 companhias (aproximadamente 71,43\%) a participação detida pelo controlador era superior ao percentual atribuído como participação relevante (gatilho) (BORGES et al., 2011, p. 239).

A análise do gatilho para disparo da obrigatoriedade de realização da OPA, nas companhias objeto de estudo no presente subtítulo, revelou os seguintes percentuais de participação: (i) igual ou superior a 15\% (Indústrias Romi S.A., Iochpe Maxion S.A. e Rossi Residencial S.A.); (ii) igual ou superior a 20\% (Brasil Brokers Participações S.A., JBS S.A., Mills Estrutura e Serviços de Engenharia S.A., Minerva S.A., Raia Drogasil S.A. e T4F Entretenimento S.A.); (iii) superior a 20\% (ALL América Latina Logística S.A.); (iv) igual ou superior a 25\% (Companhia de Locação das Américas e Linx S.A.); (v) igual 
ou superior a 30\% (Aliansce Shopping Centers S.A.); e (vi) igual ou superior a 35\% (BHG S.A. - Brazil Hospitality Group).

Os percentuais acima, que resultam em um gatilho correspondente à participação média de $21,33 \%$ do capital social, evidenciam a clara proteção à dispersão acionária contra qualquer movimento de consolidação das participações acionárias na companhia que faz uso desse dispositivo. No entanto, a confirmação do propósito exclusivo de proteção à dispersão acionária deve ser dada mediante análise dos percentuais de gatilho em conjunto com as informações apresentadas nas colunas Total de Ações e Total Controle da Tabela 5 (Apêndice E), cujos dados foram extraídos das informações apresentadas na Tabela 2 (Apêndice B).

Para efeitos práticos, vale citar levantamento apresentado por Munhoz (2010, p. 312-313):

[...] verificou-se que os estatutos estabelecem participações mínimas como suficientes para disparar a OPA, em média, de $10 \%$ a $35 \%$ do capital. Por outro lado, a média geral de participação dos maiores acionistas nas companhias listadas no Novo Mercado é de $36,39 \%$, subindo para $45,25 \%$, se considerado o efeito dos acordos de acionistas, usualmente utilizados com o instrumento de organização do poder de controle.

Nesse contexto, ao examinar a base de dados objeto deste Subtítulo 3.3.3 observouse que em apenas 2 das 15 companhias que possuíam pílulas de veneno em seus estatutos sociais (Brasil Insurance Participações e Administração S.A., e Iochpe Maxion S.A.), as participações acionárias detidas pelo grupo controlador, conforme apuradas no Capítulo 3.2, não eram superiores ao percentual estabelecido como gatilho para a obrigação de realização da OPA; sendo que, dentre as 13 companhias nas quais o percentual de gatilho era inferior à participação de controle, 4 companhias possuíam o maior acionista controlador com participação superior ao percentual de gatilho (ALL América Latina Logística S.A., Indústrias Romi S.A., JBS S.A, e Minerva S.A.). Esses dados comprovam a suspeita de que a efetividade da maioria das pílulas de veneno adotadas pelas companhias listadas no Novo Mercado com controle não majoritário encontrava-se diretamente destinada aos demais acionistas, não integrantes do bloco controlador.

Sob essa ótica, cumpre ressaltar que muitas das pílulas de veneno adotadas pelas companhias brasileiras excetuam a necessidade de realização de oferta com relação às participações relevantes (percentual de gatilho) adquiridas/acumuladas antes da abertura de capital. Ou seja, nessas companhias, o lote de ações que permanece, após o processo de 
IPO, nas mãos do(s) acionista(s) controlador(es), condutor(es) do lançamento da oferta inicial, não é considerado como participação relevante para fins de disparo da obrigação da OPA, restando claro o objetivo desse acionista (ou grupo de acionistas) de intimidar a aquisição de participações relevantes superiores àquelas que remanescerão sob sua titularidade, após a realização do IPO.

Dessa forma, ainda que o processo de IPO resulte em diluição do acionista ou grupo controlador, em grau suficiente para que este deixe de deter participação superior à maioria do capital votante, o referido acionista (ou grupo de acionistas), por meio da utilização da poison pill tropicalizada, permanece na posição de controlador de sua companhia, ainda que mediante exercício do controle não majoritário.

Por meio dos dados apresentados na coluna Exceção para Acionistas Anteriores ao Registro na CM da referida Tabela 5 (Apêndice E), foi possível verificar que 11 das 15 pílulas identificadas possuem em seu mecanismo exceção de obrigatoriedade de realização da OPA para as participações relevantes que sejam detidas e/ou acumuladas antes do registro da companhia junto à CVM, sendo que, dentre as 11 companhias citadas, 9 delas possuem percentual de gatilho inferior ao de participação detido pelo bloco de controle (Alliansce Shopping Centers S.A.; ALL América Latina Logística S.A.; Brasil Brokers Participações S.A.; Companhia de Locação das Américas; Indústrias Romi S.A.; Linx S.A.; Minerva S.A.; Raia Drogasil S.A.; e T4F Empreendimento S.A.). Ou seja, não devem existir dúvidas sobre o fato de que as poison pills adotadas pelas 9 companhias listadas servem de artifício para a manutenção do poder de controle.

Essa constatação está em consonância com entendimento manifestado por Borges et al. (2011, p. 240). Ao analisarem os dados apurados na pesquisa por eles realizada, o autores concluem que o propósito da utilização da pílula de veneno no Brasil diverge dos objetivos da pílula norte-americana, "servindo, na grande maioria das vezes, de reforço do poder de controle, permitindo a um acionista ou grupo de controle manter esse poder sem nem mesmo deter mais do que $50 \%$ (cinquenta por cento) do capital social votante.”.

Ora, em posse de mecanismos de criação de ônus ao acionista adquirente de participação relevante, tal como descritos neste Subtítulo 3.3.3, a existência prática de um acionista com participação superior à detida pelos então controladores não majoritários, torna-se inviável. Essa realidade favorece em completo a perpetuidade do poder de controle nas mãos de acionista (ou grupo de acionistas) detentor de participação inferior à maioria do capital votante, ao proporcionar a tais acionistas ambiente favorável ao 
exercício do poder de controle ainda que mediante titularidade de participação não majoritária.

Nesse contexto, uma vez confirmada a existência do controle minoritário em companhias listadas no Novo Mercado, o desenvolvimento da presente dissertação é direcionado à análise da concepção de acionista controlador, à luz da nova realidade de organização de poder nas companhias listadas no Novo Mercado, tal como apresentada neste Capítulo 3.

Para mais detalhes sobre os resultados apresentados neste Subtítulo 3.3.3, vide Tabela 5 (Apêndice E). 


\section{CAPÍTULO 4 \\ CONCEITO DE CONTROLE MINORITÁRIO}

\subsection{Noções Introdutórias}

Tema central das sociedades por ações, a conceituação do termo controle e das expressões poder de controle e acionista controlador tem sido objeto de constante estudo pela doutrina societária brasileira, em conjunto com a concepção do princípio da soberania da assembleia geral, em especial, após publicação da brilhante obra de Fabio Konder Comparato sobre o poder de controle na sociedade anônima, cuja primeira edição se deu em 1976.

Em que pesem a rica bibliografia disponível sobre o controle societário e a vasta complexidade de diversas questões correlatas, pretende-se apresentar neste capítulo breves considerações introdutórias sobre o tema, com o intuito de proporcionar subsídios suficientes para a colocação do instituto do controle minoritário conforme os entendimentos apresentados pela doutrina e avaliação de sua existência no ordenamento jurídico brasileiro.

Ressalta-se que o objetivo central deste trabalho é a identificação do controle minoritário nas companhias listadas no Novo Mercado. Comprovada a sua existência, por meio da pesquisa empírica apresentada no capítulo anterior, procede-se, neste capítulo quarto, à análise dos reflexos práticos e jurídicos dessa constatação.

Para manifestarem a vontade social, dependem os entes coletivos de organização interna. No âmbito das sociedades por ações, a capacidade de ditar a vontade social possui papel central na definição dos rumos das atividades da companhia. Identifica-se, nesse tipo societário, estrutura hierárquica na qual a assembleia geral de acionistas figura como órgão supremo tido como a última instância da estrutura de gestão, sendo atribuídos à assembleia poderes de decisão sobre questões fundamentais à consecução das atividades sociais.

Exceto pelas matérias, que, por afetarem profundamente a vida social e/ou o relacionamento entre acionistas e companhia, dependem de quórum qualificado para 
aprovação (artigo 136, da Lei das S.A.), as deliberações sociais, em regra geral, encontram-se subordinadas à vontade de acionistas titulares de participação que corresponda à maioria absoluta de votos proferidos pelos acionistas presentes na reunião, não sendo computados os votos em branco, conforme disposto no artigo 129, da Lei das S.A.

Nesse sentido, Guerreiro e Teixeira (1979) defendem que as sociedades por ações seriam governadas pelo princípio do majoritário e esclarecem: soberano na regra e na exceção, o princípio assegura aos titulares de maior quantidade de ações com direito a voto a prevalência nas decisões da assembleia geral, determinando a manifestação da vontade social e vinculando a todos os acionistas, mesmo que ausentes ou dissidentes.

Ressalta-se que os poderes decisórios conferidos em lei à assembleia geral outorgam ao órgão poder de comando sobre o comportamento da companhia, inclusive no que se refere à composição e estrutura de sua administração. Legitimam, portanto, o exercício do controle sobre a condução das atividades sociais. Dessa forma, o poder de controle se identifica, entre outros elementos, por meio do predomínio da vontade de um acionista (ou grupo de acionistas) nas deliberações tomadas em assembleia geral e não, necessariamente, com base no capital social total.

Nesse contexto, esclarece Lucena (2009, p. 1080): "Daí e ao contrário do que a coito se pensa, o conceito de acionista controlador não se confunde com acionista majoritário, este sim exigente da titularidade de ações que ultrapassem a metade do capital votante.".

O nascimento do acionista controlador mediante exercício do direito de voto que forme a maioria na assembleia geral reduz a igualdade atribuída aos acionistas quando da determinação, em lei, de que a cada ação ordinária será atribuído o direito a um voto (artigo 110, da Lei das S.A.), distinguindo qualitativamente as ações às quais são atribuídas o comando da sociedade (capital dirigente) das demais tidas como a minoria do capital social (capital monetário) (GALGANO ${ }^{51}$ apud GUERREIRO; TEIXEIRA, 1979, p. 292).

Sobre a referida distinção, vale citar, novamente, os ensinamentos de Lamy Filho e Bulhões Pedreira (1997, p. 184):

\footnotetext{
${ }^{51}$ GALGANO, Francesco. La Società per Azione. Le Altre Società. Le Corporative. 2. ed. Bologna, 1974. p. 25.
} 
O empresário-empreendedor é fundador ou acionista controlador, e em geral exerce um dos cargos da administração [...]. A função do investidor, graças à divisão do capital em ações, pode ser exercida, simultaneamente, pelo empresário-empreendedor e por milhares ou milhões de investidores do mercado [...]. A história das grandes empresas de capital aberto, em todos os países do mundo ocidental, desenvolveu-se segundo as mesmas etapas. Nasceram da iniciativa de um empresário-empreendedor, com capacidade de liderança e disposição de aceitar riscos, que reuniu fatores de produção, criou a empresa, e a fez crescer [...] até o limite da sua capacidade de aplicar capital. Precisando de mais capital para continuar a expandi-la, passa a aumentar o capital social mediante sucessivas emissões de ações no mercado, mantendo o controle acionário (com porcentagem cada vez menor) devido à dispersão das ações vendidas entre grande número de investidores do mercado, que não desejam nem aceitam qualquer interferência ou responsabilidade na direção da empresa, porque seu objetivo é exercer apenas aparte da função empresarial correspondente à aplicação de capital de risco.

Com a edição da lei acionária de 1976, procurou-se impulsionar o mercado de capitais brasileiro como alternativa de captação pelas companhias brasileiras. No entanto, o referido diploma foi efetivamente elaborado em torno da figura do acionista controlador, respeitando o caráter concentrado e familiar da propriedade acionária das companhias brasileiras. Não é por outra razão que o artigo 116 da Lei das S.A. conferiu status jurídico à figura do acionista controlador, imputando-lhe deveres e responsabilidades (LAMY FILHO, 2007, p. 158).

Tal como ocorre com outras nações em desenvolvimento, há forte resistência à adoção de práticas pró-diluição pelo mercado brasileiro. A estrutura societária brasileira possui longa história de concentração de poder e de gestão familiar. O histórico de condução dos negócios sociais, por meio de estrutura de capital concentrado, encontra-se claramente arraigado às atividades mercantis conduzidas no País. Destaca-se, nesse sentido, entendimento de Salomão Filho (2011, p. 98):

\footnotetext{
O sistema de repartição de poderes levou em conta a realidade extremamente concentrada das sociedades por ações no Brasil. Não tentou criar uma contra tendência, mas sim regulamentar a realidade existente. Com isso sem dúvida aprofundou, nesses 30 anos de vigência da Lei 6.404, a dependência do próprio modelo concentracionista. Pode-se criticar o legislador brasileiro pela falta de idealismo, mas não pela ausência de realismo. $\mathrm{O}$ sistema foi elaborado em torno da figura do acionista controlador, verdadeiro centro decisório da sociedade.
}

No momento em que as captações via mercado de capitais ganham destaque aos olhos dos acionistas controladores, contudo, a estrutura da propriedade acionária concentrada é reavaliada, em face das vantagens e desvantagens da existência de um acionista controlador na companhia. 
Nesse contexto, tal como ressaltado por Dick e Zingales (2003), a extração de benefícios privados do controle ganha destaque central na literatura societária. Enquanto houver benefícios a serem extraídos pelo acionista na posição de comando sobre as atividades sociais, estruturas organizacionais que privilegiam a concentração acionária permanecerão como predominantes entre as companhias brasileiras e a figura do empresário-empreendedor, na maioria dos casos, se sobreporá à figura do simples investidor.

Conforme constatado nos capítulos anteriores, embora seja possível identificar, em reflexo ao fenômeno da dispersão acionária, forte adesão das sociedades por ações à alternativa de captação de recursos via mercado de valores mobiliários, nota-se na prática societária uma clara objeção a medidas que privem completamente o aproveitamento das vantagens obtidas na posição de comando.

Em sua maioria familiares e fundadores das companhias, os então controladores acabam por aceitar adoção de regras de melhores práticas de governança pela companhia e toleram a diluição de suas participações vis a vis os benefícios advindos da abertura do capital e da captação de recursos junto à poupança popular. No entanto, esse movimento parece, em alguns casos, ser dominado por medidas engenhosamente arquitetadas para que a posição de comando seja mantida.

O Brasil vive um momento único, de intensa consolidação econômica, que reflete em novas configurações societárias. Observa-se um cenário divergente em que benefícios passíveis de aproveitamento pelo acionista controlador sobrevivem ao incremento da dispersão da propriedade acionária no Brasil, permitindo-se a caracterização de ambiente propício para o surgimento das companhias com capital relativamente pulverizado, e, consequentemente, da manifestação do poder de controle exercido por acionistas detentores de participação não majoritária. Por esse motivo, merece análise o instituto do controle minoritário.

Conforme já destacado ao longo desta dissertação, vivemos um momento intenso de mudanças que impactam na estrutura da propriedade acionária das companhias brasileiras e refletem em certa diluição dos acionistas controladores. No entanto, deve-se reconhecer que o controle gerencial, tal como materializado nas companhias dos Estados Unidos e Reino Unido, ainda não é predominante entre as companhias sem controle majoritário. 
Sobre o tema, Salomão Filho (2011, p. 78) afirma:

\begin{abstract}
É impossível imaginar em hipóteses normais um controle administrativo em sentido próprio, i.e., em ausência de um controlador ativo. Existem companhias controladas por administradores que também são acionistas (mais próprio seria dizer o inverso, i.e., acionistas que também são administradores). Essa realidade é até mesmo comum. O que praticamente inexiste é o controle administrativo com acionariado diluído.
\end{abstract}

Enquanto de um lado é identificada certa consolidação do mercado de capitais, atrelada à profissionalização dos agentes, ao incremento das operações e da regulamentação aplicável, bem como ao desenvolvimento da economia nacional; de outro, a cultura pela manutenção do controle societário permanece arraigada à noção de investimento de muitos acionistas de companhias brasileiras, manifestando-se o controle minoritário.

A existência de companhias com capital relativamente pulverizado, controladas por bloco não majoritário, é uma realidade das companhias listadas no Novo Mercado, como se comprovou no capítulo anterior.

Nesse sentido, Azevedo (2010, p. 232) reconhece que as companhias abertas, ainda que com alto índice de dispersão acionária, são controladas por acionistas que, apesar de deterem menos da metade do total das ações com direito a voto, possuem, de fato, a prerrogativa de fazer prevalecer sua vontade nas deliberações assembleares e na eleição da administração.

Em termos gerais, entende-se por controle minoritário aquele exercido poder acionista que, embora titular participação não majoritária no capital social votante, faz prevalecer sua vontade sobre a condução dos negócios sociais e elege a maioria dos administradores da companhia investida. Não obstante, como se mostrará a seguir, a doutrina se divide quanto à existência desse instituto no ordenamento jurídico brasileiro, sendo importante a reflexão sobre o instituto do controle minoritário para que o direito societário esteja apto a regular questões decorrentes dessa nova realidade das companhias listadas no Novo Mercado.

Fenômeno recente na realidade das sociedades por ações brasileiras, o instituto do controle minoritário não pode ser desconsiderado. Deve o aplicador do Direito Societário avaliar as consequências desse reconhecimento e ponderar os deveres e responsabilidades que devem ser consequentemente assumidos pelo titular do controle minoritário, uma vez 
que, conforme será demonstrado no capítulo a seguir, a prática societária já enfrenta diversos desafios no âmbito da identificação e efetiva imputação de direitos e deveres ao acionista controlador minoritário.

\subsection{Consequências Práticas}

Conforme restou evidente, pela pesquisa empírica realizada, a existência do instituto do controle minoritário é realidade entre as companhias listadas no segmento especial do Novo Mercado. Embora a doutrina não seja unânime quanto a isso, pode-se depreender, das considerações apresentadas no capítulo anterior, que posição majoritária admite o instituto do controle minoritário e reconhece previsão de sua existência no ordenamento jurídico brasileiro.

No entanto, por se tratar de fenômeno recente, no âmbito das questões que envolvem as sociedades por ações, nota-se, na prática, o surgimento de diversos casos que exigem reflexão por parte dos operadores do Direito Societário sobre as consequências decorrentes da presença de acionista controlador entre companhias de capital aberto, em especial as listadas no Novo Mercado.

Este capítulo descreverá questionamentos recentes envolvendo o instituto do controle minoritário, com o objetivo de ressaltar a importância de sua reflexão. Identificados na prática societária, acredita-se que os temas ora apresentados servem de elemento para verificação da efetiva imputação de deveres e responsabilidades ao acionista controlador, nos termos previstos na Lei das S.A., independentemente do poder de controle ser exercido mediante titularidade de participação acionária correspondente à maioria do capital votante ou por meio de participação não majoritária.

Em termos gerais, as principais discussões práticas sobre o instituto do controle minoritário recaem sobre os requisitos necessários para a caracterização do poder de controle, estabelecidos no artigo 116, da Lei das S.A., em suas alíneas "a" e "b": (i) a preponderância permanente sobre as deliberações sociais; e (ii) o exercício efetivo do poder de controle, em especial sobre a aplicação cumulativa ou independente dos referidos requisitos e permanência e efetividade. 
Destaca-se que a CVM ainda não apresentou manifestação formal e unânime sobre a identificação do controle minoritário em companhias de capital aberto. Da análise de julgados proferidos pela autarquia sobre o tema, observa-se, em uma primeira fase da autarquia, entendimento categórico favorável à cumulação dos requisitos de permanência e exercício efetivo do poder como condição para a configuração do acionista controlador. Por outro lado, no âmbito do clássico, debate sobre a interpretação relativa do artigo 116, para fins da obrigação de realização de oferta pública decorrente da alienação do poder de controle (OPA de tag along), nos termos previstos no artigo 254-A da Lei das S.A., colocando esse posicionamento em xeque.

Como se demonstrará a seguir, a autarquia já havia reconhecido a obrigatoriedade da referida oferta apenas na hipótese de permanência, sendo, dessa forma, dispensada a OPA quando verificada apenas o requisito de exercício efetivo do poder de controle (artigo 116, "b", da Lei das S.A.). No entanto, manifestações recentes sobre casos de maior complexidade, que retomaram as discussões sobre a configuração do controle minoritário, demonstraram a aceitação de membros do colegiado não apenas quanto à sua existência, como, também, ao disparo da obrigatoriedade de realização da oferta quando da aquisição do controle minoritário, consoante referido artigo 254-A da Lei das S.A.

Ao analisar, entre outros, a eventual ocorrência de abuso de poder de controle, na eleição do representante dos acionistas preferencialistas no Conselho Fiscal do Banco Sudameris Brasil S.A., o então diretor relator do Processo Administrativo Sancionador (PAS) CVM TA RJ 2001/9686, Luiz Antonio de Sampaio Campos, sustentou no voto proferido em 12 de agosto de 2004:

\footnotetext{
Enfatize-se que, nos termos da lei, para que se caracterize o acionista controlador, é necessário que o acionista reúna essas condições acima apontadas, cumulativamente, notadamente: (i) que seja titular de direitos de sócio que lhe assegure, de modo permanente, a maioria dos votos nas deliberações da assembléia geral; (ii) detenha o poder de eleger a maioria dos administradores; mas só isso a princípio não basta, a lei exige, ainda, que o acionista controlador use esses direitos para dirigir as atividades sociais. (grifo nosso)
}

Seguindo entendimento de que a configuração do poder de controle dependeria, necessariamente, do preenchimento do requisito de permanência, posição semelhante foi adotada em voto proferido no Processo CVM RJ 2005/4069, em que o colegiado da autarquia analisou, em 11 de abril de 2006, recurso contra decisão da Superintendência de Registro de Valores Mobiliários (SRE) e da Superintendência de Relações com Empresas 
(SEP), que determinaram a realização da OPA de tag along decorrente alienação de controle da Companhia Brasileira de Distribuição (CBD).

Em seu voto, o então diretor relator, Pedro Oliva Marcilio de Souza, sinalizou entendimento sobre a não aplicabilidade da obrigação, quando presente apenas o requisito de exercício efetivo do poder:

Outro ponto importante desse primeiro requisito é a necessidade de permanência do poder. Em razão dele, vencer uma eleição ou preponderar em uma decisão não é suficiente. [...] Por esse motivo, em uma companhia com ampla dispersão, ou que tenha um acionista, titular de mais de $50 \%$ das ações, que seja omisso nas votações e orientações da companhia, aleatório acionista que consiga preponderar sempre, não está sujeito aos deveres e responsabilidades do acionista controlador, uma vez, que preponderá por questões fáticas das assembleias não preenchendo o requisito da alínea 'a' do art. 116 , embora preencha o da alínea ' $b$ '. Esse acionista seria considerado, para determinação de sua responsabilidade, como um acionista normal (sujeito, portanto, ao regime do art. 115). (grifo nosso)

O entendimento acima foi confirmado pelo então diretor da autarquia, Marcelo

Trindade, na ocasião do pronunciamento de seu voto no Processo CVM RJ 2007/7230, muito embora ainda pairassem reflexões sobre a adequação do tema:

A lei também poderia determinar que a aquisição de um percentual menor que $50 \%$ das ações determinasse a realização da OPA, independentemente de quem as alienasse, ou estabelecer um sistema em que o alcance da propriedade de um certo percentual de ações determinasse a realização de OPA. Talvez esses sistemas sejam melhores. Mas esses não são os sistemas da lei brasileira. [...]

Concluir pela não obrigatoriedade de OPA em casos de consolidação do controle dentro do bloco não é, certamente, adotar a decisão mais simpática. E certamente este não é o voto que eu mais gostaria de dar. De lege ferenda, me parece que a alienação de participações relevantes, conforme percentual previsto em lei ou no Estatuto, deveria gerar a obrigação de estender as mesmas condições aos demais acionistas, através da realização de OPA. Isto contribui para que o valor das ações de uma companhia aberta seja estabelecido pelo mercado de maneira mais adequada, sem prêmios ou descontos economicamente pouco justificáveis, decorrentes de direitos não expressos nos títulos, mas sim inerentes ao exercício do poder.

Mas o fato é que, de lege lata, estou de acordo com a conclusão do voto do Diretor Relator, pela inexistência de alienação de controle, que só pode ser alienado por quem o detenha, o que, em casos de acordo de acionistas, significa o grupo de pessoas vinculadas por acordo de voto, como diz o art. 116 da Lei das S.A., e não um membro desse grupo que detenha menos que a maioria das ações com voto, ressalvada a análise do acordo de acionistas, que revele a preponderância do subscritor alienante perante os demais.

Nota-se que, até então, a CVM havia sinalizado posicionamento apenas com relação à aplicabilidade do disposto no artigo 254-A da Lei das S.A., no âmbito do controle 
interno majoritário, mantendo posição de que o referido artigo somente seria aplicável para essa hipótese. Por conseguinte, a autarquia direcionou o entendimento indireto de que a configuração do acionista controlador se daria, para todos os demais propósitos da lei acionária, apenas mediante a identificação de ambos os requisitos previstos no artigo 116 da do referido diploma.

Ocorre que, diante da nova realidade da propriedade acionária no Brasil e do incremento das operações envolvendo valores mobiliários, novos desafios surgem para a CVM, tal como ocorreu no emblemático julgamento de recurso interposto contra decisão da SRE, que determinou a realização da OPA de tag along para aquisição de ações de emissão da Tim Participações S.A., em decorrência da alienação indireta do seu controle (Processo CVM RJ 2007/14344).

Referido recurso foi interposto pela Telco S.p.A., que, após operação societária efetivada na Itália, resultou titular de $25 \%$ do capital social Telecom Itália S.p.A., controladora indireta da Tim Participações S.A. Segundo os acionistas minoritários da Tim (requerentes), o controle de fato da companhia brasileira teria sido alienado para a Telco, que, sob a égide da legislação italiana, seria controladora indireta da companhia, e, portanto, caberia a condução da OPA de tag along, conferindo aos demais acionistas da Tim Participações S.A. os direitos de participação no prêmio de controle, tal como previsto no Regulamento do Novo Mercado.

A discussão desse caso exigiu o posicionamento da autarquia sobre dois temas de alta complexidade e relevância: a aplicabilidade de norma estrangeira para regular a definição de controle, bem como a identificação do controle minoritário em companhias de capital disperso, uma vez que a legislação italiana apresentava critérios mais objetivos para o reconhecimento do acionista minoritário. De tal sorte, os controversos votos proferidos pelos diretores da autarquia, embora todos muito bem fundamentados, demonstraram a clara dificuldade na combinação dos artigos 254-A e 116 da Lei das S.A.

Conforme exemplo de Martes et al. (2012), enquanto o diretor Otávio Yazbek reconheceu a existência do controle minoritário no ordenamento jurídico brasileiro e ressaltou a necessidade de critérios objetivos que conferissem maior segurança para a aplicação do disposto no artigo 254-A da Lei das S.A. às hipóteses de alienação do controle minoritário, o diretor Eli Loria manifestou-se tacitamente contrário ao reconhecimento do controle minoritário para fins da realização da OPA obrigatória. 
Em contraponto, apesar de vencido no mérito, o voto proferido pelo diretor relator Eliseu Martins (acompanhado pelo voto do diretor Marcos Pinto), que concluiu pela exigibilidade da OPA, por ter sido configurada hipótese de alienação do controle minoritário indireto, tornou-se de suma importância, por ser o primeiro precedente em que representantes da CVM se posicionam claramente favoráveis à aplicação do disposto no artigo 254-A da Lei das S.A. em situações de alienação do controle não majoritário (SILVA, 2012).

Em que pesem a relevância do direito de venda conjunta e consequente obrigatoriedade de realização da oferta de tag along, nos termos previstos no artigo 254-A, a qual é merecedora de extenso estudo sobre o tema, destaca-se, no âmbito dos questionamentos apresentados nesta dissertação, a contrariedade apresentada nos votos proferidos acima. Os diferentes fundamentos utilizados e a falta de posicionamento claro sobre o tema ressaltam a necessidade de estudo do instituto do controle minoritário, em busca de elementos que confiram maior segurança às relações societárias e de mercado de capitais.

Ainda sobre a análise de precedentes que evidenciam questões decorrentes da nova realidade da estrutura de propriedade acionária das companhias brasileiras, entende-se por bem citar recente análise conduzida pela CVM, no âmbito do controle interno exercido de forma compartilhada.

Destaca-se o Processo CVM RJ 2011/13706, instaurado pela SRE para apurar eventual incidência de OPA por alienação de controle da Usinas Siderúrgicas de Minas Gerais S.A. (Usiminas), consoante artigo 254-A da Lei das S.A., em decorrência da celebração de contratos de compra e venda de participação na companhia entre sociedades vinculadas ao bloco de controle existente (Grupo V/C, Grupo Nippon e Caixa dos Empregados da Usiminas - CEU), e terceiros que não detinham qualquer participação no capital votante da companhia (Grupo T/T).

Conforme detalhamento dos fatos apresentados pelo gerente de Recursos, Ricardo Maia da Silva, no MEMO/SRE/GER-1/14/2012, de 2 de fevereiro de 2012, por meio da implementação da operação contemplada nos contratos celebrados pelas partes: (i) o Grupo T/T adquiriu a totalidade das ações detidas pelo Grupo V/C e passou a fazer parte do bloco de controle da Usiminas, com 27,66\% das ações ordinárias de emissão da companhia e 43,31\% do total de ações vinculadas ao novo acordo de acionistas decorrente dessa operação; (ii) o Grupo Nippon, antes detentor de 27,76\% das ações ordinárias da Usiminas e $43,47 \%$ das ações vinculadas ao acordo original, passou a deter $29,45 \%$ das ações 
ordinárias e 46,12\% do total de ações vinculadas ao novo acordo de acionistas, celebrado quando da implementação da operação; e (iii) a Caixa dos Empregados da Usiminas (CEU), que alienou parte de suas ações na Usiminas ao Grupo Nippon e ao Grupo T/T, permaneceu no bloco de controle e signatária do novo acordo, mas com participação reduzida de $10,13 \%$ para $6,75 \%$.

Em sua defesa, a Usiminas alegou não ser aplicável a obrigatoriedade da OPA por alienação de seu controle acionário, uma vez que a operação societária realizada não resultou na efetiva transferência de seu controle, mediante substituição de antigo controlador por um novo membro ingressante no bloco de controle, que assumisse posição de comando sobre as atividades sociais.

O que se notou na prática foi a manutenção do percentual de $63,86 \%$ do capital social da Usiminas, sob titularidade do bloco de controle, que permaneceu sendo composto por maior participação detida pelo Grupo Nippon. Inclusive, conforme divulgado em fato relevante de 17 de janeiro de 2012, o novo acordo de acionistas firmado pelos membros do "novo" bloco substituiu e revogou o acordo original, porém, manteve em sua essência os mesmos mecanismos e princípios de governança.

Dessa forma, pelos fatos acima expostos, a autarquia reconheceu como requisito fundamental para a existência de novo acionista controlador a necessidade de efetiva mudança na titularidade do poder de controle, concluindo pela não aplicabilidade da OPA por alienação de controle de Usiminas, uma vez que a operação, como um todo, não resultou na formação de um novo bloco controlador, tendo sido mantido o antigo controlador no exercício do poder de controle sobre a Usiminas.

Não obstante, ainda que o bloco de controle tenha sido mantido em seu formato original e que a maior participação tenha permanecido sob domínio do Grupo Nippon, sujeito às mesmas regras e mecânicas utilizadas para o acordo de acionistas anterior, a ínfima diferença entre os percentuais de participação detidos pelos Grupos Nippon e T/T $(0,16 \%$ do total das ações vinculadas ao novo acordo $)$ traz à baila questionamento sobre a necessidade de adoção de critérios mais objetivos, que permitam a clara confirmação de presença de acionista controlador não majoritário em determinada companhia.

Ora, se ambos os grupos fossem titulares da mesma participação, as ações adquiridas pelo grupo ingressante não deveriam ser consideradas como participação estratégica e fundamental para o exercício do poder de controle sobre a Usiminas? 
Sobre o exercício do poder de controle mediante posição estratégia na companhia, sustenta Herman (1981, p. 27):

\begin{abstract}
Ownership has been and remains an important basis for obtaining strategic position; it has a solidity as a power base beyond that available to the promoter and banker, assuming retention of a large proportionate interest. Stock-based power and strategic position reinforce each other. But with the rapid growth in corporate size, the sales of new issues in the public Market, and the divestment of stock by the former dominant owners, the retention for control by the former owner group will depend increasingly on the power derived from strategic position - occupational role and status - rather than ownership.
\end{abstract}

Observa-se, nos dias atuais, o surgimento de minorias controladoras, que, por adotarem, muitas das vezes, posição de investimento estratégico na companhia, acabam por atuar de forma presente junto à administração da companhia, determinando claramente a forma de condução das atividades sociais, independentemente da participação detida no capital social.

A exemplo, destaca-se participação acionária detida pela gestora de recursos Tarpon Investimentos S.A. (Tarpon) na Brasil Foods S.A. (BRF), ambas companhias abertas listadas no Novo Mercado. Conforme dados divulgados pela BM\&FBOVESPA, ao mercado, em 20 de fevereiro de 2014, a Tarpon detinha 8,02\% do capital social total da $\mathrm{BRF}^{52}$, figurando como terceira maior acionista, sendo as maiores posições acionárias detidas por Previ - Caixa Previdência Funcionários Banco do Brasil (12,20\%) e Petros Fundação Petrobras de Seguridade Social (12,10\%), respectivamente.

A partir dos dados apresentados pela BRF em seu Formulário de Referência de 2013, a Tarpon, que à época já era acionista da companhia, não figurava como controladora na composição de seu capital social, posto que a BRF não possui qualquer acionista controlador (linha 20, Tabela 2 - Apêndice B), sendo classificada, com base nesse critério, como companhia de capital pulverizado.

No entanto, como de conhecimento geral, diversos movimentos ativistas por parte da gestora Tarpon levam ao questionamento sobre a zona cinzenta que delimita as posições de acionista ativista detentor de participação minoritária e acionista detentor de participação controladora minoritária. Seja na qualidade de um ou de outro, o poder de influência da gestora na condução das atividades da BRF restou evidente durante o ano de 2013.

Conforme amplamente divulgado na mídia, a Assembleia Geral Ordinária da BRF,

\footnotetext{
${ }^{52}$ Disponível em: < http://www.bmfbovespa.com.br/Cias-Listadas/Empresas-

Listadas/ResumoEmpresaPrincipal.aspx?codigoCvm=16292\&idioma=pt-br >. Acesso em: 20 fev. 2014.
} 
realizada em 9 de abril de 2013 e instalada com a presença de 81,18\% do capital votante, elegeu, para compor o Conselho de Administração da companhia, entre outros, o Sr. Abílio dos Santos Diniz, como presidente, e os acionistas controladores da gestora, Srs. Pedro de Andrade Faria e Fernando Shayer, como membro independente e respectivo suplente. Sete meses depois, em reunião do Conselho de Administração, realizada em de 14 de novembro de 2013, Pedro Faria é eleito diretor presidente internacional (CEO Internacional), com as devidas abstenções de Pedro de Andrade Faria e Fernando Shayer.

No mesmo contexto, cita-se a repercussão no mercado envolvendo participação detida pelo Sr. Nelson Tanure no capital social da HRT Participações em Petróleo S.A. (HRT). Conforme notícias divulgadas no mercado ${ }^{53}$, a partir de novembro de 2013, Tanure iniciou processo de aquisição de ações da companhia no mercado e, de acordo com dados fornecidos pela BMF\&BOVESPA ao mercado, na data-base de 31 de janeiro de 2014, o empresário já detinha, por meio de sua sociedade controlada, Jg Petrochem Participações Ltda., participação de $19.25 \%$ do capital da HRT, figurando como maior acionista da companhia, seguida pelo fundo de investimentos Discovery Capital Management LLC, titular de $17.71 \%$ do capital social total.

Listada no Novo Mercado, a HRT teve sua crise iniciada em 20 de dezembro de 2013, quando expôs ao mercado uma intensa disputa pelo controle da empresa. Em reunião de Conselho de Administração, convocada às pressas, quatro integrantes do órgão aliados a Márcio Mello, ex-diretor presidente e fundador da companhia, apresentaram pareceres jurídicos dando conta de que outros dois membros do Conselho de Administração e os dois conselheiros fiscais estavam atuando em conflito por já operarem em companhias concorrentes da HRT.

Na referida reunião do Conselho de Administração da HRT, que contava com a presença de apenas seis dos dez conselheiros que compõem o órgão, deliberou-se por afastar os membros supostamente em conflito e anular a instalação do conselho fiscal, bem como adiar a realização de Assembleia Geral Extraordinária a ser realizada, em primeira convocação, no dia 15 de janeiro de 2014. Em reação, seis conselheiros renunciaram aos

\footnotetext{
${ }^{53}$ Nesse sentido: CONSELHEIROS da HRT fazem queixa à CVM. Jornal Valor Econômico, 2 jan. 2014. Disponível em: <http://www.valor.com.br/empresas/3382906/conselheiros-da-hrt-fazem-queixacvm\#ixzz2pEZoHj7g>. Acesso em: jan. 2014; FUNDADOR quer adiar assembleia da HRT para ganhar tempo. Jornal Valor Econômico, 3 jan. 2014. Disponível em: <http://www.valor.com.br/empresas/3383956/fundador-quer-adiar-assembleia-da-hrt-para-ganhartempo\#ixzz2pKgIRzNQ>. Acesso em: jan. 2014; FIGUEIRAS, Maria Luíza. Para Nelson Tanure, quanto pior, melhor. Revista EXAME, 31 jan. 2014. Disponível em: <http://exame.abril.com.br/revistaexame/edicoes/1058/noticias/quanto-pior-melhor-2>. Acesso em: jan. 2014.
} 
seus respectivos cargos, remanescendo o órgão com apenas quatro membros em posse de seus cargos, em detrimento do disposto mínimo de cinco membros exigido no estatuto social da companhia.

O conflito na esfera administrativa foi suficiente para que sua origem logo se tornasse pública. Nos termos do edital de convocação publicado pela companhia em 13 de novembro de 2013, propôs a administração que a Assembleia Extraordinária fosse realizada para deliberar, entre outros itens, sobre a seguinte ordem do dia:

\footnotetext{
Remover o artigo 41, parágrafo $1^{\circ}$ e o artigo 44 e seus parágrafos do Estatuto Social da Companhia, a fim de extinguir a obrigação de realizar ou requerer o registro de uma oferta pública de aquisição, nos casos de aquisição de ações representativas de $20 \%$ (vinte por cento) ou mais do capital social da Companhia.
}

Tal como BRF, a HRT, nos termos das informações divulgadas pela companhia em seu Formulário de Referência de 2013 (linha 56, Tabela 2 - Apêndice B), não possui qualquer acionista controlador, sendo classificada, com base nesse critério, como companhia de capital pulverizado. Dessa forma, presume-se que a pílula de veneno presente em seu estatuto social seria poison pill clássica, inserida no estatuto social para proteger a permanência da administração na companhia.

Além da retirada da pílula de veneno do estatuto social, constatou-se que, dias antes da reunião do conselho realizada em 20 de dezembro de 2013, os conselheiros fiscais solicitaram a inclusão, entre os itens constantes da ordem do dia da Assembleia Geral a ser realizada, a apreciação da legalidade de plano de remuneração aprovado pela HRT no início do ano de 2013. Em termos gerais, o referido plano continha cláusula de garantia da eleição dos membros à administração da companhia, cabendo direito à indenização, quando estes não fossem eleitos, tal como ocorreu quando Marcio e sua irmã, Maria Emilia Mello, na Assembleia Geral Ordinária de 2013, surgindo então a disputa entre o fundo Discovery e a família Mello.

O cenário acima evidencia o claro interesse privado de Marcio Mello em manter-se no comando da administração da companhia, evitando, de um lado, que o Discovery se componha com outros acionistas e forme bloco de controle com participação superior à acumulada por Mello e, de outro, evite a reavaliação do plano que lhe conferiu o direito de receber indenização.

O futuro dessa briga societária ainda é incerto. Em 17 de janeiro de 2014, foi 
publicado novo edital de convocação de Assembleia Geral Extraordinária, para a qual, desta vez, foi proposta apenas a seguinte ordem do dia, tendo sido também publicado pedido público de procuração:

i. Reduzir o número de membros do Conselho de Administração da Companhia de 11 (onze) para 7 (sete); ii. Eleger os membros do Conselho de Administração da Companhia, incluindo o Presidente e o Vice-Presidente do Conselho, e iii. Eleger os membros do Conselho Fiscal da Companhia.

Destaca-se que na mesma data de veiculação do edital, a administração da companhia divulgou pedido público de procuração, nos termos da ICVM 481, tendo sido apresentado no pedido esclarecimento pela companhia, nos seguintes termos: "O pedido de procuração foi promovido pela administração da Companhia e será custeado integralmente pela Companhia, como prevê o art. 29 da Instrução CVM n⿳ำ 481/09”.

A ginástica de Mello, aliado a Nelson, para permanecer no comando das atividades sociais, traz à baila, mais uma vez, a importância de existirem critérios bem definidos para a identificação do poder de controle manifestado mediante titularidade de participação minoritária.

Nesse contexto, questiona-se a habilidade da Lei das S.A. para efetivamente disciplinar a realidade latente entre as companhias listadas no Novo Mercado. Sem menos importância do que a problemática identificada para a aplicação da obrigação prevista no artigo 254-A da Lei das S.A. ao instituto do controle minoritário, destaca-se, primeiramente, a imputação de deveres e responsabilidades ao acionista detentor do controle não majoritário, consoante disposto nos artigos 116 e 117 da Lei das S.A.

\subsection{Requisitos Legais}

Uma vez reconhecida, na prática, a existência de influência relevante exercida por acionistas não majoritários sobre a condução das atividades sociais, propõe-se, no presente capítulo, a análise do instituto do controle minoritário e sua inclusão no ordenamento jurídico brasileiro.

Conforme destacado anteriormente, controla a companhia aquele que conduz as atividades sociais e a estrutura de sua administração, mas, para tanto, depende da 
assembleia geral como meio para fazer valer a sua vontade. A lei não atribui ao titular de ações o direito de comandar a companhia, apenas confere ao acionista o direito de voto e determina que o poder decisório da assembleia geral se dará por maioria.

Nesse contexto, Comparato e Salomão Filho (2005, p. 39) apresentam importante questionamento sobre as acepções de soberania da assembleia geral e de exercício do poder de comando:

[...] na pesquisa da realidade de poder, na sociedade anônima, não podemos contentar com a afirmação legal de que "a assembleia geral, convocada e instalada de acordo com a lei e o estatuto, tem poderes para decidir todos os negócios relativos ao objeto da sociedade e tomar as resoluções que julgar convenientes à sua defesa e desenvolvimento" (Lei no 6.404, art. 121). Quem toma, de fato, as decisões em assembléia? O controle manifesta-se através dos poderes decisórios da assembléia de acionistas como necessária legitimação do seu exercício. Mas essa legitimação é meramente formal ou procedimental.

Em sentido amplo, o poder de controle pode ser definido como dominação, entendido, portanto, como capacidade detida por alguém de exercer comando sobre outrem. Logo, no campo do Direito Societário, especialmente no tocante às sociedades por ações, depreende-se como acionista controlador (titular do poder de controle) aquele que possui capacidade para comandar as atividades sociais, impondo sua vontade aos demais acionistas detentores do capital remanescente.

Ao analisarem o conceito e os requisitos para a configuração do poder de controle, ensinam os autores da Lei das S.A., Lamy Filho e Bulhões Pedreira (1996, p. 620):

[...] O poder de controle da companhia não é poder jurídico contido no complexo de direitos da ação: cada ação confere apenas o direito (ou poder jurídico) de um voto. O poder de controle nasce do fato da reunião na mesma pessoa (ou grupo de pessoas) da quantidade de ações cujos direitos de voto, quando exercidos no mesmo sentido, formam a maioria nas deliberações da Assembleia Geral. A natureza de fato do poder de controle fica evidente quando se considera que: a) não há norma legal que confira ou assegure poder de controle: esse poder nasce do fato da formação do bloco de controle e deixa de existir com o fato da sua dissolução; b) poder de controle não é direito subjetivo: o acionista controlador não pode pedir a tutela do Estado para obter que esse poder seja respeitado, a não ser quando se manifesta através do exercício regular do direito (ou poder jurídico) de voto nas deliberações da Assembleia Geral; c) o poder de controle não é objeto de direito: não pode ser adquirido nem transferido independentemente do bloco de controle, que é a sua fonte. $\underline{\mathrm{O} \text { acionista }}$ controlador (ou a sociedade controladora) não é, portanto, sujeito ativo de poder de controle: tem ou detém esse poder enquanto é titular (ou sujeito ativo) de direitos de voto em número suficiente para lhe assegurar a maioria das deliberações na Assembleia Geral [...]. (grifo nosso) 
Da análise dos dados obtidos na pesquisa empírica apresentada no Capítulo 3 da presente dissertação, nota-se uma clara influência de comando exercida por acionistas detentores de participação não majoritária. Parte-se, nesse sentido, à verificação do tratamento atribuído a tais acionistas em lei e pela doutrina, bem como dos eventuais requisitos necessários para que sejam configurados como acionistas controladores.

Com o objetivo de inserir, de forma precisa, o conceito de acionista controlador no ordenamento jurídico brasileiro, o legislador contemplou na Lei das S.A. ampla acepção, ao defini-lo, em seu artigo 116, como pessoa, ou grupo de pessoas, vinculada por acordo de acionistas ou sob controle comum que

a) é titular de direitos de sócio que lhe assegurem, de modo permanente, a maioria dos votos nas deliberações da assembléia-geral e o poder de eleger a maioria dos administradores da companhia; e b) usa efetivamente seu poder para dirigir as atividades sociais e orientar o funcionamento dos órgãos da companhia.

Dentre os requisitos apresentados acima para a configuração do acionista controlador, a alínea "a" do artigo 116 exige a titularidade de direitos que garantam a ele a maioria dos votos nas deliberações sociais e o poder de eleger a maioria dos administradores. Sobre o preenchimento do último requisito, à luz do poder de veto nas diversas formas de golden shares, Pela (2012) chama atenção para a dificuldade de se verificar a preponderância permanente na eleição de administradores, propondo a análise casuística da dinâmica e do histórico das deliberações sociais para preenchimento integral do requisito constante da alínea "a".

Sobre a necessidade de preenchimento de ambos os requisitos apresentados na alínea "a" do artigo 116 da Lei das S.A., Carvalhosa (2005) defende que estes não devem ser lidos como critérios cumulativos, já que é possível exercer o controle interno da companhia com apenas um dos atributos (maioria dos votos nas deliberações sociais ou poder de eleger a maioria dos administradores). Sobre esse entendimento, assinala Macedo (2004, p. 83):

Como, de fato, é de ser reconhecida a relevância da prerrogativa de eleição dos administradores da companhia como dado indicativo de uma possível situação de controle, deve-se reconhecer, por consequência, a irrelevância da forma donde emerge essa prerrogativa, pelo que, nesse ponto, parece acertada a visão de Carvalhosa no sentido de não tomar em senso literal a conjugação aditiva que consta da primeira alínea do artigo 116 da lei societária. Nada obstante, isso não importa dizer que, sempre que haja segmentação das prerrogativas descritas naquela alínea, o acionista ou grupo de acionistas que venha a assistir a primeira delas (i.e., titularidade da maioria de votos nas deliberações da assembleia geral [...]) poderá ser invariavelmente classificado como controlador ao lado daquele que detenha a prerrogativa eletiva. 
No mesmo sentido, Borba (2009), ao sustentar que o critério da permanência não se funda, necessariamente, na maioria do capital votante e sim na maioria dos acionistas presentes, propõe a verificação da permanência no histórico das assembleias, em função do nível de comparecimento, o que se ajustaria, até mesmo, à inclusão do conceito de controle minoritário na definição dada em lei.

A “difícil aferição em abstrato", ressaltada por Pela (2012), também se evidencia quando da análise do requisito apresentado na alínea "b" do mesmo artigo: uso efetivo do poder de controle. Fonte de diferentes posições doutrinárias, o requisito da efetividade divide a doutrina quanto a sua aplicabilidade na configuração do acionista controlador.

Segundo Carvalhosa (2003), o exercício efetivo do poder de controle é o terceiro requisito fundamental e indispensável da caracterização do acionista controlador (em complemento aos dois apresentados na alínea “a”, tidos pelo autor como não cumulativos), por se tratar da efetividade na condução dos negócios sociais. Ressalta o autor que o controle deve ser tido como poder efetivo, não se tratando, portanto, de poder "potencial, eventual, simbólico ou diferido (CARVALHOSA ${ }^{54}, 1978$ apud PENTEADO, 1989).

Concordam com o entendimento de que o uso efetivo do poder de controle é elemento fundamental para a caracterização do acionista controlador, Guerreiro e Teixeira (1979), seja o acionista pessoa física ou jurídica. Vale destacar também a posição intermediária de Coelho ${ }^{55}$ (1987 apud PENTEADO, 1989), por meio da qual se entenderia a aplicabilidade do requisito de exercício efetivo do poder de controle para a caracterização de acionista pessoa física, sendo, portanto, dispensável na aplicação do disposto no artigo 116 da Lei das S.A. a sociedades ${ }^{56}$.

Comparato e Salomão Filho (2005), por sua vez, propõem que a leitura dos requisitos constantes do artigo 116 da Lei das S.A. não deve ser aditiva, de modo que a exigência pelo uso efetivo do poder de comando seja aplicada restritivamente, apenas a

\footnotetext{
${ }^{54}$ CARVAlHOSA, Modesto. Comentários à Lei de S/A. 1. ed., 1978. p. 126. v. 4.

55 COELHO, José Washington. A nova lei das sociedades anônimas interpretada. São Paulo, Resenha Tributária, 1987, p. 70.

${ }^{56}$ Sobre o tema, ressalta Macedo (2004, p. 85): “[...] não cremos seja lícito sustentar que a teleologia da função de balizamento do direito societário, construída a partir das normas inscritas no artigo 117 e no parágrafo único do artigo antecedente da lei das sociedades por ações, aponte à disciplina da conduta do titular de um 'status' subjetivo formal (i.e., o status do assim definido 'acionista controlador'), mas, sim, à disciplina de situações objetivas que, por opção político-legislativa, se presente evitar no ambiente do fenômeno empresarial.".
} 
situação em que não restar configurado o controle acionário por meio do preenchimento dos requisitos de pela permanência e estabilidade apresentados na alínea "a".

A aplicação restritiva do requisito constante da alínea "b" é pautada na presunção de titularidade do poder de controle pelo acionista detentor da maioria do capital social, de modo que a verificação do uso efetivo do poder de controle para classificação de acionista como controlador se faria necessária apenas no cenário de averiguação da existência do controle minoritário, já que, em razão da dispersão acionária, a preponderância nas deliberações sociais poderia mostrar-se ausente.

Com efeito, no âmbito do controle majoritário, em resposta aos que tendem a entender que o uso efetivo do controle deve estar presente para a caracterização daquele que detém maioria do capital social votante como acionista controlador, destaca-se que o mau uso ou desuso do poder de controle pelo acionista detentor da maioria do capital votante não deveria determinar seu status como não titular do poder de controle, pois, ainda que este se desinteresse pelas atividades da companhia investida, não poderia se desvincular do "fato de que o poder de comando se exerce em seu nome, ou por delegação sua, o que a tanto equivale" (COMPARATO; SALOMÃO FILHO, 2005, p. 87).

Nesse sentido, ressaltam Comparato e Salomão Filho (2005, p. 78): “A inexistência de direitos permanentes que assegurem a maioria nas deliberações sociais não descaracteriza o controle, apenas impõe uma aplicação seletiva do previsto no art. 117”.

Favorável à posição de que o uso efetivo do poder de controle deve se fazer prova apenas na identificação de controle minoritário, Penteado (1989) ressalta que sempre haverá presunção de comando na titularidade da maioria das ações com direito a voto. De modo a acomodar os argumentos contrários e em consideração à dificuldade apontada por Martins $^{57}$ (1984, p. 153 apud PENTEADO, 1989, p. 16) na "torturante prova" de que o acionista sob análise exerce efetivamente o poder de controle, propõe Penteado (1989, p. 16) a inversão do ônus da prova:

[...] esse óbice poderia ser contornado mediante a inversão do "onus probandi", no caso do controle majoritário: o detentor da maioria das ações com direito a voto somente se eximiria da responsabilidade atribuída por lei ao acionista controlador se provar que outrem, e não ele, exercita efetivamente o poder de comando.

\footnotetext{
${ }^{57}$ MARTINS, Frans. Direito societário. 1. ed. Forense, 1984. p. 153.
} 
Sobre o tema, posiciona-se, aqui, em consonância com a interpretação restritiva dada por Comparato e Salomão Filho (2005), incrementada pela brilhante solução dada por Penteado (1989), ao considerar que o uso efetivo do poder é presumido, cabendo, ao titular da maioria das ações com direito a voto, prova de que não exerce tal comando.

Corrobora esse entendimento a proposta de interpretação apresentada por Pereira (1995, p. 19):

[...] no caso do controle majoritário, o uso efetivo do poder é presumido, não de forma absoluta, mas com presunção iuris tantum, elidível por prova em contrário. Isso porque a aceitação da tese parece implicar que todo aquele que detém a maioria das ações com voto tem o dever legal de exercer o controle, de comandar (talvez devêssemos falar em ônus). Ou seja, a ninguém é lícito ter tal quantidade de ações e desinteressar-se da orientação da empresa. A solução não me parece má; é, ao contrário, justa e até moralizadora (impondo certos limites à especulação). Deveria haver, contudo, a explicação desse dever - o que, em absoluto não se dessume do art. 116 da lei societária como está redigido; a impressão que se colhe é a de que àquele que resolver assume o poder, que tenha em estado potencial, a este atribui a lei as funções sociais e empresariais do parágrafo único. Se o acionista majoritário prova que nada tinha que ver com a orientação da companhia e ignorava o desempenho dela, não vejo como achacarlhe a responsabilidade do art. 117. Se, todavia, estava a par da situação e tinha como evitar a má orientação, mas omitiu-se, responde pelo princípio geral do art. 159 do Código Civil.

A interpretação restritiva do artigo 116, ora proposta, apresenta importante relevância para este trabalho, pois resulta no reconhecimento implícito do instituto do controle minoritário em lei, sendo, portanto, atribuída a presunção do controle àquele que detém a maioria o capital social votante, diferentemente da legislação norte-americana, por exemplo, que confere presunção de controle ao acionista titular de participação minoritária (superior a $25 \%$ do capital social votante) $)^{58}$.

Nessa conjuntura, ainda que se tivesse adotado posição contrária à interpretação restritiva ora defendida, destaca-se que a presunção atribuída ao acionista controlador, por meio de tal interpretação, já é identificada na realidade das companhias listadas no Novo

\footnotetext{
${ }^{58}$ Control means the power to exercise a controlling influence over the management or policies of a company, unless such power is solely the result of an official position with such company. Any person who owns beneficially either directly or through one or more controlled companies, more than 25 per centum of the voting securities of a company shall be presumed to control such company. Any person who does not so own more than 25 per centum of the voting securities of any company shall be presumed not to control such company." (grifo nosso). Investment Company Act of 1940 (as amended through P.L. 112-90, approved January 3, 2012), Seção 2, item 9, p. 5. Disponível em: <http://www.sec.gov/about/laws/ica40.pdf>. Acesso em: 9 jul. 2012. Sobre o tema, Eizirik (2010, p. 180) reconhece que "o fato de o art. 116 não exigir um percentual mínimo de ações para permitir a identificação do acionista controlador, bem como subordiná-la ao efetivo exercício do poder de dominação, evidencia que a Lei das S.A. admitiu implicitamente a existência do controle minoritário.".
} 
Mercado, consoante definição atribuída pelo Regulamento de Listagem do Novo Mercado ao acionista controlador, ao determinar que há

\begin{abstract}
presunção relativa de titularidade do controle em relação à pessoa ou ao Grupo de Acionistas que seja titular de ações que lhe tenham assegurado a maioria absoluta dos votos dos acionistas presentes nas 3 (três) últimas assembleias gerais da Companhia, ainda que não seja titular das ações que lhe assegurem a maioria absoluta do capital votante.
\end{abstract}

A atual redação do regulamento baseia-se no texto da revogada Resolução CMN $\mathrm{n}^{\mathrm{o}} 401 / 1976^{59}$, que, em seu inciso "iv", atribuía presunção de controle minoritário ao grupo de acionistas vinculados por acordo de acionistas, ou sob controle comum, que, embora não fossem titulares de ações que lhes assegurassem a maioria absoluta dos votos do capital social, eram titulares de ações que garantiam "a maioria absoluta dos votos dos acionistas presentes nas três últimas Assembleias Gerais da companhia”.

Reformado em 2011, o regulamento do Novo Mercado estabelece, em seu item 2.1, que o poder de controle consiste naquele "efetivamente utilizado para dirigir as atividades sociais e orientar o funcionamento dos órgãos da Companhia, de forma direta ou indireta, de fato ou de direito, independentemente da participação acionária detida" (grifo nosso em destaque à inclusão feita em 2011) ${ }^{60}$, atribuindo às companhias listadas no Novo Mercado a presunção de controle minoritário (in verbis acima), tal como na legislação norteamericana, sem, no entanto, haver definição prévia de percentual de participação acionária para configuração o controle minoritário ${ }^{61}$.

Em linha com a existência implícita do controle minoritário no ordenamento jurídico brasileiro reconhecida por Comparato e Salomão Filho (2005), o regulamento do

59 A Resolução CMN no 401/1976 (disponível em: <http://www.cnb.org.br/ASPView/resolucoes.htm>, acesso em: 16 jul. 2012) foi editada pelo Banco Central do Brasil, em 22 de dezembro de 1976, com o objetivo de regular a aplicação do art. 254 da LSA, estabelecendo a obrigatoriedade de oferta pública de aquisição de ações pelo adquirente do controle de companhia aberta, a fim de adquirir as demais ações com direito a voto, conferindo aos demais acionistas tratamento igualitário ao do acionista controlador. Referida resolução restou revogada quando do advento da Lei n 9.457/1997 (Lei Kandir), que revogou o art. 254 da lei acionária. Vale mencionar que, em 2001, na reforma da Lei das S.A., realizada por meio da edição da Lei $\mathrm{n}^{\mathrm{o}}$ 10.303, de 31 de dezembro de 2011, a obrigatoriedade de realização de oferta pública pelo adquirente do controle de companhia aberta sob a condição, suspensiva ou resolutiva, foi reinserida no ordenamento jurídico societário brasileiro, pela inclusão do art. 254-A à Lei das S.A., de modo a assegurar aos demais acionistas (não alienantes do controle acionário) participação no prêmio de controle. No entanto, não foram reinseridos na Lei das S.A. dispositivos relacionados à presunção de controle minoritário, tal como originalmente estabelecido na revogada Resolução CMN no ${ }^{\circ}$ 401/1976.

${ }^{60}$ Regulamento de Listagem do Novo Mercado, item 2.1. Redação atualmente em vigor desde 10.05.2011 foi aprovada pela CVM em 21.03.2011, refletindo as alterações aprovadas em processo de audiência pública realizada junto às companhias listadas no segmento do Novo Mercado. Texto integral disponível em <http://www.bmfbovespa.com.br/Empresas/download/RegulamentoNMercado.pdf>. Acesso em 16.07.2012.

${ }^{61}$ Cabe mencionar aqui o conceito de participação relevante trazido pelo Código de Autorregulação do Comitê de Fusões e Aquisições (CAF), conforme será detalhado mais adiante. 
Novo Mercado incorpora a existência do controle minoritário ao criar elementos que facilitam a comprovação do uso efetivo do poder de controle para enquadramento do acionista controlador, sendo, para tanto, resgatados os critérios originalmente apresentados na revogada Resolução CMN nº 401/1976.

Em que pese doutrina contrária à interpretação restritiva dos requisitos constantes do artigo 116 da Lei das S.A., e consequente existência legal do controle minoritário ${ }^{62}$, entende-se como superada essa questão. Ora, ainda que por meio de interpretação restritiva da lei, tal entendimento resta por conferir maior segurança jurídica às relações societárias ao garantir amplitude ao conceito de acionista controlador suficiente para que seja caracterizado como tal não apenas o acionista detentor da maioria do capital votante, mas, também o que exerce comando sobre as atividades sociais e os órgãos da administração, mesmo que mediante participação não majoritária no capital votante.

Com base nos elementos apresentados nos capítulos anteriores, em especial a verificação de existência prática do controle minoritário, considera-se que o instituto do controle minoritário insere-se no ordenamento jurídico brasileiro, não sendo identificadas restrições legais para a sua consideração pelos operadores do Direito Societário. Como consequência, o acionista configurado controlador minoritário restará sujeito aos deveres atribuídos ao acionista controlador, consoante parágrafo único do artigo 116 da Lei das S.A., bem como às responsabilidades impostas no artigo 117 da lei acionária ${ }^{63}$.

Comparato e Salomão Filho (2005, p. 65 e ss.) defendem o reconhecimento implícito do controle minoritário em lei, ao serem fixadas regras de quórum e maioria na dinâmica da assembleia geral. Não obstante, os autores destacam que o legislador

\footnotetext{
${ }^{62}$ Com base nos requisitos expressamente previstos no artigo 116 da Lei das S.A., Carvalhosa (2011a, p. 2425) adota posição contrária à configuração do controle minoritário e sustenta que a dispersão acionária resultaria apenas no controle gerencial, de modo que, nesse caso, o poder de controle deixaria de ser exercido por acionista e passaria à administração da companhia, consequentemente, o atendimento ao requisito de permanência deixaria de ser aplicável. Apesar disso, diante da evolução das sociedades por ações brasileiras, na última década, e o fenômeno de dispersão acionária, tantas vezes ressaltado, o próprio autor reconhece, quando da análise do processo de abertura de capital e alistamento no Novo Mercado: "Daí resulta que os antigos controladores perderam a maioria absoluta votante do capital social, agravada essa perda pela venda de grande parte de suas ações nas auspiciosas e conspícuas operações secundárias de Oferta Inicial de Venda (IPOs). Reduzidos, assim, os antigos controladores a uma posição minoritária no capital social - todo ele votante - criaram em torno deles próprios a pseudoimagem de 'controladores minoritários', além de se protegerem estatutariamente com as chamadas 'poison pills"”.

${ }^{63}$ Nos termos do parágrafo único do artigo 116, da Lei das S.A., o controlador deve "usar o poder com o fim de fazer a companhia realizar o seu objeto e cumprir sua função social, e tem deveres e responsabilidades para com os demais acionistas da empresa, os que nela trabalham e para com a comunidade em que atua, cujos direitos e interesses deve lealmente respeitar e atender". O artigo 117 da Lei das S.A. imputa ao controlador o dever de responder pelos danos decorrentes de atos praticados com abuso de poder, apresentando relação de práticas que devem ser entendidas como exercício abusivo de poder.
} 
brasileiro, diferentemente do que ocorre em algumas legislações estrangeiras, limitou-se a admitir a possibilidade de um controle minoritário de forma implícita, não havendo, portanto, presunção do controle minoritário, uma vez enquadradas determinadas circunstâncias.

Como regra, o artigo 125 da Lei das S.A. determina que a assembleia geral se instale, em primeira convocação, mediante presença de acionistas que representem, no mínimo, um quarto do capital social com direito a voto e, em segunda convocação, com qualquer número. Exceção é feita a quórum qualificado de dois terços do capital votante para a instalação, em primeira convocação, de assembleias que tratem de reforma do estatuto, podendo a reunião ser instalada com qualquer número de ações em segunda convocação, conforme o disposto no artigo 135, da Lei das S.A. ${ }^{64}$.

Nesse contexto, destaca-se que o diploma acionário prevê, para companhias abertas com propriedade acionária dispersa e cujas três últimas assembleias tenham sido realizadas com a presença de acionistas representando menos da metade das ações com direito a voto, a possibilidade de redução do quórum qualificado para deliberações da assembleia geral, mediante autorização da CVM (artigo 136, parágrafo $2^{\circ}$, da Lei das S.A.).

Referido dispositivo, ainda que eventualmente redigido e incorporado à Lei das S.A., sob a ótica de companhia com capital pulverizado, traz à baila a possibilidade de manifestação plena do controle minoritário, sobretudo considerando-se os índices de dispersão acionária das companhias listadas no Novo Mercado, tal como demonstrados no Apêndice B.

Nesse sentindo, concluem os referidos autores:

\begin{abstract}
A rigor, um controle minoritário bem estruturado, em companhia com grande pulverização acionária, pode atuar com a mesma eficiência que um controle majoritário. Mas a lei brasileira estabelece uma distinção importante, ao impor para a aprovação de certas deliberações o concurso de voto de metade, no mínimo, do capital com direito a voto. (COMPARATO; SALOMÃO FILHO, 2005, p. 67)
\end{abstract}

\footnotetext{
64 Sobre o tema, destaca-se que a CVM tem concedido o pedido previsto no apresentado dispositivo legal. Como regra, a companhia em questão deve comprovar que efetivamente teve dificuldade em atingir o quórum legal e envidar esforços adicionais para garantir maior participação dos acionistas nas companhias. Nesse sentido, vide decisões proferidas nos seguintes julgamentos, envolvendo, em sua maioria, companhias listadas no Novo Mercado: Processo CVM no RJ 2008/9337 (Banco Indusval S.A. - Nível 2), Processo CVM $\mathrm{n}^{\mathrm{o}}$ RJ 2007/0947 (Iochpe Maxion S.A. - Novo Mercado), Processo CVM nº RJ 2009/10433 (Paranapanema S.A. - Novo Mercado), Processo CVM no RJ 2010/10723 (ALL América Latina Logística S.A. - Novo Mercado), Processo CVM no RJ 2011/9443 (Mundial S.A. - Produtos de Consumo - Segmento tradicional), e Processo CVM nº RJ 2012/6610 (MMX Mineração e Metálicos S.A. - Novo Mercado).
} 
Segundo Prado (2005, p. 135), controle minoritário é controle que se manifesta quando está ausente na companhia acionista capaz de reunir, sob seu comando, participação acionária suficiente para configurar o princípio majoritário, ou, sendo este presente, quando tal acionista não exerce efetivamente o controle nas deliberações assembleares.

Biana (2011, p. 29) classifica o controle minoritário em: (i) espontâneo, quando o poder de comando decorre exclusivamente de situações cotidianas de realocações de posições acionárias; e (ii) induzido, quando manifestado por meio disposições estatutárias, como as poison pills, que podem perpetuar o controle minoritário induzido. Destaca, ainda, que poderá o controle minoritário ser unipessoal ou plural, havendo, no último, a convergência de interesses distintos sob mesmo prisma, como, por exemplo, especuladores e acionistas de longo prazo que poderão tomar decisões conjuntas, todavia com propósitos finais totalmente divergentes.

Importante destacar, ainda, que essa espécie de controle poderá ser identificada em grupamento de acionistas unidos por acordos que acabem por criar um bloco majoritário do capital votante em assembleias gerais (controle compartilhado). O controle minoritário poderá ser exercido, portanto, por mais de um acionista, havendo situações em que grupos de acionistas com interesses distintos se organizem com o objetivo de constituir um bloco de controle, mediante acordos parassocietários (i.e., acordo de acionistas e acordo de voto), de forma que exerçam, em conjunto, o poder de controle sobre da companhia.

À luz do Direito Comparado, Berle e Means (1968, p. 75) definem como controle minoritário aquele existente quando

[...] an individual or small group hold a sufficient stock interest to be in a position to dominate a corporation through their stock interest. Such a group is often said to have "working control" of the company [...], this means that no other stockholding is sufficiently large to act as nucleus around which to gather a majority of the votes.

Nesse sentido, cita-se, ainda, Lucena (2009, p. 1080):

A norma não fixa, assim, um quantitativo de ações votantes para a assunção do status de controlador, exatamente porque, conforme o caso, o controlador será o acionista que detém quase todas as ações da companhia ou qualquer percentual acima de $50 \% \%$ do capital votante, como poderá ser o acionista minoritário que, devido das ações reúne um número de ações (suas ou de um grupo) suficiente, abaixo da metade do capital social votante, para assumir o controle da assembleia geral e, decorrentemente, o da companhia (working control). 
Importante salientar que, além da dispersão acionária e da manifestação do controle minoritário em companhias de capital relativamente disperso, o absenteísmo nas assembleias gerais também possui papel decisivo para o surgimento do controle minoritário, pois, conforme ressaltado por Lucena (2009, p. 1.077 e ss.), com o seu advento, as deliberações assembleares restam aprovadas por grupo não majoritário ativo.

Sobre o absenteísmo decorrente da própria dispersão acionária e a possibilidade de surgimento do controle minoritário, Borba (2009, p. 348) discorre:

\footnotetext{
Essa ausência que, em muitos casos, se estende à maioria das ações faz com que às assembléias apenas compareça uma parcela minoritária do capital votante. Nestas circunstâncias, a maioria será apurada em relação a esse grupo ativo, o que possibilita a polarização do controle na maioria dos presentes. Se o grupo ativo que costuma comparecer à assembleia representar, por exemplo, dezoito por cento do capital votante, o acionista que contar com nove por cento do capital mais uma ação terá o controle da companhia. A essa forma de controle, apoiada em menos de cinquenta por cento do capital, dá-se o nome de controle minoritário.
}

Diante do exposto, cabe o reconhecimento de um controle atualmente exercido por participações minoritárias relevantes, de forma que tais acionistas não estejam alheios às regras que lhes são aplicáveis na qualidade de acionistas controladores. Ressalta-se, no entanto, que, apesar de o legislador ter reconhecido implicitamente o instituto do controle minoritário, não estabeleceu critérios objetivos para a sua identificação. Nota-se que tal conceito foi incorporado pela Lei das S.A. em torno da figura do acionista controlador majoritário, sem atenção objetiva para a efetiva configuração de um controle interno minoritário.

Nesse contexto, a difícil prova em abstrato para confirmação do exercício do efetivo do poder de controle permanece presente na devida apuração do controle minoritário. Dessa forma, analisam-se a seguir os requisitos complementares que poderiam ser considerados pelo legislador e pelos aplicadores do Direito Societário quando da análise de questões envolvendo o exercício do controle societário.

\subsection{Requisitos Complementares}

Reconhecida a existência prática do instituto do controle minoritário e confirmado o seu reconhecimento pelo ordenamento jurídico brasileiro, tal como demonstrado nos 
capítulos anteriores, questiona-se a eventual necessidade de utilização de critérios adicionais para a identificação do acionista controlador minoritário.

Seguindo o raciocínio de que é controlador minoritário aquele que exerce efetivamente "seu poder para dirigir as atividades sociais e orientar o funcionamento dos órgãos da companhia", surge questão apresentada alhures sobre a dificuldade de se comprovar o exercício efetivo do controle.

Conforme destacado por Oioli (2011, p. 321), "sendo o controle minoritário um controle de 'fato', sua caracterização ou não carrega consigo uma grande carga de insegurança jurídica”. Seria, então, possível determinar critérios objetivos que uma vez atingidos configurassem por completo o acionista controlador minoritário?

Embora a lei das S.A. não apresente elementos objetivos que facilitem tal comprovação, entende-se que tal confirmação se daria por meio da aplicação dos mesmos conceitos que levam à comprovação de preponderância nas assembleias gerais, consoante disposto no artigo 116, "a", da Lei das S.A., ou seja, a análise se daria por meio da identificação da predominância da vontade do acionista controlador minoritário sobre as deliberações assembleares constatando-se, consequentemente, o seu domínio sobre a condução das atividades sociais e organização e funcionamento da administração da companhia.

Nesse sentido, assinala Bocater (2012, p. 836):

\footnotetext{
Apesar das dificuldades de se identificar, nas hipóteses de dispersão acionária, se há um núcleo de controle na companhia, em diversos casos detectar, pelo exame da prevalência de votos nas assembleias ao longo de determinado período de tempo, aliado a outros elementos que possam evidenciar a existência de vínculos, acordos tácitos, ou imbricação de interesses, se há um acionista, ou grupo de acionistas, que exerça de fato o controle. (grifo nosso)
}

A sugestão apresentada pela referida autora nos refuta aos resultados obtidos na pesquisa empírica elaborada no curso da presente dissertação. Nas etapas descritas nos itens 3.3.3. e 3.3.4, buscou-se identificar artifícios de entrincheiramento eventualmente utilizados por acionistas para a manutenção do controle societário, mesmo que após sua eventual diluição para participação minoritária, apurando-se, respectivamente, (i) a existência de acordos de acionistas celebrados com o propósito de comando, isto é, aqueles decorrentes da dispersão acionária e consequente aglutinação dos acionistas em torno de interesse comum, bem como a presença de pílulas de veneno em seus respectivos estatutos 
sociais, que caracterizassem a estrutura das famosas pílulas de veneno brasileiras (vide dados consolidados nos Apêndices D e E).

Naquele momento, dentre as 28 companhias listadas no Novo Mercado com estrutura acionária relativamente dispersa (Grupo A), 20 divulgaram à CVM a existência de acordos de acionistas que tratassem sobre temas relacionados a essas sociedades. No entanto, dez acordos apresentaram todos os critérios considerados para a sua classificação como acordo de comando, a saber: (i) cláusulas que disciplinam sobre a realização de reuniões prévias para o exercício do direito de voto e condução das atividades sociais; (ii) cláusulas referentes à indicação de membros para compor o conselho de administração; e (iii) cláusulas referentes à vinculação dos administradores ao disposto no acordo em questão.

Destaca-se, porém, que embora a verificação se demonstre efetiva para a identificação de determinados grupos familiares que atuam por meio do controle minoritário compartilhado, a existência de acordo de acionistas de comando não se mostrou efetiva como critério objetivo de reconhecimento de todo e qualquer acionista controlador minoritário, posto que nem sempre as convenções entre acionistas encontramse lavradas em instrumento próprio, ainda que sob pena de não serem tuteladas pela execução específica e perderem as garantias de efetivação do disposto no acordo, conferidas em lei.

Conforme assinala Bertoldi (2000, p. 74):

\begin{abstract}
Essa reunião de acionistas em torno de um objetivo comum não precisa necessariamente ser formalizada nos termos do artigo 118 da Lei das S/A, pois a lei admite a existência do acionista controlador de fato. Ou seja, sempre que dois ou mais acionistas estabeleçam regras de conduta para o exercício do direito de voto na assembleia de forma a imprimir sua vontade diante daquele órgão social identifica-se ai o poder de controle. [...] Como vimos o acordo entre os acionistas, que acaba por formalizar um grupo de controle, não necessariamente precisa ser arquivado na companhia.
\end{abstract}

Não obstante, com o propósito de adicionar elemento decisivo para a identificação de eventual presença de acionista controlador minoritário em companhias que tenham seus acordos de acionistas arquivados na sede social, procedeu-se à análise da eventual existência de pílulas de veneno nos estatutos sociais das 20 companhias do Grupo A nas quais se verificou a presença de acordos de acionistas. 
Como resultado, observou-se que, das 15 pílulas de veneno identificadas na amostra coletada, 11 possuíam mecanismo de exceção da obrigatoriedade de realização da OPA por aquisição de participação relevante para as participações que tivessem sido adquiridas e/ou acumuladas antes do registro da companhia junto à CVM, destacando-se que, dentre as 11 companhias citadas, 9 apresentaram percentual de gatilho inferior ao de participação detido pelo bloco de controle.

O resultado acima demonstra clara tendência da presença de um bloco controlador minoritário nas nove companhias; no entanto, para conferir maior segurança jurídica, a análise deve se dar em conjunto com a celebração de acordo de acionistas e outros elementos que confiram maior certeza sobre a classificação do controle.

Com base nisso, tender-se-ia a defender que o elemento objetivo pelo qual se partiu em busca se daria mediante a combinação/cumulação de determinados critérios objetivos. Contudo, com base nas informações das companhias objeto de análise, nota-se que não há um padrão claro de preenchimento de critérios objetivos que possa ser considerado como elementar para a caracterização do controle minoritário. A exemplo, cita-se o caso da Indústrias Romi S.A., que, a despeito de ter apresentado em seu estatuto social pílula de veneno nos termos acima e seu acionista controlador deter participação inferior ao percentual tido como relevante, seu acordo de acionistas não apresentou cláusulas que disciplinassem sobre a eleição da administração, o que o levaria facilmente a ser classificado como acordo de comando - o que de fato aconteceria, mas apenas após análise detalhada do conteúdo das informações apresentadas no acordo de acionistas arquivado na sede social, combinada com a distribuição do capital social entre familiares e outros fatores, tal como detalhado alhures.

Ressalta-se que, mesmo não sendo a análise combinada dos critérios de acordo de comando e de pílula de veneno suficiente para abranger todas as configurações em que se pode dar o controle minoritário, ela se mostrou efetiva para a confirmação do controle minoritário nas nove companhias apontadas acima. No entanto, além da devida segurança jurídica na atribuição do status de controlador a determinado acionista, a sua efetivação se mostra pouco eficiente na prática por demandar análise casuística apurada, mediante levantamento e processamento de grande volume de informações correlatas.

Tais constatações comprovam a necessidade de requisito objetivo que permita a efetiva identificação do acionista controlador, conferindo, consequentemente, maior eficácia ao disposto no artigo 116 da Lei das S.A. 
Conforme demonstrado no capítulo 4.2, as maiores discussões práticas sobre a definição do controle minoritário surgem em decorrência da aplicação do disposto no artigo 254-A, que estabelece relevante obrigação a ser cumprida por acionistas adquirentes do controle societário. Nesse contexto, uma alternativa que vem sendo recentemente discutida como elemento objetivo de identificação do controle societário, principalmente para fins de aplicação do disposto no referido artigo, é a presunção do controle societário com base em percentual de participação preestabelecido, de modo que haja uma participação societária que seja um divisor de águas entre o controle societário interno e a participação não controladora.

A presunção de controle com base em percentual predeterminado é estrutura comumente identificada no Direito Comparado. Além da presunção de controle fixada em 25\% do capital votante nos Estados Unidos (conforme Investment Company Act of 1940, Seção 2, item 9), outros países, como Alemanha, Itália e Reino Unido, adotam o percentual de $30 \%$, de modo a garantir maior objetividade à identificação do acionista controlador para fins de aplicação das obrigações previstas nos respectivos ordenamentos (COMPARATO; SALOMÃO FILHO, 2007; MUNHOZ, 2012).

Ainda que a CVM não tenha se posicionado diretamente sobre o tema, a então diretora presidente da autarquia, Maria Helena dos Santos Fernandes de Santana, ao analisar o eventual disparo da obrigação de realização de oferta pública de corrente da aquisição do controle indireto da Tim Participações S.A., no âmbito do Processo CVM RJ 2007/14344 (detalhado alhures), mostrou-se, em voto proferido em 15 de julho de 2009, favorável à adoção de percentual de $30 \%$ do capital social votante como referência para a presunção do controle, sugerindo-o como representativo do controle minoritário de sociedades em que não haja outro acionista detentor de um bloco de ações maior que esse:

\footnotetext{
Entendo, por isso, que é fundamental o esforço de construção de critérios que permitam tornar mais previsível e segura a avaliação a ser feita nos casos concretos. E para que se possa evitar a excessiva subjetividade de análises puramente casuísticas, sou de opinião que o mais conveniente seria a adoção do percentual de $30 \%$ do capital votante, presumindo-o como representativo do controle minoritário de sociedades em que não haja outro acionista detentor de um bloco de ações maior que esse. Mas a discussão sobre qual seria a melhor baliza ainda deve ser muito aprofundada, bem como a avaliação sobre que mecanismos haveria, à disposição da CVM, para adotar essas definições.
}

Como a decisão da diretora presidente se pautou pela aplicabilidade de legislação estrangeira ao caso, sua opinião favorável à fixação de percentual específico para a presunção de controle não representou uma orientação da autarquia sobre o tema. 
Nesse contexto, destaca-se a criação do Comitê de Aquisições e Fusões (CAF), após a celebração de convênio entre a Associação dos Apoiadores do CAF e a CVM, em 27 de agosto de 2013, que evidenciou demanda do mercado pela adoção de instrumentos que facilitem o reconhecimento de uma participação minoritária relevante. De adesão voluntária $^{65}$, o objetivo principal da criação do comitê era desenvolver uma versão nacional do instituto do Take Over Panel inglês, de forma a proporcionar às companhias abertas a possibilidade de submissão voluntária à autorregulação, aderindo um rígido sistema de governança corporativa, que conferiria maior segurança aos seus acionistas.

Dentre as disposições inseridas no Código de Autorregulação de Aquisições e Fusões, merece atenção especial o disposto em seu artigo 65, por meio do qual se estabelece que o acionista ou grupo de acionistas que atingir, direta ou indiretamente, ações com direito a voto, em percentual igual ou superior ao fixado no estatuto social da companhia aderente (o qual não poderá ser inferior a $20 \%$ nem superior a $30 \%$ do seu capital votante), por meio de única ou de diversas operações, deverá divulgar fato relevante sobre tal operação e efetivar oferta pública de aquisição de todas as demais ações e valores mobiliários conversíveis em ações de emissão da companhia.

O referido percentual e a estrutura de criação de obrigação de realização de OPA por adquirente de participação relevante já haviam sido base de discussão no mercado na ocasião da revisão da minuta do novo Regulamento de Listagem do Novo Mercado elaborada pela BM\&FBOVESPA e divulgada pela Diretoria de Relações com Empresas da BM\&FBOVESP, para fins da audiência restrita que seria realizada no período entre 7 de julho a 6 de agosto de 2010.

A minuta propunha, entre outras alterações, a inserção de definição de participação relevante para fins da regra de OPA por atingimento de participação acionária relevante, ou seja, "a titularidade de ações de emissão da Companhia correspondentes a, no mínimo, $30 \%$ (trinta por cento) do seu capital social”; porém, o texto foi excluído da redação quando da aprovação da versão final do novo Regulamento do Novo Mercado.

Nota-se na doutrina, todavia, movimento favorável à adoção do critério de fixação de percentual de participação tida como relevante para fins da obrigatoriedade de

\footnotetext{
${ }^{65} \mathrm{Na}$ data de elaboração da presente dissertação, apenas a apenas a BM\&FBOVESPA integrava o grupo de companhias que aderiram às regras do $\mathrm{CAF}$, sendo incerto, ainda, a adesão de outras companhias e o sucesso do comitê entre os operadores do mercado.
} 
realização de oferta pública por aquisição da participação predeterminada. Nesse sentido, defende Munhoz (2012, p. 356-357):

[...] é preciso no direito brasileiro definir um conceito específico de controle como referência das ofertas objeto dos arts. 254-A e 257 da Lei das S.A. e, ainda, da OPA do Novo Mercado. [...] Nessa linha, poderia ser alterada a redação do art. $3^{\circ}$, iv, da Instrução CVM no $361 / 2002$ para estabelecer que seria presumido como posição de controle, para efeito da OPA por alienação (ou por aquisição - art. 254-A) e da OPA para aquisição do controle (art. 257, § $2^{\circ}$, LSA), um percentual fixo de participação no capital votante.

Apesar de o conceito de participação relevante ter sido desconsiderado e a CVM não ter editado normas que permitam apuração objetiva do controle em companhias com capital disperso, destaca-se que a noção de participação relevante acaba sempre surgindo no âmbito da obrigatoriedade de realização de oferta pública por aquisição de tal participação, não como sugestão de método para a identificação do acionista controlador, nos termos previstos no artigo 116 da Lei das S.A.

Inclusive, nota-se certa divisão na doutrina, diante da aceitação da existência do controle minoritário e do elevado ônus imposto ao adquirente controle acionário da companhia aberta diante da obrigação prevista no artigo 254-A da Lei das S.A. O problema central surge do posicionamento sobre a imposição de tal pena apenas quando o ofertante se tornar titular de ações que lhe assegurem o exercício efetivo do controle, trazendo-se à questão a necessidade de certa estabilidade a tal exercício.

Eizirik (2010, p. 186-187) propõe interpretação relativa do artigo 116 da Lei das S.A., para fins de aplicação do disposto no artigo 254-A do mesmo diploma, defendendo que, para que se caracterize a alienação de controle objeto do artigo 254-A da Lei das S.A., é indispensável a efetiva titularidade do poder de controle, ou seja, o acionista ou o grupo de acionistas detentor de ações que represente menos do que $50 \%$ do capital social votante não seria titular do poder de controle para fins da obrigação do referido artigo, embora possa exercê-lo de fato, sendo considerado como acionista controlador para fins do disposto nos artigos 116 e 117 da Lei das S.A.

Já Oioli (2011, p. 322) defende, ao reconhecer a inclusão do controle minoritário (chamado pelo autor como controle diluído) da hipótese de incidência do artigo 254-A, que tal interpretação relativa não estaria prevista na Lei das S.A., não sendo, portanto, aceitável que o referido diploma trabalhe com conceitos distintos de acionista controlador, um para efeito do artigo 116 da Lei das S.A. e outro para efeito da obrigação imposta no artigo 254A da lei acionária. 
Ainda que sejam reconhecidos os custos impostos às operações de alienação de controle de companhias abertas ao se reconhecer a obrigatoriedade da OPA para alienação de controle minoritário (EIZIRIK, 2010), concorda-se com o posicionamento de Oioli (2011) de que a análise sistemática da lei resta por atribuir tal obrigação ao adquirente do poder de controle, seja tal poder majoritário ou não, posto que ambos os dispositivos centram-se no mesmo fundamento, o conceito de controle. Para tanto, parece acertada a sugestão de Munhoz (2012) apresentada alhures, como critério para determinação da OPA para aquisição de participação relevante.

Embora aparentemente solucionada a dúvida quanto ao reconhecimento do controle minoritário para efeito da obrigação imposta pelo artigo 254-A, permanece a insegurança quando à aplicabilidade do disposto nos artigos 116 e 117 da Lei das S.A., de modo a garantir a eficácia de tais dispositivos ao acionista detentor do controle minoritário.

Com base na pesquisa empírica desenvolvida na presente dissertação, ressalta-se que não foi possível identificar, entre as companhias listadas no Novo Mercado, eventual padrão para a determinação de um percentual que não gere insegurança quando de sua aplicação. Resgata-se que, da análise de cada uma das 28 companhias classificadas no Grupo A, foram observadas participações dos maiores acionistas controladores que variam de $6,48 \%$ a 47,02, representando uma média de participação conjunta controladora e não majoritária correspondente a $32,06 \%$ do capital social.

No âmbito das companhias listadas no Novo Mercado, o disposto na definição de poder de controle, empregada pelo Regulamento de Listagem do Novo Mercado para definir o acionista controlador, trouxe certo elemento de objetividade para a simples verificação do exercício efetivo do poder de controle e eliminou qualquer dúvida sobre o possível reconhecimento do controle minoritário pelo regulamento, confira-se in verbis:

\footnotetext{
"Poder de Controle" significa o poder efetivamente utilizado de dirigir as atividades sociais e orientar o funcionamento dos órgãos da Companhia, de forma direta ou indireta, de fato ou de direito, independentemente da participação acionária detida. Há presuncão relativa de titularidade do controle em relação à pessoa ou ao Grupo de Acionistas que seja titular de aç̃oes que the tenham assegurado a maioria absoluta dos votos dos acionistas presentes nas 3 (três) últimas assembleias gerais da Companhia, ainda que não seja titular das ações que lhe assegurem a maioria absoluta do capital votante. (grifo nosso)
}

Ora, no âmbito do controle minoritário exercido nas companhias listadas no Novo Mercado não pairam dúvidas de que o regulamento do Novo Mercado reconhece a 
existência desse controle ao destacar que o poder de comando sobre a companhia listada nesse segmento, de fato ou de direito, pode ser exercido independentemente da participação acionária na companhia, indo além ao apresentar a análise das deliberações assembleares como critério objetivo para apuração do exercício efetivo desse controle.

Nesse sentido, o regulamento atribui presunção de controle ao acionista cuja vontade preponderar nas últimas três assembleias gerais da companhia, considerando-se, para tanto, a maioria absoluta dos votos dos acionistas presentes, o que descarta, portanto, qualquer questionamento sobre a eventual interpretação do dispositivo sob a ótica da maioria do capital votante e quanto ao período necessário para apuração da predominância nas assembleias ${ }^{66}$.

A partir de tal reconhecimento, embora tenham sidos determinados critérios temporal e qualitativo, questiona-se o mecanismo mais adequado para que seja verificada a predominância nas deliberações sociais. Assim, cita-se esclarecimento apresentado por Borba (2009, p. 349), sobre como apurar a maioria de votos nas deliberações da assembleia geral:

\begin{abstract}
O que indica a maioria nas assembleias é a própria história das assembleias, em função do comparecimento que normalmente se verifica. O nível de presença mostrará a maioria necessária e, consequentemente, o titular do poder de controle.
\end{abstract}

Entende-se que a sugestão acima, ainda que esteja em linha com o critério de identificação do uso efetivo do poder de controle por meio da preponderância na assembleia geral, pode se mostrar insuficiente para a atribuição a determinado acionista como controlador, dada a dificuldade de comprovar tal preponderância com base apenas no nível de presença.

Receios surgem em função da simplicidade das informações apresentadas pelas companhias nas atas de suas respectivas assembleias gerais, por entender-se que estas não trariam as informações necessárias para a apuração do quórum de instalação da assembleia e, por conseguinte, verificação da maioria absoluta dos votos proferidos no respectivo conclave $^{67}$.

\footnotetext{
${ }^{66}$ Destaca-se que a presunção de participação relevante contida no Código do CAF é utilizada apenas no âmbito do estabelecimento da obrigatoriedade de condução de oferta pública de aquisição, sendo importante destacar que o referido diploma, ao definir acionista controlador e poder de controle, utilizou os mesmos critérios presentes no vigente Regulamento de Listagem do Novo Mercado.

${ }^{67}$ A necessidade de análise do histórico de assembleias pode surgir em outras situações. Na sugestão apresentada por Munhoz (2012, p. 357), por exemplo, de que a exceção à presunção de controle proposta por
} 
Como forma de verificar a qualidade das informações prestadas pelas companhias em seus atos societários, realizou-se levantamento das informações constantes nas atas divulgadas para as três últimas Assembleias Gerais Ordinárias, realizadas nos anos de 2011, 2012 e 2013, de cada uma das companhias listadas no Novo Mercado e integrantes do Grupo A (relativamente pulverizadas) .

Para tanto, com base nas respectivas atas divulgadas pelas 28 companhias objeto de análise via IPE, destacaram-se, conforme dados consolidados apresentados no Apêndice F, as seguintes informações: quórum de instalação; realização da assembleia em primeira ou segunda convocação; matérias aprovadas e respectivos quóruns (aprovação de contas sociais, eleição de administradores e remuneração da administração); e, por último, as informações detalhadas sobre os dados anteriores, por exemplo, relação de acionistas presentes e/ou indicação de votos proferidos a favor, contra e abstenções.

Destaca-se, primeiramente, que, em todas as companhias analisadas e respectivas assembleias gerais dos anos de 2011 a 2013, as deliberações sociais se deram em primeira convocação, o que nos induz à ideia de que existe, de fato, uma minoria acionária atuante em tais companhias.

No entanto, nota-se que não há certo padrão na qualidade de informações divulgadas pelas companhias objeto de análise que nos permita correlacionar o exercício do poder de controle entre tais companhias. Ressalta-se que 19 das 28 companhias integrantes do Grupo A disponibilizaram em seus atos societários apenas a relação dos acionistas presentes na reunião, citando-os nominalmente, mas sem divulgar, contudo, qualquer detalhe sobre os votos de cada um, tampouco qualquer referência à respectiva participação acionária detida a respeito do grupo de acionistas presentes e/ou suas respectivas participações no capital social.

A ausência das informações citadas acima inviabiliza a possibilidade de qualquer análise acerca da eventual identificação de predominância em tais assembleias, posto que, embora tais companhias tenham divulgado os respectivos quóruns de instalação em suas assembleias, verificou-se, ainda, que, dentre todas as assembleias gerais realizadas pelas 28 companhias analisadas, a maioria (18) foi instalada com quórum superior a 50\% do capital

meio de estabelecimento de percentual fixo de participação acionária e, consequentemente, a exclusão da obrigatoriedade de condução da oferta pública por aquisição de participação relevante se daria quando (i) houvesse acionista com participação acionária superior à participação total do adquirente, ou (ii) "quando o quórum de instalação e o de deliberação verificados nas três últimas assembleias gerais indicarem não ser provável que a participação detida pelo adquirente, após a aquisição, assegurará a ele preponderância na assembleia geral subsequente.”. 
votante, tendo sido indicada nas respectivas atas apenas a lista de acionistas presentes. Nota-se, portanto, clara dificuldade do aplicador do direito em utilizar os instrumentos previstos em lei para a devida identificação de uma minoria detentora do poder de controle nas companhias listadas no Novo Mercado.

Nesse contexto, cita-se, como exemplo, no âmbito das informações divulgadas entre as atas das reuniões realizadas no ano de 2011, que apenas duas companhias (Brasil Brokers Participações S.A. e Brasil Insurance Participações e Administração S.A.) detalharam de forma esclarecedora em suas respectivas atas as informações necessárias para eventual apuração de exercício efetivo do poder de controle, a saber: (i) relação completa de acionistas presentes; (ii) indicação de votos proferidos a favor; (iii) indicação de votos contrários; e (iv) indicação dos acionistas que se abstiveram de votar.

Ora, pela análise das informações apuradas (Apêndice F), apenas no caso das duas companhias citadas acima, que adotaram como padrão a divulgação de informações detalhadas sobre os votos proferidos em suas respectivas reuniões, foi possível observar com maior clareza se acionista, ou grupo de acionistas, detentor em conjunto de menos do que $50 \%$ do capital social total e votante, tem participação relevante por meio da qual exerça efetivamente o poder de controle sobre as atividades da companhia, inclusive, ao se considerar que em ambas as companhias (com relação às reuniões realizadas em 2011) foram proferidos votos dissidentes, restando clara a prevalência da vontade da maioria da assembleia geral.

Entende-se, portanto, que o detalhado nível de informações apresentadas por essas companhias representa rol de dados que deveria ser adotado como padrão por toda e qualquer companhia listada no Novo Mercado, independentemente de sua estrutura de propriedade acionária ser concentrada ou dispersa. Sendo a assembleia órgão vital da companhia, por meio da qual todas as principais tomadas de decisão sobre a condução dos negócios sociais se tornam legítimas, considera-se que a devida divulgação de seu histórico ao mercado em geral se faz de extrema necessidade.

Assim como foram padronizadas as informações divulgadas pelas companhias, por meio da criação dos Formulários de Referência e Cadastral, quando da edição da ICVM 480, defende-se, aqui, a existência de um detalhamento padronizado das informações divulgadas pelas companhias quando da realização de suas respectivas assembleias gerais, no caso, o percentual do capital social presente à reunião para a sua instalação e os votos proferidos por acionista, com a indicação de votos favoráveis, contrários e abstenções. 


\section{CAPÍTULO 5}

\section{SÍNTESE CONCLUSIVA}

A análise da estrutura da propriedade acionária das companhias brasileiras listadas no Novo Mercado, à luz das estruturas identificadas em países referência, demonstra a importância de certa dinamicidade quando da adoção de padrões de governança e imposição de regras de Direito Societário e de mercado de capitais, com base em uma estrutura de propriedade acionária diluída (como pretendem os otimistas que acreditam na migração completa do sistema brasileiro para referida estrutura), ou mesmo concentrada (como podem defender os mais conservadores que ainda possam relutar na completa migração do sistema brasileiro).

Conforme demonstrado durante o curso da presente dissertação, a dispersão da propriedade acionária é fenômeno ainda recente no Brasil, cujos efeitos, muito embora já possam ser observados na realidade das companhias abertas listadas no Novo Mercado, não são conhecidos por completo. Deve-se reconhecer o fato de que ainda são incertas as previsões sobre o verdadeiro potencial desse fenômeno a longo prazo.

Sabe que o Brasil ainda vive momento único de otimismo econômico e melhor colocação na economia internacional; no entanto, é preciso haver parcimônia e atentar ao fato que ainda é país jovem, que acaba de ingressar em sua fase adulta. Cabe, portanto, aos operadores do Direito em geral esforçarem-se para acompanhar as mudanças pelas quais o País passa, porém sem se desprenderem da cultura intrínseca aos brasileiros. A imposição de institutos do Direito Comparado, como a velha acepção de que o que é produzido no exterior tende a ser superior ao produzido internamente, não é mais cabível.

Sem dúvida, é permitido e aconselhável inspirar-se no Direito Comparado; todavia, deve-se iniciar e consolidar caminho próprio que atenda as particularidades do Brasil, conferindo a segurança jurídica necessária para que o mercado de capitais e a própria economia do País se consolidem em pilares firmes e sólidos.

Sobre a segurança jurídica tão almejada e o papel do Direito no desenvolvimento das companhias e do mercado de capitais no qual elas se inserem, destaca Munhoz (2009, p. 131): 
[...] são muitos os fatores a influenciar a eficiência das companhias. Assim, uma eventual estrutura de controle menos eficiente pode ser compensada por outros fatores, como uma legislação trabalhista mais adequada, incentivos fiscais ou mesmo a detenção de tecnologias mais desenvolvidas, capazes de tornar a companhia tão ou mais eficiente que outras com estruturas de controle mais avançadas.

Nesse contexto, a identificação da realidade e das características particulares do mercado de capitais brasileiro foi fundamental para o bom desenvolvimento do presente estudo. Por meio da pesquisa empírica realizada, comprovou-se que as companhias brasileiras do Novo Mercado habitam um cenário de contraste, no qual, embora tudo pareça favorável à dispersão acionária, ainda há relutância por parte dos acionistas para se manterem titulares do poder de comando sobre as atividades sociais.

Mesmo que existam companhias cujas ações se encontrem extremamente dispersas no mercado e nas quais a condução das atividades sociais resulte sob o domínio da administração, a cultura pela manutenção do poder de controle se mostra arraigada à realidade das companhias brasileiras. Dessa forma, é preciso resgatar a dinamicidade do próprio Direito Comercial, que se constrói em resposta às demandas da economia social.

Uma vez reconhecida essa realidade contrastante das companhias listadas no Novo Mercado, é preciso admitir que o Direito Comercial deve ser forte o suficiente para permitir que elementos econômicos e culturais possam destacar-se na definição do modelo de propriedade acionária mais eficiente, permitindo-se um ponto de equilíbrio entre a estrutura de dispersão acionária identificada em outras nações e a original estrutura de propriedade do capital extremamente concentrada.

Nota-se, hoje, uma zona cinzenta que abrange a dificuldade de distinguir determinadas companhias com base na estrutura da propriedade do capital e, consequentemente, o acionista controlador minoritário do acionista simplesmente ativista, participante das assembleias gerais das companhias investidas. Destacou-se, portanto, a importância de haver uma subdivisão entre as companhias listadas no Novo Mercado com base nos respectivos graus de dispersão, segregando-se, inicialmente, aquelas com acionista controlador majoritário das demais e, em seguida, as sem controlador majoritário de acordo com a presença ou não de acionista (ou grupo de acionistas) detentor do poder 
de controle, ainda que titulares de minoria do capital social votante, segregando-se, portanto, companhias com realidade organizacional completamente diversas ${ }^{68}$.

Ainda na fase de identificação da realidade das companhias brasileiras listadas no Novo Mercado, a pesquisa desenvolvida apresentou estudo empírico desenvolvido em diferentes etapas, com o objetivo de demonstrar a existência do controle minoritário nas companhias listadas no Novo Mercado, bem como analisar o perfil dessas companhias em busca de detalhes que permitissem a construção de um padrão de características essenciais das companhias sob comando do controle minoritário.

Em resposta, confirmou-se a suspeita de presença, entre as companhias do Novo Mercado, de uma minoria do capital social com grande influência na condução dos negócios sociais, em mesmo grau daquelas exercidas por acionistas detentores do controle majoritário interno, sendo, portanto, reconhecida pela própria companhia em questão a existência de uma "minoria" sob o comando das atividades sociais.

Quanto ao desenho de padrão que pudesse permitir clara classificação das companhias nas quais essa minoria influente encontrava-se no comando, verificou-se grande diversidade em todas as companhias listadas no Novo Mercado e também entre as classificadas como de propriedade acionária relativamente pulverizadas.

A título de exemplo, observou-se que o maior acionista das companhias listadas no Novo Mercado possui participação média de 34,16\%. No entanto, essa amostra abrange tanto companhias controladas por acionista ou grupo de acionistas detentores de participação societária majoritária $(51,94 \%)$, com média de participação conjunta majoritária e controladora aproximada de $60 \%$ do capital social, como companhias nas quais um acionista ou grupo de acionistas titulares de menos da metade do capital social detém média de participação conjunta controladora e não majoritária correspondente a $32,06 \%$ do capital social.

\footnotetext{
${ }^{68}$ Deve-se reconhecer o controle minoritário como tendência já presente entre grandes companhias brasileiras e reconhecida pelo mercado. Em depoimento prestado por Jean Marc Etli, à Revista EXAME, sobre tendências para as próximas décadas, declarou o então CEO do Banco Itaú BBA com relação à propriedade acionária: "Os empresários percebem cada vez mais que não precisam dos 51\% para manter o controle. Quando falamos de controle, nos referimos a duas coisas: uma é a gestão; outra, o processo de alienação da companhia. Mesmo com $30 \%$ das ações o empresário possui de fato a gestão. [...] Por isso, acredito que vamos evoluir da figura do controlador para a do acionista de referência, como, aliás, foi o caminho percorrido pelos mercados desenvolvidos." Disponível em: Revista Capital Aberto, set. 2013, p. 41.
} 
De tal sorte, resgata-se que o universo de 129 companhias abertas listadas no Novo Mercado foi classificado da seguinte forma: 95 companhias $(73,64 \%)$ com controle societário definido, das quais $67(51,94 \%)$ classificadas com propriedade acionária concentrada, estão sob controle majoritário, e 28 (21,71\%), classificadas com propriedade acionária relativamente pulverizada, encontram-se sob a influência de controle não majoritário, restando apenas 34 (26,36\%) com estrutura acionária pulverizada, ou seja, sem controle definido.

A comparação da média final de ações em circulação verificada nas companhias integrantes dos Grupos A (com propriedade acionária relativamente pulverizada, controladas, portanto por minoria do capital social) e B (com propriedade acionária pulverizada, sem controle definido), $61,26 \%$ e $94,59 \%$ respectivamente, evidenciou a grande diversidade existente entre as companhias listadas no Novo Mercado, em especial a diferenciação que se faz necessária entre companhias listadas sem controle majoritário.

Ainda em busca de determinado padrão em meio à tamanha variedade de companhias, procedeu-se à análise dos acordos de acionistas celebrados por acionistas controladores das companhias classificadas no Grupo A, tendo sido constatado que, em dez companhias $(35,71 \%$ do total do Grupo A, $16,67 \%$ das companhias sem controle majoritário, e 7,75\% das companhias listadas no Novo Mercado), os acordos celebrados versavam sobre forte influência controladora.

Na mesma linha, foram analisados os estatutos sociais das 20 companhias do Grupo B, que divulgaram a existência de acordos de acionistas arquivados em suas sedes sociais, tendo sido verificado que 15 companhias adotaram a estrutura das pílulas de veneno tropicalizadas, das quais 11 apresentaram em seu mecanismo exceção de obrigatoriedade de realização da OPA para as participações relevantes que fossem detidas e/ou acumuladas antes do registro da companhia junto à CVM. Dentre as 11 companhias citadas, 9 delas apresentaram percentual de gatilho inferior ao de participação detido pelo bloco de controle, mas não necessariamente eram as mesmas companhias nas quais os acordos de acionistas celebrados correspondiam a acordos de comando.

Nesse contexto, diante da total diversidade entre as companhias integrantes do Novo Mercado, em especial aquelas classificadas no Grupo A, bem como das questões identificadas na prática societária que resultaram em relevantes reflexões sobre o tema pela própria CVM, foram analisados os aspectos jurídicos do instituto do controle societário 
interno de forma a averiguar o reconhecimento dessa realidade pelo ordenamento jurídico brasileiro.

A partir do reconhecimento (i) do instituto do controle societário interno como realidade de fato e não de direito, na qual o acionista controlador comanda as atividades sociais e a estrutura e negócios da administração da companhia, por meio da prevalência de suas decisões na assembleia geral; (ii) da interpretação restritiva do disposto no artigo 116, alínea "b", da Lei das S.A., assumindo-se a presunção de controle prevista no referido dispositivo pelo acionista detentor da maioria do capital social, com possibilidade de exclusão de tal responsabilidade mediante prova em contrário; e (iii) da definição de poder de controle apresentada pelo Regulamento de Listagem do Novo Mercado, que possui previsão que reconhece claramente a possibilidade de configuração do controle minoritário em companhias listadas no Novo Mercado, restou confirmada a adoção do instituto do controle minoritário interno pelo ordenamento jurídico brasileiro.

Não obstante, confirmadas a amplitude dos conceitos trazidos pelo ordenamento jurídico-societário e a consequente abrangência do instituto do controle societário interno pelo referido sistema, concluiu-se que o principal desafio do Direito Societário, no âmbito da propriedade acionária brasileira e do controle minoritário presente em companhias listadas no Novo Mercado, encontra-se na dificuldade prática de identificação do acionista controlador para efeito das responsabilidades e dos deveres cabíveis a esse acionista, nos termos previstos na Lei das S.A.

Considerando que a configuração do acionista controlador minoritário está pautada na comprovação do uso efetivo do poder de controle, ressalta-se a importância de utilização de critérios objetivos que proporcionem maior eficiência e segurança a tal apuração. No entanto, dada ausência de um padrão entre as companhias classificadas no Grupo A, notou-se que os critérios de grau de dispersão acionária, existência de acordos de comando e/ou de cláusulas de pílulas de veneno tropicalizadas, mostraram-se apenas como indícios de presença de acionista ou grupo de acionistas que, na maioria dos casos, se utiliza desses artifícios como instrumentos de entrincheiramento e manutenção do poder de controle, mostrando-se, sob uma visão conservadora, como insuficientes para a determinação objetiva de um acionista ou grupo de acionistas titulares de participação inferior à maioria do capital votante, como detentores do poder de comando.

Nesse contexto, resgatando-se o próprio mecanismo apresentado pelo regulamento do Novo Mercado de confirmação do uso efetivo do poder de controle por meio da 
constatação de preponderância nas três últimas assembleias gerais da companhia, destacouse a insuficiência de aplicabilidade desse critério, com base apenas nas informações divulgadas atualmente pelas companhias listadas no Novo Mercado.

Considerando-se inclusive que o controle societário minoritário se fortalece diante do absenteísmo dos demais acionistas, recomenda-se maior exigência por parte das autoridades reguladoras do mercado de capitais no que se refere ao nível de informações divulgadas pelas companhias abertas, em especial as listadas no Novo Mercado. De tal sorte, seguindo-se a padronização de informações divulgadas ao mercado, quando da criação dos Formulários de Referência e Cadastral, conclui-se pela necessidade de detalhamento padronizado das informações divulgadas pelas companhias na ocasião da realização de suas respectivas assembleias gerais, devendo ser indicado, para tanto, o percentual específico do capital social que instalou a instalação e os votos proferidos por acionista, com a indicação de votos favoráveis, contrários e abstenções.

Acredita-se que essa medida traria mais ferramentas para a identificação do acionista controlador minoritário, conferindo maior confiabilidade por parte da doutrina quanto à sua existência e dos próprios operadores do mercado em geral com relação ao exercício de seus direitos, no âmbito dos deveres e obrigações atribuídos aos acionistas controladores pelo ordenamento jurídico-societário.

Desse modo, espera-se que a comprovação empírica da existência do controle minoritário entre as companhias abertas brasileiras listadas no Novo Mercado, bem como o reconhecimento de sua existência pelo ordenamento jurídico brasileiro, tenham destacado a devida importância ao instituto do controle minoritário que integra a realidade das companhias brasileiras, demandando o bom entendimento sobre o tema por parte dos operadores do Direito Societário e de mercado de capitais, de modo a conferir a justa eficácia das consequências dessa constatação para efeito do disposto nos artigos 116 e 117 da Lei das S.A. 


\section{REFERÊNCIAS}

APPENDINO, Fábio; DE OLIVEIRA, Luis Gustavo Miranda; e MARUCH, André. Aquisição de controle em companhias com capital pulverizado ou com controle minoritário: uma análise da legislação e de casos. In: BOTREL, Sérgio (Coord.). Direito societário: análise crítica. São Paulo: Saraiva, 2012. 434 p.

ARNOLDI, Paulo Roberto Colombo; MICHELAN, Taís Cristina de Camargo. Novos enfoques da função social da empresa numa economia globalizada. Revista de Direito Mercantil, Industrial, Econômico e Financeiro. São Paulo: Malheiros, jan./mar. 2000. v. 117, p. 157-162.

ASCARELLI, Tullio. Problemas das sociedades anônimas e direito comparado. Rio de Janeiro: Quorum Editora, 2001. 755 p.

Panorama do direito comercial. Sorocaba: Minelli, 2005. 154 p.

AZEVEDO, Luís André N. M. Ativismo dos investidores institucionais e poder de controle nas companhias abertas de capital pulverizado brasileiras. In: CASTRO, Rodrigo R. Monteiro de; AZEVEDO, Luís André N. de Moura (Coord.). Poder de controle e outros temas de direito societário e mercado de capitais. São Paulo: Quartier Latin, outono de 2010. pp. 217-262.

BEBCHUK, Lucian A.; ROE, Mark J. A Theory of Path Dependence in Corporate Governance and Ownership, p. 37. Stanford Law Review, v. 52, p. 127-170, 1999; Columbia Law School, Center for Studies in Law \& Economics Paper, n. 131, Nov. 1999. Disponível em: <http://papers.ssrn.com/paper.taf?abstract_id=192414>. Acesso em: 20 jun. 2012.

; KRAAKMAN, Reinier H.; e TRIANTIS, George G. Stock pyramids, crossownership, and the dual class equity: the creation and agency costs of separating control from cash flow rights (Feb. 1999). NBER Working Paper Series, v. 6951, pp. -, 1999; Harvard Law School Olin Discussion Paper, n. 249, 1999. Disponível em: $<$ http://papers.ssrn.com/sol3/papers.cfm?abstract_id=147590>. Acesso em: 22 jun. 2012.

BECHT, Marco. Reciprocity in Takeovers. European Corporate Governance Institute (ECGI). Law Working Paper, n. 14/2003, Oct. 2003. Disponível em <http://papers.ssrn.com/sol3/papers.cfm?abstract_id=463003>. Acesso em: 20 jan. 2014. 
BERLE, Adolph A.; MEANS, Gardiner C. The Modern Corporation \& Private Property. Originally published in 1968. Eleventh Printing 2012. Transaction Publishers: New Brunswick, New Jersey.

BERTOLDI, Marcelo M. O poder de controle na sociedade anônima: alguns aspectos. Revista de Direito Mercantil, Industrial, Econômico e Financeiro. São Paulo: Malheiros, v. 118, p. 62-76, abr./jun. 2000.

Acordo de acionistas. São Paulo: Editora Revista dos Tribunais, 2006. 237 p.

BIANA, Higor da S. Leading Case CVM: o caso TIM. Relatório anual de pesquisa. Orientação: Norma Jonssen Parente. PUC-RJ, Departamento de Direito, 2011. Disponível em: <http://www.puc-rio.br/pibic/relatorio_resumo2011/Relatorios/CSS/DIR/DIR_Higor_ Biana.pdf >. Acesso em: 15 dez. 2013.

BLACK, Bernard S., CARVALHO, Antonio G. de; e GORGA, Érica. The Corporate Governance of Privately Controlled Brazilian Firms. Revista Brasileira de Finanças, v. 7, 2009. Disponível em: <http://papers.ssrn.com/sol3/papers.cfm?abstrac t_id=1528183>. Acesso em: 22 jun. 2012.

BOCATER, Maria Isabel do Prado. Poder de controle e influência significativa. In: KUYVEN, Luiz Fernando Martins. Temas essenciais de direito empresarial: estudos em homenagem a Modesto Carvalhosa. São Paulo: Saraiva, 2012. p. 833-845.

BORBA, José Edwaldo Tavares. Direito societário. 12. ed. Rio de Janeiro: Renovar, 2009.

BORGES, Leandro V.; BERNARDES, Lucas P.; COMETTI, Marcelo T. E;

NAKAYAMA, Wilson. A poison pill brasileira: proteção da dispersão acionária ou reforço do poder de controle?. Revista de Direito Mercantil, Industrial, Econômico e Financeiro, São Paulo, v.159/160, p. 231-244, jul./dez. 2011.

CARVALHO, Antonio Gledson de. A governança corporativa no Brasil em perspectiva. Revista de Administração, São Paulo, v. 37, n. 3, p. 19-32, jul./set. 2002.

CARVALHO, Antonio Gledson de. Efeitos da migração para os níveis de governança da Bovespa, jan. 2003. Disponível em:

<http://www.ibmec.org.br/pub/projetos/p00060100.pdf>. Acesso em: 26 fev. 2012. 
CARVALHOSA, Modesto. A dispersão acionária e o desaparecimento da figura do controlador. In: ROVAI, Luiz Armando; MURRAY NETO, Alberto (Coord.). As sociedades por ações na visão prática do advogado. Rio de Janeiro: Elsevier, 2010. 243 p.

A nova lei das S/A. São Paulo: Saraiva, 2002.

Acordo de acionistas: homenagem a Celso Barbi Filho. São Paulo: Saraiva, 2011a. 420 p.

Pulverização do controle acionário no Brasil. $8^{\circ}$ Seminário ANBIMA de Direito do Mercado de Capitais. São Paulo, 23 ago. 2011b. Disponível em: < http://www.anbima.com.br/eventos/arqs/eventos_anteriores/8-

direito_mercado/modesto_carvalhosa.pdf >. Acesso em: 16 jun. 2012.

Comentários à Lei de Sociedades Anônimas: Lei n. ${ }^{\circ}$ 6.404, de 15 de dezembro de 1976, com modificações das Leis n. ${ }^{\circ} 9.475$, de 5 de maio de 1997, e n. ${ }^{\circ} 10.303$ de 31 de outubro de 2001. São Paulo: Saraiva, 2003. v. 2, 3 e 4 - tomo II.

CASO TIM. Processo Administrativo CVM n. ${ }^{\circ}$ RJ 2009/1956. Disponível em: $<$ http://www.cvm.gov.br/port/descol/resp.asp?File=2009-026ED15072009.htm>. Acesso em: 10 fev. 2012.

CHEFFINS, Brian R., Putting Britain in the Roe map: the mergence of the Berle-Means corporation in the United Kingdom. University of Cambridge - Faculty of Law; European Corporate Governance Institute (ECGI), Feb. 2000. Disponível em: $<$ http://papers.ssrn.com/sol3/papers.cfm?abstract_id=218655>. Acesso em 10 set. 2013.

COFFEE JR., John C. The rise of dispersed ownership: the role of Law in the separation of ownership and control. The Center for Law and Economic Studies Working Paper, New York, n. 182, Jan. 2001. Disponível em:

<http://papers.ssrn.com/sol3/papers.cfm?abstract_id=254097>. Acesso em: 16 jun. 2012.

COMPARATO, Fábio Konder; SALOMÃO FILHO, Calixto. O poder de controle na sociedade anônima. 4. ed. Rio de Janeiro: Forense, 2005. 595 p.

CONSELHEIROS da HRT fazem queixa à CVM. Jornal Valor Econômico, 2 jan. 2014. Disponível em: <http://www.valor.com.br/empresas/3382906/conselheiros-da-hrt-fazemqueixa-cvm\#ixzz2pEZoHj7g>. Acesso em: jan. 2014. 
DA SILVA, Thiago José. Reflexões sobre a aplicação de Leis estrangeiras pela CVM. In: PENTEADO, Mauro Rodrigues; MUNHOZ, Eduardo Secchi. Mercado de capitais brasileiro: doutrina, cases e material. São Paulo: Quartier Latin, 2012. p. 333-347.

DICK, I. J. Alexander e ZINGALES, Luigi. Private benefits of control: an international comparison. CRSP Working Paper, n. 535; Harvard PON Working Paper; AFA 2003. Washington, DC Meetings. Disponível em: <http://papers.ssrn.com/sol 3/papers.cfm?abstract_id=296107>. Acesso em: 10 jun. 2012.

EASTERBROOK, Frank H.; FISCHEL, Daniel R. The economic Structure of Corporate Law. Cambridge, Massachussetts, London, England: Harvard University Press, 1991, 370 p.

EIZIRIK, Nelson. Mercado de capitais: regime jurídico. Rio de Janeiro: Renovar, 2008. 636 p. 2. ed. // 2011, 3. ed., 660 p.

Propriedade e controle na companhia aberta - uma análise teórica. Revista de Direito Mercantil, Industrial, Econômico e Financeiro. São Paulo: Malheiros, v. 54, pp. 90-104, abr./jun. 1984.

Aquisição de controle minoritário. Inexigibilidade de oferta pública. In: CASTRO, Rodrigo R. Monteiro de; AZEVEDO, Luís André N. de Moura (Coord.). Poder de controle e outros temas de direito societário e mercado de capitais. São Paulo: Quartier Latin, 2010. pp. 177-190.

O mito do "Controle Gerencial" - Alguns dados empíricos. Revista de Direito Mercantil, Industrial, Econômico e Financeiro. São Paulo: Malheiros, v. 66, pp. 103106, abr./jun. 1987.

ETCHEVERRY, Raul Aníbal. Intereses societarios y extra societarios en la administración de las sociedades anónimas. Revista de Direito Mercantil, Industrial, Econômico e Financeiro. São Paulo: Malheiros, v. 55, pp.18-34, jul./set. 1984.

FIGUEIRAS, Maria Luíza. Para Nelson Tanure, quanto pior, melhor. Revista EXAME, 31 jan. 2014. Disponível em: <http://exame.abril.com.br/revistaexame/edicoes/1058/noticias/quanto-pior-melhor-2>. Acesso em: jan. 2014

FRONTINI, P. S. Função social da companhia: limitações ao poder de controle. In: ADAMEK, Marcelo Vieira Von (Coord.). Temas de direito societário e empresarial contemporâneos. São Paulo: Malheiros, 2011. pp. 535-551. 
FUNDADOR quer adiar assembleia da HRT para ganhar tempo. Jornal Valor Econômico, 3 jan. 2014. Disponível em:

$<$ http://www.valor.com.br/empresas/3383956/fundador-quer-adiar-assembleia-da-hrt-paraganhar-tempo\#ixzz2pKgIRzNQ>. Acesso em: jan. 2014.

GARCIA, Letícia Simonetti. O controle nas companhias abertas brasileiras de capital pulverizado. Tese (Doutorado em Direito Comercial) - Faculdade de Direito, Pontifícia Universidade Católica de São Paulo: São Paulo, 2008.

GILSON, Ronald J. Controlling Shareholders and corporate governance: complicating the comparative taxonomy. Harvard Law Review, v. 119, pp.1641-1679, Apr. 2006.

; GORDON, Jeffrey N. Controlling shareholders. Stanford Law School, Working Paper, n. 309; Columbia Law School, Working Paper, n. 281, jun. 2003. Disponível em: <http://papers.ssrn.com/sol3/papers.cfm?abstract_id=417181>. Acesso em: 15 jun. 2012.

GORGA, Érica. Direito societário atual. Rio de Janeiro: Elsevier, 2013. 300 p.

Changing the paradigm of stock ownership: from concentrated towards dispersed ownership? Evidence from Brazil and consequences for emerging countries. American Law \& Economics Annual $18^{\text {th }}$ Association Meeting. Cornell Law Faculty Working Papers. Paper 42, 2008. Disponível em: <http://scholarship.law.cornell.edu/clso ps_papers/42/>. Acesso em: 15 jun. 2012.

GUERREIRO, José Alexandre Tavares. Sociologia do poder na Sociedade Anônima. Revista de Direito Mercantil, Industrial, Econômico e Financeiro. São Paulo: Malheiros, v. 77, pp. 50-56, jan./mar. 1990.

Sociedade Anônima: poder e dominação. Revista de Direito Mercantil, Industrial, Econômico e Financeiro. São Paulo: Malheiros, v. 53, p. 78, jan./mar. 1984.

. Sociedade Anônima. Reorganização Societária. Alienação de ações. Alienação de controle direta e indireta: Inaplicabilidade do artigo 254-A da Lei das Sociedades Anônimas. Revista de Direito Bancário e do Mercado de Capitais, v. 12, p. 207-224, 2009.

GUERREIRO, José Alexandre Tavares; TEIXEIRA, Egberto Lacerda. Das sociedades anônimas no direito brasileiro. São Paulo: José Bushatsky, 1979. 442 p. v. 1 e 2. 
HERMAN, Edward S. Corporate control, corporate power: a twentieth century fund study. Cambridge University Press. Binhamton, New York: 1981.

HANSMANN, Henry. The ownership of enterprise. Cambridge: Harvard University Press, 2000.

JÁNSZKY, André. A poison pill norte-americana e sua adoção em outros países. Seminário Instituto Brasileiro de Governança Corporativa (IBGC), 17 nov. 2008, sede da BM\&FBOVESPA. Disponível em: <http://www.ibgc.org.br>. Acesso em: 11 nov. 2013.

JOSÉ COSTA, Vamilson. O princípio majoritário na formação da vontade social das sociedades anônimas e o estabelecimento do poder de controle estável. In: WALD, Arnoldo; FONSECA, Rodrigo Garcia da. A empresa no terceiro milênio: aspectos jurídicos. São Paulo: Juares de Oliveira, 2005. pp. 93-104.

KRAAKMAN, Reinier R.; DAVIES, Paul; HANSMANN, Henry; HERTIG, Gerard; HOPT, Klaus J.; KANDA, Hideki; ROCK, Edward B. The Anatomy of Corporate Law: a comparative and functional approach. 3. ed. New York: Oxford University Press, 2006. $231 \mathrm{p}$.

LA PORTA, Rafael; LOPEZ-DE-SILANES, Florêncio; SHLEIFER, Andrei. Corporate Ownership around the world. Harvard University, Aug. 1998. Paper n. 1840. Disponível em: <http://papers.ssrn.com/sol3/papers.cfm?abstract_id=103130>. Acesso em: 20 jun. 2012.

LAMY FILHO, Alfredo. Temas de S.A. Rio de Janeiro: Renovar, 2007. 450 p.

; BULHÕES PEDREIRA, José Luiz. A Lei das S.A. Rio de Janeiro: Renovar, 1997, 1996. v. 1 e 2.

LEÃES, Luiz Gastão Paes de Barros. Comentários à lei das Sociedades Anônimas: artigos 52 a 120 (Coord. Arnoldo Wald). São Paulo: Saraiva, 1980. 281 p. v. 2.

LEAL, Ricardo Pereira Câmara; SAITO, Richard. Finanças Corporativas no Brasil. RAE Eletrônica, v. 2, n. 2, jul./dez. 2003. São Paulo: Fundação Getúlio Vargas - Escola de Administração de Empresas de São Paulo. Disponível em: 
$<$ http://www.rae.com.br/eletronica/index.cfm?FuseAction=Artigo\&ID=1469\&Secao=FIN ANÇAS\&Volume $=2 \&$ Numero=2\&Ano=2003 $>$. Acesso em: 15 junho 2012.

LEECH, Dennis. Minority control: an analysis of British companies using voting power indices. Mar., 1999. Warwick Economic Research Paper Number 529. University of Warwick, United Kingdom, Department of Economics. Disponível em: <http://wrap.warwick.ac.uk/1649/>. Acesso em: 12 maio 2012.

LEITE, Leonardo Barém. A Lei das Sociedades Anônimas, 30 anos depois: uma breve análise da evolução da legislação e da realidade do mercado brasileiro, chegando-se ao momento atual, em tempos de Governança Corporativa, "IPOs" e "Sarbanes-Oxley Act". In: CASTRO, Rodrigo R. Monteiro; ARAGÃO, Leandro Santos de (Coord.). Sociedade Anônima: 30 anos da Lei 6.404/76. São Paulo: Quartier Latin, 2007.

LOBO, Carlos Augusto da Silveira. Reflexões sobre a responsabilidade do acionista controlador. Revista de Direito Renovar. Rio de Janeiro: Renovar, v. 12, pp. 41-53, set./dez.1998.

LUCENA, José Waldecy. Das Sociedades Anônimas, comentários à lei. Rio de Janeiro: Renovar, 2009. v. 1.

MACEDO, Ricardo Ferreira de. Controle não societário. Rio de Janeiro: Renovar, 2004.

. Limites de efetividade do direito societário na repressão ao uso disfuncional do poder de controle nas sociedades anônimas. Revista de Direito Mercantil, Industrial, Econômico e Financeiro. São Paulo: Malheiros, Abr./Jun.2000. v.118, pp.167-218.

MAIDA, Silvia M. P. Acionista controlador: alienação do controle e incorporação de sociedades: responsabilidade nas operações em desacordo com as normas do contrato e da lei. Revista de Direito Mercantil, Industrial, Econômico e Financeiro. São Paulo: Malheiros, v. 113, pp. 210-221, jan./mar. 1999.

MANNE, Henry G. Mergers and the Market for Corporate Control. The Journal of Political Economy, vol. 73, No. 2 (Apr., 1965), pp. 110-120. Disponível em $<$ http://links.jstor.org/sici?=0022-3808\%28196504\%2973\%3A2\%3C110\%3AMATMFC \%3E2.0.CO\%3B2-3 > Acesso em 20 abr. 2011.

MARTES, Camilla Ribeiro; YOSHINAGA, Esther Seiko; LONGHI, Maria Isabel C. Sica A alienação do controle minoritário. In: PENTEADO, Mauro Rodrigues; MUNHOZ, Eduardo Secchi. Mercado de capitais brasileiro: doutrina, cases e material. São Paulo: Quartier Latin, 2012. p. 31-52. 
MARTINS NETO, Carlos. Dispersão acionária, tomada hostil de controle e poison pills: breves reflexões. Revista Semestral de Direito Empresarial. Departamento de Direito Comercial e do Trabalho da Faculdade de Direito da Universidade do Estado do Rio de Janeiro. Rio de Janeiro: Renovar, jul./dez. 2009.

MB ASSOCIADOS. Desafios e Oportunidades para o Mercado de Capitais Brasileiro, in Estudos para o Desenvolvimento do Mercado de Capitais. Bolsa de Valores de São Paulo, equipe técnica: José Roberto Mendonça de Barros; José Alexandre Scheinkman; Luiz Leonardo Cantidiano; Lídia Goldenstein; Tereza Maria Fernandez Dias da Silva; Antonio Gledson de Carvalho. São Paulo: Bolsa de Valores de São Paulo - BOVESPA, jul., 2000.

MORAES, Luiza Rangel de. A pulverização do controle de companhias abertas. Revista de Direito Bancário e do Mercado de Capitais. São Paulo: Revista dos Tribunais, v. 32, pp. 49-84, abr./jun. 2006.

MOTTA, Nelson Candido. Alienação e titularidade do poder de controle nas companhias abertas: notas sobre a transferência de ações entre participantes do grupo controlador e sobre a interpretação do art. 254 da Lei das S.A. Revista Forense. Rio de Janeiro, Forense, v. 324, pp. 81-87, out./nov./dez. 1993.

MUNHOZ, Eduardo Secchi. Aquisição de controle na sociedade anônima. São Paulo: Saraiva, 2013. 413 p.

Desafios do direito societário brasileiro na disciplina da companhia aberta: avaliação dos sistemas de controle diluído e concentrado. In: CASTRO, Rodrigo R. Monteiro de; ARAGÃO, Leandro Santos de (Coord.). Direito societário: desafios atuais. São Paulo: Quartier Latin, verão de 2009. 417 p.

. Transferência de Controle nas Companhias sem Controlador Majoritário. In: CASTRO, Rodrigo R. Monteiro de; AZEVEDO, Luís André N. de Moura (Coord.). Poder de controle e outros temas de direito societário e mercado de capitais. São Paulo: Quartier Latin, outono de 2010, pp. 285-324.

MUNIZ, Joaquim de Paiva. Poder de controle, conflito de interesses e proteção aos minoritários e stakeholders. Revista de Direito Bancário e do Mercado de Capitais. São Paulo: Revista dos Tribunais, v. 8, pp.70-94, abr./jun., 2005.

OIOLI, Erik Frederico. Obrigatoriedade do tag along na aquisição de controle diluído. In: ADAMEK, Marcelo Vieira von. Temas de direito societário e empresarial contemporâneos. São Paulo: Malheiros, 2011. p. 316-326. 
PARENTE, Norma Jonssen. A Lei de Sociedades Anônimas sob ótica dos princípios constitucionais. Revista de Direito Mercantil, Industrial, Econômico e Financeiro. São Paulo: Malheiros, v. 134, pp.72-76, abr./jun. 2004.

PELA, Juliana Krueger. As golden shares no direito societário brasileiro. São Paulo: Quartier Latin, 2012. 227 p.

PELLINI, Patrícia Bolina. Dispersão do capital das companhias abertas brasileiras e medidas estatutárias voluntárias de defesa. 2008. Dissertação (Mestrado em Direito Comercial) - Faculdade de Direito, Pontifícia Universidade Católica de São Paulo, São Paulo, 2008.

PENTEADO, Mauro Rodrigues. Apontamentos sobre a alienação do controle de companhias abertas. Revista de Direito Mercantil, Industrial, Econômico e Financeiro. São Paulo: Malheiros, n. 76, pp. 15-25, out./dez. 1989.

PENTEADO, Arthur B. Aspectos jurídicos da estrutura da propriedade acionária das companhias abertas brasileiras. 2005. Dissertação (Mestrado) - Faculdade de Direito da Universidade de São Paulo, São Paulo, 2005. Orientação: Prof. Doutor Luís Gastão Paes de Barros Leães.

PEREIRA, Guilherme Döring C. Alienação do poder de controle acionário. São Paulo: Saraiva, 1995. $301 \mathrm{p}$.

PRADO, Roberta N. Da obrigatoriedade por parte do adquirente do controle de sociedade por ações de capital aberto de fazer simultânea oferta pública, em iguais condições, aos acionistas minoritários - art. 254 da Lei 6404/76 e Resolução CMN 401/76 - é efetivo mecanismo de proteção aos minoritários?. Revista de Direito Mercantil, Industrial, Econômico e Financeiro. São Paulo: Malheiros, v. 106, p. 83-106, abr/jun. 1997.

. Desconcentração do poder de controle e poison pills: evolução no mercado de capitais brasileiro. In: CASTRO, Rodrigo R. Monteiro de; AZEVEDO, Luís André N. de Moura (Coord.). Poder de controle e outros temas de direito societário e mercado de capitais. São Paulo: Quartier Latin, 2010. pp. 376-410.

Oferta pública de ações obrigatória nas S.A: tag along. São Paulo: Quartier Latin, 2005. 366 p.

SALOMÃO FILHO, Calixto. O novo direito societário. 4. ed. São Paulo: Malheiros, 2011. SANTANA, Maria Helena. O novo mercado. In: Focus 5. Novo Mercado and its followers: case studies in corporate governance reform. The World Bank Group, 
2008. Disponível em: <http://www.ifc.org/ifcext/cgf.nsf/AttachmentsByTitle/FOCUS5_Po rtuguese/\$FILE/Focus5_portuguese.pdf>. Acesso em: 10 jun. 2012.

SANTOS, Aline Menezes. Reflexões sobre a governança corporativa no Brasil. Revista de Direito Mercantil, Industrial, Econômico e Financeiro. São Paulo: Malheiros, v. 130, pp. 180-206, abr./jun. 2003.

SCALZILLI, João Pedro; PATELLA, Laura Amaral; AZEVEDO, Luís André N. de Moura; SPINELLI, Luis Felipe; TELLECHEA, Rodrigo. Perspectivas para a disciplina da companhia aberta: principais desafios do direito societário brasileiro. Revista de Direito Mercantil, Industrial, Econômico e Financeiro. São Paulo: Malheiros, v. 158, pp.211241, abr./jun. 2011.

SHLEIFER, Andrei; VISHNY, Robert. Large shareholders and corporate control. Journal of Political Economy, v. 94, pp. 461-488, 1986.

SILVEIRA, Alexandre di Miceli da. Governança corporativa e estrutura de propriedade. São Paulo: Saint Paul, 2006. 256 p.

Governança corporativa: desempenho e valor da empresa no Brasil. São Paulo: Saint Paul, 2006, 182 p.

SIMIONATO, Frederico Augusto Monte. A função social e o controle do poder de controle nas companhias. Revista de Direito Mercantil, Industrial, Econômico e Financeiro. São Paulo: Malheiros, v. 135, pp. 94-109, jul./set. 2004.

TORNOVSKY, Miguel. Acordos de acionistas sobre o exercício do poder de controle análise das principais alterações introduzidas ao art. 118 da Lei das S/A pela Lei 10303/2001. Revista de Direito Mercantil, Industrial, Econômico e Financeiro. São Paulo, v.127, pp.93-106, jul./set.2002.

VALADARES, Silvia Mourthe; LEAL, Ricardo P. C. Ownership and control structure of Brazilian companies. Disponível em: <http://papers.ssrn.com/sol3/papers.cfm?abstract_i $\mathrm{d}=213409$ > . Acesso em: 10 jun. 2012.

VERÇOSA, Haroldo Malheiros D. Curso de direito comercial. São Paulo: Malheiros, 2008. v. 3 (Sociedade por Ações, Sociedade Anônima e Sociedade em Comandita por Ações). p. 266. 


\section{APÊNDICES}

\section{APÊNDICE A}

Tabela 1 - Perfil das Companhias Listadas no Novo Mercado ${ }^{1}$

\begin{tabular}{|c|c|c|c|c|c|c|c|c|c|}
\hline \# & Denominação & $\begin{array}{c}\text { Setor de } \\
\text { Atividade }^{70}\end{array}$ & $\begin{array}{c}\text { Data da } \\
\text { Constituição }^{71} \\
\end{array}$ & $\begin{array}{c}\text { Data do } \\
\text { Registro } \\
\text { CVM }^{72}\end{array}$ & $\begin{array}{c}\text { Data da } \\
\text { Listagem } \\
\mathrm{NM}^{\mathbf{7 3}}\end{array}$ & $\begin{array}{c}\text { Integra } \\
\text { Ibovespa }^{74} \\
\end{array}$ & $\begin{array}{l}\text { Integra } \\
\text { IBrX }^{75}\end{array}$ & $\begin{array}{c}\text { Patrimônio Líquido } \\
\text { Consolidado em } \\
\text { 31/12/2012 } \\
(\mathrm{em} \mathrm{R} \$)^{76}\end{array}$ & $\begin{array}{c}\text { Valor de Mercado } \\
\text { em Dez./2013 } \\
(\mathbf{R} \$)^{77} \\
\end{array}$ \\
\hline 1 & $\begin{array}{l}\text { Aliansce Shopping Centers } \\
\text { S.A. }\end{array}$ & $\begin{array}{l}\text { Construção Civil, Mat. } \\
\text { Constr. e Decoração }\end{array}$ & $22 / 12 / 2003$ & $18 / 1 / 2008$ & $29 / 1 / 2010$ & Não & Não & $1.865 .441 .985,70$ & $\mathrm{n} / \mathrm{d}$ \\
\hline
\end{tabular}

${ }^{69}$ Relação elaborada com base nas companhias listadas no segmento do Novo Mercado, cuja data de listagem tenha ocorrido até 31 de maio de 2013 , conforme dados disponibilizados no Boletim Diário de Informações BM\&FBOVESPA, ed. 157, 19 ago. 2013. Disponível em: <http://www.bmfbovespa.com.br/download/ BOLETINSDIARIOS/boletimdiario_20130819.pdf>. Acesso em: 20 ago. 2013. Relação atualizada de companhias listadas no Novo Mercado disponível em: <http://www.bmfbovespa.com.br/Cias-Listadas/Empresas-Listadas/BuscaEmpresaListada.aspx?idioma=pt-br>. Acesso em: 6 jul. 2013.

${ }^{70}$ Dados apresentados conforme informações disponibilizadas pelas companhias objeto da análise, no Capítulo Dados Cadastrais, da última versão de seus respectivos Formulários Cadastrais, divulgados até 31 de maio de 2013. Informações disponíveis em: <http://www.cvm.gov.br>. Acesso em: ago. 2013.

${ }^{71}$ Ibidem.

${ }^{72}$ Ibidem.

73 Informações divulgadas em Diário de Informações BM\&FBOVESPA, ed. 157, 19 ago. 2013. Disponível em <http://www.bmfbovespa.com.br/download/BOLE TINSDIARIOS/boletimdiario_20130819.pdf>. Acesso em: 20 ago. 2013.

${ }^{74}$ Composição do Ibovespa apresentada com base em carteira teórica do índice válida para o quadrimestre de janeiro a abril de 2014 , composta por 72 companhias, conforme divulgado pela BM\&FBOVESPA. Disponível em: <http://www.bmfbovespa.com.br/indices/ResumoCarteiraQuadrimestre.aspx?Indice=Ibovespa\&idioma=pt-br>. Acesso em: 6 jan. 2014.

${ }_{75}$ Composição do IBRX apresentada com base em carteira teórica do índice válida para o quadrimestre de janeiro a abril de 2014, composta por cem companhias, conforme divulgado pela BM\&FBOVESPA. Disponível em: <http://www.bmfbovespa.com.br/indices/ResumoCarteiraTeorica.aspx?Indice=IBrX\&idioma=pt-br>. Acesso em: 8 jan. 2014.

${ }^{76}$ Conforme dados divulgados pelas companhias listadas no Segmento do Novo Mercado, no item 3.1 da última versão dos respectivos dos respectivos Formulários de Referência divulgados até 31 de maio de 2013. Disponível em: <http://www.cvm.gov.br>. Acesso em: set. 2013.

${ }^{77}$ Valores divulgados em histórico mensal veiculado pela BM\&FBOVESPA, atualizado em 2 de janeiro de 2014, com relação ao mês de dezembro de 2013. Os valores divulgados se referem apenas a determinadas companhias, não havendo, portanto, informações de todas as companhias listadas no Novo Mercado, para as quais foram indicadas a não disponibilidade da informação (n/d). Disponível em: <http://www.bmfbovespa.com.br/capitalizacao-bursatil/ResumoBursatilMensal.aspx?idioma=pt-br>. Acesso em: 10 jan. 2014. 
Tabela 1 - Perfil das Companhias Listadas no Novo Mercado ${ }^{1}$

\begin{tabular}{|c|c|c|c|c|c|c|c|c|c|}
\hline$\#$ & Denominação & $\begin{array}{c}\text { Setor de } \\
\text { Atividade }^{70}\end{array}$ & $\begin{array}{c}\text { Data da } \\
\text { Constituição }^{71}\end{array}$ & $\begin{array}{l}\text { Data do } \\
\text { Registro } \\
\text { CVM }^{72}\end{array}$ & $\begin{array}{c}\text { Data da } \\
\text { Listagem } \\
\mathbf{N M}^{\mathbf{7 3}}\end{array}$ & $\begin{array}{c}\text { Integra } \\
\text { Ibovespa }^{74}\end{array}$ & $\begin{array}{l}\text { Integra } \\
\text { IBrX }^{75}\end{array}$ & $\begin{array}{c}\text { Patrimônio Líquido } \\
\text { Consolidado em } \\
\text { 31/12/2012 } \\
(\mathrm{em} \mathrm{R} \$)^{76}\end{array}$ & $\begin{array}{c}\text { Valor de Mercado } \\
\text { em Dez./2013 } \\
(\mathbf{R} \$)^{77}\end{array}$ \\
\hline 2 & $\begin{array}{l}\text { ALL América Latina } \\
\text { Logística S.A. }\end{array}$ & $\begin{array}{l}\text { Serviços Transporte e } \\
\text { Logística }\end{array}$ & 30/9/1997 & $7 / 2 / 1998$ & $22 / 10 / 2010$ & Sim & Sim & 4.203.747.299,19 & $4.511 .077 .890,00$ \\
\hline 3 & $\begin{array}{l}\text { Anhanguera Educacional } \\
\text { Participações S.A }\end{array}$ & Educação & $19 / 2 / 2001$ & $6 / 8 / 2001$ & $6 / 12 / 2010$ & Sim & Sim & $2.209 .140 .037,81$ & $6.512 .354 .670,00$ \\
\hline 4 & $\begin{array}{l}\text { Arezzo Indústria e } \\
\text { Comércio S.A. }\end{array}$ & Têxtil e Vestuário & 9/1/1972 & $31 / 1 / 2011$ & $2 / 2 / 2011$ & Não & Não & $453.899 .000,00$ & $\mathrm{n} / \mathrm{d}$ \\
\hline 5 & Arteris S.A. & $\begin{array}{l}\text { Construção Civil, Mat. } \\
\text { Constr. e Decoração }\end{array}$ & 24/11/1998 & $7 / 6 / 2005$ & $15 / 7 / 2005$ & Não & Não & $1.607 .084 .000,00$ & $6.561 .666 .580,00$ \\
\hline 6 & Autometal S.A. & $\begin{array}{l}\text { Máquinas, } \\
\text { Equipamentos, } \\
\text { Veículos e Peças }\end{array}$ & $12 / 11 / 1964$ & $3 / 2 / 2011$ & $7 / 2 / 2011$ & Não & Não & $1.607 .084 .000,00$ & $\mathrm{n} / \mathrm{d}$ \\
\hline 7 & B2W - Companhia Digital & $\begin{array}{l}\text { Comércio (Atacado e } \\
\text { Varejo) }\end{array}$ & $13 / 12 / 2006$ & $26 / 7 / 2007$ & $8 / 8 / 2007$ & Não & Não & $1.607 .084 .000,00$ & 2.427.917.810,00 \\
\hline 8 & Banco do Brasil S.A. & Bancos & $12 / 10 / 1808$ & 20/7/1977 & $28 / 6 / 2006$ & Sim & Sim & $69.898 .000 .000,00$ & $69.916 .175 .290,00$ \\
\hline 9 & $\begin{array}{l}\text { BB Seguridade } \\
\text { Participações S.A. }\end{array}$ & $\begin{array}{l}\text { Emp. Adm. Part. - } \\
\text { Seguradoras e } \\
\text { Corretoras }\end{array}$ & $20 / 12 / 2012$ & $25 / 4 / 2013$ & $29 / 4 / 2013$ & Sim & Sim & $5.638 .374 .000,00$ & $\mathrm{n} / \mathrm{d}$ \\
\hline 10 & Bematech S.A. & $\begin{array}{l}\text { Comunicação e } \\
\text { Informática }\end{array}$ & $10 / 1 / 1990$ & $17 / 4 / 2007$ & $19 / 4 / 2007$ & Não & Não & $374.760 .324,00$ & $\mathrm{n} / \mathrm{d}$ \\
\hline 11 & $\begin{array}{l}\text { BHG S.A. - Brazil } \\
\text { Hospitality Group }\end{array}$ & Hospedagem e Turismo & $14 / 3 / 2007$ & $12 / 7 / 2007$ & $16 / 7 / 2007$ & Não & Não & $761.953 .000,00$ & $\mathrm{n} / \mathrm{d}$ \\
\hline 12 & Biosev S.A. & $\begin{array}{l}\text { Agricultura (Açúcar, } \\
\text { Álcool e Cana) }\end{array}$ & $9 / 1 / 1982$ & $7 / 12 / 2012$ & $19 / 4 / 2013$ & Não & Não & $1.998 .115 .000,00$ & $\mathrm{n} / \mathrm{d}$ \\
\hline 13 & $\begin{array}{l}\text { BM\&FBovespa S.A. Bolsa } \\
\text { Valores Merc. Fut. }\end{array}$ & $\begin{array}{l}\text { Bolsas de } \\
\text { Valores/Mercadorias e } \\
\text { Futuros }\end{array}$ & $14 / 12 / 2007$ & $8 / 11 / 2008$ & $20 / 8 / 2008$ & Sim & Sim & $19.413 .882 .000,00$ & $21.898 .800 .000,00$ \\
\hline 14 & $\begin{array}{l}\text { BR Malls Participações } \\
\text { S.A. }\end{array}$ & $\begin{array}{l}\text { Comércio (Atacado e } \\
\text { Varejo) }\end{array}$ & $26 / 5 / 2004$ & $1 \frac{\mathrm{o}}{4} / 2 / 2006$ & $5 / 4 / 2007$ & Sim & Sim & $503.779 .000,00$ & $7.792 .980 .520,00$ \\
\hline
\end{tabular}


Tabela 1 - Perfil das Companhias Listadas no Novo Mercado ${ }^{1}$

\begin{tabular}{|c|c|c|c|c|c|c|c|c|c|}
\hline$\#$ & Denominação & $\begin{array}{c}\text { Setor de } \\
\text { Atividade }^{70}\end{array}$ & $\begin{array}{c}\text { Data da } \\
\text { Constituição }^{71}\end{array}$ & $\begin{array}{l}\text { Data do } \\
\text { Registro } \\
\text { CVM }^{72}\end{array}$ & $\begin{array}{c}\text { Data da } \\
\text { Listagem } \\
\mathrm{NM}^{73}\end{array}$ & $\mid \begin{array}{c}\text { Integra } \\
\text { Ibovespa }^{74}\end{array}$ & $\begin{array}{l}\text { Integra } \\
\mathrm{IBrX}^{75}\end{array}$ & $\begin{array}{c}\text { Patrimônio Líquido } \\
\text { Consolidado em } \\
\text { 31/12/2012 } \\
(\text { em R } \$)^{76}\end{array}$ & $\begin{array}{c}\text { Valor de Mercado } \\
\text { em Dez./2013 } \\
(\mathbf{R} \$)^{77}\end{array}$ \\
\hline 15 & BR Properties S.A. & $\begin{array}{l}\text { Emp. Adm. Part. - Sem } \\
\text { Setor Principal }\end{array}$ & $26 / 5 / 2004$ & $1 \% / 4 / 2006$ & $8 / 3 / 2010$ & Sim & Sim & $8.015 .267 .000,00$ & $5.815 .354 .080,00$ \\
\hline 16 & $\begin{array}{l}\text { Brasil Brokers } \\
\text { Participações S.A. }\end{array}$ & $\begin{array}{l}\text { Construção Civil, Mat. } \\
\text { Constr. e Decoração }\end{array}$ & $16 / 1 / 2007$ & $26 / 10 / 2007$ & $29 / 10 / 2007$ & Não & Não & $760.340 .000,00$ & $1.128 .111 .670,00$ \\
\hline 17 & $\begin{array}{l}\text { Brasil Insurance Particip. e } \\
\text { Administração S.A. }\end{array}$ & $\begin{array}{l}\text { Seguradoras e } \\
\text { Corretoras }\end{array}$ & $3 / 10 / 2010$ & $28 / 10 / 2010$ & $1 \% / 11 / 2010$ & Não & Não & $503.779 .000,00$ & $\mathrm{n} / \mathrm{d}$ \\
\hline 18 & Brasil Pharma S.A. & Farmacêutico e Higiene & $12 / 7 / 2009$ & $22 / 6 / 2011$ & $27 / 6 / 2011$ & Não & Não & $1.543 .120 .000,00$ & $\mathrm{n} / \mathrm{d}$ \\
\hline 19 & $\begin{array}{l}\text { Brasilagro - Cia. Bras. De } \\
\text { Prop. Agrícolas }\end{array}$ & $\begin{array}{l}\text { Agricultura (Açúcar, } \\
\text { Álcool e Cana) }\end{array}$ & $23 / 9 / 2005$ & $25 / 4 / 2006$ & $2 / 5 / 2006$ & Não & Não & $558.968 .000,00$ & $\mathrm{n} / \mathrm{d}$ \\
\hline 20 & BRF S.A. & Alimentos & $18 / 8 / 1934$ & $24 / 6 / 1997$ & $12 / 4 / 2006$ & Sim & Sim & $14.576 .040 .000,00$ & $42.969 .307 .370,00$ \\
\hline 21 & $\begin{array}{l}\text { Brookfield Incorporações } \\
\text { S.A. }\end{array}$ & $\begin{array}{l}\text { Construção Civil, Mat. } \\
\text { Constr. e Decoração }\end{array}$ & $14 / 11 / 2005$ & $9 / 11 / 2006$ & $23 / 10 / 2006$ & Sim & Sim & $2.853 .739 .000,00$ & $662.288 .120,00$ \\
\hline 22 & CCR S.A. & $\begin{array}{l}\text { Serviços Transporte e } \\
\text { Logística }\end{array}$ & $23 / 9 / 1998$ & $19 / 12 / 2000$ & $1 \frac{\mathrm{o}}{} / 2 / 2002$ & Sim & Sim & $3.362 .332 .000,00$ & $31.374 .484 .540,00$ \\
\hline 23 & $\begin{array}{l}\text { CCX Carvão da Colômbia } \\
\text { S.A. }\end{array}$ & Extração Mineral & $4 / 10 / 2006$ & $19 / 7 / 2006$ & $25 / 5 / 2012$ & Não & Não & $717.372 .000,00$ & $\mathrm{n} / \mathrm{d}$ \\
\hline 24 & $\begin{array}{l}\text { CETIP S.A. - Mercados } \\
\text { Organizados }\end{array}$ & $\begin{array}{l}\text { Intermediação } \\
\text { Financeira }\end{array}$ & $29 / 1 / 2008$ & $26 / 10 / 2009$ & $28 / 10 / 2009$ & Sim & Sim & $1.428 .082 .000,00$ & $6.301 .159 .190,00$ \\
\hline 25 & Cia Hering & Têxtil e Vestuário & $19 / 8 / 1985$ & $26 / 1 / 1995$ & $16 / 5 / 2007$ & Sim & Sim & $784.000 .007,00$ & $4.921 .874 .490,00$ \\
\hline 26 & $\begin{array}{l}\text { Cia Providência Indústria e } \\
\text { Comércio }\end{array}$ & $\begin{array}{l}\text { Petroquímicos e } \\
\text { Borracha }\end{array}$ & $7 / 4 / 1963$ & $25 / 7 / 2007$ & $27 / 7 / 2007$ & Não & Não & $689.977 .298,69$ & $\mathrm{n} / \mathrm{d}$ \\
\hline 27 & $\begin{array}{l}\text { Cia Saneamento Básico } \\
\text { Est. São Paulo }\end{array}$ & $\begin{array}{l}\text { Saneamento, Serv. } \\
\text { Água e Gás }\end{array}$ & $9 / 6 / 1973$ & 27/6/1994 & $23 / 4 / 2012$ & Sim & Sim & $11.715 .577 .000,00$ & $18.085 .671 .130,00$ \\
\hline 28 & $\begin{array}{l}\text { Cia Saneamento de Minas } \\
\text { Gerais - COPASA MG }\end{array}$ & $\begin{array}{l}\text { Saneamento, Serv. } \\
\text { Água e Gás }\end{array}$ & $7 / 5 / 1963$ & $17 / 9 / 2003$ & $8 / 2 / 2006$ & Não & Não & $4.990 .264 .000,00$ & $4.452 .260 .800,00$ \\
\hline
\end{tabular}


Tabela 1 - Perfil das Companhias Listadas no Novo Mercado ${ }^{1}$

\begin{tabular}{|c|c|c|c|c|c|c|c|c|c|}
\hline$\#$ & Denominação & $\begin{array}{c}\text { Setor de } \\
\text { Atividade }^{70}\end{array}$ & $\begin{array}{c}\text { Data da } \\
\text { Constituiçãa }^{71}\end{array}$ & $\begin{array}{l}\text { Data do } \\
\text { Registro } \\
\text { CVM }^{72}\end{array}$ & $\begin{array}{c}\text { Data da } \\
\text { Listagem } \\
\mathbf{N M}^{\mathbf{7 3}}\end{array}$ & $\begin{array}{c}\text { Integra } \\
\text { Ibovespa }^{74}\end{array}$ & $\begin{array}{l}\text { Integra } \\
\text { IBrX }^{75}\end{array}$ & $\begin{array}{c}\text { Patrimônio Líquido } \\
\text { Consolidado em } \\
\text { 31/12/2012 } \\
(\text { em R\$) }\end{array}$ & $\begin{array}{c}\text { Valor de Mercado } \\
\text { em Dez./2013 } \\
(\mathbf{R} \$)^{77}\end{array}$ \\
\hline 29 & Cielo S.A. & $\begin{array}{l}\text { Intermediação } \\
\text { Financeira }\end{array}$ & 23/11/1995 & $25 / 6 / 2009$ & $29 / 6 / 2009$ & Sim & Sim & $2.286 .107 .000,00$ & $51.608 .480 .540,00$ \\
\hline 30 & $\begin{array}{l}\text { Companhia de Locação } \\
\text { das Américas }\end{array}$ & $\begin{array}{l}\text { Serviços Transporte e } \\
\text { Logística }\end{array}$ & $18 / 7 / 2008$ & $30 / 12 / 2011$ & $23 / 4 / 2012$ & Não & Não & $301.795 .000,00$ & $\mathrm{n} / \mathrm{d}$ \\
\hline 31 & $\begin{array}{l}\text { Cosan S.A. Indústria e } \\
\text { Comércio }\end{array}$ & $\begin{array}{l}\text { Agricultura (Açúcar, } \\
\text { Álcool e Cana) }\end{array}$ & $7 / 8 / 1966$ & $26 / 10 / 2005$ & $18 / 11 / 2005$ & Sim & Sim & $9.616 .374 .000,00$ & 16.117.544.090,00 \\
\hline 32 & CPFL Energia S.A. & Energia Elétrica & $26 / 10 / 2005$ & $18 / 5 / 2000$ & $29 / 9 / 2004$ & Sim & Sim & $8.407 .061 .000,00$ & $18.369 .815 .620,00$ \\
\hline 33 & $\begin{array}{l}\text { CR2 Empreendimentos } \\
\text { Imobiliários S.A. }\end{array}$ & $\begin{array}{l}\text { Construção Civil, Mat. } \\
\text { Constr. e Decoração }\end{array}$ & $1 \% / 10 / 2006$ & $16 / 4 / 2007$ & $23 / 4 / 2007$ & Não & Não & $413.615 .000,00$ & $\mathrm{n} / \mathrm{d}$ \\
\hline 34 & Cremer S.A. & Têxtil e Vestuário & $30 / 3 / 1935$ & $30 / 6 / 2006$ & $30 / 4 / 2007$ & Não & Não & $279.656 .690,23$ & $\mathrm{n} / \mathrm{d}$ \\
\hline 35 & CSU Cardsystem S.A. & $\begin{array}{l}\text { Emp. Adm. Part. - Sem } \\
\text { Setor Principal }\end{array}$ & $18 / 4 / 1997$ & $25 / 4 / 2006$ & $2 / 5 / 2006$ & Não & Não & $161.316 .364,00$ & $\mathrm{n} / \mathrm{d}$ \\
\hline 36 & $\begin{array}{l}\text { Cyrela Brazil Realty S.A. } \\
\text { Empreend. Part. }\end{array}$ & $\begin{array}{l}\text { Construção Civil, Mat. } \\
\text { Constr. e Decoração }\end{array}$ & $12 / 1 / 1993$ & 7/7/1994 & $21 / 9 / 2005$ & Sim & Sim & $5.393 .306 .930,72$ & $5.999 .887 .140,00$ \\
\hline 37 & $\begin{array}{l}\text { Cyrela Commercial } \\
\text { Properties S.A. Empr. Part. }\end{array}$ & $\begin{array}{l}\text { Construção Civil, Mat. } \\
\text { Constr. e Decoração }\end{array}$ & $4 / 11 / 2007$ & $8 / 1 / 2007$ & $9 / 8 / 2007$ & Não & Não & $628.503 .000,00$ & $\mathrm{n} / \mathrm{d}$ \\
\hline 38 & $\begin{array}{l}\text { Diagnósticos da América } \\
\text { S.A. }\end{array}$ & Serviços médicos & $7 / 7 / 1966$ & $11 / 5 / 2004$ & $19 / 11 / 2004$ & Sim & Sim & 2.606.810.097,99 & $4.539 .851 .900,00$ \\
\hline 39 & $\begin{array}{l}\text { Direcional Engenharia } \\
\text { S.A. }\end{array}$ & $\begin{array}{l}\text { Construção Civil, Mat. } \\
\text { Constr. e Decoração }\end{array}$ & $19 / 2 / 1981$ & $29 / 2 / 2008$ & $19 / 11 / 2009$ & Não & Não & $1.421 .358 .000,00$ & $\mathrm{n} / \mathrm{d}$ \\
\hline 40 & Duratex S.A. & $\begin{array}{l}\text { Construção Civil, Mat. } \\
\text { Constr. e Decoração }\end{array}$ & $25 / 1 / 1962$ & $9 / 10 / 2007$ & $21 / 9 / 2007$ & Sim & Sim & $4.023 .605 .249,76$ & $7.956 .532 .280,00$ \\
\hline 41 & $\begin{array}{l}\text { Ecorodovias Infraestrutura } \\
\text { e Logística S.A. }\end{array}$ & $\begin{array}{l}\text { Serviços Transporte e } \\
\text { Logística }\end{array}$ & $11 / 7 / 2000$ & $24 / 9 / 2003$ & $1 \% / 4 / 2010$ & Sim & Sim & $2.125 .487 .662,04$ & $8.268 .746 .380,00$ \\
\hline 42 & $\begin{array}{l}\text { EDP - Energias do Brasil } \\
\text { S.A. }\end{array}$ & Energia Elétrica & $24 / 7 / 2000$ & $7 / 5 / 2005$ & $13 / 7 / 2005$ & Sim & Sim & $6.350 .203 .000,00$ & $5.407 .317 .200,00$ \\
\hline
\end{tabular}


Tabela 1 - Perfil das Companhias Listadas no Novo Mercado ${ }^{1}$

\begin{tabular}{|c|c|c|c|c|c|c|c|c|c|}
\hline$\#$ & Denominação & $\begin{array}{c}\text { Setor de } \\
\text { Atividade }^{70}\end{array}$ & $\begin{array}{c}\text { Data da } \\
\text { Constituição }^{71}\end{array}$ & $\begin{array}{l}\text { Data do } \\
\text { Registro } \\
\text { CVM }^{72}\end{array}$ & $\begin{array}{c}\text { Data da } \\
\text { Listagem } \\
\mathbf{N M}^{\mathbf{7 3}}\end{array}$ & $\begin{array}{c}\text { Integra } \\
\text { Ibovespa }^{74}\end{array}$ & $\begin{array}{l}\text { Integra } \\
\text { IBrX }^{75}\end{array}$ & $\begin{array}{c}\text { Patrimônio Líquido } \\
\text { Consolidado em } \\
\text { 31/12/2012 } \\
(\text { em R\$) }\end{array}$ & $\begin{array}{c}\text { Valor de Mercado } \\
\text { em Dez./2013 } \\
(\mathbf{R} \$)^{77}\end{array}$ \\
\hline 43 & Embraer S.A. & $\begin{array}{l}\text { Máquinas, Equipamentos, } \\
\text { Veículos e Peças }\end{array}$ & $23 / 5 / 2006$ & $23 / 5 / 2006$ & $5 / 6 / 2006$ & Sim & Sim & $6.846 .482 .044,74$ & 13.987.384.680,00 \\
\hline 44 & Equatorial Energia S.A. & Energia Elétrica & $16 / 6 / 1999$ & $30 / 3 / 2006$ & $23 / 4 / 2008$ & Não & Não & $2.527 .525 .000,00$ & $4.594 .056 .200,00$ \\
\hline 45 & Estácio Participações S.A. & Educação & $31 / 3 / 2007$ & $26 / 7 / 2007$ & $11 / 7 / 2008$ & Sim & Sim & $707.035 .458,96$ & $6.025 .279 .900,00$ \\
\hline 46 & Eternit S.A. & $\begin{array}{l}\text { Construção Civil, Mat. } \\
\text { Constr. e Decoração }\end{array}$ & $30 / 1 / 1940$ & $17 / 11 / 1970$ & $17 / 8 / 2006$ & Não & Não & $479.534 .000,00$ & $\mathrm{n} / \mathrm{d}$ \\
\hline 47 & $\begin{array}{l}\text { Even Construtora e } \\
\text { Incorporadora S.A. }\end{array}$ & $\begin{array}{l}\text { Construção Civil, Mat. } \\
\text { Constr. e Decoração }\end{array}$ & $5 / 5 / 1980$ & $3 / 2 / 2007$ & $2 / 4 / 2007$ & Sim & Sim & $1.805 .093 .495,13$ & $1.901 .341 .280,00$ \\
\hline 48 & $\begin{array}{l}\text { EZ TEC Empreend. e } \\
\text { Participações S.A. }\end{array}$ & $\begin{array}{l}\text { Construção Civil, Mat. } \\
\text { Constr. e Decoração }\end{array}$ & $31 / 7 / 2006$ & $15 / 6 / 2007$ & $22 / 6 / 2007$ & Não & Não & $1.654 .661 .337,50$ & $4.275 .540 .860,00$ \\
\hline 49 & Fertilizantes Heringer S.A. & $\begin{array}{l}\text { Petroquímicos e } \\
\text { Borracha }\end{array}$ & $23 / 9 / 1968$ & $4 / 10 / 2007$ & $12 / 4 / 2007$ & Não & Não & $471.146 .320,45$ & $\mathrm{n} / \mathrm{d}$ \\
\hline 50 & Fibria Celulose S.A. & Papel e Celulose & $25 / 7 / 1941$ & $6 / 2 / 1986$ & $20 / 5 / 2010$ & Sim & Sim & $15.192 .965 .000,00$ & $\mathrm{n} / \mathrm{d}$ \\
\hline 51 & Fleury S.A. & Serviços médicos & $23 / 10 / 1964$ & $14 / 12 / 2009$ & $17 / 12 / 2009$ & Não & Não & $1.705 .908 .000,00$ & $\mathrm{n} / \mathrm{d}$ \\
\hline 52 & Gafisa S.A. & $\begin{array}{l}\text { Construção Civil, Mat. } \\
\text { Constr. e Decoração }\end{array}$ & $11 / 12 / 1996$ & $21 / 2 / 1997$ & $17 / 2 / 2006$ & Sim & Sim & $2.692 .367 .000,00$ & $1.537 .523 .980,00$ \\
\hline 53 & $\begin{array}{l}\text { General Shopping Brasil } \\
\text { S.A. }\end{array}$ & $\begin{array}{l}\text { Emp. Adm. Part. - Sem } \\
\text { Setor Principal }\end{array}$ & $3 / 6 / 2007$ & $26 / 7 / 2007$ & $30 / 7 / 2007$ & Não & Não & $242.873 .000,00$ & $\mathrm{n} / \mathrm{d}$ \\
\hline 54 & Grendene S.A. & Têxtil e Vestuário & $25 / 2 / 1971$ & $26 / 10 / 2004$ & $29 / 10 / 2004$ & Não & Não & $1.953 .562 .189,21$ & $\mathrm{n} / \mathrm{d}$ \\
\hline 55 & $\begin{array}{l}\text { Helbor Empreendimentos } \\
\text { S.A. }\end{array}$ & $\begin{array}{l}\text { Construção Civil, Mat. } \\
\text { Constr. e Decoração }\end{array}$ & 20/10/1977 & $7 / 9 / 2007$ & $29 / 10 / 2007$ & Não & Não & $846.197 .000,00$ & $\mathrm{n} / \mathrm{d}$ \\
\hline 56 & $\begin{array}{l}\text { HRT Participações em } \\
\text { Petróleo S.A. }\end{array}$ & Petróleo e Gás & $13 / 10 / 2008$ & $21 / 10 / 2010$ & $25 / 10 / 2010$ & Não & Não & $3.659 .376 .392,92$ & $270.694 .740,00$ \\
\hline
\end{tabular}


Tabela 1 - Perfil das Companhias Listadas no Novo Mercado ${ }^{1}$

\begin{tabular}{|c|c|c|c|c|c|c|c|c|c|}
\hline$\#$ & Denominação & $\begin{array}{c}\text { Setor de } \\
\text { Atividade }^{70}\end{array}$ & $\begin{array}{c}\text { Data da } \\
\text { Constituição }^{71}\end{array}$ & $\begin{array}{l}\text { Data do } \\
\text { Registro } \\
\text { CVM }^{72}\end{array}$ & $\begin{array}{c}\text { Data da } \\
\text { Listagem } \\
\mathbf{N M}^{73}\end{array}$ & $\begin{array}{c}\text { Integra } \\
\text { Ibovespa }^{74}\end{array}$ & $\begin{array}{l}\text { Integra } \\
\operatorname{IBrX}^{75}\end{array}$ & \begin{tabular}{|c|} 
Patrimônio Líquido \\
Consolidado em \\
$31 / 12 / 2012$ \\
$($ em R\$) \\
\end{tabular} & $\begin{array}{c}\text { Valor de Mercado } \\
\text { em Dez./2013 } \\
(\mathbf{R} \$)^{77}\end{array}$ \\
\hline 57 & Hypermarcas S.A. & $\begin{array}{l}\text { Comércio (Atacado e } \\
\text { Varejo) }\end{array}$ & $12 / 1 / 2001$ & $16 / 4 / 2008$ & $18 / 4 / 2008$ & Sim & Sim & $6.868 .366 .590,10$ & $11.156 .578 .890,00$ \\
\hline 58 & Ideiasnet S.A. & $\begin{array}{l}\text { Comunicação e } \\
\text { Informática }\end{array}$ & 26/1/1998 & 8/2/1999 & $15 / 1 / 2008$ & Não & Não & $118.963,00$ & $\mathrm{n} / \mathrm{d}$ \\
\hline 59 & $\begin{array}{l}\text { Iguatemi Empresa de } \\
\text { Shopping Centers S.A }\end{array}$ & $\begin{array}{l}\text { Comércio (Atacado e } \\
\text { Varejo) }\end{array}$ & $23 / 5 / 1979$ & $2 / 2 / 2007$ & $7 / 2 / 2007$ & Não & Não & $1.827 .316 .000,00$ & $\mathrm{n} / \mathrm{d}$ \\
\hline 60 & Indústrias Romi S.A. & $\begin{array}{l}\text { Máquinas, } \\
\text { Equipamentos, } \\
\text { Veículos e Peças }\end{array}$ & $19 / 4 / 1938$ & $19 / 4 / 1938$ & $23 / 3 / 2007$ & Não & Não & $637.270 .000,00$ & $\mathrm{n} / \mathrm{d}$ \\
\hline 61 & $\begin{array}{l}\text { International Meal } \\
\text { Company Holdings S.A. }\end{array}$ & Alimentos & $15 / 6 / 2007$ & $3 / 3 / 2011$ & $9 / 3 / 2011$ & Não & Não & $879.037 .371,89$ & $\mathrm{n} / \mathrm{d}$ \\
\hline 62 & Iochpe Maxion S.A. & $\begin{array}{l}\text { Máquinas, } \\
\text { Equipamentos, } \\
\text { Veículos e Peças }\end{array}$ & $10 / 6 / 1969$ & $17 / 7 / 1984$ & $24 / 3 / 2008$ & Não & Não & $1.090 .910 .000,00$ & $2.480 .677 .180,00$ \\
\hline 63 & JBS S.A. & Alimentos & $16 / 12 / 1998$ & $27 / 3 / 2007$ & $29 / 3 / 2008$ & Sim & Sim & $21.433 .306 .000,00$ & $25.815 .757 .950,00$ \\
\hline 64 & JHSF Participações S.A. & $\begin{array}{l}\text { Construção Civil, Mat. } \\
\text { Constr. e Decoração }\end{array}$ & $29 / 6 / 2006$ & $4 / 4 / 2007$ & $12 / 4 / 2007$ & Não & Não & $1.298 .382 .000,00$ & $\mathrm{n} / \mathrm{d}$ \\
\hline 65 & JSL S.A. & $\begin{array}{l}\text { Serviços Transporte e } \\
\text { Logística }\end{array}$ & $8 / 5 / 1969$ & $15 / 4 / 2010$ & $22 / 4 / 2010$ & Não & Não & $979.400 .000,00$ & $\mathrm{n} / \mathrm{d}$ \\
\hline 66 & Kroton Educacional S.A. & Educação & 26/8/1998 & $12 / 1 / 1998$ & $5 / 12 / 2012$ & Sim & Sim & $2.246 .204 .000,00$ & $10.549 .314 .170,00$ \\
\hline 67 & Light S.A. & Energia Elétrica & 27/7/1999 & $12 / 12 / 2005$ & $22 / 2 / 2006$ & Sim & Sim & $3.025 .683 .000,00$ & $4.511 .021 .410,00$ \\
\hline 68 & Linx S.A. & $\begin{array}{l}\text { Comunicação e } \\
\text { Informática }\end{array}$ & $20 / 7 / 2004$ & $2 / 6 / 2013$ & $8 / 2 / 2013$ & Não & Não & $233.441 .563,26$ & $1.919 .672 .690,00$ \\
\hline 69 & LLX Logística S.A. & $\begin{array}{l}\text { Serviços Transporte e } \\
\text { Logística }\end{array}$ & $3 / 1 / 2007$ & $6 / 12 / 2008$ & $28 / 7 / 2008$ & Sim & Sim & $937.187 .000,00$ & 7.048.484.350,00 \\
\hline
\end{tabular}


Tabela 1 - Perfil das Companhias Listadas no Novo Mercado ${ }^{1}$

\begin{tabular}{|c|c|c|c|c|c|c|c|c|c|}
\hline$\#$ & Denominação & $\begin{array}{c}\text { Setor de } \\
\text { Atividade }^{70}\end{array}$ & $\begin{array}{c}\text { Data da } \\
\text { Constituição }^{71}\end{array}$ & $\begin{array}{l}\text { Data do } \\
\text { Registro } \\
\text { CVM }^{72}\end{array}$ & $\begin{array}{c}\text { Data da } \\
\text { Listagem } \\
\mathbf{N M}^{73}\end{array}$ & $\begin{array}{c}\text { Integra } \\
\text { Ibovespa }^{74}\end{array}$ & $\begin{array}{l}\text { Integra } \\
\mathrm{IBrX}^{75}\end{array}$ & $\begin{array}{c}\text { Patrimônio Líquido } \\
\text { Consolidado em } \\
31 / 12 / 2012 \\
(\text { em R\$) }\end{array}$ & $\begin{array}{c}\text { Valor de Mercado } \\
\text { em Dez./2013 } \\
(\mathbf{R} \$)^{77}\end{array}$ \\
\hline 70 & Localiza Rent a Car S.A. & $\begin{array}{l}\text { Serviços Transporte e } \\
\text { Logística }\end{array}$ & 28/9/1973 & $5 / 6 / 2005$ & $23 / 5 / 2005$ & Sim & Sim & $1.324 .753 .000,00$ & $\mathrm{n} / \mathrm{d}$ \\
\hline 71 & $\begin{array}{l}\text { Log-in Logística } \\
\text { Intermodal S.A. }\end{array}$ & $\begin{array}{l}\text { Serviços Transporte e } \\
\text { Logística }\end{array}$ & $9 / 4 / 1973$ & $6 / 4 / 2007$ & $21 / 6 / 2007$ & Não & Não & $530.067 .000,00$ & $\mathrm{n} / \mathrm{d}$ \\
\hline 72 & Lojas Renner S.A. & $\begin{array}{l}\text { Comércio (Atacado e } \\
\text { Varejo) }\end{array}$ & $6 / 10 / 1965$ & 20/7/1977 & $1^{\mathrm{o}} / 7 / 2005$ & Sim & Sim & $1.305 .683 .046,87$ & 7.679.586.770,00 \\
\hline 73 & $\begin{array}{l}\text { LPS Brasil - Consultoria } \\
\text { de Imóveis S.A. }\end{array}$ & $\begin{array}{l}\text { Construção Civil, Mat. } \\
\text { Constr. e Decoração }\end{array}$ & $22 / 5 / 2006$ & $12 / 12 / 2006$ & $18 / 12 / 2006$ & Não & Não & $636.485 .000,00$ & $\mathrm{n} / \mathrm{d}$ \\
\hline 74 & Lupatech S.A. & Petróleo e Gás & $8 / 8 / 1980$ & $5 / 8 / 2006$ & $15 / 5 / 2006$ & Não & Não & $(189.750 .686,34)$ & $\mathrm{n} / \mathrm{d}$ \\
\hline 75 & $\begin{array}{l}\text { M. Dias Branco S.A. Ind. } \\
\text { Com. de Alimentos }\end{array}$ & Alimentos & $21 / 5 / 1951$ & $10 / 11 / 2006$ & $18 / 10 / 2006$ & Não & Não & $2.410 .615 .910,24$ & $\mathrm{n} / \mathrm{d}$ \\
\hline 76 & Magazine Luiza S.A. & $\begin{array}{l}\text { Comércio (Atacado e } \\
\text { Varejo) }\end{array}$ & $30 / 10 / 1957$ & $28 / 4 / 2011$ & $2 / 5 / 2011$ & Não & Não & $615.992 .000,00$ & $\mathrm{n} / \mathrm{d}$ \\
\hline 77 & Magnesita Refratários S.A. & Extração Mineral & $12 / 11 / 2006$ & $7 / 2 / 2007$ & $2 / 4 / 2008$ & Não & Não & $2.810 .859 .000,00$ & $\mathrm{n} / \mathrm{d}$ \\
\hline 78 & Mahle-Metal Leve S.A. & $\begin{array}{l}\text { Máquinas, } \\
\text { Equipamentos, } \\
\text { Veículos e Peças }\end{array}$ & $3 / 3 / 1950$ & 20/7/1977 & $5 / 7 / 2011$ & Não & Não & $1.362 .226 .000,00$ & $\mathrm{n} / \mathrm{d}$ \\
\hline 79 & Marfrig Alimentos S.A. & Alimentos & $6 / 6 / 2000$ & $18 / 6 / 2007$ & $29 / 6 / 2007$ & Sim & Sim & $4.305 .092 .000,00$ & $2.082 .989 .620,00$ \\
\hline 80 & Marisa Lojas S.A. & $\begin{array}{l}\text { Comércio (Atacado e } \\
\text { Varejo) }\end{array}$ & 28/4/1959 & 28/4/1959 & $28 / 6 / 2010$ & Não & Não & $1.039 .049 .000,00$ & $\mathrm{n} / \mathrm{d}$ \\
\hline 81 & Metalfrio Solutions S.A. & $\begin{array}{l}\text { Máquinas, } \\
\text { Equipamentos, } \\
\text { Veículos e Peças }\end{array}$ & $12 / 3 / 2001$ & $4 / 10 / 2007$ & $13 / 4 / 2007$ & Não & Não & $279.516 .660,71$ & $\mathrm{n} / \mathrm{d}$ \\
\hline 82 & $\begin{array}{l}\text { Mills Estrutura e Serviços } \\
\text { de Engenharia S.A. }\end{array}$ & $\begin{array}{l}\text { Construção Civil, Mat. } \\
\text { Constr. e Decoração }\end{array}$ & $12 / 1 / 1980$ & $14 / 4 / 2010$ & $16 / 4 / 2010$ & Não & Não & $859.326 .000,00$ & 4.203.737.870,00 \\
\hline
\end{tabular}


Tabela 1 - Perfil das Companhias Listadas no Novo Mercado ${ }^{1}$

\begin{tabular}{|c|c|c|c|c|c|c|c|c|c|}
\hline \# & Denominação & $\begin{array}{c}\text { Setor de } \\
\text { Atividade }^{70}\end{array}$ & $\begin{array}{c}\text { Data da } \\
\text { Constituiçãa }^{71}\end{array}$ & $\begin{array}{l}\text { Data do } \\
\text { Registro } \\
\text { CVM }^{72}\end{array}$ & $\begin{array}{c}\text { Data da } \\
\text { Listagem } \\
\mathbf{N M}^{\mathbf{7 3}}\end{array}$ & $\begin{array}{c}\text { Integra } \\
\text { Ibovespa }^{74}\end{array}$ & $\begin{array}{l}\text { Integra } \\
\text { IBrX }^{75}\end{array}$ & \begin{tabular}{|c} 
Patrimônio Líquido \\
Consolidado em \\
$31 / 12 / 2012$ \\
$(\mathrm{em} \mathrm{R} \$)^{76}$
\end{tabular} & $\begin{array}{c}\text { Valor de Mercado } \\
\text { em Dez./2013 } \\
(\mathbf{R} \$)^{77}\end{array}$ \\
\hline 83 & Minerva S.A. & Alimentos & $3 / 9 / 1992$ & $18 / 7 / 2007$ & $20 / 7 / 2007$ & Não & Não & $751.889 .000,00$ & $1.668 .144 .260,00$ \\
\hline 84 & $\begin{array}{l}\text { MMX Mineração e } \\
\text { Metálicos S.A. }\end{array}$ & Extração Mineral & 26/8/1998 & $11 / 10 / 1998$ & $24 / 7 / 2006$ & Não & Não & $3.449 .849 .000,00$ & $681.259 .210,00$ \\
\hline 85 & MPX Energia S.A. & Energia Elétrica & $25 / 4 / 2001$ & $12 / 7 / 2007$ & $14 / 12 / 2007$ & Não & Não & $2.452 .347 .000,00$ & $\mathrm{n} / \mathrm{d}$ \\
\hline 86 & $\begin{array}{l}\text { MRV Engenharia e } \\
\text { Participações S.A. }\end{array}$ & $\begin{array}{l}\text { Construção Civil, Mat. } \\
\text { Constr. e Decoração }\end{array}$ & $31 / 5 / 2006$ & $13 / 7 / 2007$ & $23 / 7 / 2007$ & Sim & Sim & 4.087.973.000,00 & $4.072 .551 .730,00$ \\
\hline 87 & Multiplus S.A. & $\begin{array}{l}\text { Comércio (Atacado e } \\
\text { Varejo) }\end{array}$ & $8 / 6 / 2009$ & $2 / 3 / 2010$ & $5 / 2 / 2010$ & Não & Não & $149.246 .000,00$ & $\mathrm{n} / \mathrm{d}$ \\
\hline 88 & Natura Cosméticos S.A. & Farmacêutico e Higiene & 28/8/1969 & $21 / 5 / 2004$ & $26 / 5 / 2004$ & Sim & Sim & $1.306 .096 .118,92$ & $17.840 .368 .350,00$ \\
\hline 89 & Odontoprev S.A. & Serviços médicos & $28 / 8 / 1987$ & $13 / 6 / 2006$ & $01 / 12 / 06$ & Não & Não & $701.301 .530,38$ & $5.222 .627 .810,00$ \\
\hline 90 & $\begin{array}{l}\text { OGX Petróleo e Gás } \\
\text { Participações S.A. }\end{array}$ & Petróleo e Gás & $4 / 10 / 2006$ & $19 / 7 / 2006$ & $13 / 6 / 2008$ & Não & Não & $6.934 .719 .567,00$ & $\mathrm{n} / \mathrm{d}$ \\
\hline 91 & OSX Brasil S.A. & $\begin{array}{l}\text { Emp. Adm. Part. - Sem } \\
\text { Setor Principal }\end{array}$ & $3 / 9 / 2007$ & $26 / 2 / 2008$ & $22 / 3 / 2010$ & Não & Não & $3.808 .163 .363,19$ & $\mathrm{n} / \mathrm{d}$ \\
\hline 92 & Paranapanema S.A. & Metalurgia e Siderurgia & $15 / 5 / 1961$ & 20/7/1977 & $15 / 2 / 2012$ & Não & Não & $1.461 .730 .000,00$ & $\mathrm{n} / \mathrm{d}$ \\
\hline 93 & $\begin{array}{l}\text { PDG Realty S.A. } \\
\text { Empreend. e Participações }\end{array}$ & $\begin{array}{l}\text { Construção Civil, Mat. } \\
\text { Constr. e Decoração }\end{array}$ & $17 / 11 / 1998$ & $23 / 1 / 2007$ & $26 / 1 / 2007$ & Sim & Sim & $5.030 .113 .000,00$ & $2.424 .581 .740,00$ \\
\hline 94 & Porto Seguro S.A. & $\begin{array}{l}\text { Seguradoras e } \\
\text { Corretoras }\end{array}$ & $22 / 9 / 1997$ & 28/11/1997 & $22 / 11 / 2004$ & Não & Não & $5.069 .387 .000,00$ & $9.617 .967 .640,00$ \\
\hline 95 & Portobello S.A. & $\begin{array}{l}\text { Construção Civil, Mat. } \\
\text { Constr. e Decoração }\end{array}$ & $22 / 12 / 1977$ & $1 \stackrel{0}{1} / 4 / 1991$ & $30 / 4 / 2008$ & Não & Não & 127.127.381,84 & $\mathrm{n} / \mathrm{d}$ \\
\hline 96 & Positivo Informática S.A. & $\begin{array}{l}\text { Comunicação e } \\
\text { Informática }\end{array}$ & $26 / 5 / 1989$ & $12 / 6 / 2006$ & $11 / 12 / 2006$ & Não & Não & $640.032 .000,00$ & $\mathrm{n} / \mathrm{d}$ \\
\hline
\end{tabular}


Tabela 1 - Perfil das Companhias Listadas no Novo Mercado ${ }^{1}$

\begin{tabular}{|c|c|c|c|c|c|c|c|c|c|}
\hline$\#$ & Denominação & $\begin{array}{c}\text { Setor de } \\
\text { Atividade }^{70}\end{array}$ & $\begin{array}{c}\text { Data da } \\
\text { Constituição }^{71}\end{array}$ & $\begin{array}{l}\text { Data do } \\
\text { Registro } \\
\text { CVM }^{72}\end{array}$ & $\begin{array}{c}\text { Data da } \\
\text { Listagem } \\
\mathbf{N M}^{73}\end{array}$ & $\mid \begin{array}{c}\text { Integra } \\
\text { Ibovespa }^{74}\end{array}$ & $\begin{array}{l}\text { Integra } \\
\text { IBrX }^{75}\end{array}$ & $\begin{array}{c}\text { Patrimônio Líquido } \\
\text { Consolidado em } \\
31 / 12 / 2012 \\
(\text { em R\$) }\end{array}$ & $\begin{array}{c}\text { Valor de Mercado } \\
\text { em Dez./2013 } \\
(\mathbf{R} \$)^{77}\end{array}$ \\
\hline 97 & $\begin{array}{l}\text { Profarma Distrib. Prod. } \\
\text { Farmacêuticos S.A. }\end{array}$ & $\begin{array}{l}\text { Comércio (Atacado e } \\
\text { Varejo) }\end{array}$ & $23 / 5 / 1961$ & $24 / 10 / 2006$ & $26 / 10 / 2006$ & Não & Não & $570.929 .345,77$ & $\mathrm{n} / \mathrm{d}$ \\
\hline 98 & QGEP Participações S.A. & Petróleo e Gás & $3 / 9 / 2010$ & $2 / 2 / 2011$ & $9 / 2 / 2011$ & Não & Não & $1.992 .204 .515,57$ & $2.599 .591 .530,00$ \\
\hline 99 & Qualicorp S.A. & $\begin{array}{l}\text { Emp. Adm. Part. - Sem } \\
\text { Setor Principal }\end{array}$ & $2 / 12 / 2010$ & $17 / 6 / 2011$ & $29 / 6 / 2011$ & Sim & Sim & $1.992 .204 .515,57$ & $5.998 .559 .330,00$ \\
\hline 100 & Raia Drogasil S.A. & $\begin{array}{l}\text { Comércio (Atacado e } \\
\text { Varejo) }\end{array}$ & $28 / 3 / 1935$ & 20/7/1977 & $3 / 7 / 2007$ & Não & Não & $2.264 .659 .000,00$ & $4.883 .105 .080,00$ \\
\hline 101 & Renar Maçãs S.A. & $\begin{array}{l}\text { Agricultura (Açúcar, } \\
\text { Álcool e Cana) }\end{array}$ & $11 / 1 / 1962$ & $28 / 12 / 2004$ & $28 / 2 / 2005$ & Não & Não & $2.227 .796 .757,24$ & $\mathrm{n} / \mathrm{d}$ \\
\hline 102 & $\begin{array}{l}\text { Restoque Com. e } \\
\text { Confecções de Roupas } \\
\text { S.A. }\end{array}$ & $\begin{array}{l}\text { Comércio (Atacado e } \\
\text { Varejo) }\end{array}$ & $19 / 4 / 1982$ & $18 / 4 / 2008$ & $29 / 4 / 2008$ & Não & Não & $208.045 .000,00$ & $\mathrm{n} / \mathrm{d}$ \\
\hline 103 & $\begin{array}{l}\text { Rodobens Negócios } \\
\text { Imobiliários S.A. }\end{array}$ & $\begin{array}{l}\text { Construção Civil, Mat. } \\
\text { Constr. e Decoração }\end{array}$ & $16 / 10 / 1991$ & $18 / 1 / 2007$ & $31 / 1 / 2007$ & Não & Não & $776.597 .000,00$ & $\mathrm{n} / \mathrm{d}$ \\
\hline 104 & Rossi Residencial S.A. & $\begin{array}{l}\text { Construção Civil, Mat. } \\
\text { Constr. e Decoração }\end{array}$ & $27 / 6 / 1985$ & $7 / 1 / 1997$ & $27 / 1 / 2006$ & Sim & Sim & $2.298 .112 .577,57$ & $874.085 .780,00$ \\
\hline 105 & $\begin{array}{l}\text { São Carlos } \\
\text { Empreendimentos e } \\
\text { Participações S.A. }\end{array}$ & $\begin{array}{l}\text { Emp. Adm. Part. - Sem } \\
\text { Setor Principal }\end{array}$ & $15 / 6 / 1999$ & $25 / 3 / 1991$ & $14 / 12 / 2006$ & Não & Não & $896.658 .000,00$ & $\mathrm{n} / \mathrm{d}$ \\
\hline 106 & São Martinho S.A. & $\begin{array}{l}\text { Agricultura (Açúcar, } \\
\text { Álcool e Cana) }\end{array}$ & $13 / 7 / 1943$ & $2 / 7 / 2007$ & $12 / 2 / 2007$ & Não & Não & $2.024 .678,00^{78}$ & $\mathrm{n} / \mathrm{d}$ \\
\hline 107 & Sonae Sierra Brasil S.A. & $\begin{array}{l}\text { Construção Civil, Mat. } \\
\text { Constr. e Decoração }\end{array}$ & $17 / 6 / 2003$ & $2 / 1 / 2011$ & $3 / 2 / 2011$ & Não & Não & $2.091 .702 .000,00$ & $\mathrm{n} / \mathrm{d}$ \\
\hline 108 & SLC Agrícola S.A. & $\begin{array}{l}\text { Agricultura (Açúcar, } \\
\text { Álcool e Cana) }\end{array}$ & $6 / 3 / 1977$ & $6 / 12 / 2007$ & $15 / 6 / 2007$ & Não & Não & $1.993 .623 .363,54$ & $\mathrm{n} / \mathrm{d}$ \\
\hline
\end{tabular}

\footnotetext{
${ }^{78}$ Dado referente ao primeiro trimestre de 2012, posto que a companhia em questão não divulgou Formulário de Referência para o ano de 2013 , antes da data de corte utilizada para a elaboração do presente estudo (31 de maio de 2013).
} 
Tabela 1 - Perfil das Companhias Listadas no Novo Mercado ${ }^{1}$

\begin{tabular}{|c|c|c|c|c|c|c|c|c|c|}
\hline$\#$ & Denominação & $\begin{array}{c}\text { Setor de } \\
\text { Atividade }^{70}\end{array}$ & $\begin{array}{c}\text { Data da } \\
\text { Constituição }^{71}\end{array}$ & $\begin{array}{l}\text { Data do } \\
\text { Registro } \\
\text { CVM }^{72}\end{array}$ & $\begin{array}{c}\text { Data da } \\
\text { Listagem } \\
\mathbf{N M}^{73}\end{array}$ & $\begin{array}{c}\text { Integra } \\
\text { Ibovespa }^{74}\end{array}$ & $\begin{array}{l}\text { Integra } \\
\text { IBrX }^{75}\end{array}$ & \begin{tabular}{|c} 
Patrimônio Líquido \\
Consolidado em \\
$31 / 12 / 2012$ \\
$(\mathrm{em} \mathrm{R} \$)^{76}$
\end{tabular} & $\begin{array}{c}\text { Valor de Mercado } \\
\text { em Dez./2013 } \\
(\mathbf{R} \$)^{77}\end{array}$ \\
\hline 109 & Smiles S.A. & $\begin{array}{l}\text { Comércio (Atacado e } \\
\text { Varejo) }\end{array}$ & $6 / 10 / 2012$ & $25 / 4 / 2013$ & $29 / 4 / 2013$ & Não & Não & 100,00 & $\mathrm{n} / \mathrm{d}$ \\
\hline 110 & $\begin{array}{l}\text { Springs Global } \\
\text { Participações S.A. }\end{array}$ & Têxtil e Vestuário & $24 / 11 / 2005$ & $25 / 7 / 2007$ & $27 / 7 / 2007$ & Não & Não & $1.217 .533 .000,00$ & $\mathrm{n} / \mathrm{d}$ \\
\hline 111 & T4F Entretenimento S.A. & Brinquedos e Lazer & $18 / 11 / 1998$ & $4 / 11 / 2011$ & $13 / 4 / 2011$ & Não & Não & $354.442 .507,25$ & $\mathrm{n} / \mathrm{d}$ \\
\hline 112 & Tarpon Investimentos S.A. & $\begin{array}{l}\text { Intermediação } \\
\text { Financeira }\end{array}$ & $19 / 7 / 2002$ & $21 / 5 / 2009$ & $26 / 5 / 2009$ & Não & Não & $25.518 .000,00$ & $\mathrm{n} / \mathrm{d}$ \\
\hline 113 & Technos S.A. & $\begin{array}{l}\text { Comércio (Atacado e } \\
\text { Varejo) }\end{array}$ & $21 / 11 / 2007$ & $28 / 6 / 2011$ & $1 \stackrel{\circ}{\circ} / 2011$ & Não & Não & $407.784 .000,00$ & $\mathrm{n} / \mathrm{d}$ \\
\hline 114 & Tecnisa S.A. & $\begin{array}{l}\text { Construção Civil, Mat. } \\
\text { Constr. e Decoração }\end{array}$ & $22 / 5 / 2006$ & $1 \stackrel{\mathrm{o}}{9} / 9 / 2007$ & $1 \stackrel{\mathrm{o}}{2} / 2 / 2007$ & Não & Não & $1.433 .298 .000,00$ & $\mathrm{n} / \mathrm{d}$ \\
\hline 115 & $\begin{array}{l}\text { Tegma Gestão Logística } \\
\text { S.A. }\end{array}$ & $\begin{array}{l}\text { Serviços Transporte e } \\
\text { Logística }\end{array}$ & $1 \%$ o $/ 5 / 1998$ & $28 / 6 / 2007$ & $3 / 7 / 2007$ & Não & Não & $424.064 .000,00$ & $\mathrm{n} / \mathrm{d}$ \\
\hline 116 & Tempo Participações S.A. & Serviços médicos & $1 \%$ o $/ 1 / 2006$ & $1 \stackrel{\mathrm{o}}{4} / 2006$ & $19 / 12 / 2007$ & Não & Não & $279.319,00$ & $\mathrm{n} / \mathrm{d}$ \\
\hline 117 & Tereos Internacional S.A. & Alimentos & $2 / 2 / 2010$ & $8 / 11 / 2010$ & $13 / 8 / 2010$ & Não & Não & $3.627 .000 .000,00$ & $\mathrm{n} / \mathrm{d}$ \\
\hline 118 & Tim Participações S.A. & Telecomunicações & $22 / 5 / 1998$ & 19/8/1999 & $3 / 8 / 2011$ & Sim & Sim & $13.832 .870 .000,00$ & $\mathrm{n} / \mathrm{d}$ \\
\hline 119 & Totvs S.A. & $\begin{array}{l}\text { Comunicação e } \\
\text { Informática }\end{array}$ & $13 / 12 / 1983$ & $3 / 7 / 2006$ & $9 / 3 / 2006$ & Não & Não & $913.145 .622,80$ & $6.041 .742 .940,00$ \\
\hline 120 & $\begin{array}{l}\text { TPI - Triunfo Part. e } \\
\text { Investimentos S.A. }\end{array}$ & $\begin{array}{l}\text { Serviços Transporte e } \\
\text { Logística }\end{array}$ & $1 / 11 / 1999$ & $12 / 5 / 2002$ & $23 / 7 / 2007$ & Não & Não & $1.843 .747,00$ & $\mathrm{n} / \mathrm{d}$ \\
\hline 121 & Tractebel Energia S.A. & Energia Elétrica & 29/1/1998 & $28 / 5 / 1998$ & $16 / 11 / 2005$ & Sim & Sim & $5.462 .840 .480,90$ & $23.459 .554 .380,00$ \\
\hline 122 & Trisul S.A. & $\begin{array}{l}\text { Construção Civil, Mat. } \\
\text { Constr. e Decoração }\end{array}$ & $24 / 4 / 2007$ & $10 / 10 / 2007$ & $15 / 10 / 2007$ & Não & Não & $488.271 .000,00$ & $\mathrm{n} / \mathrm{d}$ \\
\hline
\end{tabular}


Tabela 1 - Perfil das Companhias Listadas no Novo Mercado ${ }^{1}$

\begin{tabular}{|c|c|c|c|c|c|c|c|c|c|}
\hline$\#$ & Denominação & $\begin{array}{c}\text { Setor de } \\
\text { Atividade }^{70}\end{array}$ & \begin{tabular}{c|} 
Data da \\
Constituiçãao $^{71}$
\end{tabular} & $\begin{array}{l}\text { Data do } \\
\text { Registro } \\
\text { CVM }^{72}\end{array}$ & $\begin{array}{l}\text { Data da } \\
\text { Listagem } \\
\mathbf{N M}^{73}\end{array}$ & \begin{tabular}{|l} 
Integra \\
Ibovespa $^{74}$
\end{tabular} & $\begin{array}{l}\text { Integra } \\
\mathrm{IBrX}^{75}\end{array}$ & $\begin{array}{c}\text { Patrimônio Líquido } \\
\text { Consolidado em } \\
31 / 12 / 2012 \\
(\text { em R\$) }\end{array}$ & $\begin{array}{c}\text { Valor de Mercado } \\
\text { em Dez./2013 } \\
(\mathbf{R} \$)^{77}\end{array}$ \\
\hline 123 & Ultrapar Participações S.A. & $\begin{array}{l}\text { Comércio (Atacado e } \\
\text { Varejo) }\end{array}$ & 20/12/1953 & 27/9/1999 & $18 / 8 / 2011$ & Sim & Sim & $6.015 .736 .000,00$ & $\mathrm{n} / \mathrm{d}$ \\
\hline 124 & $\begin{array}{l}\text { Unicasa Indústria de } \\
\text { Móveis S.A. }\end{array}$ & $\begin{array}{l}\text { Construção Civil, Mat. } \\
\text { Constr. e Decoração }\end{array}$ & $9 / 2 / 1985$ & $25 / 4 / 2012$ & $27 / 4 / 2012$ & Não & Não & 222.129.597,95 & $\mathrm{n} / \mathrm{d}$ \\
\hline 125 & $\begin{array}{l}\text { Valid Soluções e Serv. de } \\
\text { Segurança em Meios de } \\
\text { Pagamento e Identificação. } \\
\text { S.A. }\end{array}$ & Gráficas e Editoras & $13 / 5 / 1957$ & $4 / 12 / 2006$ & $27 / 04 / 2006$ & Não & Não & $512.449 .000,00$ & $\mathrm{n} / \mathrm{d}$ \\
\hline 126 & Vanguarda Agro S.A. & $\begin{array}{l}\text { Agricultura (Açúcar, } \\
\text { Álcool e Cana) }\end{array}$ & $18 / 7 / 2003$ & $11 / 9 / 2006$ & $26 / 11 / 2006$ & Não & Não & $1.490 .321 .468,44$ & $1.328 .862 .800,00$ \\
\hline 127 & Vigor Alimentos S.A. & Alimentos & $1 \frac{\mathrm{o}}{3} / 2011$ & $4 / 2 / 2012$ & $22 / 6 / 2012$ & Não & Não & $1.224 .289 .859,86$ & $\mathrm{n} / \mathrm{d}$ \\
\hline 128 & $\begin{array}{l}\text { Viver Incorporadora e } \\
\text { Construtora S.A. }\end{array}$ & $\begin{array}{l}\text { Construção Civil, Mat. } \\
\text { Constr. e Decoração }\end{array}$ & $2 / 6 / 1992$ & $23 / 5 / 2007$ & $6 / 6 / 2007$ & Não & Não & $589.319 .000,00$ & $\mathrm{n} / \mathrm{d}$ \\
\hline 129 & Weg S.A. & $\begin{array}{l}\text { Máquinas, } \\
\text { Equipamentos, } \\
\text { Veículos e Peças }\end{array}$ & $30 / 6 / 1961$ & $2 / 9 / 1982$ & $22 / 6 / 2007$ & Não & Não & $4.060 .349 .000,00$ & $19.347 .400 .700,00$ \\
\hline
\end{tabular}


APÊNDICE B

Tabela 2 - Composição do Capital Social - Identificação de Controle

\begin{tabular}{|c|c|c|c|c|c|c|c|c|c|c|c|c|c|c|c|c|c|c|}
\hline \multirow[b]{3}{*}{ \# } & \multirow[b]{3}{*}{ Denominação } & \multicolumn{15}{|c|}{ PARTICIPAÇÃO DOS MAIORES ACIONISTAS } & \multirow[b]{3}{*}{$\begin{array}{l}\text { Total de } \\
\text { Ações } \\
(\%)\end{array}$} & \multirow[b]{3}{*}{$\begin{array}{c}\text { Total } \\
\text { Controle } \\
(\%)\end{array}$} \\
\hline & & \multicolumn{3}{|c|}{$1^{\mathbf{0}}$} & \multicolumn{3}{|c|}{$2^{\underline{0}}$} & \multicolumn{3}{|c|}{$3^{0}$} & \multicolumn{3}{|c|}{$4^{0}$} & \multicolumn{3}{|c|}{$5^{0}$} & & \\
\hline & & $\%$ & $\begin{array}{c}\text { Controle } \\
(15.1)\end{array}$ & $\begin{array}{l}\text { Sign. } \\
\text { Acordo } \\
(15.2)\end{array}$ & $\%$ & \begin{tabular}{|c|} 
Controle \\
$(15.1)$
\end{tabular} & \begin{tabular}{|c|} 
Sign. \\
Acordo \\
$(15.2)$
\end{tabular} & $\%$ & $\begin{array}{c}\text { Controle } \\
(15.1)\end{array}$ & \begin{tabular}{|c} 
Sign. \\
Acordo \\
$(15.2)$
\end{tabular} & $\%$ & $\begin{array}{r}\text { Controle } \\
(15.1)\end{array}$ & $\begin{array}{c}\text { Sign. } \\
\text { Acordo } \\
(15.2)\end{array}$ & $\%$ & $\begin{array}{c}\text { Controle } \\
(15.1)\end{array}$ & $\begin{array}{l}\text { Sign. } \\
\text { Acordo } \\
(15.2)\end{array}$ & & \\
\hline 1 & $\begin{array}{l}\text { Aliansce } \\
\text { Shopping } \\
\text { Centers S.A. }\end{array}$ & 28,030663 & $\operatorname{sim}$ & $\operatorname{sim}$ & 12,611563 & não & não & 9,375217 & $\operatorname{sim}$ & $\operatorname{sim}$ & 6,022115 & não & não & 5,681282 & não & não & 61,720840 & 37,405880 \\
\hline 2 & $\begin{array}{l}\text { ALL América } \\
\text { Latina Logística } \\
\text { S.A. }\end{array}$ & 12,104161 & $\operatorname{sim}$ & $\operatorname{sim}$ & 5,612877 & $\operatorname{sim}$ & $\operatorname{sim}$ & 5,089489 & não & não & 5,02115 & não & não & 4,944954 & $\operatorname{sim}$ & $\operatorname{sim}$ & 32,772631 & 22,661992 \\
\hline 3 & $\begin{array}{l}\text { Anhanguera } \\
\text { Educacional } \\
\text { Participações } \\
\text { S.A }\end{array}$ & 10,274981 & não & $\operatorname{sim}$ & 5,484600 & não & não & 5,077939 & não & não & $\mathrm{n} / \mathrm{a}$ & $\mathrm{n} / \mathrm{a}$ & $\mathrm{n} / \mathrm{a}$ & $\mathrm{n} / \mathrm{a}$ & $\mathrm{n} / \mathrm{a}$ & $\mathrm{n} / \mathrm{a}$ & 20,837520 & 0,000000 \\
\hline 4 & $\begin{array}{l}\text { Arezzo Indústria } \\
\text { e Comércio S.A. }\end{array}$ & 35,200000 & $\operatorname{sim}$ & não & 17,200000 & $\operatorname{sim}$ & não & 5,490000 & não & não & 5,030000 & não & não & $\mathrm{n} / \mathrm{a}$ & $\mathrm{n} / \mathrm{a}$ & $\mathrm{n} / \mathrm{a}$ & 62,920000 & 52,400000 \\
\hline 5 & Arteris S.A. & 60,000000 & $\operatorname{sim}$ & não & $\mathrm{n} / \mathrm{a}$ & $\mathrm{n} / \mathrm{a}$ & $\mathrm{n} / \mathrm{a}$ & $\mathrm{n} / \mathrm{a}$ & $\mathrm{n} / \mathrm{a}$ & $\mathrm{n} / \mathrm{a}$ & $\mathrm{n} / \mathrm{a}$ & $\mathrm{n} / \mathrm{a}$ & $\mathrm{n} / \mathrm{a}$ & $\mathrm{n} / \mathrm{a}$ & $\mathrm{n} / \mathrm{a}$ & $\mathrm{n} / \mathrm{a}$ & 60,000000 & 60,000000 \\
\hline 6 & Autometal S.A. & 74,763100 & $\operatorname{sim}$ & não & $\mathrm{n} / \mathrm{a}$ & $\mathrm{n} / \mathrm{a}$ & $\mathrm{n} / \mathrm{a}$ & $\mathrm{n} / \mathrm{a}$ & $\mathrm{n} / \mathrm{a}$ & $\mathrm{n} / \mathrm{a}$ & $\mathrm{n} / \mathrm{a}$ & $\mathrm{n} / \mathrm{a}$ & $\mathrm{n} / \mathrm{a}$ & $\mathrm{n} / \mathrm{a}$ & $\mathrm{n} / \mathrm{a}$ & $\mathrm{n} / \mathrm{a}$ & 74,763100 & 74,763100 \\
\hline 7 & $\begin{array}{l}\text { B2W - } \\
\text { Companhia } \\
\text { Digital }\end{array}$ & 62,723600 & $\operatorname{sim}$ & não & 8,591100 & não & não & 5,160600 & não & não & $\mathrm{n} / \mathrm{a}$ & $\mathrm{n} / \mathrm{a}$ & $\mathrm{n} / \mathrm{a}$ & $\mathrm{n} / \mathrm{a}$ & $\mathrm{n} / \mathrm{a}$ & $\mathrm{n} / \mathrm{a}$ & 76,475300 & 62,723600 \\
\hline 8 & $\begin{array}{l}\text { Banco do Brasil } \\
\text { S.A. }\end{array}$ & 50,725151 & $\mathrm{sm}$ & não & 10,383247 & não & não & 3,861567 & $\operatorname{sim}$ & não & 3,687546 & $\operatorname{sim}$ & não & 0,330382 & $\operatorname{sim}$ & não & 68,987893 & 58,604646 \\
\hline 9 & $\begin{array}{l}\text { BB Seguridade } \\
\text { Participações }\end{array}$ & 66,250000 & $\operatorname{sim}$ & não & $\mathrm{n} / \mathrm{a}$ & $\mathrm{n} / \mathrm{a}$ & $\mathrm{n} / \mathrm{a}$ & $\mathrm{n} / \mathrm{a}$ & $\mathrm{n} / \mathrm{a}$ & $\mathrm{n} / \mathrm{a}$ & $\mathrm{n} / \mathrm{a}$ & $\mathrm{n} / \mathrm{a}$ & $\mathrm{n} / \mathrm{a}$ & $\mathrm{n} / \mathrm{a}$ & $\mathrm{n} / \mathrm{a}$ & $\mathrm{n} / \mathrm{a}$ & 66,250000 & 66,250000 \\
\hline
\end{tabular}


Tabela 2 - Composição do Capital Social - Identificação de Controle

\begin{tabular}{|c|c|c|c|c|c|c|c|c|c|c|c|c|c|c|c|c|c|c|}
\hline \multirow[b]{3}{*}{$\#$} & \multirow[b]{3}{*}{ Denominação } & \multicolumn{15}{|c|}{ PARTICIPAÇÃO DOS MAIORES ACIONISTAS } & \multirow{3}{*}{$\begin{array}{c}\text { Total de } \\
\text { Ações } \\
(\%) \\
\end{array}$} & \multirow{3}{*}{$\begin{array}{c}\text { Total } \\
\text { Controle } \\
(\%)\end{array}$} \\
\hline & & \multicolumn{3}{|c|}{$\mathbf{1}^{\mathbf{0}}$} & \multicolumn{3}{|c|}{$2^{\underline{9}}$} & \multicolumn{3}{|c|}{$3^{\underline{0}}$} & \multicolumn{3}{|c|}{$4^{0}$} & \multicolumn{3}{|c|}{$5^{0}$} & & \\
\hline & & $\%$ & $\begin{array}{c}\text { Controle } \\
(15.1)\end{array}$ & $\frac{\text { Sign. }}{\text { Acordo }}$ & $\%$ & $\begin{array}{c}\text { Controle } \\
(15.1)\end{array}$ & \begin{tabular}{|l} 
Sign. \\
Acordo \\
$(15.2)$
\end{tabular} & $\%$ & $\begin{array}{c}\text { Controle } \\
(15.1)\end{array}$ & 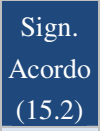 & $\%$ & \begin{tabular}{|c|} 
Controle \\
$(15.1)$
\end{tabular} & 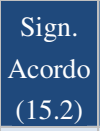 & $\%$ & $\begin{array}{c}\text { Controle } \\
(15.1)\end{array}$ & $\begin{array}{c}\text { Sign. } \\
\text { Acordo } \\
(15.2)\end{array}$ & & \\
\hline & S.A. & & & & & & & & & & & & & & & & & \\
\hline 10 & Bematech S.A. & 10,100000 & não & não & 8,840000 & não & não & 8,640000 & não & não & 7,390000 & não & não & 5,290000 & não & não & 40,260000 & 0,000000 \\
\hline 11 & $\begin{array}{l}\text { BHG S.A. - } \\
\text { Brazil } \\
\text { Hospitality } \\
\text { Group }\end{array}$ & 29,507800 & $\operatorname{sim}$ & não & 0,667900 & $\operatorname{sim}$ & não & $\mathrm{n} / \mathrm{a}$ & $\mathrm{n} / \mathrm{a}$ & $\mathrm{n} / \mathrm{a}$ & $\mathrm{n} / \mathrm{a}$ & $\mathrm{n} / \mathrm{a}$ & $\mathrm{n} / \mathrm{a}$ & $\mathrm{n} / \mathrm{a}$ & $\mathrm{n} / \mathrm{a}$ & $\mathrm{n} / \mathrm{a}$ & 30,175700 & 30,175700 \\
\hline 12 & Biosev S.A. & 49,777061 & $\operatorname{sim}$ & $\operatorname{sim}$ & 7,232273 & não & $\operatorname{sim}$ & 5,847975 & não & $\operatorname{sim}$ & 5,442532 & não & não & 4,31287 & $\operatorname{sim}$ & $\operatorname{sim}$ & 72,612711 & 54,089931 \\
\hline 13 & $\begin{array}{l}\text { BM\&Fbovespa } \\
\text { S.A. Bolsa } \\
\text { Valores Merc. } \\
\text { Fut. }\end{array}$ & 6,561100 & não & não & 5,291300 & não & não & 5,202200 & não & não & 5,105000 & não & não & $\mathrm{n} / \mathrm{a}$ & $\mathrm{n} / \mathrm{a}$ & $\mathrm{n} / \mathrm{a}$ & 22,159600 & 0,000000 \\
\hline 14 & $\begin{array}{l}\text { Brasilagro - Cia. } \\
\text { Bras. de Prop. } \\
\text { Agrícolas }\end{array}$ & 25,439386 & $\operatorname{sim}$ & não & 14,203713 & $\operatorname{sim}$ & não & 10,516857 & não & não & 5,283076 & não & não & 4,519328 & não & não & 59,962360 & 39,643099 \\
\hline 15 & $\begin{array}{l}\text { BR Malls } \\
\text { Participações } \\
\text { S.A. }\end{array}$ & 4,992784 & não & não & $\mathrm{n} / \mathrm{a}$ & $\mathrm{n} / \mathrm{a}$ & $\mathrm{n} / \mathrm{a}$ & $\mathrm{n} / \mathrm{a}$ & $\mathrm{n} / \mathrm{a}$ & $\mathrm{n} / \mathrm{a}$ & $\mathrm{n} / \mathrm{a}$ & $\mathrm{n} / \mathrm{a}$ & $\mathrm{n} / \mathrm{a}$ & $\mathrm{n} / \mathrm{a}$ & $\mathrm{n} / \mathrm{a}$ & $\mathrm{n} / \mathrm{a}$ & 4,992784 & 0,000000 \\
\hline 16 & $\begin{array}{l}\text { BR Properties } \\
\text { S.A. }\end{array}$ & 24,494500 & não & não & 6,861900 & não & não & 5,023000 & não & não & 4,696700 & não & não & 0,908000 & não & não & 41,984100 & 0,000000 \\
\hline 17 & $\begin{array}{l}\text { Brasil Brokers } \\
\text { Participações } \\
\text { S.A. }\end{array}$ & 10,047441 & não & não & 8,992759 & $\operatorname{sim}$ & $\operatorname{sim}$ & 8,453586 & não & não & 7,453383 & $\operatorname{sim}$ & $\operatorname{sim}$ & 6,472574 & não & não & 41,419743 & 16,446142 \\
\hline 18 & $\begin{array}{l}\text { Brasil Insurance } \\
\text { Particip. e } \\
\text { Administração } \\
\text { S.A. }\end{array}$ & 6,480000 & $\operatorname{sim}$ & $\operatorname{sim}$ & 5,870000 & não & não & 5,200000 & não & não & 1,510000 & não & não & $\mathrm{n} / \mathrm{a}$ & $\mathrm{n} / \mathrm{a}$ & $\mathrm{n} / \mathrm{a}$ & 19,060000 & 6,480000 \\
\hline 19 & $\begin{array}{l}\text { Brasil Pharma } \\
\text { S.A. }\end{array}$ & 15,284000 & não & não & 11,710000 & não & não & 8,459000 & não & não & 0,409000 & não & não & $\mathrm{n} / \mathrm{a}$ & $\mathrm{n} / \mathrm{a}$ & $\mathrm{n} / \mathrm{a}$ & 35,862000 & 0,000000 \\
\hline
\end{tabular}


Tabela 2 - Composição do Capital Social - Identificação de Controle

\begin{tabular}{|c|c|c|c|c|c|c|c|c|c|c|c|c|c|c|c|c|c|c|}
\hline \multirow[b]{3}{*}{$\#$} & \multirow[b]{3}{*}{ Denominação } & \multicolumn{15}{|c|}{ PARTICIPAÇÃO DOS MAIORES ACIONISTAS } & \multirow[b]{3}{*}{$\begin{array}{c}\text { Total de } \\
\text { Ações } \\
(\%) \\
\end{array}$} & \multirow[b]{3}{*}{$\begin{array}{c}\text { Total } \\
\text { Controle } \\
(\%)\end{array}$} \\
\hline & & \multicolumn{3}{|c|}{$\mathbf{1}^{\underline{0}}$} & \multicolumn{3}{|c|}{$2^{9}$} & \multicolumn{3}{|c|}{$3^{\underline{0}}$} & \multicolumn{3}{|c|}{$4^{0}$} & \multicolumn{3}{|c|}{$5^{0}$} & & \\
\hline & & $\%$ & $\begin{array}{c}\text { Controle } \\
(15.1)\end{array}$ & $\begin{array}{c}\text { Sign. } \\
\text { Acordo } \\
(15.2)\end{array}$ & $\%$ & \begin{tabular}{|c|} 
Controle \\
$(15.1)$
\end{tabular} & \begin{tabular}{|c|} 
Sign. \\
Acordo \\
$(15.2)$
\end{tabular} & $\%$ & $\begin{array}{c}\text { Controle } \\
(15.1)\end{array}$ & 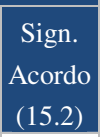 & $\%$ & \begin{tabular}{|c|} 
Controle \\
$(15.1)$
\end{tabular} & $\frac{\text { Sign. }}{\text { Acordo }}$ & $\%$ & \begin{tabular}{|} 
Controle \\
$(15.1)$
\end{tabular} & $\begin{array}{c}\text { Sign. } \\
\text { Acordo } \\
(15.2)\end{array}$ & & \\
\hline 20 & BRF S.A. & 12,200000 & não & não & 12,100000 & não & não & 8,020000 & não & não & 5,130000 & não & não & 2,870000 & não & não & 40,320000 & 0,000000 \\
\hline 21 & $\begin{array}{l}\text { Brookfield } \\
\text { Incorporações } \\
\text { S.A. }\end{array}$ & 38,530000 & $\operatorname{sim}$ & $\operatorname{sim}$ & 6,830000 & não & não & 5,120000 & $\operatorname{sim}$ & $\operatorname{sim}$ & 1,770000 & $\operatorname{sim}$ & $\operatorname{sim}$ & 1,350000 & $\operatorname{sim}$ & $\operatorname{sim}$ & 53,600000 & 46,770000 \\
\hline 22 & CCR S.A. & 16,610000 & $\operatorname{sim}$ & $\operatorname{sim}$ & 15,240000 & $\operatorname{sim}$ & $\operatorname{sim}$ & 11,930000 & $\operatorname{sim}$ & $\operatorname{sim}$ & 5,290000 & $\operatorname{sim}$ & $\operatorname{sim}$ & 1,760000 & $\operatorname{sim}$ & $\operatorname{sim}$ & 50,830000 & 50,830000 \\
\hline 23 & $\begin{array}{l}\text { CCX Carvão da } \\
\text { Colômbia S.A. }\end{array}$ & 56,280000 & $\operatorname{sim}$ & não & 11,720000 & não & não & 8,000000 & não & não & 3,960000 & $\operatorname{sim}$ & não & 1,000000 & $\operatorname{sim}$ & não & 80,960000 & 61,240000 \\
\hline 24 & $\begin{array}{l}\text { CETIP S.A. - } \\
\text { Mercados } \\
\text { Organizados }\end{array}$ & 12,180000 & não & não & 7,660000 & não & não & 5,530000 & não & não & $\mathrm{n} / \mathrm{a}$ & $\mathrm{n} / \mathrm{a}$ & $\mathrm{n} / \mathrm{a}$ & $\mathrm{n} / \mathrm{a}$ & $\mathrm{n} / \mathrm{a}$ & $\mathrm{n} / \mathrm{a}$ & 25,370000 & 0,000000 \\
\hline 25 & Cia Hering & 7,270000 & não & não & 7,150000 & não & não & 5,420000 & não & não & 5,110000 & não & não & 5,040000 & não & não & 19,840000 & 0,000000 \\
\hline 26 & $\begin{array}{l}\text { Cia Providência } \\
\text { Indústria e } \\
\text { Comércio }\end{array}$ & 17,431291 & $\operatorname{sim}$ & $\operatorname{sim}$ & 12,586557 & $\operatorname{sim}$ & $\operatorname{sim}$ & 11,766122 & $\operatorname{sim}$ & $\operatorname{sim}$ & 7,844082 & $\operatorname{sim}$ & $\operatorname{sim}$ & 7,322821 & $\operatorname{sim}$ & $\operatorname{sim}$ & 56,950873 & 56,950873 \\
\hline 27 & $\begin{array}{l}\text { Cia Saneamento } \\
\text { Básico Est. São } \\
\text { Paulo }\end{array}$ & 50,260000 & $\operatorname{sim}$ & não & $\mathrm{n} / \mathrm{a}$ & $\mathrm{n} / \mathrm{a}$ & $\mathrm{n} / \mathrm{a}$ & $\mathrm{n} / \mathrm{a}$ & $\mathrm{n} / \mathrm{a}$ & $\mathrm{n} / \mathrm{a}$ & $\mathrm{n} / \mathrm{a}$ & $\mathrm{n} / \mathrm{a}$ & $\mathrm{n} / \mathrm{a}$ & $\mathrm{n} / \mathrm{a}$ & $\mathrm{n} / \mathrm{a}$ & $\mathrm{n} / \mathrm{a}$ & 50,260000 & 50,260000 \\
\hline 28 & $\begin{array}{l}\text { Cia Saneamento } \\
\text { de Minas Gerais } \\
\text { - COPASA MG }\end{array}$ & 51,125169 & $\operatorname{sim}$ & não & 5,679491 & não & não & 5,024630 & não & não & 4,835218 & não & não & $\mathrm{n} / \mathrm{a}$ & $\mathrm{n} / \mathrm{a}$ & $\mathrm{n} / \mathrm{a}$ & 66,664508 & 51,125169 \\
\hline 29 & Cielo S.A. & 28,648300 & $\operatorname{sim}$ & $\operatorname{sim}$ & 28,648200 & $\operatorname{sim}$ & $\operatorname{sim}$ & 9,964100 & não & não & $\mathrm{n} / \mathrm{a}$ & $\mathrm{n} / \mathrm{a}$ & $\mathrm{n} / \mathrm{a}$ & $\mathrm{n} / \mathrm{a}$ & $\mathrm{n} / \mathrm{a}$ & $\mathrm{n} / \mathrm{a}$ & 67,260600 & 57,296500 \\
\hline 30 & $\begin{array}{l}\text { Companhia de } \\
\text { Locação das } \\
\text { Américas }\end{array}$ & 23,510000 & $\operatorname{sim}$ & $\operatorname{sim}$ & 23,510000 & $\operatorname{sim}$ & $\operatorname{sim}$ & 7,730000 & não & não & 6,230000 & não & não & $\mathrm{n} / \mathrm{a}$ & $\mathrm{n} / \mathrm{a}$ & $\mathrm{n} / \mathrm{a}$ & 60,980000 & 47,020000 \\
\hline 31 & $\begin{array}{l}\text { Cosan S.A. } \\
\text { Indústria e } \\
\text { Comércio }\end{array}$ & 59,330208 & $\operatorname{sim}$ & $\operatorname{sim}$ & 4,615404 & não & $\operatorname{sim}$ & 2,871294 & não & $\operatorname{sim}$ & 2,684264 & não & $\operatorname{sim}$ & 2,662828 & Sim & não & 72,163998 & 61,993036 \\
\hline
\end{tabular}


Tabela 2 - Composição do Capital Social - Identificação de Controle

\begin{tabular}{|c|c|c|c|c|c|c|c|c|c|c|c|c|c|c|c|c|c|c|}
\hline \multirow[b]{3}{*}{$\#$} & \multirow[b]{3}{*}{ Denominação } & \multicolumn{15}{|c|}{ PARTICIPAÇÃO DOS MAIORES ACIONISTAS } & \multirow{3}{*}{$\begin{array}{c}\text { Total de } \\
\text { Ações } \\
(\%) \\
\end{array}$} & \multirow{3}{*}{$\begin{array}{c}\text { Total } \\
\text { Controle } \\
(\%)\end{array}$} \\
\hline & & \multicolumn{3}{|c|}{$1^{\underline{9}}$} & \multicolumn{3}{|c|}{$2^{\underline{9}}$} & \multicolumn{3}{|c|}{$3^{\mathbf{0}}$} & \multicolumn{3}{|c|}{$4^{0}$} & \multicolumn{3}{|c|}{$5^{0}$} & & \\
\hline & & $\%$ & $\begin{array}{c}\text { Controle } \\
(15.1)\end{array}$ & $\begin{array}{c}\text { Sign. } \\
\text { Acordo } \\
(15.2)\end{array}$ & $\%$ & \begin{tabular}{|c|} 
Controle \\
$(15.1)$ \\
\end{tabular} & $\frac{\text { Sign. }}{\text { Acordo }}$ & $\%$ & $\begin{array}{c}\overline{\text { Controle }} \\
(15.1)\end{array}$ & 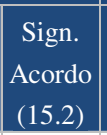 & $\%$ & $\begin{array}{c}\text { Controle } \\
(15.1)\end{array}$ & \begin{tabular}{|l} 
Sign. \\
Acordo \\
$(15.2)$
\end{tabular} & $\%$ & $\begin{array}{c}\text { Controle } \\
(15.1)\end{array}$ & $\begin{array}{c}\text { Sign. } \\
\text { Acordo } \\
(15.2)\end{array}$ & & \\
\hline 32 & $\begin{array}{l}\text { CPFL Energia } \\
\text { S.A. }\end{array}$ & 29,990000 & $\operatorname{sim}$ & $\operatorname{sim}$ & 24,330000 & $\operatorname{sim}$ & $\operatorname{sim}$ & 14,220000 & $\operatorname{sim}$ & $\operatorname{sim}$ & 8,420000 & não & não & 0,660000 & Sim & $\operatorname{sim}$ & 77,620000 & 69,200000 \\
\hline 33 & $\begin{array}{l}\text { CR2 } \\
\text { Empreendimento } \\
\text { s Imobiliários } \\
\text { S.A. }\end{array}$ & 19,635891 & não & não & 16,381562 & não & não & 16,221724 & não & não & 10,205837 & não & não & 8,766110 & Não & não & 61,005287 & 0,000000 \\
\hline 34 & Cremer S.A. & 51,260000 & $\operatorname{sim}$ & não & 10,110000 & não & não & 5,220000 & não & não & 5,130000 & não & não & $\mathrm{n} / \mathrm{a}$ & $\mathrm{n} / \mathrm{a}$ & $\mathrm{n} / \mathrm{a}$ & 71,720000 & 51,260000 \\
\hline 35 & $\begin{array}{l}\text { CSU Cardsystem } \\
\text { S.A. }\end{array}$ & 39,407999 & $\operatorname{sim}$ & não & 15,471431 & $\operatorname{sim}$ & não & 11,288355 & não & não & 6,083829 & não & não & 1,571042 & Sim & não & 73,822656 & 56,450472 \\
\hline 36 & $\begin{array}{l}\text { Cyrela Brazil } \\
\text { Realty S.A. } \\
\text { Empreend. Part. }\end{array}$ & 23,551374 & $\operatorname{sim}$ & $\operatorname{sim}$ & 7,137658 & não & não & 5,383517 & não & não & 5,256101 & $\operatorname{sim}$ & $\operatorname{sim}$ & 5,076506 & Não & não & 46,405156 & 28,807475 \\
\hline 37 & $\begin{array}{l}\text { Cyrela } \\
\text { Commercial } \\
\text { Properties S.A. } \\
\text { Empr. Part. }\end{array}$ & 37,949900 & $\operatorname{sim}$ & não & 25,867500 & não & não & 12,382000 & não & não & 5,277100 & $\operatorname{sim}$ & não & 2,597500 & Não & não & 84,074000 & 43,227000 \\
\hline 38 & $\begin{array}{l}\text { Diagnósticos da } \\
\text { América S.A. }\end{array}$ & 12,028467 & não & não & 11,556740 & não & não & 10,100223 & não & não & 10,000000 & não & não & 5,012171 & Não & não & 48,697601 & 0,000000 \\
\hline 39 & $\begin{array}{l}\text { Direcional } \\
\text { Engenharia S.A. }\end{array}$ & 40,289729 & $\operatorname{sim}$ & não & 6,439202 & não & não & 5,854289 & não & não & $\mathrm{n} / \mathrm{a}$ & $\mathrm{n} / \mathrm{a}$ & $\mathrm{n} / \mathrm{a}$ & $\mathrm{n} / \mathrm{a}$ & $\mathrm{n} / \mathrm{a}$ & $\mathrm{n} / \mathrm{a}$ & 52,583220 & 40,289729 \\
\hline 40 & Duratex S.A. & 35,401634 & $\operatorname{sim}$ & $\operatorname{sim}$ & 14,691558 & $\operatorname{sim}$ & $\operatorname{sim}$ & 1,927083 & $\operatorname{sim}$ & $\operatorname{sim}$ & 1,358422 & $\operatorname{sim}$ & $\operatorname{sim}$ & 1,146366 & Sim & $\operatorname{sim}$ & 54,525063 & 54,525063 \\
\hline 41 & $\begin{array}{l}\text { Ecorodovias } \\
\text { Infraestrutura e } \\
\text { Logística S.A. }\end{array}$ & 63,988691 & $\operatorname{sim}$ & não & 27,173094 & não & não & 8,744108 & não & não & $\mathrm{n} / \mathrm{a}$ & $\mathrm{n} / \mathrm{a}$ & $\mathrm{n} / \mathrm{a}$ & $\mathrm{n} / \mathrm{a}$ & $\mathrm{n} / \mathrm{a}$ & $\mathrm{n} / \mathrm{a}$ & 99,905893 & 63,988691 \\
\hline 42 & $\begin{array}{l}\text { EDP - Energias } \\
\text { do Brasil S.A. }\end{array}$ & 35,302206 & $\operatorname{sim}$ & não & 15,697794 & $\operatorname{sim}$ & não & 5,200982 & não & não & 0,000010 & não & não & $\mathrm{n} / \mathrm{a}$ & $\mathrm{n} / \mathrm{a}$ & $\mathrm{n} / \mathrm{a}$ & 56,200992 & 51,000000 \\
\hline 43 & Embraer S.A. & 8,850000 & não & não & 7,860000 & não & não & 7,630000 & não & não & 5,370000 & não & não & $\mathrm{n} / \mathrm{a}$ & $\mathrm{n} / \mathrm{a}$ & $\mathrm{n} / \mathrm{a}$ & 29,710000 & 0,000000 \\
\hline
\end{tabular}


Tabela 2 - Composição do Capital Social - Identificação de Controle

\begin{tabular}{|c|c|c|c|c|c|c|c|c|c|c|c|c|c|c|c|c|c|c|}
\hline \multirow[b]{3}{*}{$\#$} & \multirow[b]{3}{*}{ Denominação } & \multicolumn{15}{|c|}{ PARTICIPAÇÃO DOS MAIORES ACIONISTAS } & \multirow[b]{3}{*}{$\begin{array}{c}\text { Total de } \\
\text { Ações } \\
(\%) \\
\end{array}$} & \multirow{3}{*}{$\begin{array}{c}\text { Total } \\
\text { Controle } \\
(\%)\end{array}$} \\
\hline & & \multicolumn{3}{|c|}{$\mathbf{1}^{\underline{0}}$} & \multicolumn{3}{|c|}{$2^{\underline{9}}$} & \multicolumn{3}{|c|}{$3^{0}$} & \multicolumn{3}{|c|}{$4^{0}$} & \multicolumn{3}{|c|}{$5^{0}$} & & \\
\hline & & $\%$ & $\begin{array}{c}\text { Controle } \\
(15.1)\end{array}$ & $\frac{\text { Sign. }}{\text { Acordo }}$ & $\%$ & \begin{tabular}{|c|} 
Controle \\
$(15.1)$
\end{tabular} & \begin{tabular}{|l} 
Sign. \\
Acordo \\
$(15.2)$
\end{tabular} & $\%$ & $\begin{array}{c}\text { Controle } \\
(15.1)\end{array}$ & 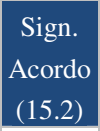 & $\%$ & \begin{tabular}{|c|} 
Controle \\
$(15.1)$
\end{tabular} & 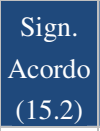 & $\%$ & $\begin{array}{c}\text { Controle } \\
(15.1)\end{array}$ & $\begin{array}{c}\text { Sign. } \\
\text { Acordo } \\
(15.2)\end{array}$ & & \\
\hline 44 & $\begin{array}{l}\text { Equatorial } \\
\text { Energia S.A. }\end{array}$ & 22,940000 & $\operatorname{sim}$ & não & 15,590000 & não & não & 5,350000 & não & não & 5,080000 & não & não & 0,120000 & não & não & 49,080000 & 22,940000 \\
\hline 45 & $\begin{array}{l}\text { Estácio } \\
\text { Participações } \\
\text { S.A. }\end{array}$ & 12,026076 & não & não & 9,839178 & não & não & 5,021332 & não & não & 4,347573 & não & não & 4,337512 & não & não & 35,571671 & 0,000000 \\
\hline 46 & Eternit S.A. & 15,251397 & não & não & 13,564246 & não & não & 6,703911 & não & não & $\mathrm{n} / \mathrm{a}$ & $\mathrm{n} / \mathrm{a}$ & $\mathrm{n} / \mathrm{a}$ & $\mathrm{n} / \mathrm{a}$ & $\mathrm{n} / \mathrm{a}$ & $\mathrm{n} / \mathrm{a}$ & 35,519554 & 0,000000 \\
\hline 47 & $\begin{array}{l}\text { Even } \\
\text { Construtora e } \\
\text { Incorporadora } \\
\text { S.A. }\end{array}$ & 5,160000 & não & não & 5,100000 & não & não & $\mathrm{n} / \mathrm{a}$ & $\mathrm{n} / \mathrm{a}$ & $\mathrm{n} / \mathrm{a}$ & $\mathrm{n} / \mathrm{a}$ & $\mathrm{n} / \mathrm{a}$ & $\mathrm{n} / \mathrm{a}$ & $\mathrm{n} / \mathrm{a}$ & $\mathrm{n} / \mathrm{a}$ & $\mathrm{n} / \mathrm{a}$ & 10,260000 & 0,000000 \\
\hline 48 & $\begin{array}{l}\text { EZ TEC } \\
\text { Empreend. e } \\
\text { Participações } \\
\text { S.A. }\end{array}$ & 31,560000 & $\operatorname{sim}$ & $\operatorname{sim}$ & 6,470000 & $\operatorname{sim}$ & $\operatorname{sim}$ & 5,590000 & $\operatorname{sim}$ & $\operatorname{sim}$ & 5,300000 & $\operatorname{sim}$ & $\operatorname{sim}$ & 4,410000 & $\operatorname{sim}$ & $\operatorname{sim}$ & 53,330000 & 53,330000 \\
\hline 49 & $\begin{array}{l}\text { Fertilizantes } \\
\text { Heringer S.A. }\end{array}$ & 51,545655 & $\operatorname{sim}$ & $\operatorname{sim}$ & 8,142031 & $\operatorname{sim}$ & $\operatorname{sim}$ & 8,073046 & $\operatorname{sim}$ & $\operatorname{sim}$ & $\mathrm{n} / \mathrm{a}$ & $\mathrm{n} / \mathrm{a}$ & $\mathrm{n} / \mathrm{a}$ & $\mathrm{n} / \mathrm{a}$ & $\mathrm{n} / \mathrm{a}$ & $\mathrm{n} / \mathrm{a}$ & 67,760732 & 67,760732 \\
\hline 50 & $\begin{array}{l}\text { Fibria Celulose } \\
\text { S.A. }\end{array}$ & 30,382000 & $\operatorname{sim}$ & $\operatorname{sim}$ & 29,421000 & $\operatorname{sim}$ & sim & 5,175000 & não & não & 5,010000 & não & não & $\mathrm{n} / \mathrm{a}$ & $\mathrm{n} / \mathrm{a}$ & $\mathrm{n} / \mathrm{a}$ & 69,988000 & 59,803000 \\
\hline 51 & Fleury S.A. & 52,700000 & $\operatorname{sim}$ & $\operatorname{sim}$ & 8,370000 & não & $\operatorname{sim}$ & $\mathrm{n} / \mathrm{a}$ & $\mathrm{n} / \mathrm{a}$ & $\mathrm{n} / \mathrm{a}$ & $\mathrm{n} / \mathrm{a}$ & $\mathrm{n} / \mathrm{a}$ & $\mathrm{n} / \mathrm{a}$ & $\mathrm{n} / \mathrm{a}$ & $\mathrm{n} / \mathrm{a}$ & $\mathrm{n} / \mathrm{a}$ & 61,070000 & 52,700000 \\
\hline 52 & Gafisa S.A. & 5,480000 & não & não & 5,210000 & não & não & 0,320000 & não & não & 0,090000 & não & não & $\mathrm{n} / \mathrm{a}$ & $\mathrm{n} / \mathrm{a}$ & $\mathrm{n} / \mathrm{a}$ & 11,100000 & 0,000000 \\
\hline 53 & $\begin{array}{l}\text { General } \\
\text { Shopping Brasil } \\
\text { S.A. }\end{array}$ & 59,411550 & $\operatorname{sim}$ & não & 10,024841 & não & não & $\mathrm{n} / \mathrm{a}$ & $\mathrm{n} / \mathrm{a}$ & $\mathrm{n} / \mathrm{a}$ & $\mathrm{n} / \mathrm{a}$ & $\mathrm{n} / \mathrm{a}$ & $\mathrm{n} / \mathrm{a}$ & $\mathrm{n} / \mathrm{a}$ & $\mathrm{n} / \mathrm{a}$ & $\mathrm{n} / \mathrm{a}$ & 69,436391 & 59,411550 \\
\hline 54 & Grendene S.A. & 29,928172 & $\operatorname{sim}$ & $\operatorname{sim}$ & 23,942538 & $\operatorname{sim}$ & sim & 20,051875 & sim & $\operatorname{sim}$ & $\mathrm{n} / \mathrm{a}$ & $\mathrm{n} / \mathrm{a}$ & $\mathrm{n} / \mathrm{a}$ & $\mathrm{n} / \mathrm{a}$ & $\mathrm{n} / \mathrm{a}$ & $\mathrm{n} / \mathrm{a}$ & 73,922585 & 73,922585 \\
\hline 55 & $\begin{array}{l}\text { Helbor } \\
\text { Empreendimen- } \\
\text { tos S.A. }\end{array}$ & 38,630000 & $\operatorname{sim}$ & não & 9,960000 & não & não & 8,490000 & sim & não & 5,290000 & sim & não & $\mathrm{n} / \mathrm{a}$ & $\mathrm{n} / \mathrm{a}$ & $\mathrm{n} / \mathrm{a}$ & 62,370000 & 52,410000 \\
\hline
\end{tabular}


Tabela 2 - Composição do Capital Social - Identificação de Controle

\begin{tabular}{|c|c|c|c|c|c|c|c|c|c|c|c|c|c|c|c|c|c|c|}
\hline \multirow[b]{3}{*}{$\#$} & \multirow[b]{3}{*}{ Denominação } & \multicolumn{15}{|c|}{ PARTICIPAÇÃO DOS MAIORES ACIONISTAS } & \multirow[b]{3}{*}{$\begin{array}{c}\text { Total de } \\
\text { Ações } \\
(\%) \\
\end{array}$} & \multirow{3}{*}{$\begin{array}{c}\text { Total } \\
\text { Controle } \\
(\%)\end{array}$} \\
\hline & & \multicolumn{3}{|c|}{$1^{\mathbf{0}}$} & \multicolumn{3}{|c|}{$2^{\underline{9}}$} & \multicolumn{3}{|c|}{$3^{0}$} & \multicolumn{3}{|c|}{$4^{0}$} & \multicolumn{3}{|c|}{$5^{0}$} & & \\
\hline & & $\%$ & $\begin{array}{c}\text { Controle } \\
(15.1)\end{array}$ & $\begin{array}{c}\text { Sign. } \\
\text { Acordo } \\
(15.2)\end{array}$ & $\%$ & \begin{tabular}{|c|} 
Controle \\
$(15.1)$
\end{tabular} & \begin{tabular}{|l} 
Sign. \\
Acordo \\
$(15.2)$
\end{tabular} & $\%$ & $\begin{array}{c}\text { Controle } \\
(15.1)\end{array}$ & \begin{tabular}{|l} 
Sign. \\
Acordo \\
$(15.2)$
\end{tabular} & $\%$ & $\begin{array}{c}\text { Controle } \\
(15.1)\end{array}$ & 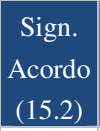 & $\%$ & $\begin{array}{c}\text { Controle } \\
(15.1)\end{array}$ & $\begin{array}{c}\text { Sign. } \\
\text { Acordo } \\
(15.2)\end{array}$ & & \\
\hline 56 & $\begin{array}{l}\text { HRT } \\
\text { Participações em } \\
\text { Petróleo S.A. }\end{array}$ & 13,006192 & não & não & 7,065336 & não & não & $\mathrm{n} / \mathrm{a}$ & $\mathrm{n} / \mathrm{a}$ & $\mathrm{n} / \mathrm{a}$ & $\mathrm{n} / \mathrm{a}$ & $\mathrm{n} / \mathrm{a}$ & $\mathrm{n} / \mathrm{a}$ & $\mathrm{n} / \mathrm{a}$ & $\mathrm{n} / \mathrm{a}$ & $\mathrm{n} / \mathrm{a}$ & 20,071528 & 0,000000 \\
\hline 57 & $\begin{array}{l}\text { Hypermarcas } \\
\text { S.A. }\end{array}$ & 20,138641 & $\operatorname{sim}$ & $\operatorname{sim}$ & 14,771660 & $\operatorname{sim}$ & $\operatorname{sim}$ & 5,480273 & $\operatorname{sim}$ & $\operatorname{sim}$ & 5,463636 & não & não & 0,241015 & $\operatorname{sim}$ & $\operatorname{sim}$ & 46,095225 & 40,631589 \\
\hline 58 & Ideiasnet S.A. & 14,995900 & não & não & 14,771300 & não & não & 10,288500 & não & não & 6,852000 & não & não & 5,122700 & não & não & 52,030400 & 0,000000 \\
\hline 59 & $\begin{array}{l}\text { Iguatemi } \\
\text { Empresa de } \\
\text { Shopping } \\
\text { Centers S.A }\end{array}$ & 56,036398 & $\operatorname{sim}$ & não & 10,326915 & não & não & 6,949487 & não & não & 0,909242 & $\operatorname{sim}$ & não & 0,101446 & $\operatorname{sim}$ & não & 74,323488 & 57,047086 \\
\hline 60 & $\begin{array}{l}\text { Indústrias Romi } \\
\text { S.A. }\end{array}$ & 37,858300 & $\operatorname{sim}$ & $\operatorname{sim}$ & 9,777600 & não & não & 7,703600 & não & não & 2,087000 & não & não & 1,959700 & não & não & 59,386200 & 37,858300 \\
\hline 61 & $\begin{array}{l}\text { International } \\
\text { Meal Company } \\
\text { Holdings S.A. }\end{array}$ & 39,750000 & $\operatorname{sim}$ & não & $\mathrm{n} / \mathrm{a}$ & $\mathrm{n} / \mathrm{a}$ & $\mathrm{n} / \mathrm{a}$ & $\mathrm{n} / \mathrm{a}$ & $\mathrm{n} / \mathrm{a}$ & $\mathrm{n} / \mathrm{a}$ & $\mathrm{n} / \mathrm{a}$ & $\mathrm{n} / \mathrm{a}$ & $\mathrm{n} / \mathrm{a}$ & $\mathrm{n} / \mathrm{a}$ & $\mathrm{n} / \mathrm{a}$ & $\mathrm{n} / \mathrm{a}$ & 39,750000 & 39,750000 \\
\hline 62 & $\begin{array}{l}\text { Iochpe Maxion } \\
\text { S.A. }\end{array}$ & 6,766869 & $\operatorname{sim}$ & $\operatorname{sim}$ & 5,571381 & não & não & 5,536512 & $\operatorname{sim}$ & $\operatorname{sim}$ & 5,231790 & não & não & 5,002382 & não & não & 28,108934 & 12,303381 \\
\hline 63 & JBS S.A. & 42,661000 & $\operatorname{sim}$ & sim & 19,853500 & não & sim & 10,068900 & não & não & 3,491400 & não & não & 0,937200 & não & $\operatorname{sim}$ & 77,012000 & 43,598200 \\
\hline 64 & $\begin{array}{l}\text { JHSF } \\
\text { Participações } \\
\text { S.A. }\end{array}$ & 62,960000 & $\operatorname{sim}$ & não & 5,640000 & $\operatorname{sim}$ & não & 5,640000 & não & não & 5,540000 & não & não & $\mathrm{n} / \mathrm{a}$ & $\mathrm{n} / \mathrm{a}$ & $\mathrm{n} / \mathrm{a}$ & 79,780000 & 68,600000 \\
\hline 65 & JSL S.A. & 52,790000 & {$[\text { não] }]^{79}$} & não & 9,640000 & $\operatorname{sim}$ & $\operatorname{sim}$ & 5,300000 & não & $\operatorname{sim}$ & 5,130000 & não & não & 2,250000 & não & $\operatorname{sim}$ & 75,110000 & 62,430000 \\
\hline
\end{tabular}

${ }^{79}$ A fim de garantir a veracidade das informações levantadas quando da realização da presente pesquisa e em observância à data de corte, informa-se que a maior acionista da companhia JSL S.A. (Simpar S.A.) não seria acionista controladora, tal como constou no respectivo Formulário de Referência objeto de análise. No entanto, tendo em vista o total da participação detida pela referida acionista, bem como as informações divulgadas no Formulário de Referência disponibilizado pela companhia à CVM, 14 dias após a divulgação do formulário considerado para fins desta pesquisa, vale esclarecer que, com o objetivo de não contaminar o resultado deste estudo, a referida acionista foi considerada como acionista controladora. 
Tabela 2 - Composição do Capital Social - Identificação de Controle

\begin{tabular}{|c|c|c|c|c|c|c|c|c|c|c|c|c|c|c|c|c|c|c|}
\hline \multirow[b]{3}{*}{$\#$} & \multirow[b]{3}{*}{ Denominação } & \multicolumn{15}{|c|}{ PARTICIPAÇÃO DOS MAIORES ACIONISTAS } & \multirow[b]{3}{*}{$\begin{array}{l}\text { Total de } \\
\text { Ações } \\
(\%) \\
\end{array}$} & \multirow[b]{3}{*}{$\begin{array}{c}\text { Total } \\
\text { Controle } \\
(\%)\end{array}$} \\
\hline & & \multicolumn{3}{|c|}{$1^{\underline{0}}$} & \multicolumn{3}{|c|}{$2^{\underline{9}}$} & \multicolumn{3}{|c|}{$3^{0}$} & \multicolumn{3}{|c|}{$4^{0}$} & \multicolumn{3}{|c|}{$5^{0}$} & & \\
\hline & & $\%$ & \begin{tabular}{|c} 
Controle \\
$(15.1)$
\end{tabular} & 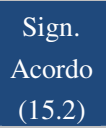 & $\%$ & $\begin{array}{c}\text { Controle } \\
(15.1)\end{array}$ & $\begin{array}{c}\text { Sign. } \\
\text { Acordo } \\
(15.2)\end{array}$ & $\%$ & $\begin{array}{c}\overline{\text { Controle }} \\
(15.1)\end{array}$ & 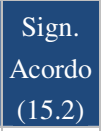 & $\%$ & \begin{tabular}{|c|} 
Controle \\
$(15.1)$
\end{tabular} & 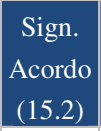 & $\%$ & $\begin{array}{c}\text { Controle } \\
(15.1)\end{array}$ & $\begin{array}{c}\text { Sign. } \\
\text { Acordo } \\
(15.2)\end{array}$ & & \\
\hline 66 & $\begin{array}{l}\text { Kroton } \\
\text { Educacional S.A. }\end{array}$ & 9,685365 & não & não & 5,914556 & não & $\operatorname{sim}$ & 5,164592 & não & $\operatorname{sim}$ & 5,164592 & não & $\operatorname{sim}$ & 5,017494 & não & não & 30,946599 & 0,000000 \\
\hline 67 & Light S.A. & 26,063473 & $\operatorname{sim}$ & $\operatorname{sim}$ & 13,462186 & não & não & 13,031737 & $\operatorname{sim}$ & $\operatorname{sim}$ & 13,031736 & $\operatorname{sim}$ & $\operatorname{sim}$ & 5,106340 & não & não & 70,695472 & 52,126946 \\
\hline 68 & Linx S.A. & 14,800000 & não & $\operatorname{sim}$ & 11,830000 & $\operatorname{sim}$ & $\operatorname{sim}$ & 10,470000 & não & $\operatorname{sim}$ & 9,800000 & $\operatorname{sim}$ & $\operatorname{sim}$ & 8,600000 & $\operatorname{sim}$ & $\operatorname{sim}$ & 55,500000 & 30,230000 \\
\hline 69 & $\begin{array}{l}\text { LLX Logística } \\
\text { S.A. }\end{array}$ & 29,700000 & $\operatorname{sim}$ & não & 23,800000 & $\operatorname{sim}$ & não & 17,880000 & não & não & $\mathrm{n} / \mathrm{a}$ & $\mathrm{n} / \mathrm{a}$ & $\mathrm{n} / \mathrm{a}$ & $\mathrm{n} / \mathrm{a}$ & $\mathrm{n} / \mathrm{a}$ & $\mathrm{n} / \mathrm{a}$ & 71,380000 & 53,500000 \\
\hline 70 & $\begin{array}{l}\text { Localiza Rent a } \\
\text { Car S.A. }\end{array}$ & 9,000000 & $\operatorname{sim}$ & não & 8,548790 & $\operatorname{sim}$ & não & 7,133122 & $\operatorname{sim}$ & não & 6,051195 & $\operatorname{sim}$ & não & 5,007628 & não & não & 24,681912 & 30,733107 \\
\hline 71 & $\begin{array}{l}\text { Log-in Logística } \\
\text { Intermodal S.A. }\end{array}$ & 31,330000 & não & não & 16,180000 & não & não & 12,800000 & não & não & 5,150000 & não & não & $\mathrm{n} / \mathrm{a}$ & $\mathrm{n} / \mathrm{a}$ & $\mathrm{n} / \mathrm{a}$ & 65,460000 & 0,000000 \\
\hline 72 & $\begin{array}{l}\text { Lojas Renner } \\
\text { S.A. }\end{array}$ & 14,290000 & não & não & 7,200000 & não & não & 5,500000 & não & não & 5,310000 & não & não & $\mathrm{n} / \mathrm{a}$ & $\mathrm{n} / \mathrm{a}$ & $\mathrm{n} / \mathrm{a}$ & 32,300000 & 0,000000 \\
\hline 73 & $\begin{array}{l}\text { LPS Brasil - } \\
\text { Consultoria de } \\
\text { Imóveis S.A. }\end{array}$ & 31,849857 & não & não & 11,653060 & não & não & 7,228446 & não & não & 5,934877 & não & não & 4,637120 & não & não & 61,303360 & 0,000000 \\
\hline 74 & Lupatech S.A. & 31,135192 & não & não & 24,453618 & não & não & 15,862532 & não & não & 6,114918 & não & não & $\mathrm{n} / \mathrm{a}$ & $\mathrm{n} / \mathrm{a}$ & $\mathrm{n} / \mathrm{a}$ & 77,566260 & 0,000000 \\
\hline 75 & $\begin{array}{l}\text { M.Dias Branco } \\
\text { S.A. Ind. Com. } \\
\text { de Alimentos }\end{array}$ & 63,067431 & $\operatorname{sim}$ & não & $\mathrm{n} / \mathrm{a}$ & $\mathrm{n} / \mathrm{a}$ & $\mathrm{n} / \mathrm{a}$ & $\mathrm{n} / \mathrm{a}$ & $\mathrm{n} / \mathrm{a}$ & $\mathrm{n} / \mathrm{a}$ & $\mathrm{n} / \mathrm{a}$ & $\mathrm{n} / \mathrm{a}$ & $\mathrm{n} / \mathrm{a}$ & $\mathrm{n} / \mathrm{a}$ & $\mathrm{n} / \mathrm{a}$ & $\mathrm{n} / \mathrm{a}$ & 63,067431 & 63,067431 \\
\hline 76 & $\begin{array}{l}\text { Magazine Luiza } \\
\text { S.A. }\end{array}$ & 60,610383 & $\operatorname{sim}$ & sim & 4,510259 & $\operatorname{sim}$ & não & 1,034616 & $\operatorname{sim}$ & não & 0,734074 & $\operatorname{sim}$ & não & 0,643732 & $\operatorname{sim}$ & não & 67,533064 & 67,533064 \\
\hline 77 & $\begin{array}{l}\text { Magnesita } \\
\text { Refratários S.A. }\end{array}$ & 30,360000 & $\operatorname{sim}$ & $\operatorname{sim}$ & 7,200000 & $\operatorname{sim}$ & $\operatorname{sim}$ & 5,040000 & não & não & 3,270000 & sim & $\operatorname{sim}$ & 0,390000 & sim & sim & 46,260000 & 41,220000 \\
\hline 78 & Marfrig & 29,170349 & $\operatorname{sim}$ & sim & 19,626104 & não & $\operatorname{sim}$ & 5,086900 & não & não & 2,331271 & sim & não & 1,616865 & sim & não & 57,831489 & 33,118485 \\
\hline
\end{tabular}


Tabela 2 - Composição do Capital Social - Identificação de Controle

\begin{tabular}{|c|c|c|c|c|c|c|c|c|c|c|c|c|c|c|c|c|c|c|}
\hline \multirow[b]{3}{*}{$\#$} & \multirow[b]{3}{*}{ Denominação } & \multicolumn{15}{|c|}{ PARTICIPAÇÃO DOS MAIORES ACIONISTAS } & \multirow[b]{3}{*}{$\begin{array}{c}\text { Total de } \\
\text { Ações } \\
(\%) \\
\end{array}$} & \multirow{3}{*}{$\begin{array}{c}\text { Total } \\
\text { Controle } \\
(\%)\end{array}$} \\
\hline & & \multicolumn{3}{|c|}{$\mathbf{1}^{\mathbf{0}}$} & \multicolumn{3}{|c|}{$2^{\underline{9}}$} & \multicolumn{3}{|c|}{$3^{\underline{0}}$} & \multicolumn{3}{|c|}{$4^{0}$} & \multicolumn{3}{|c|}{$5^{\underline{0}}$} & & \\
\hline & & $\%$ & $\begin{array}{c}\text { Controle } \\
(15.1)\end{array}$ & $\frac{\text { Sign. }}{\text { Acordo }}$ & $\%$ & \begin{tabular}{|c|} 
Controle \\
$(15.1)$
\end{tabular} & \begin{tabular}{|c|} 
Sign. \\
Acordo \\
$(15.2)$
\end{tabular} & $\%$ & $\begin{array}{c}\text { Controle } \\
(15.1)\end{array}$ & $\begin{array}{l}\text { Sign. } \\
\text { Acordo } \\
(15.2)\end{array}$ & $\%$ & $\begin{array}{c}\text { Controle } \\
(15.1)\end{array}$ & $\frac{\text { Sign. }}{\text { Acordo }}$ & $\%$ & \begin{tabular}{|c|} 
Controle \\
$(15.1)$
\end{tabular} & $\begin{array}{c}\text { Sign. } \\
\text { Acordo } \\
(15.2)\end{array}$ & & \\
\hline & Alimentos S.A. & & & & & & & & & & & & & & & & & \\
\hline 79 & $\begin{array}{l}\text { Marisa Lojas } \\
\text { S.A. }\end{array}$ & 19,033714 & $\operatorname{sim}$ & $\operatorname{sim}$ & 7,117507 & $\operatorname{sim}$ & $\operatorname{sim}$ & 6,454090 & $\operatorname{sim}$ & $\operatorname{sim}$ & 6,074601 & $\operatorname{sim}$ & $\operatorname{sim}$ & 6,074598 & $\operatorname{sim}$ & $\operatorname{sim}$ & 44,754510 & $44,754510^{80}$ \\
\hline 80 & $\begin{array}{l}\text { Mahle-Metal } \\
\text { Leve S.A. }\end{array}$ & 60,805838 & $\operatorname{sim}$ & não & 9,194192 & $\operatorname{sim}$ & não & 5,323342 & $\operatorname{sim}$ & não & 0,046621 & não & não & $\mathrm{n} / \mathrm{a}$ & $\mathrm{n} / \mathrm{a}$ & $\mathrm{n} / \mathrm{a}$ & 75,369993 & 75,323372 \\
\hline 81 & $\begin{array}{l}\text { Metalfrio } \\
\text { Solutions S.A. }\end{array}$ & 27,940000 & não & não & 26,560000 & não & não & 5,260000 & não & não & $\mathrm{n} / \mathrm{a}$ & $\mathrm{n} / \mathrm{a}$ & $\mathrm{n} / \mathrm{a}$ & $\mathrm{n} / \mathrm{a}$ & $\mathrm{n} / \mathrm{a}$ & $\mathrm{n} / \mathrm{a}$ & 59,760000 & 0,000000 \\
\hline 82 & $\begin{array}{l}\text { Mills Estrutura e } \\
\text { Serviços de } \\
\text { Engenharia S.A. }\end{array}$ & 13,900000 & $\operatorname{sim}$ & $\operatorname{sim}$ & 12,300000 & $\operatorname{sim}$ & $\operatorname{sim}$ & 9,300000 & $\operatorname{sim}$ & $\operatorname{sim}$ & 5,000000 & não & não & 2,900000 & não & não & 43,400000 & 35,500000 \\
\hline 83 & Minerva S.A. & 34,896932 & $\operatorname{sim}$ & não & 6,835815 & não & não & $\mathrm{n} / \mathrm{a}$ & $\mathrm{n} / \mathrm{a}$ & $\mathrm{n} / \mathrm{a}$ & $\mathrm{n} / \mathrm{a}$ & $\mathrm{n} / \mathrm{a}$ & $\mathrm{n} / \mathrm{a}$ & $\mathrm{n} / \mathrm{a}$ & $\mathrm{n} / \mathrm{a}$ & $\mathrm{n} / \mathrm{a}$ & 41,732747 & 34,896932 \\
\hline 84 & $\begin{array}{l}\text { MMX } \\
\text { Mineração e } \\
\text { Metálicos S.A. }\end{array}$ & 32,690000 & $\operatorname{sim}$ & não & 19,020000 & $\operatorname{sim}$ & não & 10,460000 & não & não & 8,780000 & não & não & 2,940000 & $\operatorname{sim}$ & não & 73,890000 & 54,650000 \\
\hline 85 & MPX Energia & 36,200762 & [não] & [não] & 25,187560 & $\operatorname{sim}$ & não & 10,341505 & não & não & 3,493438 & $\operatorname{sim}$ & não & 0,314975 & sim & não & 75,538240 & $65.196735^{81}$ \\
\hline
\end{tabular}

\footnotetext{
${ }^{80} \mathrm{Na}$ mesma linha de esclarecimento apresentado na nota anterior, destaca-se que, muito embora o total das participações detidas pelos cinco maiores acionistas da companhia Marisa Lojas S.A. não atinja percentual superior a 50\% do seu capital votante, a estrutura de propriedade acionária dessa companhia não foi considerada como de capital relativamente pulverizado, nos termos da classificação proposta no Capítulo 3 da presente dissertação, posto que, diferentemente das demais analisadas, Marisa Lojas declarou em seu formulário a existência de outros acionistas com participação inferior às cinco maiores apresentadas, sendo estes acionistas adicionais classificados pela companhia como integrantes do bloco de controle. Dessa forma, por termos identificado um grupo controlador detentor de mais da metade do capital social votante, e de modo a evitar a contaminação dos resultados obtidos nesta pesquisa, destaca-se que a referida companhia foi considerada com estrutura de propriedade acionária concentrada, sendo reconhecida presença de controle interno majoritário.

${ }^{81}$ Apesar de a companhia MPX Energia S.A. (atualmente denominada Eneva S.A.) não ter classificado como controladora sua acionista DD Brazil Holdings S.À.R.L., detentora de $36,200762 \%$ do capital social votante, entende-se que essa informação foi equivocadamente inserida em seu formulário de referência, uma vez que a referida acionista integra claramente o bloco de controle na companhia, por meio de acordo celebrado com outros acionistas, em 27 de maio de 2013 . Dessa forma, para fins do presente trabalho, a MPX foi considerada com estrutura de propriedade acionária concentrada, sendo reconhecida a presença de controle interno majoritário, em consonância com regra aplicada à Marisa Lojas S.A.
} 
Tabela 2 - Composição do Capital Social - Identificação de Controle

\begin{tabular}{|c|c|c|c|c|c|c|c|c|c|c|c|c|c|c|c|c|c|c|}
\hline \multirow[b]{3}{*}{$\#$} & \multirow[b]{3}{*}{ Denominação } & \multicolumn{15}{|c|}{ PARTICIPAÇÃO DOS MAIORES ACIONISTAS } & \multirow[b]{3}{*}{$\begin{array}{c}\text { Total de } \\
\text { Ações } \\
(\%) \\
\end{array}$} & \multirow{3}{*}{$\begin{array}{c}\text { Total } \\
\text { Controle } \\
(\%)\end{array}$} \\
\hline & & \multicolumn{3}{|c|}{$1^{\mathbf{0}}$} & \multicolumn{3}{|c|}{$2^{0}$} & \multicolumn{3}{|c|}{$3^{\mathbf{0}}$} & \multicolumn{3}{|c|}{$4^{0}$} & \multicolumn{3}{|c|}{$5^{0}$} & & \\
\hline & & $\%$ & $\begin{array}{c}\text { Controle } \\
(15.1)\end{array}$ & $\begin{array}{c}\text { Sign. } \\
\text { Acordo } \\
(15.2)\end{array}$ & $\%$ & \begin{tabular}{|c} 
Controle \\
$(15.1)$
\end{tabular} & \begin{tabular}{|l|} 
Sign. \\
Acordo \\
$(15.2)$
\end{tabular} & $\%$ & $\begin{array}{c}\text { Controle } \\
(15.1)\end{array}$ & \begin{tabular}{|l} 
Sign. \\
Acordo \\
$(15.2)$
\end{tabular} & $\%$ & $\begin{array}{c}\text { Controle } \\
(15.1)\end{array}$ & \begin{tabular}{|l} 
Sign. \\
Acordo \\
$(15.2)$
\end{tabular} & $\%$ & \begin{tabular}{|c|} 
Controle \\
$(15.1)$
\end{tabular} & $\begin{array}{r}\text { Sign. } \\
\text { Acordo } \\
(15.2)\end{array}$ & & \\
\hline & S.A. & & & & & & & & & & & & & & & & & \\
\hline 86 & $\begin{array}{l}\text { MRV } \\
\text { Engenharia e } \\
\text { Participações } \\
\text { S.A. }\end{array}$ & 33,000000 & $\operatorname{sim}$ & não & 5,300000 & não & não & 5,100000 & não & não & 5,100000 & não & não & $\mathrm{n} / \mathrm{a}$ & $\mathrm{n} / \mathrm{a}$ & $\mathrm{n} / \mathrm{a}$ & 48,500000 & 33,000000 \\
\hline 87 & Multiplus S.A. & 78,870000 & $\operatorname{sim}$ & não & 0,000100 & não & não & $\mathrm{n} / \mathrm{a}$ & $\mathrm{n} / \mathrm{a}$ & $\mathrm{n} / \mathrm{a}$ & $\mathrm{n} / \mathrm{a}$ & $\mathrm{n} / \mathrm{a}$ & $\mathrm{n} / \mathrm{a}$ & $\mathrm{n} / \mathrm{a}$ & $\mathrm{n} / \mathrm{a}$ & $\mathrm{n} / \mathrm{a}$ & 78,870100 & 78,870000 \\
\hline 88 & $\begin{array}{l}\text { Natura } \\
\text { Cosméticos S.A. }\end{array}$ & 22,249100 & $\operatorname{sim}$ & $\operatorname{sim}$ & 21,231400 & $\operatorname{sim}$ & $\operatorname{sim}$ & 5,242300 & $\operatorname{sim}$ & $\operatorname{sim}$ & 5,236900 & $\operatorname{sim}$ & $\operatorname{sim}$ & 3,691400 & $\operatorname{sim}$ & $\operatorname{sim}$ & 57,651100 & 57,651100 \\
\hline 89 & Odontoprev S.A. & 43,500000 & $\operatorname{sim}$ & $\operatorname{sim}$ & 7,540000 & $\operatorname{sim}$ & $\operatorname{sim}$ & 5,030000 & não & não & 0,020000 & sim & $\operatorname{sim}$ & $\mathrm{n} / \mathrm{a}$ & $\mathrm{n} / \mathrm{a}$ & $\mathrm{n} / \mathrm{a}$ & 56,090000 & 51,060000 \\
\hline 90 & $\begin{array}{l}\text { OGX Petróleo e } \\
\text { Gás } \\
\text { Participações } \\
\text { S.A. }\end{array}$ & 57,520000 & $\operatorname{sim}$ & não & 3,580000 & $\operatorname{sim}$ & não & $\mathrm{n} / \mathrm{a}$ & $\mathrm{n} / \mathrm{a}$ & $\mathrm{n} / \mathrm{a}$ & $\mathrm{n} / \mathrm{a}$ & $\mathrm{n} / \mathrm{a}$ & $\mathrm{n} / \mathrm{a}$ & $\mathrm{n} / \mathrm{a}$ & $\mathrm{n} / \mathrm{a}$ & $\mathrm{n} / \mathrm{a}$ & 61,100000 & 61,100000 \\
\hline 91 & OSX Brasil S.A. & 62,750000 & $\operatorname{sim}$ & não & 12,080000 & $\operatorname{sim}$ & não & 5,050000 & não & não & $\mathrm{n} / \mathrm{a}$ & $\mathrm{n} / \mathrm{a}$ & $\mathrm{n} / \mathrm{a}$ & $\mathrm{n} / \mathrm{a}$ & $\mathrm{n} / \mathrm{a}$ & $\mathrm{n} / \mathrm{a}$ & 79,880000 & 74,830000 \\
\hline 92 & $\begin{array}{l}\text { Paranapanema } \\
\text { S.A. }\end{array}$ & 23,960000 & não & não & 17,230000 & não & não & 12,140000 & não & não & 8,420000 & não & não & $\mathrm{n} / \mathrm{a}$ & $\mathrm{n} / \mathrm{a}$ & $\mathrm{n} / \mathrm{a}$ & 61,750000 & 0,000000 \\
\hline 93 & $\begin{array}{l}\text { PDG Realty S.A. } \\
\text { Empreend. e } \\
\text { Participações }\end{array}$ & 9,020000 & não & não & 5,960000 & não & não & 5,700000 & não & não & 5,090000 & não & não & $\mathrm{n} / \mathrm{a}$ & $\mathrm{n} / \mathrm{a}$ & $\mathrm{n} / \mathrm{a}$ & 25,770000 & 0,000000 \\
\hline 94 & $\begin{array}{l}\text { Porto Seguro } \\
\text { S.A. }\end{array}$ & 70,815596 & $\operatorname{sim}$ & não & 0,000001 & $\operatorname{sim}$ & $\operatorname{sim}$ & $\mathrm{n} / \mathrm{a}$ & $\mathrm{n} / \mathrm{a}$ & $\mathrm{n} / \mathrm{a}$ & $\mathrm{n} / \mathrm{a}$ & $\mathrm{n} / \mathrm{a}$ & $\mathrm{n} / \mathrm{a}$ & $\mathrm{n} / \mathrm{a}$ & $\mathrm{n} / \mathrm{a}$ & $\mathrm{n} / \mathrm{a}$ & 70,815597 & 70,815597 \\
\hline 95 & Portobello S.A. & 21,570000 & não & não & 15,350000 & $\operatorname{sim}$ & $\operatorname{sim}$ & 13,740000 & $\operatorname{sim}$ & $\operatorname{sim}$ & 5,650000 & $\operatorname{sim}$ & $\operatorname{sim}$ & 5,580000 & sim & $\operatorname{sim}$ & 61,890000 & $40,320000^{82}$ \\
\hline
\end{tabular}

${ }^{82}$ Considerando que a Portobello S.A. declarou em seu formulário a existência de outros acionistas com participação inferior às cinco maiores apresentadas, e que esses acionistas adicionais foram classificados pela companhia como integrantes do bloco de controle, destaca-se que a Portobello, em conformidade com a regra aplicada em casos semelhantes, foi considerada com estrutura de propriedade acionária concentrada, sendo, portanto, reconhecida a presença de controle interno majoritário, com o objetivo de evitar a contaminação dos resultados obtidos na presente pesquisa empírica. 
Tabela 2 - Composição do Capital Social - Identificação de Controle

\begin{tabular}{|c|c|c|c|c|c|c|c|c|c|c|c|c|c|c|c|c|c|c|}
\hline \multirow[b]{3}{*}{$\#$} & \multirow[b]{3}{*}{ Denominação } & \multicolumn{15}{|c|}{ PARTICIPAÇÃO DOS MAIORES ACIONISTAS } & \multirow[b]{3}{*}{$\begin{array}{c}\text { Total de } \\
\text { Ações } \\
(\%) \\
\end{array}$} & \multirow{3}{*}{$\begin{array}{c}\text { Total } \\
\text { Controle } \\
(\%)\end{array}$} \\
\hline & & \multicolumn{3}{|c|}{$1^{0}$} & \multicolumn{3}{|c|}{$2^{\underline{9}}$} & \multicolumn{3}{|c|}{$3^{0}$} & \multicolumn{3}{|c|}{$4^{0}$} & \multicolumn{3}{|c|}{$5^{0}$} & & \\
\hline & & $\%$ & $\begin{array}{c}\text { Controle } \\
(15.1)\end{array}$ & $\begin{array}{c}\text { Sign. } \\
\text { Acordo } \\
(15.2)\end{array}$ & $\%$ & \begin{tabular}{|c|} 
Controle \\
$(15.1)$
\end{tabular} & \begin{tabular}{|l|} 
Sign. \\
Acordo \\
$(15.2)$
\end{tabular} & $\%$ & $\begin{array}{c}\overline{\text { Controle }} \\
(15.1)\end{array}$ & \begin{tabular}{|l} 
Sign. \\
Acordo \\
$(15.2)$
\end{tabular} & $\%$ & $\begin{array}{c}\text { Controle } \\
(15.1)\end{array}$ & 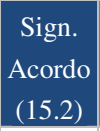 & $\%$ & $\begin{array}{c}\text { Controle } \\
(15.1)\end{array}$ & $\begin{array}{r}\text { Sign. } \\
\text { Acordo } \\
(15.2)\end{array}$ & & \\
\hline 96 & $\begin{array}{l}\text { Positivo } \\
\text { Informática S.A. }\end{array}$ & 14,144213 & $\operatorname{sim}$ & $\operatorname{sim}$ & 14,144213 & $\operatorname{sim}$ & $\operatorname{sim}$ & 14,144213 & $\operatorname{sim}$ & $\operatorname{sim}$ & 4,714737 & $\operatorname{sim}$ & $\operatorname{sim}$ & 4,714737 & $\operatorname{sim}$ & $\operatorname{sim}$ & 51,862113 & 51,862113 \\
\hline 97 & $\begin{array}{l}\text { Profarma Distrib. } \\
\text { Produtos } \\
\text { Farmacêuticos } \\
\text { S.A. }\end{array}$ & 55,077963 & $\operatorname{sim}$ & não & 15,007748 & não & não & 11,250260 & não & não & 0,743220 & $\operatorname{sim}$ & $\operatorname{sim}$ & 0,446515 & não & não & 82,525706 & 55,821183 \\
\hline 98 & $\begin{array}{l}\text { QGEP } \\
\text { Participações } \\
\text { S.A. }\end{array}$ & 63,000354 & $\operatorname{sim}$ & $\operatorname{sim}$ & 7,000039 & $\operatorname{sim}$ & $\operatorname{sim}$ & 5,182785 & não & não & 0,090755 & não & não & $\mathrm{n} / \mathrm{a}$ & $\mathrm{n} / \mathrm{a}$ & $\mathrm{n} / \mathrm{a}$ & 75,273933 & 70,000393 \\
\hline 99 & Qualicorp S.A. & 25,400162 & $\operatorname{sim}$ & $\operatorname{sim}$ & 10,333934 & não & não & 5,226082 & não & não & $\mathrm{n} / \mathrm{a}$ & $\mathrm{n} / \mathrm{a}$ & $\mathrm{n} / \mathrm{a}$ & $\mathrm{n} / \mathrm{a}$ & $\mathrm{n} / \mathrm{a}$ & $\mathrm{n} / \mathrm{a}$ & 40,960178 & 25,400162 \\
\hline 100 & $\begin{array}{l}\text { Raia Drogasil } \\
\text { S.A. }\end{array}$ & 10,799992 & $\operatorname{sim}$ & $\operatorname{sim}$ & 5,360058 & $\operatorname{sim}$ & $\operatorname{sim}$ & 5,070452 & $\operatorname{sim}$ & $\operatorname{sim}$ & 5,042844 & não & não & 5,005001 & não & não & 31,278347 & 21,230502 \\
\hline 101 & $\begin{array}{l}\text { Renar Maçãs } \\
\text { S.A. }\end{array}$ & 38,370000 & $\operatorname{sim}$ & $\operatorname{sim}$ & 11,900000 & $\operatorname{sim}$ & $\operatorname{sim}$ & 7,220000 & $\operatorname{sim}$ & $\operatorname{sim}$ & 5,650000 & $\operatorname{sim}$ & $\operatorname{sim}$ & $\mathrm{n} / \mathrm{a}$ & $\mathrm{n} / \mathrm{a}$ & $\mathrm{n} / \mathrm{a}$ & 63,140000 & 63,140000 \\
\hline 102 & $\begin{array}{l}\text { Restoque } \\
\text { Comércio e } \\
\text { Confecções de } \\
\text { Roupas S.A. }\end{array}$ & 15,780000 & não & não & 12,520000 & não & não & 9,880000 & não & não & 8,710000 & não & não & 7,320000 & não & não & 54,210000 & 0,000000 \\
\hline 103 & $\begin{array}{l}\text { Rodobens } \\
\text { Negócios } \\
\text { Imobiliários S.A. }\end{array}$ & 27,606666 & $\operatorname{sim}$ & $\operatorname{sim}$ & 12,319043 & não & não & 11,404507 & $\operatorname{sim}$ & $\operatorname{sim}$ & 6,999457 & $\operatorname{sim}$ & $\operatorname{sim}$ & 6,602793 & $\operatorname{sim}$ & $\operatorname{sim}$ & 64,932466 & 52,613423 \\
\hline 104 & $\begin{array}{l}\text { Rossi } \\
\text { Residencial S.A. }\end{array}$ & 8,736002 & $\operatorname{sim}$ & $\operatorname{sim}$ & 7,069465 & $\operatorname{sim}$ & $\operatorname{sim}$ & 6,620930 & não & não & 6,567830 & não & $\operatorname{sim}$ & 6,123570 & não & não & 35,117797 & 15,805467 \\
\hline 105 & $\begin{array}{l}\text { São Carlos } \\
\text { Empreend. e } \\
\text { Participações } \\
\text { S.A. }\end{array}$ & 18,580908 & $\operatorname{sim}$ & $\operatorname{sim}$ & 16,878764 & não & não & 13,724990 & $\operatorname{sim}$ & $\operatorname{sim}$ & 10,477350 & $\operatorname{sim}$ & $\operatorname{sim}$ & $\begin{array}{c}10,47735 \\
0\end{array}$ & $\operatorname{sim}$ & $\operatorname{sim}$ & 53,260598 & 53,260598 \\
\hline 106 & São Martinho & 56,120000 & $\operatorname{sim}$ & não & 0,110000 & não & não & 0,000001 & não & não & 0,000001 & não & não & 0,000001 & não & não & 56,120000 & 56,120000 \\
\hline
\end{tabular}


Tabela 2 - Composição do Capital Social - Identificação de Controle

\begin{tabular}{|c|c|c|c|c|c|c|c|c|c|c|c|c|c|c|c|c|c|c|}
\hline \multirow[b]{3}{*}{$\#$} & \multirow[b]{3}{*}{ Denominação } & \multicolumn{15}{|c|}{ PARTICIPAÇÃO DOS MAIORES ACIONISTAS } & \multirow[b]{3}{*}{$\begin{array}{c}\text { Total de } \\
\text { Ações } \\
(\%) \\
\end{array}$} & \multirow{3}{*}{$\begin{array}{c}\text { Total } \\
\text { Controle } \\
(\%)\end{array}$} \\
\hline & & \multicolumn{3}{|c|}{$1^{\underline{0}}$} & \multicolumn{3}{|c|}{$2^{\underline{9}}$} & \multicolumn{3}{|c|}{$3^{\underline{0}}$} & \multicolumn{3}{|c|}{$4^{0}$} & \multicolumn{3}{|c|}{$5^{0}$} & & \\
\hline & & $\%$ & $\begin{array}{c}\text { Controle } \\
(15.1)\end{array}$ & $\frac{\text { Sign. }}{\text { Acordo }}$ & $\%$ & \begin{tabular}{|c|} 
Controle \\
$(15.1)$
\end{tabular} & \begin{tabular}{|l} 
Sign. \\
Acordo \\
$(15.2)$
\end{tabular} & $\%$ & $\begin{array}{c}\text { Controle } \\
(15.1)\end{array}$ & 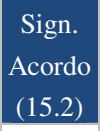 & $\%$ & $\begin{array}{c}\text { Controle } \\
(15.1)\end{array}$ & 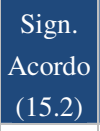 & $\%$ & \begin{tabular}{|c|} 
Controle \\
$(15.1)$
\end{tabular} & $\begin{array}{c}\text { Sign. } \\
\text { Acordo } \\
(15.2)\end{array}$ & & \\
\hline & S.A. & & & & & & & & & & & & & & & & & \\
\hline 107 & $\begin{array}{l}\text { SLC Agrícola } \\
\text { S.A. }\end{array}$ & 51,030000 & não & não & 4,930000 & não & não & 4,740000 & não & não & $\mathrm{n} / \mathrm{a}$ & $\mathrm{n} / \mathrm{a}$ & $\mathrm{n} / \mathrm{a}$ & $\mathrm{n} / \mathrm{a}$ & $\mathrm{n} / \mathrm{a}$ & $\mathrm{n} / \mathrm{a}$ & 60,700000 & 60,700000 \\
\hline 108 & $\begin{array}{l}\text { Sonae Sierra } \\
\text { Brasil S.A. }\end{array}$ & 66,650000 & $\operatorname{sim}$ & não & $\mathrm{n} / \mathrm{a}$ & $\mathrm{n} / \mathrm{a}$ & $\mathrm{n} / \mathrm{a}$ & $\mathrm{n} / \mathrm{a}$ & $\mathrm{n} / \mathrm{a}$ & $\mathrm{n} / \mathrm{a}$ & $\mathrm{n} / \mathrm{a}$ & $\mathrm{n} / \mathrm{a}$ & $\mathrm{n} / \mathrm{a}$ & $\mathrm{n} / \mathrm{a}$ & $\mathrm{n} / \mathrm{a}$ & $\mathrm{n} / \mathrm{a}$ & 66,650000 & 66,650000 \\
\hline 109 & Smiles S.A. & 57,295000 & $\operatorname{sim}$ & $\operatorname{sim}$ & 15,088000 & não & $\operatorname{sim}$ & $\mathrm{n} / \mathrm{a}$ & $\mathrm{n} / \mathrm{a}$ & $\mathrm{n} / \mathrm{a}$ & $\mathrm{n} / \mathrm{a}$ & $\mathrm{n} / \mathrm{a}$ & $\mathrm{n} / \mathrm{a}$ & $\mathrm{n} / \mathrm{a}$ & $\mathrm{n} / \mathrm{a}$ & $\mathrm{n} / \mathrm{a}$ & 72,383000 & 72,383000 \\
\hline 110 & $\begin{array}{l}\text { Springs Global } \\
\text { Participações } \\
\text { S.A. }\end{array}$ & 52,910000 & $\operatorname{sim}$ & $\operatorname{sim}$ & 24,200000 & não & não & $\mathrm{n} / \mathrm{a}$ & $\mathrm{n} / \mathrm{a}$ & $\mathrm{n} / \mathrm{a}$ & $\mathrm{n} / \mathrm{a}$ & $\mathrm{n} / \mathrm{a}$ & $\mathrm{n} / \mathrm{a}$ & $\mathrm{n} / \mathrm{a}$ & $\mathrm{n} / \mathrm{a}$ & $\mathrm{n} / \mathrm{a}$ & 77,110000 & 52,910000 \\
\hline 111 & $\begin{array}{l}\text { T4F } \\
\text { Entretenimento } \\
\text { S.A. }\end{array}$ & 26,520000 & $\operatorname{sim}$ & $\operatorname{sim}$ & 9,460000 & não & não & 8,380000 & $\operatorname{sim}$ & $\operatorname{sim}$ & 6,170000 & não & não & 5,540000 & $\operatorname{sim}$ & sim & 56,070000 & 40,440000 \\
\hline 112 & $\begin{array}{l}\text { Tarpon } \\
\text { Investimentos } \\
\text { S.A. }\end{array}$ & 47,370000 & $\operatorname{sim}$ & $\operatorname{sim}$ & 8,140000 & não & não & 5,790000 & [não] & $\operatorname{sim}$ & 3,070000 & [não] & $\operatorname{sim}$ & 3,040000 & [não] & $\operatorname{sim}$ & 67,410000 & $59.270000^{83}$ \\
\hline 113 & Technos S.A. & 37,440000 & não & não & 19,800000 & não & não & 8,750000 & não & não & $\mathrm{n} / \mathrm{a}$ & $\mathrm{n} / \mathrm{a}$ & $\mathrm{n} / \mathrm{a}$ & $\mathrm{n} / \mathrm{a}$ & $\mathrm{n} / \mathrm{a}$ & $\mathrm{n} / \mathrm{a}$ & 65,990000 & 0,000000 \\
\hline 114 & Tecnisa S.A. & 43,018484 & $\operatorname{sim}$ & não & 6,802221 & não & não & 6,303612 & $\operatorname{sim}$ & não & 6,224050 & não & não & 3,027748 & $\operatorname{sim}$ & não & 65,376115 & 52,349844 \\
\hline 115 & $\begin{array}{l}\text { Tegma Gestão } \\
\text { Logística S.A. }\end{array}$ & 38,340000 & $\operatorname{sim}$ & $\operatorname{sim}$ & 25,520000 & $\operatorname{sim}$ & $\operatorname{sim}$ & 0,700000 & $\operatorname{sim}$ & $\operatorname{sim}$ & 0,000800 & $\operatorname{sim}$ & $\operatorname{sim}$ & 0,000100 & $\operatorname{sim}$ & $\operatorname{sim}$ & 64,560900 & 64,560900 \\
\hline 116 & $\begin{array}{l}\text { Tempo } \\
\text { Participações }\end{array}$ & 20,374962 & não & não & 17,270365 & não & não & 15,320281 & não & não & 6,189660 & não & não & 5,514767 & não & não & 64,670035 & 0,000000 \\
\hline
\end{tabular}

\footnotetext{
${ }^{83}$ A despeito de a Tarpon Investimentos S.A. ter classificado apenas a sua acionista majoritária como controladora, verificou-se, ao analisar o acordo de acionistas da companhia, para fins do presente trabalho, que alguns dos demais acionistas detentores de participação superior a $5 \%$ do capital social integrariam bloco de controle da companhia, exercendo o seu controle compartilhado por meio de participação total superior à maioria do capital votante. Dessa forma, conforme regra aplicada a casos semelhantes, a companhia foi considerada com estrutura de propriedade acionária concentrada, sendo, portanto, reconhecida a presença de controle interno majoritário, com o objetivo de evitar a contaminação dos resultados obtidos na presente pesquisa empírica.
} 
Tabela 2 - Composição do Capital Social - Identificação de Controle

\begin{tabular}{|c|c|c|c|c|c|c|c|c|c|c|c|c|c|c|c|c|c|c|}
\hline \multirow[b]{3}{*}{$\#$} & \multirow[b]{3}{*}{ Denominação } & \multicolumn{15}{|c|}{ PARTICIPAÇÃO DOS MAIORES ACIONISTAS } & \multirow{3}{*}{$\begin{array}{c}\text { Total de } \\
\text { Ações } \\
(\%) \\
\end{array}$} & \multirow{3}{*}{$\begin{array}{c}\text { Total } \\
\text { Controle } \\
(\%)\end{array}$} \\
\hline & & \multicolumn{3}{|c|}{$1^{\underline{9}}$} & \multicolumn{3}{|c|}{$2^{\underline{9}}$} & \multicolumn{3}{|c|}{$3^{\mathbf{0}}$} & \multicolumn{3}{|c|}{$4^{0}$} & \multicolumn{3}{|c|}{$5^{0}$} & & \\
\hline & & $\%$ & $\begin{array}{c}\text { Controle } \\
(15.1)\end{array}$ & $\begin{array}{c}\text { Sign. } \\
\text { Acordo } \\
(15.2)\end{array}$ & $\%$ & $\begin{array}{c}\overline{\text { Controle }} \\
(15.1)\end{array}$ & \begin{tabular}{|l|} 
Sign. \\
Acordo \\
$(15.2)$
\end{tabular} & $\%$ & $\begin{array}{c}\overline{\text { Controle }} \\
(15.1)\end{array}$ & \begin{tabular}{|l|} 
Sign. \\
Acordo \\
$(15.2)$
\end{tabular} & $\%$ & $\begin{array}{c}\text { Controle } \\
(15.1)\end{array}$ & \begin{tabular}{|l} 
Sign. \\
Acordo \\
$(15.2)$
\end{tabular} & $\%$ & $\begin{array}{c}\text { Controle } \\
(15.1)\end{array}$ & $\begin{array}{c}\text { Sign. } \\
\text { Acordo } \\
(15.2)\end{array}$ & & \\
\hline & S.A. & & & & & & & & & & & & & & & & & \\
\hline 117 & $\begin{array}{l}\text { Tereos } \\
\text { Internacional } \\
\text { S.A. }\end{array}$ & 52,650000 & $\operatorname{sim}$ & não & 13,230000 & $\operatorname{sim}$ & não & 3,740000 & $\operatorname{sim}$ & não & $\mathrm{n} / \mathrm{a}$ & $\mathrm{n} / \mathrm{a}$ & $\mathrm{n} / \mathrm{a}$ & $\mathrm{n} / \mathrm{a}$ & $\mathrm{n} / \mathrm{a}$ & $\mathrm{n} / \mathrm{a}$ & 69,620000 & 69,620000 \\
\hline 118 & $\begin{array}{l}\text { Tim } \\
\text { Participações } \\
\text { S.A. }\end{array}$ & 66,675553 & $\operatorname{sim}$ & não & 0,000147 & não & não & $\mathrm{n} / \mathrm{a}$ & $\mathrm{n} / \mathrm{a}$ & $\mathrm{n} / \mathrm{a}$ & $\mathrm{n} / \mathrm{a}$ & $\mathrm{n} / \mathrm{a}$ & $\mathrm{n} / \mathrm{a}$ & $\mathrm{n} / \mathrm{a}$ & $\mathrm{n} / \mathrm{a}$ & $\mathrm{n} / \mathrm{a}$ & 66,675700 & 66,675553 \\
\hline 119 & Totvs S.A. & 16,498458 & não & não & 9,890299 & não & não & 1,105877 & não & não & 0,026818 & não & não & 0,010364 & não & não & 27,531816 & 0,000000 \\
\hline 120 & $\begin{array}{l}\text { TPI - Triunfo } \\
\text { Part. e } \\
\text { Investimentos } \\
\text { S.A. }\end{array}$ & 61,649860 & $\operatorname{sim}$ & não & 7,036986 & não & não & 5,856233 & não & não & 5,397260 & não & não & 1,061644 & $\operatorname{sim}$ & não & 81,001983 & 62,711504 \\
\hline 121 & $\begin{array}{l}\text { Tractebel } \\
\text { Energia S.A. }\end{array}$ & 68,710000 & $\operatorname{sim}$ & não & 10,000000 & não & não & $\mathrm{n} / \mathrm{a}$ & $\mathrm{n} / \mathrm{a}$ & $\mathrm{n} / \mathrm{a}$ & $\mathrm{n} / \mathrm{a}$ & $\mathrm{n} / \mathrm{a}$ & $\mathrm{n} / \mathrm{a}$ & $\mathrm{n} / \mathrm{a}$ & $\mathrm{n} / \mathrm{a}$ & $\mathrm{n} / \mathrm{a}$ & 78,710000 & 68,710000 \\
\hline 122 & Trisul S.A. & 52,860000 & $\operatorname{sim}$ & não & 15,760000 & não & não & 5,760000 & não & $\operatorname{sim}$ & $\mathrm{n} / \mathrm{a}$ & $\mathrm{n} / \mathrm{a}$ & $\mathrm{n} / \mathrm{a}$ & $\mathrm{n} / \mathrm{a}$ & $\mathrm{n} / \mathrm{a}$ & $\mathrm{n} / \mathrm{a}$ & 74,380000 & 52,860000 \\
\hline 123 & $\begin{array}{l}\text { Ultrapar } \\
\text { Participações } \\
\text { S.A. }\end{array}$ & 23,67 & não & sim & 11,977821 & não & não & 7,868335 & não & não & 5,935479 & não & não & $\mathrm{n} / \mathrm{a}$ & $\mathrm{n} / \mathrm{a}$ & $\mathrm{n} / \mathrm{a}$ & 49,447581 & 0,000000 \\
\hline 124 & $\begin{array}{l}\text { Unicasa } \\
\text { Indústria de } \\
\text { Móveis S.A. }\end{array}$ & 39,780000 & $\operatorname{sim}$ & $\operatorname{sim}$ & 8,620000 & $\operatorname{sim}$ & $\operatorname{sim}$ & 5,160000 & não & não & 5,160000 & não & não & 5,130000 & não & não & 63,850000 & $48,400000^{84}$ \\
\hline 125 & $\begin{array}{l}\text { Valid Soluções e } \\
\text { Serv. Seg. Meios }\end{array}$ & 9,670000 & não & não & 4,460000 & não & não & 4,290000 & não & não & 2,440000 & não & não & 2,120000 & não & não & 22,980000 & 0,000000 \\
\hline
\end{tabular}

${ }^{84}$ Considerando que a Unicasa Indústria de Imóveis S.A. declarou em seu formulário a existência de outros acionistas com participação inferior às cinco maiores apresentadas, e que esses acionistas adicionais foram classificados pela companhia como integrantes do bloco de controle, salienta-se que a Unicasa, seguindo a regra aplicada em casos semelhantes, foi considerada com estrutura de propriedade acionária concentrada, sendo, portanto, reconhecida a presença de controle interno majoritário, com o objetivo de evitar a contaminação dos resultados obtidos na presente pesquisa empírica. 
Tabela 2 - Composição do Capital Social - Identificação de Controle

\begin{tabular}{|c|c|c|c|c|c|c|c|c|c|c|c|c|c|c|c|c|c|c|}
\hline \multirow[b]{3}{*}{$\#$} & \multirow[b]{3}{*}{ Denominação } & \multicolumn{15}{|c|}{ PARTICIPAÇÃO DOS MAIORES ACIONISTAS } & \multirow[b]{3}{*}{$\begin{array}{c}\text { Total de } \\
\text { Ações } \\
(\%) \\
\end{array}$} & \multirow[b]{3}{*}{$\begin{array}{c}\text { Total } \\
\text { Controle } \\
(\%)\end{array}$} \\
\hline & & \multicolumn{3}{|c|}{$\mathbf{1}^{\mathbf{e}}$} & \multicolumn{3}{|c|}{$2^{9}$} & \multicolumn{3}{|c|}{\begin{tabular}{|l|}
$3^{\mathbf{0}}$ \\
\end{tabular}} & \multicolumn{3}{|c|}{$4^{0}$} & \multicolumn{3}{|c|}{$5^{\underline{0}}$} & & \\
\hline & & $\%$ & $\begin{array}{c}\text { Controle } \\
(15.1)\end{array}$ & 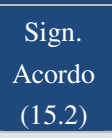 & $\%$ & \begin{tabular}{|c|} 
Controle \\
$(15.1)$
\end{tabular} & \begin{tabular}{|c|} 
Sign. \\
Acordo \\
$(15.2)$
\end{tabular} & $\%$ & $\begin{array}{c}\text { Controle } \\
(15.1)\end{array}$ & \begin{tabular}{|c|} 
Sign. \\
Acordo \\
$(15.2)$
\end{tabular} & $\%$ & \begin{tabular}{|} 
Controle \\
$(15.1)$
\end{tabular} & \begin{tabular}{|l|} 
Sign. \\
Acordo \\
$(15.2)$
\end{tabular} & $\%$ & \begin{tabular}{|c|} 
Controle \\
$(15.1)$
\end{tabular} & $\begin{array}{c}\text { Sign. } \\
\text { Acordo } \\
(15.2)\end{array}$ & & \\
\hline & Pag. Ident. S.A. & & & & & & & & & & & & & & & & & \\
\hline 126 & $\begin{array}{l}\text { Vanguarda Agro } \\
\text { S.A. }\end{array}$ & 19,520000 & não & não & 11,080000 & não & não & 7,870000 & não & não & 6,560000 & não & não & 4,810000 & não & não & 49,840000 & 0,000000 \\
\hline 127 & $\begin{array}{l}\text { Vigor Alimentos } \\
\text { S.A. }\end{array}$ & 44,620000 & $\operatorname{sim}$ & $\operatorname{sim}$ & 31,410000 & não & $\operatorname{sim}$ & 21,120000 & $\operatorname{sim}$ & $\operatorname{sim}$ & $\mathrm{n} / \mathrm{a}$ & $\mathrm{n} / \mathrm{a}$ & $\mathrm{n} / \mathrm{a}$ & $\mathrm{n} / \mathrm{a}$ & $\mathrm{n} / \mathrm{a}$ & $\mathrm{n} / \mathrm{a}$ & 97,150000 & 65,740000 \\
\hline 128 & $\begin{array}{l}\text { Viver } \\
\text { Incorporadora e } \\
\text { Construtora S.A. }\end{array}$ & 39,960000 & não & não & 11,930000 & não & não & 8,070000 & não & não & 7,610000 & não & não & 4,740000 & não & não & 72,310000 & 0,000000 \\
\hline 129 & Weg S.A. & 50,135349 & sim & não & 1,765716 & $\operatorname{sim}$ & não & 1,644454 & $\operatorname{sim}$ & não & 1,644454 & $\operatorname{sim}$ & não & 1,029937 & $\operatorname{sim}$ & não & 56,219910 & 56,219910 \\
\hline
\end{tabular}




\section{APÊNDICE C}

Tabela 3 - Perfil dos Acionistas de Companhias sem Controle Majoritário ${ }^{85}$ (Grupo A)

\begin{tabular}{|c|c|c|c|c|c|c|c|c|c|c|c|}
\hline & & & COMPAI & HIAS COM & ONTROLE & NÃO MAJO & RITÁRIO ( & RUPO A) & & & \\
\hline & & & Acionistas & Pessoa Física & $\begin{array}{r}\text { Acionist: } \\
\text { Jurí }\end{array}$ & $\begin{array}{l}\text { as Pessoa } \\
\text { ídica }\end{array}$ & $\begin{array}{l}\text { Inve: } \\
\text { Instit }\end{array}$ & $\begin{array}{l}\text { tidores } \\
\text { ucionais }\end{array}$ & $\begin{array}{l}\text { Ações } \\
\text { em }\end{array}$ & Total & Maior \\
\hline$\#$ & Denominação & $\begin{array}{l}\text { Total de } \\
\text { Acionistas }\end{array}$ & $\begin{array}{c}\begin{array}{c}\text { Número } \\
\text { de } \\
\text { Acionistas }\end{array} \\
\end{array}$ & $\begin{array}{l}\text { Proporção } \\
\text { entre } \\
\text { Acionistas }\end{array}$ & $\begin{array}{c}\text { Número } \\
\text { de } \\
\text { Acionistas }\end{array}$ & $\begin{array}{c}\text { Proporção } \\
\text { entre } \\
\text { Acionistas }\end{array}$ & $\begin{array}{c}\begin{array}{c}\text { Número } \\
\text { de } \\
\text { Acionistas }\end{array} \\
\end{array}$ & $\begin{array}{c}\text { Proporção } \\
\text { entre } \\
\text { Acionistas }\end{array}$ & $\begin{array}{l}\text { Circu- } \\
\text { lação } \\
(\%)^{86}\end{array}$ & $\begin{array}{c}\text { Controle } \\
\text { Tabela } 2 \\
(\%)\end{array}$ & $\begin{array}{c}\text { Acionista } \\
\text { Tabela } 2 \\
(\%)\end{array}$ \\
\hline 1 & $\begin{array}{l}\text { Aliansce Shopping Centers } \\
\text { S.A. }\end{array}$ & 986 & 591 & $59,94 \%$ & 257 & $26,06 \%$ & 138 & $14,00 \%$ & 61,21 & 37,40588 & 28,030663 \\
\hline 2 & $\begin{array}{l}\text { ALL América Latina } \\
\text { Logística S.A. }\end{array}$ & 11.691 & 10.112 & $86,49 \%$ & 1.237 & $10,58 \%$ & 342 & $2,93 \%$ & 62,92 & 22,661992 & 23,510000 \\
\hline 3 & $\begin{array}{l}\text { BHG S.A. - Brazil } \\
\text { Hospitality Group }\end{array}$ & 400 & 229 & $57,25 \%$ & 15 & $3,75 \%$ & 156 & $39,00 \%$ & 67,94 & 30,175700 & 29,507800 \\
\hline 4 & $\begin{array}{l}\text { Brasilagro - Cia. Bras. de } \\
\text { Prop. Agrícolas }\end{array}$ & 525 & 279 & $53,14 \%$ & 50 & $9,52 \%$ & 196 & $37,33 \%$ & 60,36 & 39,643099 & 25,439386 \\
\hline 5 & $\begin{array}{l}\text { Brasil Brokers Participações } \\
\text { S.A. }\end{array}$ & 1.153 & 636 & $55,16 \%$ & 13 & $1,13 \%$ & 504 & $43,71 \%$ & 79,19 & 16,446142 & 10,047441 \\
\hline 6 & $\begin{array}{l}\text { Brasil Insurance Particip. e } \\
\text { Administração S.A. }\end{array}$ & 971 & 601 & $61,89 \%$ & 11 & $1,13 \%$ & 359 & $36,97 \%$ & 68,00 & 6,480000 & 6,480000 \\
\hline 7 & $\begin{array}{l}\text { Brookfield Incorporações } \\
\text { S.A. }\end{array}$ & 10.408 & 9.729 & $93,48 \%$ & 448 & $4,30 \%$ & 231 & $2,22 \%$ & 47,07 & 46,770000 & 38,530000 \\
\hline 8 & $\begin{array}{l}\text { Companhia de Locação das } \\
\text { Américas }\end{array}$ & 320 & 146 & $45,63 \%$ & 5 & $1,56 \%$ & 169 & $52,81 \%$ & 52,98 & 47,020000 & 23,510000 \\
\hline 9 & $\begin{array}{l}\text { Cyrela Brazil Realty S.A. } \\
\text { Empreend. Part. }\end{array}$ & 8.315 & 6.939 & $83,45 \%$ & 701 & $8,43 \%$ & 675 & $8,12 \%$ & 43,50 & 28,807475 & 23,551374 \\
\hline
\end{tabular}

${ }^{85}$ Conforme dados divulgados pelas companhias listadas no segmento do Novo Mercado, no item 15.3 da última versão dos respectivos Formulários de Referência divulgados até 31 de maio de 2013. Informações disponíveis em: <http://www.cvm.gov.br>. Acesso em: out. 2013.

${ }^{86}$ Ações em circulação correspondente a todas ações do emissor, com exceção das de titularidade do controlador, das pessoas a ele vinculadas, dos administradores do emissor e das ações mantidas em tesouraria, nos termos do artigo 62, da Instrução CVM 480/2009. 
Tabela 3 - Perfil dos Acionistas de Companhias sem Controle Majoritário ${ }^{85}$ (Grupo A)

\begin{tabular}{|c|c|c|c|c|c|c|c|c|c|c|c|}
\hline & & & COMPA & HIAS COM & ONTROLE I & NÃO MAJO & RITÁRIO ( & RUPO A) & & & \\
\hline & & & Acionistas & Pessoa Física & $\begin{array}{r}\text { Acionista } \\
\text { Jurí }\end{array}$ & $\begin{array}{l}\text { as Pessoa } \\
\text { ídica }\end{array}$ & $\begin{array}{l}\text { Inve } \\
\text { Instit }\end{array}$ & $\begin{array}{l}\text { tidores } \\
\text { ucionais }\end{array}$ & $\begin{array}{l}\text { Ações } \\
\text { em }\end{array}$ & & \\
\hline$\#$ & Denominação & $\begin{array}{l}\text { Total de } \\
\text { Acionistas }\end{array}$ & \begin{tabular}{c|}
$\begin{array}{c}\text { Número } \\
\text { de } \\
\text { Acionistas }\end{array}$ \\
\end{tabular} & $\begin{array}{l}\text { Proporção } \\
\text { entre } \\
\text { Acionistas }\end{array}$ & $\begin{array}{c}\text { Número } \\
\text { de } \\
\text { Acionistas }\end{array}$ & $\begin{array}{c}\text { Proporção } \\
\text { entre } \\
\text { Acionistas }\end{array}$ & $\begin{array}{c}\text { Número } \\
\text { de } \\
\text { Acionistas }\end{array}$ & $\begin{array}{c}\text { Proporção } \\
\text { entre } \\
\text { Acionistas }\end{array}$ & $\begin{array}{l}\text { Circu- } \\
\text { lação } \\
(\%)^{86}\end{array}$ & $\begin{array}{c}\text { Controle } \\
\text { Tabela } 2 \\
(\%)\end{array}$ & $\begin{array}{c}\text { Acionista } \\
\text { Tabela } 2 \\
(\%)\end{array}$ \\
\hline 10 & $\begin{array}{l}\text { Cyrela Commercial } \\
\text { Properties S.A. Empr. Part. }\end{array}$ & 900 & 790 & $87,78 \%$ & 60 & $6,67 \%$ & 50 & $5,56 \%$ & 27,28 & 43,227000 & 37,949900 \\
\hline 11 & Direcional Engenharia S.A. & 1.569 & 925 & $58,95 \%$ & 18 & $1,15 \%$ & 626 & $39,90 \%$ & 51,70 & 40,289729 & 40,289729 \\
\hline 12 & Equatorial Energia S.A. & 2.520 & 1.966 & $78,02 \%$ & 39 & $1,55 \%$ & 515 & $20,44 \%$ & 77,06 & 22,940000 & 22,940000 \\
\hline 13 & Hypermarcas S.A. & 7.916 & 6.629 & $83,74 \%$ & 232 & $2,93 \%$ & 1.055 & $13,33 \%$ & 52,86 & 40,631589 & 20,138641 \\
\hline 14 & Indústrias Romi S.A. & 1.130 & 1.007 & $89,12 \%$ & 12 & $1,06 \%$ & 111 & $9,82 \%$ & 100,00 & 37,858300 & 37,858300 \\
\hline 15 & $\begin{array}{l}\text { International Meal Company } \\
\text { Holdings S.A. }\end{array}$ & 989 & 367 & $37,11 \%$ & 8 & $0,81 \%$ & 614 & $62,08 \%$ & 60,10 & 39,750000 & 39,750000 \\
\hline 16 & Iochpe Maxion S.A. & 5.874 & 4.807 & $81,84 \%$ & 458 & $7,80 \%$ & 609 & $10,37 \%$ & 66,52 & 12,303381 & 6,766869 \\
\hline 17 & JBS S.A. & 9.145 & 8.129 & $88,89 \%$ & 99 & $1,08 \%$ & 917 & $10,03 \%$ & 53,87 & 43,598200 & 42,661000 \\
\hline 18 & Linx S.A. & 623 & 368 & $59,07 \%$ & 4 & $0,64 \%$ & 251 & $40,29 \%$ & 42,03 & 30,230000 & 14,800000 \\
\hline 19 & Localiza Rent a Car S.A. & 3.068 & 1.911 & $62,29 \%$ & 40 & $1,30 \%$ & 1.117 & $36,41 \%$ & 67,70 & 30,733107 & 9,000000 \\
\hline 20 & Magnesita Refratários S.A. & 8.612 & 7.578 & $87,99 \%$ & 401 & $4,66 \%$ & 633 & $7,35 \%$ & 58,37 & 41,220000 & 30,360000 \\
\hline 21 & Marfrig Alimentos S.A. & 6.232 & 5.370 & $86,17 \%$ & 75 & $1,20 \%$ & 787 & $12,63 \%$ & 66,41 & 33,118485 & 29,170349 \\
\hline 22 & $\begin{array}{l}\text { Mills Estrutura e Serviços de } \\
\text { Engenharia S.A. }\end{array}$ & 1.539 & 780 & $50,68 \%$ & 731 & $47,50 \%$ & 28 & $1,82 \%$ & 61,60 & 35,500000 & 13,900000 \\
\hline 23 & Minerva S.A. & 1.702 & 1.368 & $80,38 \%$ & 123 & $7,23 \%$ & 211 & $12,40 \%$ & 58,61 & 34,896932 & 34,896932 \\
\hline 24 & $\begin{array}{l}\text { MRV Engenharia e } \\
\text { Participações S.A. }\end{array}$ & 5.521 & 4.353 & $78,84 \%$ & 144 & $2,61 \%$ & 1.024 & $18,55 \%$ & 63,70 & 33,000000 & 33,000000 \\
\hline 25 & Qualicorp S.A. & 1.664 & 718 & $43,15 \%$ & 412 & $24,76 \%$ & 534 & $32,09 \%$ & 72,13 & 25,400162 & 25,400162 \\
\hline
\end{tabular}


Tabela 3 - Perfil dos Acionistas de Companhias sem Controle Majoritário ${ }^{85}$ (Grupo A)

\begin{tabular}{|c|c|c|c|c|c|c|c|c|c|c|c|}
\hline \multirow[b]{3}{*}{$\#$} & \multicolumn{11}{|c|}{ COMPANHIAS COM CONTROLE NÃO MAJORITÁRIO (GRUPO A) } \\
\hline & \multirow[b]{2}{*}{ Denominação } & \multirow[b]{2}{*}{$\begin{array}{l}\text { Total de } \\
\text { Acionistas }\end{array}$} & \multicolumn{2}{|c|}{ Acionistas Pessoa Física } & \multicolumn{2}{|c|}{$\begin{array}{c}\text { Acionistas Pessoa } \\
\text { Jurídica } \\
\end{array}$} & \multicolumn{2}{|c|}{$\begin{array}{c}\text { Investidores } \\
\text { Institucionais }\end{array}$} & \multirow{2}{*}{$\begin{array}{c}\text { Ações } \\
\text { em } \\
\text { Circu- } \\
\text { lação } \\
(\%)^{86}\end{array}$} & \multirow{2}{*}{$\begin{array}{c}\text { Total } \\
\text { Controle } \\
\text { Tabela } 2 \\
(\%)\end{array}$} & \multirow{2}{*}{$\begin{array}{c}\text { Maior } \\
\text { Acionista } \\
\text { Tabela } 2 \\
(\%)\end{array}$} \\
\hline & & & $\begin{array}{c}\begin{array}{c}\text { Número } \\
\text { de } \\
\text { Acionistas }\end{array} \\
\end{array}$ & $\begin{array}{l}\text { Proporção } \\
\text { entre } \\
\text { Acionistas }\end{array}$ & $\begin{array}{c}\begin{array}{c}\text { Número } \\
\text { de } \\
\text { Acionistas }\end{array} \\
\end{array}$ & $\begin{array}{l}\text { Proporção } \\
\text { entre } \\
\text { Acionistas }\end{array}$ & $\begin{array}{c}\text { Número } \\
\text { de } \\
\text { Acionistas }\end{array}$ & $\begin{array}{c}\text { Proporção } \\
\text { entre } \\
\text { Acionistas } \\
\end{array}$ & & & \\
\hline 26 & Raia Drogasil S.A. & 4.254 & 3.396 & $79,83 \%$ & 858 & $20,17 \%$ & 0 & $0,00 \%$ & 58,72 & 21,230502 & 10,799992 \\
\hline 27 & Rossi Residencial S.A. & 8.730 & 7.973 & $91,33 \%$ & 517 & $5,92 \%$ & 240 & $2,75 \%$ & 76,47 & 15,805467 & 8,736002 \\
\hline 28 & T4F Entretenimento S.A. & 706 & 548 & $77,62 \%$ & 81 & $11,47 \%$ & 77 & $10,91 \%$ & 61,80 & 40,440000 & 26,520000 \\
\hline
\end{tabular}

Tabela 3.1 - Perfil dos Acionistas de Companhias sem Controle Majoritário (Grupo B)

\begin{tabular}{|c|c|c|c|c|c|c|c|c|c|c|c|}
\hline \multicolumn{12}{|c|}{ COMPANHIAS SEM CONTROLE DEFINIDO (GRUPO B) } \\
\hline \multirow[b]{2}{*}{$\#$} & \multirow[b]{2}{*}{ Denominação } & \multirow{2}{*}{$\begin{array}{l}\text { Total de } \\
\text { Acionistas }\end{array}$} & \multicolumn{2}{|c|}{ Acionistas Pessoa Física } & \multicolumn{2}{|c|}{$\begin{array}{c}\text { Acionistas Pessoa } \\
\text { Jurídica } \\
\end{array}$} & \multicolumn{2}{|c|}{$\begin{array}{c}\text { Investidores } \\
\text { Institucionais }\end{array}$} & \multirow{2}{*}{\begin{tabular}{|c|} 
Ações em \\
Circu- \\
lação \\
$(\%)^{87}$
\end{tabular}} & \multirow{2}{*}{\begin{tabular}{|c|} 
Total \\
Controle \\
Tabela 2 \\
$(\%)$ \\
\end{tabular}} & \multirow{2}{*}{$\begin{array}{c}\text { Maior } \\
\text { Acionista } \\
\text { Tabela } 2 \\
(\%)\end{array}$} \\
\hline & & & $\begin{array}{c}\text { Número } \\
\text { de } \\
\text { Acionistas }\end{array}$ & $\begin{array}{l}\begin{array}{l}\text { Proporção } \\
\text { entre }\end{array} \\
\text { Acionistas }\end{array}$ & $\begin{array}{c}\text { Número } \\
\text { de } \\
\text { Acionistas }\end{array}$ & $\begin{array}{c}\text { Proporção } \\
\text { entre } \\
\text { Acionistas }\end{array}$ & $\begin{array}{c}\begin{array}{c}\text { Número } \\
\text { de } \\
\text { Acionistas }\end{array} \\
\end{array}$ & $\begin{array}{l}\text { Proporção } \\
\text { entre } \\
\text { Acionistas }\end{array}$ & & & \\
\hline 1 & $\begin{array}{l}\text { Anhanguera Educacional } \\
\text { Participações S.A }\end{array}$ & 3.566 & 1.677 & $47,03 \%$ & 1.224 & $34,32 \%$ & 665 & $18,65 \%$ & 95,975329 & 0 & 10,274981 \\
\hline 2 & Bematech S.A. & 2.522 & 2.294 & $90,96 \%$ & 95 & $3,77 \%$ & 133 & $5,27 \%$ & 74,200000 & 0 & 10,100000 \\
\hline 3 & $\begin{array}{l}\text { BM\&Fbovespa S.A. Bolsa } \\
\text { Valores Merc. Fut. }\end{array}$ & 58.870 & 55.277 & $93,90 \%$ & 1.336 & $2,27 \%$ & 2.257 & $3,83 \%$ & 97,440000 & 0 & 6,561100 \\
\hline
\end{tabular}

\footnotetext{
${ }^{87}$ Ações em circulação correspondente a todas ações do emissor, com exceção das de titularidade do controlador, das pessoas a ele vinculadas, dos administradores do emissor e das ações mantidas em tesouraria, nos termos do artigo 62, da Instrução CVM 480/2009.
} 
Tabela 3.1 - Perfil dos Acionistas de Companhias sem Controle Majoritário (Grupo B)

\begin{tabular}{|c|c|c|c|c|c|c|c|c|c|c|c|}
\hline \multicolumn{12}{|c|}{ COMPANHIAS SEM CONTROLE DEFINIDO (GRUPO B) } \\
\hline \multirow[b]{2}{*}{ \# } & \multirow[b]{2}{*}{ Denominação } & \multirow[b]{2}{*}{$\begin{array}{c}\text { Total de } \\
\text { Acionistas }\end{array}$} & \multicolumn{2}{|c|}{ Acionistas Pessoa Física } & \multicolumn{2}{|c|}{$\begin{array}{c}\text { Acionistas Pessoa } \\
\text { Jurídica }\end{array}$} & \multicolumn{2}{|c|}{$\begin{array}{c}\text { Investidores } \\
\text { Institucionais }\end{array}$} & \multirow{2}{*}{$\begin{array}{c}\text { Ações em } \\
\text { Circu- } \\
\text { lação } \\
(\%)^{87}\end{array}$} & \multirow{2}{*}{\begin{tabular}{|c|} 
Total \\
Controle \\
Tabela 2 \\
$(\%)$
\end{tabular}} & \multirow{2}{*}{$\begin{array}{c}\text { Maior } \\
\text { Acionista } \\
\text { Tabela } 2 \\
(\%)\end{array}$} \\
\hline & & & $\begin{array}{c}\text { Número } \\
\text { de } \\
\text { Acionistas }\end{array}$ & $\begin{array}{l}\text { Proporção } \\
\text { entre } \\
\text { Acionistas }\end{array}$ & $\begin{array}{c}\text { Número } \\
\text { de } \\
\text { Acionistas }\end{array}$ & $\begin{array}{l}\text { Proporção } \\
\text { entre } \\
\text { Acionistas }\end{array}$ & $\begin{array}{c}\text { Número } \\
\text { de } \\
\text { Acionistas }\end{array}$ & $\begin{array}{l}\text { Proporção } \\
\text { entre } \\
\text { Acionistas }\end{array}$ & & & \\
\hline 4 & BR Malls Participações S.A. & 6.323 & 4.431 & $70,08 \%$ & 870 & $13,76 \%$ & 1.022 & $16,16 \%$ & 94,353017 & 0 & 4,992784 \\
\hline 5 & BR Properties S.A. & 8.201 & 6.766 & $82,50 \%$ & 0 & $0,00 \%$ & 1.435 & $17,50 \%$ & 99,033000 & 0 & 24,494500 \\
\hline 6 & Brasil Pharma S.A. & 863 & 294 & $34,07 \%$ & 269 & $31,17 \%$ & 300 & $34,76 \%$ & 99,591000 & 0 & 15,284000 \\
\hline 7 & BRF S.A. & 25.717 & 22.474 & $87,39 \%$ & 2.175 & $8,46 \%$ & 1.068 & $4,15 \%$ & 98,630000 & 0 & 12,200000 \\
\hline 8 & $\begin{array}{l}\text { CETIP S.A. - Mercados } \\
\text { Organizados }\end{array}$ & 3.360 & 1.878 & $55,89 \%$ & 158 & $4,70 \%$ & 1.324 & $39,40 \%$ & 96,900000 & 0 & 12,180000 \\
\hline 9 & Cia Hering & 8.841 & 7.289 & $82,45 \%$ & 121 & $1,37 \%$ & 1.431 & $16,19 \%$ & 77,660000 & 0 & 7,270000 \\
\hline 10 & $\begin{array}{l}\text { CR2 Empreendimentos } \\
\text { Imobiliários S.A. }\end{array}$ & 272 & 209 & $76,84 \%$ & 42 & $15,44 \%$ & 21 & $7,72 \%$ & 77,394243 & 0 & 19,635891 \\
\hline 11 & $\begin{array}{l}\text { Diagnósticos da América } \\
\text { S.A. }\end{array}$ & 3.721 & 1.824 & $49,02 \%$ & 959 & $25,77 \%$ & 938 & $25,21 \%$ & 97,212645 & 0 & 12,028467 \\
\hline 12 & Embraer S.A. & 25.222 & 9.208 & $36,51 \%$ & 15.498 & $61,45 \%$ & 516 & $2,05 \%$ & 100,000000 & 0 & 8,850000 \\
\hline 13 & Estácio Participações S.A. & 1.622 & 1.050 & $64,73 \%$ & 406 & $25,03 \%$ & 166 & $10,23 \%$ & 98,682904 & 0 & 12,026076 \\
\hline 14 & Eternit S.A. & 7.315 & 6.944 & $94,93 \%$ & 86 & $1,18 \%$ & 285 & $3,90 \%$ & 84,418877 & 0 & 15,251397 \\
\hline 15 & $\begin{array}{l}\text { Even Construtora e } \\
\text { Incorporadora S.A. }\end{array}$ & 3.497 & 2.727 & $77,98 \%$ & 0 & $0,00 \%$ & 770 & $22,02 \%$ & 91,863092 & 0 & 5,160000 \\
\hline 16 & Gafisa S.A. & 16.243 & 15.607 & $96,08 \%$ & 298 & $1,83 \%$ & 338 & $2,08 \%$ & 100,000000 & 0 & 5,480000 \\
\hline 17 & $\begin{array}{l}\text { HRT Participações em } \\
\text { Petróleo S.A. }\end{array}$ & 4.181 & 3.637 & $86,99 \%$ & 544 & $13,01 \%$ & 0 & $0,00 \%$ & 96,850000 & 0 & 13,006192 \\
\hline 18 & Ideiasnet S.A. & 2.052 & 1.880 & $91,62 \%$ & 172 & $8,38 \%$ & 0 & $0,00 \%$ & 100,000000 & 0 & 14,995900 \\
\hline
\end{tabular}


Tabela 3.1 - Perfil dos Acionistas de Companhias sem Controle Majoritário (Grupo B)

\begin{tabular}{|c|c|c|c|c|c|c|c|c|c|c|c|}
\hline \multicolumn{12}{|c|}{ COMPANHIAS SEM CONTROLE DEFINIDO (GRUPO B) } \\
\hline \multirow[b]{2}{*}{ \# } & \multirow[b]{2}{*}{ Denominação } & \multirow[b]{2}{*}{$\begin{array}{c}\text { Total de } \\
\text { Acionistas }\end{array}$} & \multicolumn{2}{|c|}{ Acionistas Pessoa Física } & \multicolumn{2}{|c|}{$\begin{array}{c}\text { Acionistas Pessoa } \\
\text { Jurídica }\end{array}$} & \multicolumn{2}{|c|}{$\begin{array}{l}\text { Investidores } \\
\text { Institucionais }\end{array}$} & \multirow{2}{*}{$\begin{array}{c}\text { Ações em } \\
\text { Circu- } \\
\text { lação } \\
(\%)^{87}\end{array}$} & \multirow{2}{*}{\begin{tabular}{|c|} 
Total \\
Controle \\
Tabela 2 \\
$(\%)$
\end{tabular}} & \multirow{2}{*}{$\begin{array}{c}\text { Maior } \\
\text { Acionista } \\
\text { Tabela } 2 \\
(\%)\end{array}$} \\
\hline & & & $\begin{array}{c}\text { Número } \\
\text { de } \\
\text { Acionistas }\end{array}$ & $\begin{array}{l}\text { Proporção } \\
\text { entre } \\
\text { Acionistas }\end{array}$ & $\begin{array}{c}\text { Número } \\
\text { de } \\
\text { Acionistas }\end{array}$ & $\begin{array}{c}\text { Proporção } \\
\text { entre } \\
\text { Acionistas }\end{array}$ & $\begin{array}{c}\begin{array}{c}\text { Número } \\
\text { de } \\
\text { Acionistas }\end{array} \\
\end{array}$ & $\begin{array}{l}\text { Proporção } \\
\text { entre } \\
\text { Acionistas }\end{array}$ & & & \\
\hline 19 & Kroton Educacional S.A. & 4.053 & 1.667 & $41,13 \%$ & 1.193 & $29,43 \%$ & 1.193 & $29,43 \%$ & 76,150006 & 0 & 9,685365 \\
\hline 20 & $\begin{array}{l}\text { Log-in Logística Intermodal } \\
\text { S.A. }\end{array}$ & 3.070 & 2.660 & $86,64 \%$ & 205 & $6,68 \%$ & 205 & $6,68 \%$ & 93,210000 & 0 & 31,330000 \\
\hline 21 & Lojas Renner S.A. & 6.292 & 3.934 & $62,52 \%$ & 1.568 & $24,92 \%$ & 790 & $12,56 \%$ & 99,630000 & 0 & 14,290000 \\
\hline 22 & $\begin{array}{l}\text { LPS Brasil - Consultoria de } \\
\text { Imóveis S.A. }\end{array}$ & 841 & 396 & $47,09 \%$ & 211 & $25,09 \%$ & 234 & $27,82 \%$ & 100,000000 & 0 & 31,849857 \\
\hline 23 & Lupatech S.A. & 6.296 & 6.118 & $97,17 \%$ & 120 & $1,91 \%$ & 58 & $0,92 \%$ & 100,000000 & 0 & 31,135192 \\
\hline 24 & Metalfrio Solutions S.A. & 856 & 758 & $88,55 \%$ & 92 & $10,75 \%$ & 6 & $0,70 \%$ & 40,240000 & 0 & 27,940000 \\
\hline 25 & Paranapanema S.A. & 8.752 & 8.344 & $95,34 \%$ & 226 & $2,58 \%$ & 182 & $2,08 \%$ & 99,900000 & 0 & 23,960000 \\
\hline 26 & $\begin{array}{l}\text { PDG Realty S.A. Empreend. } \\
\text { e Participações }\end{array}$ & 20.116 & 17.809 & $88,53 \%$ & 213 & $1,06 \%$ & 2.094 & $10,41 \%$ & 97,070000 & 0 & 9,020000 \\
\hline 27 & $\begin{array}{l}\text { Restoque Comércio e } \\
\text { Confecções de Roupas S.A. }\end{array}$ & 1.543 & 1.131 & $73,30 \%$ & 328 & $21,26 \%$ & 84 & $5,44 \%$ & 100,000000 & 0 & 15,780000 \\
\hline 28 & Technos S.A. & 412 & 246 & $59,71 \%$ & 160 & $38,83 \%$ & 6 & $1,46 \%$ & 94,000000 & 0 & 37,440000 \\
\hline 29 & Tempo Participações S.A. & 649 & 531 & $81,82 \%$ & 7 & $1,08 \%$ & 111 & $17,10 \%$ & 100,000000 & 0 & 20,374962 \\
\hline 30 & Totvs S.A. & 4.641 & 2.824 & $60,85 \%$ & 999 & $21,53 \%$ & 818 & $17,63 \%$ & 68,496180 & 0 & 16,498458 \\
\hline 31 & Ultrapar Participações S.A. & 15.044 & 13.275 & $88,24 \%$ & 412 & $2,74 \%$ & 1.357 & $9,02 \%$ & 97,427301 & 0 & 23,665946 \\
\hline 32 & $\begin{array}{l}\text { Valid Soluções e Serv. Seg. } \\
\text { Meios Pag. Ident. S.A. }\end{array}$ & 2.844 & 1.951 & $68,60 \%$ & 296 & $10,41 \%$ & 597 & $20,99 \%$ & 100,000000 & 0 & 9,670000 \\
\hline 33 & Vanguarda Agro S.A. & 17.473 & 16.892 & $96,67 \%$ & 310 & $1,77 \%$ & 271 & $1,55 \%$ & 66,800000 & 0 & 19,520000 \\
\hline 34 & $\begin{array}{l}\text { Viver Incorporadora e } \\
\text { Construtora S.A. }\end{array}$ & 2.299 & 1.968 & $85,60 \%$ & 187 & $8,13 \%$ & 144 & $6,26 \%$ & {$[0,130000]$} & 0 & 39,960000 \\
\hline
\end{tabular}




\section{APÊNDICE D}

Tabela 4 - Acordos de Acionistas - Principais Cláusulas (Grupo A)

\begin{tabular}{|c|c|c|c|c|c|c|c|c|c|c|}
\hline \multirow{3}{*}{$\#$} & \multicolumn{10}{|c|}{ COMPANHIAS COM CONTROLE NÃO MAJORITÁRIO (GRUPO A) } \\
\hline & \multirow{2}{*}{ Companhia } & \multicolumn{2}{|c|}{$\begin{array}{c}\text { Exercício Direito de Voto e } \\
\text { Poder de Controle } \\
\text { (Item 15.5.d) }\end{array}$} & \multicolumn{2}{|c|}{$\begin{array}{c}\text { Indicação } \\
\text { Administradores } \\
\text { (Item 15.5.e) } \\
\end{array}$} & \multicolumn{4}{|c|}{$\begin{array}{l}\text { Restrições à Transferência de Ações } \\
\text { (Item 15.5.f) }\end{array}$} & \multirow{2}{*}{$\begin{array}{c}\text { Vinculação } \\
\text { Membros } \\
\text { Administração } \\
\text { (Item15.5.g) } \\
\end{array}$} \\
\hline & & $\begin{array}{l}\text { Exigência Voto } \\
\text { Afirmativo }\end{array}$ & $\begin{array}{l}\text { Reuniões } \\
\text { Prévias }\end{array}$ & $\begin{array}{c}\text { Membros } \\
\text { CA }\end{array}$ & $\begin{array}{l}\text { Membros } \\
\text { Diretoria }\end{array}$ & Lock-up & Preferência & $\begin{array}{c}\text { Tag } \\
\text { Along }\end{array}$ & $\begin{array}{c}\text { Drag } \\
\text { Along }\end{array}$ & \\
\hline 1 & Aliansce Shopping Centers S.A. & $\mathrm{X}$ & $\mathrm{X}$ & $\mathrm{X}$ & $\mathrm{X}$ & - & $\mathrm{X}$ & - & - & $\mathrm{X}$ \\
\hline 2 & ALL América Latina Logística S.A. & - & $\mathrm{X}$ & $\mathrm{X}$ & - & $X$ & $\mathrm{X}$ & - & - & $\mathrm{X}$ \\
\hline 3 & BHG S.A. - Brazil Hospitality Group & - & - & $\mathrm{X}$ & - & - & - & $\mathrm{X}$ & $\mathrm{X}$ & - \\
\hline 4 & Brasilagro - Cia. Bras. de Prop. Agrícolas & $\mathrm{n} / \mathrm{a}$ & $\mathrm{n} / \mathrm{a}$ & $\mathrm{n} / \mathrm{a}$ & $\mathrm{n} / \mathrm{a}$ & $\mathrm{n} / \mathrm{a}$ & $\mathrm{n} / \mathrm{a}$ & $\mathrm{n} / \mathrm{a}$ & $\mathrm{n} / \mathrm{a}$ & $\mathrm{n} / \mathrm{a}$ \\
\hline 5 & Brasil Brokers Participações S.A. & - & $\mathrm{X}$ & $X$ & - & $X$ & $\mathrm{X}$ & - & - & $\mathrm{X}$ \\
\hline 6 & Brasil Insurance Particip. e Administração S.A. & - & $X$ & - & - & $X$ & - & - & - & - \\
\hline 7 & Brookfield Incorporações S.A. & $\mathrm{X}$ & $\mathrm{X}$ & $\mathrm{X}$ & $\mathrm{X}$ & $X$ & - & - & - & $\mathrm{X}$ \\
\hline 8 & Companhia de Locação das Américas & - & $X$ & $\mathrm{X}$ & - & - & $X$ & - & - & $X$ \\
\hline 9 & Cyrela Brazil Realty S.A. Empreend. Part. & - & $\mathrm{X}$ & $\mathrm{X}$ & $X$ & $\mathrm{X}$ & $\mathrm{X}$ & $\mathrm{X}$ & $\mathrm{X}$ & $X$ \\
\hline 10 & Cyrela Commercial Properties S.A. Empr. Part. & $\mathrm{n} / \mathrm{a}$ & $\mathrm{n} / \mathrm{a}$ & $\mathrm{n} / \mathrm{a}$ & $\mathrm{n} / \mathrm{a}$ & $\mathrm{n} / \mathrm{a}$ & $\mathrm{n} / \mathrm{a}$ & $\mathrm{n} / \mathrm{a}$ & $\mathrm{n} / \mathrm{a}$ & $\mathrm{n} / \mathrm{a}$ \\
\hline 11 & Direcional Engenharia S.A. & $\mathrm{n} / \mathrm{a}$ & $\mathrm{n} / \mathrm{a}$ & $\mathrm{n} / \mathrm{a}$ & $\mathrm{n} / \mathrm{a}$ & $\mathrm{n} / \mathrm{a}$ & $\mathrm{n} / \mathrm{a}$ & $\mathrm{n} / \mathrm{a}$ & $\mathrm{n} / \mathrm{a}$ & $\mathrm{n} / \mathrm{a}$ \\
\hline 12 & Equatorial Energia S.A. & $\mathrm{n} / \mathrm{a}$ & $\mathrm{n} / \mathrm{a}$ & $\mathrm{n} / \mathrm{a}$ & $\mathrm{n} / \mathrm{a}$ & $\mathrm{n} / \mathrm{a}$ & $\mathrm{n} / \mathrm{a}$ & $\mathrm{n} / \mathrm{a}$ & $\mathrm{n} / \mathrm{a}$ & $\mathrm{n} / \mathrm{a}$ \\
\hline 13 & Hypermarcas S.A. & - & $X$ & $X$ & - & - & $X$ & - & - & - \\
\hline 14 & International Meal Company Holdings S.A. & $\mathrm{n} / \mathrm{a}$ & $\mathrm{n} / \mathrm{a}$ & $\mathrm{n} / \mathrm{a}$ & $\mathrm{n} / \mathrm{a}$ & $\mathrm{n} / \mathrm{a}$ & $\mathrm{n} / \mathrm{a}$ & $\mathrm{n} / \mathrm{a}$ & $\mathrm{n} / \mathrm{a}$ & $\mathrm{n} / \mathrm{a}$ \\
\hline
\end{tabular}


Tabela 4 - Acordos de Acionistas - Principais Cláusulas (Grupo A)

\begin{tabular}{|c|c|c|c|c|c|c|c|c|c|c|}
\hline \multirow[t]{2}{*}{$\#$} & \multirow[t]{2}{*}{ Companhia } & \multicolumn{2}{|c|}{$\begin{array}{l}\text { Exercício Direito de Voto e } \\
\text { Poder de Controle } \\
\text { (Item 15.5.d) }\end{array}$} & \multicolumn{2}{|c|}{$\begin{array}{c}\text { Indicação } \\
\text { Administradores } \\
\text { (Item 15.5.e) }\end{array}$} & \multicolumn{4}{|c|}{$\begin{array}{c}\text { Restrições à Transferência de Ações } \\
\text { (Item 15.5.f) }\end{array}$} & \multirow{2}{*}{$\begin{array}{l}\text { Vinculação } \\
\text { Membros } \\
\text { Administração } \\
\text { (Item15.5.g) }\end{array}$} \\
\hline & & $\begin{array}{l}\text { Exigência Voto } \\
\text { Afirmativo }\end{array}$ & $\begin{array}{l}\text { Reuniões } \\
\text { Prévias }\end{array}$ & $\begin{array}{c}\text { Membros } \\
\text { CA }\end{array}$ & $\begin{array}{l}\text { Membros } \\
\text { Diretoria }\end{array}$ & Lock-up & Preferência & $\begin{array}{c}\text { Tag } \\
\text { Along }\end{array}$ & $\begin{array}{c}\text { Drag } \\
\text { Along }\end{array}$ & \\
\hline 15 & Indústrias Romi S.A. & - & $X$ & - & - & - & - & - & - & - \\
\hline 16 & Iochpe Maxion S.A. & - & $\mathrm{X}$ & $\mathrm{X}$ & - & $\mathrm{X}$ & - & - & - & $\mathrm{X}$ \\
\hline 17 & JBS S.A. & $\mathrm{X}$ & - & $\mathrm{X}$ & - & - & - & - & - & $\mathrm{X}$ \\
\hline 18 & Linx S.A. & - & $\mathrm{X}$ & - & - & - & $\mathrm{X}$ & - & $X$ & - \\
\hline 19 & Localiza Rent a Car S.A. & $\mathrm{n} / \mathrm{a}$ & $\mathrm{n} / \mathrm{a}$ & $\mathrm{n} / \mathrm{a}$ & $\mathrm{n} / \mathrm{a}$ & $\mathrm{n} / \mathrm{a}$ & $\mathrm{n} / \mathrm{a}$ & $\mathrm{n} / \mathrm{a}$ & $\mathrm{n} / \mathrm{a}$ & $\mathrm{n} / \mathrm{a}$ \\
\hline 20 & Magnesita Refratários S.A. & - & $\mathrm{X}$ & $\mathrm{X}$ & - & - & $\mathrm{X}$ & $\mathrm{X}$ & - & $\mathrm{X}$ \\
\hline 21 & Marfrig Alimentos S.A. & - & - & $\mathrm{X}$ & - & - & $\mathrm{X}$ & - & - & - \\
\hline 22 & Mills Estrutura e Serviços de Engenharia S.A. & - & $\mathrm{X}$ & - & - & $\mathrm{X}$ & - & - & - & - \\
\hline 23 & Minerva S.A. & - & $\mathrm{X}$ & $\mathrm{X}$ & $\mathrm{X}$ & - & - & - & - & $\mathrm{X}$ \\
\hline 24 & MRV Engenharia e Participações S.A. & $\mathrm{n} / \mathrm{a}$ & $\mathrm{n} / \mathrm{a}$ & $\mathrm{n} / \mathrm{a}$ & $\mathrm{n} / \mathrm{a}$ & $\mathrm{n} / \mathrm{a}$ & $\mathrm{n} / \mathrm{a}$ & $\mathrm{n} / \mathrm{a}$ & $\mathrm{n} / \mathrm{a}$ & $\mathrm{n} / \mathrm{a}$ \\
\hline 25 & Qualicorp S.A. & $\mathrm{n} / \mathrm{a}$ & $\mathrm{n} / \mathrm{a}$ & $\mathrm{n} / \mathrm{a}$ & $\mathrm{n} / \mathrm{a}$ & $\mathrm{n} / \mathrm{a}$ & $\mathrm{n} / \mathrm{a}$ & $\mathrm{n} / \mathrm{a}$ & $\mathrm{n} / \mathrm{a}$ & $\mathrm{n} / \mathrm{a}$ \\
\hline 26 & Raia Drogasil S.A. & - & $\mathrm{X}$ & $\mathrm{X}$ & - & $\mathrm{X}$ & - & - & - & - \\
\hline 27 & Rossi Residencial S.A. & $X$ & $\mathrm{X}$ & $\mathrm{X}$ & - & $X$ & - & - & - & $\mathrm{X}$ \\
\hline 28 & T4F Entretenimento S.A. & - & $\mathrm{X}$ & $\mathrm{X}$ & - & $\mathrm{X}$ & $\mathrm{X}$ & $\mathrm{X}$ & $\mathrm{X}$ & $\mathrm{X}$ \\
\hline
\end{tabular}


Tabela 4.1 - Acordos de Acionistas - Principais Cláusulas (Grupo B)

\begin{tabular}{|c|c|c|c|c|c|c|c|c|c|c|c|}
\hline \multirow{3}{*}{ \# } & \multicolumn{11}{|c|}{ COMPANHIAS SEM CONTROLE DEFINIDO (GRUPO B) } \\
\hline & \multirow{2}{*}{ Companhia } & \multicolumn{2}{|c|}{$\begin{array}{l}\text { Exercício Direito de Voto e } \\
\text { Poder de Controle } \\
\text { (Item 15.5.d) }\end{array}$} & \multicolumn{2}{|c|}{$\begin{array}{c}\text { Indicação } \\
\text { Administradores } \\
\text { (Item 15.5e) }\end{array}$} & \multicolumn{4}{|c|}{$\begin{array}{c}\text { Restrições à Transferência de Ações } \\
\text { (Item 15.5.f) }\end{array}$} & \multirow{2}{*}{\multicolumn{2}{|c|}{$\begin{array}{c}\text { Vinculação } \\
\text { Membros } \\
\text { Administração } \\
\text { (Item15.5.g) }\end{array}$}} \\
\hline & & $\begin{array}{l}\text { Exigência Voto } \\
\text { Afirmativo }\end{array}$ & $\begin{array}{l}\text { Reuniões } \\
\text { Prévias }\end{array}$ & $\begin{array}{l}\text { Membros } \\
\text { CA }\end{array}$ & $\begin{array}{l}\text { Membros } \\
\text { Diretoria }\end{array}$ & Lock-up & $\begin{array}{c}\text { Preferênci } \\
\text { a }\end{array}$ & $\begin{array}{c}\text { Tag } \\
\text { Along }\end{array}$ & $\begin{array}{l}\text { Drag } \\
\text { Along }\end{array}$ & & \\
\hline 1 & Anhanguera Educacional Participações S.A & - & - & & - & - & - & $\mathrm{X}$ & $\mathrm{X}$ & $\mathrm{X}$ & - \\
\hline 2 & Bematech S.A. & $\mathrm{n} / \mathrm{a}$ & $\mathrm{n} / \mathrm{a}$ & & $/ \mathrm{a}$ & $\mathrm{n} / \mathrm{a}$ & $\mathrm{n} / \mathrm{a}$ & $\mathrm{n} / \mathrm{a}$ & $\mathrm{n} / \mathrm{a}$ & $\mathrm{n} / \mathrm{a}$ & $\mathrm{n} / \mathrm{a}$ \\
\hline 3 & BM\&Fbovespa S.A. Bolsa Valores Merc. Fut. & $\mathrm{n} / \mathrm{a}$ & $\mathrm{n} / \mathrm{a}$ & & /a & $\mathrm{n} / \mathrm{a}$ & $\mathrm{n} / \mathrm{a}$ & $\mathrm{n} / \mathrm{a}$ & $\mathrm{n} / \mathrm{a}$ & $\mathrm{n} / \mathrm{a}$ & $\mathrm{n} / \mathrm{a}$ \\
\hline 4 & BR Malls Participações S.A. & $\mathrm{n} / \mathrm{a}$ & $\mathrm{n} / \mathrm{a}$ & & $/ \mathrm{a}$ & $\mathrm{n} / \mathrm{a}$ & $\mathrm{n} / \mathrm{a}$ & $\mathrm{n} / \mathrm{a}$ & $\mathrm{n} / \mathrm{a}$ & $\mathrm{n} / \mathrm{a}$ & $\mathrm{n} / \mathrm{a}$ \\
\hline 5 & BR Properties S.A. & $\mathrm{n} / \mathrm{a}$ & $\mathrm{n} / \mathrm{a}$ & & /a & $\mathrm{n} / \mathrm{a}$ & $\mathrm{n} / \mathrm{a}$ & $\mathrm{n} / \mathrm{a}$ & $\mathrm{n} / \mathrm{a}$ & $\mathrm{n} / \mathrm{a}$ & $\mathrm{n} / \mathrm{a}$ \\
\hline 6 & Brasil Pharma S.A. & $\mathrm{n} / \mathrm{a}$ & $\mathrm{n} / \mathrm{a}$ & & /a & $\mathrm{n} / \mathrm{a}$ & $\mathrm{n} / \mathrm{a}$ & $\mathrm{n} / \mathrm{a}$ & $\mathrm{n} / \mathrm{a}$ & $\mathrm{n} / \mathrm{a}$ & $\mathrm{n} / \mathrm{a}$ \\
\hline 7 & BRF S.A. & $\mathrm{n} / \mathrm{a}$ & $\mathrm{n} / \mathrm{a}$ & & $/ \mathrm{a}$ & $\mathrm{n} / \mathrm{a}$ & $\mathrm{n} / \mathrm{a}$ & $\mathrm{n} / \mathrm{a}$ & $\mathrm{n} / \mathrm{a}$ & $\mathrm{n} / \mathrm{a}$ & $\mathrm{n} / \mathrm{a}$ \\
\hline 8 & CETIP S.A. - Mercados Organizados & $\mathrm{n} / \mathrm{a}$ & $\mathrm{n} / \mathrm{a}$ & & /a & $\mathrm{n} / \mathrm{a}$ & $\mathrm{n} / \mathrm{a}$ & $\mathrm{n} / \mathrm{a}$ & $\mathrm{n} / \mathrm{a}$ & $\mathrm{n} / \mathrm{a}$ & $\mathrm{n} / \mathrm{a}$ \\
\hline 9 & Cia Hering & $\mathrm{n} / \mathrm{a}$ & $\mathrm{n} / \mathrm{a}$ & & /a & $\mathrm{n} / \mathrm{a}$ & $\mathrm{n} / \mathrm{a}$ & $\mathrm{n} / \mathrm{a}$ & $\mathrm{n} / \mathrm{a}$ & $\mathrm{n} / \mathrm{a}$ & $\mathrm{n} / \mathrm{a}$ \\
\hline 10 & CR2 Empreendimentos Imobiliários S.A. & $\mathrm{n} / \mathrm{a}$ & $\mathrm{n} / \mathrm{a}$ & & /a & $\mathrm{n} / \mathrm{a}$ & $\mathrm{n} / \mathrm{a}$ & $\mathrm{n} / \mathrm{a}$ & $\mathrm{n} / \mathrm{a}$ & $\mathrm{n} / \mathrm{a}$ & $\mathrm{n} / \mathrm{a}$ \\
\hline 11 & Diagnósticos da América S.A. & $\mathrm{n} / \mathrm{a}$ & $\mathrm{n} / \mathrm{a}$ & & $/ \mathrm{a}$ & $\mathrm{n} / \mathrm{a}$ & $\mathrm{n} / \mathrm{a}$ & $\mathrm{n} / \mathrm{a}$ & $\mathrm{n} / \mathrm{a}$ & $\mathrm{n} / \mathrm{a}$ & $\mathrm{n} / \mathrm{a}$ \\
\hline 12 & Embraer S.A. & $\mathrm{n} / \mathrm{a}$ & $\mathrm{n} / \mathrm{a}$ & & $/ \mathrm{a}$ & $\mathrm{n} / \mathrm{a}$ & $\mathrm{n} / \mathrm{a}$ & $\mathrm{n} / \mathrm{a}$ & $\mathrm{n} / \mathrm{a}$ & $\mathrm{n} / \mathrm{a}$ & $\mathrm{n} / \mathrm{a}$ \\
\hline 13 & Estácio Participações S.A. & $\mathrm{n} / \mathrm{a}$ & $\mathrm{n} / \mathrm{a}$ & & $/ \mathrm{a}$ & $\mathrm{n} / \mathrm{a}$ & $\mathrm{n} / \mathrm{a}$ & $\mathrm{n} / \mathrm{a}$ & $\mathrm{n} / \mathrm{a}$ & $\mathrm{n} / \mathrm{a}$ & $\mathrm{n} / \mathrm{a}$ \\
\hline 14 & Eternit S.A. & $\mathrm{n} / \mathrm{a}$ & $\mathrm{n} / \mathrm{a}$ & & $/ \mathrm{a}$ & $\mathrm{n} / \mathrm{a}$ & $\mathrm{n} / \mathrm{a}$ & $\mathrm{n} / \mathrm{a}$ & $\mathrm{n} / \mathrm{a}$ & $\mathrm{n} / \mathrm{a}$ & $\mathrm{n} / \mathrm{a}$ \\
\hline 15 & Even Construtora e Incorporadora S.A. & - & - & & $X$ & - & - & - & - & - & - \\
\hline 16 & Gafisa S.A. & $\mathrm{n} / \mathrm{a}$ & $\mathrm{n} / \mathrm{a}$ & & $/ \mathrm{a}$ & $\mathrm{n} / \mathrm{a}$ & $\mathrm{n} / \mathrm{a}$ & $\mathrm{n} / \mathrm{a}$ & $\mathrm{n} / \mathrm{a}$ & $\mathrm{n} / \mathrm{a}$ & $\mathrm{n} / \mathrm{a}$ \\
\hline 17 & HRT Participações em Petróleo S.A. & $\mathrm{n} / \mathrm{a}$ & $\mathrm{n} / \mathrm{a}$ & & /a & $\mathrm{n} / \mathrm{a}$ & $\mathrm{n} / \mathrm{a}$ & $\mathrm{n} / \mathrm{a}$ & $\mathrm{n} / \mathrm{a}$ & $\mathrm{n} / \mathrm{a}$ & $\mathrm{n} / \mathrm{a}$ \\
\hline
\end{tabular}


Tabela 4.1 - Acordos de Acionistas - Principais Cláusulas (Grupo B)

\begin{tabular}{|c|c|c|c|c|c|c|c|c|c|c|c|}
\hline \multirow{3}{*}{ \# } & \multicolumn{11}{|c|}{ COMPANHIAS SEM CONTROLE DEFINIDO (GRUPO B) } \\
\hline & \multirow{2}{*}{ Companhia } & \multicolumn{2}{|c|}{$\begin{array}{l}\text { Exercício Direito de Voto e } \\
\text { Poder de Controle } \\
\text { (Item 15.5.d) }\end{array}$} & \multicolumn{2}{|c|}{$\begin{array}{c}\text { Indicação } \\
\text { Administradores } \\
\text { (Item 15.5e) }\end{array}$} & \multicolumn{4}{|c|}{$\begin{array}{c}\text { Restrições à Transferência de Ações } \\
\text { (Item 15.5.f) }\end{array}$} & \multirow{2}{*}{\multicolumn{2}{|c|}{$\begin{array}{c}\text { Vinculação } \\
\text { Membros } \\
\text { Administração } \\
\text { (Item15.5.g) }\end{array}$}} \\
\hline & & $\begin{array}{l}\text { Exigência Voto } \\
\text { Afirmativo }\end{array}$ & $\begin{array}{l}\text { Reuniões } \\
\text { Prévias }\end{array}$ & $\begin{array}{l}\text { Membros } \\
\text { CA }\end{array}$ & $\begin{array}{l}\text { Membros } \\
\text { Diretoria }\end{array}$ & Lock-up & $\begin{array}{l}\text { Preferênci } \\
\text { a }\end{array}$ & $\begin{array}{c}\text { Tag } \\
\text { Along }\end{array}$ & $\begin{array}{l}\text { Drag } \\
\text { Along }\end{array}$ & & \\
\hline 18 & Ideiasnet S.A. & $\mathrm{n} / \mathrm{a}$ & $\mathrm{n} / \mathrm{a}$ & & /a & $\mathrm{n} / \mathrm{a}$ & $\mathrm{n} / \mathrm{a}$ & $\mathrm{n} / \mathrm{a}$ & $\mathrm{n} / \mathrm{a}$ & $\mathrm{n} / \mathrm{a}$ & $\mathrm{n} / \mathrm{a}$ \\
\hline 19 & Kroton Educacional S.A. & - & - & & $x$ & - & - & - & $X$ & - & - \\
\hline 20 & Log-in Logística Intermodal S.A. & $\mathrm{n} / \mathrm{a}$ & $\mathrm{n} / \mathrm{a}$ & & /a & $\mathrm{n} / \mathrm{a}$ & $\mathrm{n} / \mathrm{a}$ & $\mathrm{n} / \mathrm{a}$ & $\mathrm{n} / \mathrm{a}$ & $\mathrm{n} / \mathrm{a}$ & $\mathrm{n} / \mathrm{a}$ \\
\hline 21 & Lojas Renner S.A. & $\mathrm{n} / \mathrm{a}$ & $\mathrm{n} / \mathrm{a}$ & & $/ \mathrm{a}$ & $\mathrm{n} / \mathrm{a}$ & $\mathrm{n} / \mathrm{a}$ & $\mathrm{n} / \mathrm{a}$ & $\mathrm{n} / \mathrm{a}$ & $\mathrm{n} / \mathrm{a}$ & $\mathrm{n} / \mathrm{a}$ \\
\hline 22 & LPS Brasil - Consultoria de Imóveis S.A. & $\mathrm{n} / \mathrm{a}$ & $\mathrm{n} / \mathrm{a}$ & & $/ \mathrm{a}$ & $\mathrm{n} / \mathrm{a}$ & $\mathrm{n} / \mathrm{a}$ & $\mathrm{n} / \mathrm{a}$ & $\mathrm{n} / \mathrm{a}$ & $\mathrm{n} / \mathrm{a}$ & $\mathrm{n} / \mathrm{a}$ \\
\hline 23 & Lupatech S.A. & $\mathrm{n} / \mathrm{a}$ & $\mathrm{n} / \mathrm{a}$ & & /a & $\mathrm{n} / \mathrm{a}$ & $\mathrm{n} / \mathrm{a}$ & $\mathrm{n} / \mathrm{a}$ & $\mathrm{n} / \mathrm{a}$ & $\mathrm{n} / \mathrm{a}$ & $\mathrm{n} / \mathrm{a}$ \\
\hline 24 & Metalfrio Solutions S.A. & $\mathrm{n} / \mathrm{a}$ & $\mathrm{n} / \mathrm{a}$ & & /a & $\mathrm{n} / \mathrm{a}$ & $\mathrm{n} / \mathrm{a}$ & $\mathrm{n} / \mathrm{a}$ & $\mathrm{n} / \mathrm{a}$ & $\mathrm{n} / \mathrm{a}$ & $\mathrm{n} / \mathrm{a}$ \\
\hline 25 & Paranapanema S.A. & $\mathrm{n} / \mathrm{a}$ & $\mathrm{n} / \mathrm{a}$ & & $/ \mathrm{a}$ & $\mathrm{n} / \mathrm{a}$ & $\mathrm{n} / \mathrm{a}$ & $\mathrm{n} / \mathrm{a}$ & $\mathrm{n} / \mathrm{a}$ & $\mathrm{n} / \mathrm{a}$ & $\mathrm{n} / \mathrm{a}$ \\
\hline 26 & PDG Realty S.A. Empreend. e Participações & $\mathrm{n} / \mathrm{a}$ & $\mathrm{n} / \mathrm{a}$ & & /a & $\mathrm{n} / \mathrm{a}$ & $\mathrm{n} / \mathrm{a}$ & $\mathrm{n} / \mathrm{a}$ & $\mathrm{n} / \mathrm{a}$ & $\mathrm{n} / \mathrm{a}$ & $\mathrm{n} / \mathrm{a}$ \\
\hline 27 & $\begin{array}{l}\text { Restoque Comércio e Confecções de Roupas } \\
\text { S.A. }\end{array}$ & $\mathrm{n} / \mathrm{a}$ & $\mathrm{n} / \mathrm{a}$ & & /a & $\mathrm{n} / \mathrm{a}$ & $\mathrm{n} / \mathrm{a}$ & $\mathrm{n} / \mathrm{a}$ & $\mathrm{n} / \mathrm{a}$ & $\mathrm{n} / \mathrm{a}$ & $\mathrm{n} / \mathrm{a}$ \\
\hline 28 & Technos S.A. & - & - & & - & - & $X$ & - & - & - & - \\
\hline 29 & Tempo Participações S.A. & $\mathrm{n} / \mathrm{a}$ & $\mathrm{n} / \mathrm{a}$ & & /a & $\mathrm{n} / \mathrm{a}$ & $\mathrm{n} / \mathrm{a}$ & $\mathrm{n} / \mathrm{a}$ & $\mathrm{n} / \mathrm{a}$ & $\mathrm{n} / \mathrm{a}$ & $\mathrm{n} / \mathrm{a}$ \\
\hline 30 & Totvs S.A. & $\mathrm{n} / \mathrm{a}$ & $\mathrm{n} / \mathrm{a}$ & & /a & $\mathrm{n} / \mathrm{a}$ & $\mathrm{n} / \mathrm{a}$ & $\mathrm{n} / \mathrm{a}$ & $\mathrm{n} / \mathrm{a}$ & $\mathrm{n} / \mathrm{a}$ & $\mathrm{n} / \mathrm{a}$ \\
\hline 31 & Ultrapar Participações S.A. & - & $X$ & & - & - & - & - & - & - & - \\
\hline 32 & $\begin{array}{l}\text { Valid Soluções e Serv. Seg. Meios Pag. Ident. } \\
\text { S.A. }\end{array}$ & $\mathrm{n} / \mathrm{a}$ & $\mathrm{n} / \mathrm{a}$ & & /a & $\mathrm{n} / \mathrm{a}$ & $\mathrm{n} / \mathrm{a}$ & $\mathrm{n} / \mathrm{a}$ & $\mathrm{n} / \mathrm{a}$ & $\mathrm{n} / \mathrm{a}$ & $\mathrm{n} / \mathrm{a}$ \\
\hline 33 & Vanguarda Agro S.A. & $\mathrm{n} / \mathrm{a}$ & $\mathrm{n} / \mathrm{a}$ & & $/ \mathrm{a}$ & $\mathrm{n} / \mathrm{a}$ & $\mathrm{n} / \mathrm{a}$ & $\mathrm{n} / \mathrm{a}$ & $\mathrm{n} / \mathrm{a}$ & $\mathrm{n} / \mathrm{a}$ & $\mathrm{n} / \mathrm{a}$ \\
\hline 34 & Viver Incorporadora e Construtora S.A. & $\mathrm{n} / \mathrm{a}$ & $\mathrm{n} / \mathrm{a}$ & & $/ \mathrm{a}$ & $\mathrm{n} / \mathrm{a}$ & $\mathrm{n} / \mathrm{a}$ & $\mathrm{n} / \mathrm{a}$ & $\mathrm{n} / \mathrm{a}$ & $\mathrm{n} / \mathrm{a}$ & $\mathrm{n} / \mathrm{a}$ \\
\hline
\end{tabular}


APÊNDICE E

Tabela 5 - Cláusulas de Proteção à Dispersão Acionária

\begin{tabular}{|c|c|c|c|c|c|c|c|c|c|c|}
\hline$\#$ & Companhia & $\begin{array}{l}\text { ES com } \\
\text { Pílula de } \\
\text { Veneno }\end{array}$ & $\begin{array}{l}\text { Percen- } \\
\text { tual de } \\
\text { Disparo }\end{array}$ & $\begin{array}{c}\text { Total } \\
\text { Controle } \\
\text { Tabela } 2 \\
(\%)\end{array}$ & $\begin{array}{c}\text { Maior } \\
\text { Acionista } \\
\text { Tabela } 2 \\
(\%)\end{array}$ & $\begin{array}{c}\text { Fixação } \\
\text { de } \\
\text { Preço } \\
\text { Mínimo }\end{array}$ & $\begin{array}{c}\text { Exceção } \\
\text { para } \\
\text { Acionistas } \\
\text { Anteriores } \\
\text { Ao Registro } \\
\text { na CVM }\end{array}$ & $\begin{array}{c}\text { Penalidades pelo } \\
\text { Descumprimento da } \\
\text { Obrigação de } \\
\text { Realização da OPA }\end{array}$ & $\begin{array}{l}\text { AG ou } \\
\text { RCA } \\
\text { Poderá } \\
\text { Dispensar } \\
\text { OPA? }\end{array}$ & $\begin{array}{c}\text { Previsão Cláusula } \\
\text { Pétrea - Penalidade } \\
\text { Supressão }\end{array}$ \\
\hline 1 & $\begin{array}{l}\text { Aliansce } \\
\text { Shopping } \\
\text { Centers S.A. }\end{array}$ & Sim & $\geq 30 \%$ & 37,40588 & 28,030663 & Sim & Sim & $\begin{array}{l}\text { (i) perda de direitos de } \\
\text { acionista mediante deliberação } \\
\text { de Assembleia Geral } \\
\text { Extraordinária convocada para } \\
\text { este fim; e (ii) responsabilidade } \\
\text { por perdas e danos incorridos } \\
\text { pelos demais acionistas }\end{array}$ & Sim & Não \\
\hline 2 & $\begin{array}{l}\text { ALL América } \\
\text { Latina Logística } \\
\text { S.A. }\end{array}$ & Sim & $>20 \%$ & 22,661992 & 23,510000 & Sim & Sim & $\begin{array}{l}\text { perda de direito de voto } \\
\text { mediante deliberação de } \\
\text { Assembleia Geral } \\
\text { Extraordinária convocada para } \\
\text { este fim }\end{array}$ & Sim & Não \\
\hline 3 & $\begin{array}{l}\text { BHG S.A. - } \\
\text { Brazil } \\
\text { Hospitality } \\
\text { Group }\end{array}$ & Sim & $\geq 35 \%$ & 30,175700 & 29,507800 & Sim & Não & $\begin{array}{l}\text { (i) perda de direitos de } \\
\text { acionista mediante deliberação } \\
\text { de Assembleia Geral } \\
\text { Extraordinária convocada para } \\
\text { este fim; e (ii) responsabilidade } \\
\text { por perdas e danos incorridos } \\
\text { pelos demais acionistas }\end{array}$ & Não & $\begin{array}{l}\text { Sim - Obrigatoriedade } \\
\text { de realização de OPA } \\
\text { na hipótese de voto } \\
\text { favorável à alteração } \\
\text { ou exclusão da } \\
\text { respectiva cláusula do } \\
\text { ES }\end{array}$ \\
\hline
\end{tabular}


Tabela 5 - Cláusulas de Proteção à Dispersão Acionária

\begin{tabular}{|c|c|c|c|c|c|c|c|c|c|c|}
\hline$\#$ & Companhia & $\begin{array}{l}\text { ES com } \\
\text { Pílula de } \\
\text { Veneno }\end{array}$ & $\begin{array}{l}\text { Percen- } \\
\text { tual de } \\
\text { Disparo }\end{array}$ & $\begin{array}{c}\text { Total } \\
\text { Controle } \\
\text { Tabela } 2 \\
(\%)\end{array}$ & $\begin{array}{l}\text { Maior } \\
\text { Acionista } \\
\text { Tabela } 2 \\
(\%)\end{array}$ & 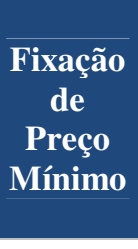 & $\begin{array}{c}\text { Exceção } \\
\text { para } \\
\text { Acionistas } \\
\text { Anteriores } \\
\text { Ao Registro } \\
\text { na CVM }\end{array}$ & $\begin{array}{c}\text { Penalidades pelo } \\
\text { Descumprimento da } \\
\text { Obrigação de } \\
\text { Realização da OPA }\end{array}$ & \begin{tabular}{|c} 
AG ou \\
RCA \\
Poderá \\
Dispensar \\
OPA?
\end{tabular} & $\begin{array}{l}\text { Previsão Cláusula } \\
\text { Pétrea - Penalidade } \\
\text { Supressão }\end{array}$ \\
\hline 4 & $\begin{array}{l}\text { Brasil Brokers } \\
\text { Participações } \\
\text { S.A. }\end{array}$ & Sim & $\geq 20 \%$ & 16,446142 & 10,047441 & Sim & Sim & $\begin{array}{l}\text { (i) perda de direitos de } \\
\text { acionista mediante deliberação } \\
\text { de Assembleia Geral } \\
\text { Extraordinária convocada para } \\
\text { este fim; e (ii) responsabilidade } \\
\text { por perdas e danos incorridos } \\
\text { pelos demais acionistas }\end{array}$ & Não & Não \\
\hline 5 & $\begin{array}{l}\text { Brasil Insurance } \\
\text { Particip. e } \\
\text { Administração } \\
\text { S.A. }\end{array}$ & Sim & $\geq 20 \%$ & 6,480000 & 6,480000 & Sim & Sim & $\begin{array}{l}\text { (i) perda de direitos de } \\
\text { acionista mediante deliberação } \\
\text { de Assembleia Geral } \\
\text { Extraordinária convocada para } \\
\text { este fim; e (ii) responsabilidade } \\
\text { por perdas e danos incorridos } \\
\text { pelos demais acionistas }\end{array}$ & Sim & Não \\
\hline 6 & $\begin{array}{l}\text { Brookfield } \\
\text { Incorporações } \\
\text { S.A. }\end{array}$ & N/A & N/A & N/A & N/A & N/A & N/A & N/A & N/A & N/A \\
\hline 7 & $\begin{array}{l}\text { Companhia de } \\
\text { Locação das } \\
\text { Américas }\end{array}$ & Sim & $\geq 25 \%$ & 47,020000 & 23,510000 & Sim & Sim & $\begin{array}{l}\text { perda de direito de voto } \\
\text { mediante deliberação de } \\
\text { Assembleia Geral Extraordinária } \\
\text { convocada para este fim }\end{array}$ & Sim & Não \\
\hline 8 & $\begin{array}{l}\text { Cyrela Brazil } \\
\text { Realty S.A. } \\
\text { Empreend. Part. }\end{array}$ & N/A & N/A & N/A & N/A & N/A & N/A & N/A & N/A & N/A \\
\hline
\end{tabular}


Tabela 5 - Cláusulas de Proteção à Dispersão Acionária

\begin{tabular}{|c|c|c|c|c|c|c|c|c|c|c|}
\hline$\#$ & Companhia & $\begin{array}{l}\text { ES com } \\
\text { Pílula de } \\
\text { Veneno }\end{array}$ & $\begin{array}{l}\text { Percen- } \\
\text { tual de } \\
\text { Disparo }\end{array}$ & $\begin{array}{c}\text { Total } \\
\text { Controle } \\
\text { Tabela } 2 \\
(\%)\end{array}$ & $\begin{array}{c}\text { Maior } \\
\text { Acionista } \\
\text { Tabela } 2 \\
(\%)\end{array}$ & $\begin{array}{c}\text { Fixação } \\
\text { de } \\
\text { Preço } \\
\text { Mínimo }\end{array}$ & $\begin{array}{c}\text { Exceção } \\
\text { para } \\
\text { Acionistas } \\
\text { Anteriores } \\
\text { Ao Registro } \\
\text { na CVM }\end{array}$ & $\begin{array}{c}\text { Penalidades pelo } \\
\text { Descumprimento da } \\
\text { Obrigação de } \\
\text { Realização da OPA }\end{array}$ & $\begin{array}{c}\text { AG ou } \\
\text { RCA } \\
\text { Poderá } \\
\text { Dispensar } \\
\text { OPA? }\end{array}$ & \begin{tabular}{|c|} 
Previsão Cláusula \\
Pétrea - Penalidade \\
Supressão
\end{tabular} \\
\hline 9 & $\begin{array}{l}\text { Hypermarcas } \\
\text { S.A. }\end{array}$ & N/A & N/A & N/A & N/A & N/A & N/A & N/A & N/A & N/A \\
\hline 10 & $\begin{array}{l}\text { Indústrias Romi } \\
\text { S.A. }\end{array}$ & Sim & $\geq 15 \%$ & 37,858300 & 37,858300 & Sim & Sim & $\begin{array}{l}\text { (i) perda de direitos de } \\
\text { acionista mediante deliberação } \\
\text { de Assembleia Geral } \\
\text { Extraordinária convocada para } \\
\text { este fim; e (ii) responsabilidade } \\
\text { por perdas e danos incorridos } \\
\text { pelos demais acionistas }\end{array}$ & Não & $\begin{array}{l}\text { Sim - Obrigatoriedade } \\
\text { de realização de OPA } \\
\text { na hipótese de voto } \\
\text { favorável à alteração } \\
\text { ou exclusão da } \\
\text { respectiva cláusula do } \\
\text { ES. }\end{array}$ \\
\hline 11 & $\begin{array}{l}\text { Iochpe Maxion } \\
\text { S.A. }\end{array}$ & Sim & $\geq 15 \%$ & 12,303381 & 6,766869 & Sim & Sim & $\begin{array}{l}\text { (i) perda de direitos de } \\
\text { acionista mediante deliberação } \\
\text { de Assembleia Geral } \\
\text { Extraordinária convocada para } \\
\text { este fim; e (ii) responsabilidade } \\
\text { por perdas e danos incorridos } \\
\text { pelos demais acionistas }\end{array}$ & Não & $\begin{array}{l}\text { Sim - Obrigatoriedade } \\
\text { de realização de OPA } \\
\text { na hipótese de voto } \\
\text { favorável à alteração } \\
\text { ou exclusão da } \\
\text { respectiva cláusula do } \\
\text { ES. }\end{array}$ \\
\hline 12 & JBS S.A. & Sim & $\geq 20 \%$ & 43,598200 & 42,661000 & Sim & Não & $\begin{array}{l}\text { (i) perda de direitos de } \\
\text { acionista mediante deliberação } \\
\text { de Assembleia Geral } \\
\text { Extraordinária convocada para } \\
\text { este fim; e (ii) responsabilidade } \\
\text { por perdas e danos incorridos } \\
\text { pelos demais acionistas }\end{array}$ & Não & Não \\
\hline
\end{tabular}


Tabela 5 - Cláusulas de Proteção à Dispersão Acionária

\begin{tabular}{|c|c|c|c|c|c|c|c|c|c|c|}
\hline \# & Companhia & $\begin{array}{l}\text { ES com } \\
\text { Pílula de } \\
\text { Veneno }\end{array}$ & $\begin{array}{l}\text { Percen- } \\
\text { tual de } \\
\text { Disparo }\end{array}$ & $\begin{array}{c}\text { Total } \\
\text { Controle } \\
\text { Tabela } 2 \\
(\%)\end{array}$ & $\begin{array}{c}\text { Maior } \\
\text { Acionista } \\
\text { Tabela } 2 \\
(\%)\end{array}$ & $\begin{array}{c}\text { Fixação } \\
\text { de } \\
\text { Preço } \\
\text { Mínimo }\end{array}$ & $\begin{array}{c}\text { Exceção } \\
\text { para } \\
\text { Acionistas } \\
\text { Anteriores } \\
\text { Ao Registro } \\
\text { na CVM }\end{array}$ & $\begin{array}{c}\text { Penalidades pelo } \\
\text { Descumprimento da } \\
\text { Obrigação de } \\
\text { Realização da OPA }\end{array}$ & $\begin{array}{c}\text { AG ou } \\
\text { RCA } \\
\text { Poderá } \\
\text { Dispensar } \\
\text { OPA? }\end{array}$ & $\begin{array}{l}\text { Previsão Cláusula } \\
\text { Pétrea - Penalidade } \\
\text { Supressão }\end{array}$ \\
\hline 13 & Linx S.A. & Sim & $\geq 25 \%$ & 30,230000 & 14,800000 & Sim & Sim & $\begin{array}{l}\text { (i) perda de direitos de } \\
\text { acionista mediante deliberação } \\
\text { de Assembleia Geral } \\
\text { Extraordinária convocada para } \\
\text { este fim; e (ii) responsabilidade } \\
\text { por perdas e danos incorridos } \\
\text { pelos demais acionistas }\end{array}$ & Não & Não \\
\hline 14 & $\begin{array}{l}\text { Magnesita } \\
\text { Refratários S.A. }\end{array}$ & N/A & N/A & N/A & N/A & N/A & N/A & N/A & N/A & N/A \\
\hline 15 & $\begin{array}{l}\text { Marfrig } \\
\text { Alimentos S.A. }\end{array}$ & N/A & N/A & N/A & N/A & N/A & N/A & N/A & N/A & N/A \\
\hline 16 & $\begin{array}{l}\text { Mills Estrutura e } \\
\text { Serviços de } \\
\text { Engenharia S.A. }\end{array}$ & Sim & $\geq 20 \%$ & 35,500000 & 13,900000 & Sim & Não & $\begin{array}{l}\text { perda de direito de voto } \\
\text { mediante deliberação de } \\
\text { Assembleia Geral } \\
\text { Extraordinária convocada para } \\
\text { este fim }\end{array}$ & Sim & Não \\
\hline 17 & Minerva S.A. & Sim & $\geq 20 \%$ & 34,896932 & 34,896932 & Sim & Sim & $\begin{array}{l}\text { (i) perda de direitos de } \\
\text { acionista mediante deliberação } \\
\text { de Assembleia Geral } \\
\text { Extraordinária convocada para } \\
\text { este fim; e (ii) responsabilidade } \\
\text { por perdas e danos incorridos } \\
\text { pelos demais acionistas }\end{array}$ & Sim & Não \\
\hline
\end{tabular}


Tabela 5 - Cláusulas de Proteção à Dispersão Acionária

\begin{tabular}{|c|c|c|c|c|c|c|c|c|c|c|}
\hline$\#$ & Companhia & $\begin{array}{l}\text { ES com } \\
\text { Pílula de } \\
\text { Veneno }\end{array}$ & $\begin{array}{l}\text { Percen- } \\
\text { tual de } \\
\text { Disparo }\end{array}$ & $\begin{array}{c}\text { Total } \\
\text { Controle } \\
\text { Tabela } 2 \\
(\%)\end{array}$ & $\begin{array}{c}\text { Maior } \\
\text { Acionista } \\
\text { Tabela } 2 \\
(\%)\end{array}$ & $\begin{array}{c}\text { Fixação } \\
\text { de } \\
\text { Preço } \\
\text { Mínimo }\end{array}$ & $\begin{array}{c}\text { Exceção } \\
\text { para } \\
\text { Acionistas } \\
\text { Anteriores } \\
\text { Ao Registro } \\
\text { na CVM }\end{array}$ & $\begin{array}{c}\text { Penalidades pelo } \\
\text { Descumprimento da } \\
\text { Obrigação de } \\
\text { Realização da OPA }\end{array}$ & $\begin{array}{c}\text { AG ou } \\
\text { RCA } \\
\text { Poderá } \\
\text { Dispensar } \\
\text { OPA? }\end{array}$ & \begin{tabular}{|c|} 
Previsão Cláusula \\
Pétrea - Penalidade \\
Supressão
\end{tabular} \\
\hline 18 & $\begin{array}{l}\text { Raia Drogasil } \\
\text { S.A. }\end{array}$ & Sim & $\geq 20 \%$ & 21,230502 & 10,799992 & Sim & Sim & $\begin{array}{l}\text { (i) perda de direitos de } \\
\text { acionista mediante deliberação } \\
\text { de Assembleia Geral } \\
\text { Extraordinária convocada para } \\
\text { este fim; e (ii) responsabilidade } \\
\text { por perdas e danos incorridos } \\
\text { pelos demais acionistas }\end{array}$ & Sim & Não \\
\hline 19 & $\begin{array}{l}\text { Rossi } \\
\text { Residencial S.A. }\end{array}$ & Sim & $\geq 15 \%$ & 15,805467 & 8,736002 & Sim & Não & $\begin{array}{l}\text { (i) perda de direitos de } \\
\text { acionista mediante deliberação } \\
\text { de Assembleia Geral } \\
\text { Extraordinária convocada para } \\
\text { este fim; e (ii) responsabilidade } \\
\text { por perdas e danos incorridos } \\
\text { pelos demais acionistas }\end{array}$ & Sim & Não \\
\hline 20 & $\begin{array}{l}\text { T4F } \\
\text { Entretenimento } \\
\text { S.A. }\end{array}$ & Sim & $\geq 20 \%$ & 40,440000 & 26,520000 & Sim & Sim & $\begin{array}{l}\text { perda de direito de voto } \\
\text { mediante deliberação de } \\
\text { Assembleia Geral } \\
\text { Extraordinária convocada para } \\
\text { este fim }\end{array}$ & Sim & Não \\
\hline
\end{tabular}


APÊNDICE F

Tabela 6 - Assembleias Gerais Ordinárias (2011)

\begin{tabular}{|c|c|c|c|c|c|c|c|c|}
\hline & $\begin{array}{c}\text { Companhias do } \\
\text { Grupo A }\end{array}$ & $\begin{array}{l}\text { Quórum } \\
\text { Instalação }\end{array}$ & $\begin{array}{c}1^{\mathrm{a}} \\
\text { Convocação }\end{array}$ & $\begin{array}{c}2^{\mathrm{a}} \\
\text { Convocação }\end{array}$ & $\begin{array}{l}\text { Aprovação } \\
\text { Contas }\end{array}$ & $\begin{array}{l}\text { Eleição } \\
\text { Adm. }\end{array}$ & Remuneração & $\begin{array}{l}\text { Detalhamento } \\
\text { dos Votos }\end{array}$ \\
\hline 1 & $\begin{array}{l}\text { Aliansce Shopping } \\
\text { Centers S.A. }\end{array}$ & $>2 / 3$ & Sim & Não & Unanimidade & Maioria & Unanimidade & - \\
\hline 2 & $\begin{array}{l}\text { ALL - América Latina } \\
\text { Logística S.A. }\end{array}$ & $25 \%$ & Sim & Não & Maioria & Maioria & Maioria & Relação de acionistas presentes \\
\hline 3 & $\begin{array}{l}\text { BHG S.A. - Brazil } \\
\text { Hospitality Group }\end{array}$ & $70 \%$ & Sim & Não & $\begin{array}{c}\text { Aprovado } \\
\text { (não especifica) }\end{array}$ & Unanimidade & $\begin{array}{c}\text { Aprovado } \\
\text { (não especifica) }\end{array}$ & - \\
\hline 4 & $\begin{array}{l}\text { Brasil Brokers } \\
\text { Participações S.A. }\end{array}$ & $43 \%$ & Sim & Não & Unanimidade & - & Maioria & $\begin{array}{l}\text { (i) Relação de acionistas } \\
\text { presentes; (ii) Indicação de votos } \\
\text { proferidos a favor, contra e } \\
\text { abstenções }\end{array}$ \\
\hline 5 & $\begin{array}{l}\text { Brasil Insurance } \\
\text { Participações e } \\
\text { Administração S.A. }\end{array}$ & $>25 \%$ & Sim & Não & Unanimidade & Maioria & Maioria & $\begin{array}{l}\text { (i) Relação de acionistas } \\
\text { presentes; (ii) Indicação de votos } \\
\text { proferidos a favor, contra e } \\
\text { abstenções }\end{array}$ \\
\hline 6 & $\begin{array}{l}\text { Brasilagro - } \\
\text { Companhia Brasileira } \\
\text { de propriedades } \\
\text { Agrícolas }\end{array}$ & $25 \%$ & $\operatorname{Sim}$ & Não & Unanimidade & Maioria & Maioria & $\begin{array}{l}\text { (i) Relação de acionistas } \\
\text { presentes; (ii) Indicação de } \\
\text { abstenções }\end{array}$ \\
\hline 7 & $\begin{array}{l}\text { Brookfield } \\
\text { Incorporações S.A. }\end{array}$ & $>62 \%$ & Sim & Não & Unanimidade & Maioria & - & - \\
\hline 8 & $\begin{array}{l}\text { Companhia de Locação } \\
\text { das Américas }\end{array}$ & $100 \%$ & $\operatorname{Sim}$ & Não & Unanimidade & - & Unanimidade & Relação de acionistas presentes \\
\hline
\end{tabular}


Tabela 6 - Assembleias Gerais Ordinárias (2011)

\begin{tabular}{|c|c|c|c|c|c|c|c|c|}
\hline & $\begin{array}{c}\text { Companhias do } \\
\text { Grupo A }\end{array}$ & $\begin{array}{l}\text { Quórum } \\
\text { Instalação }\end{array}$ & $\begin{array}{c}1^{\mathrm{a}} \\
\text { Convocação }\end{array}$ & $\begin{array}{c}2^{\mathrm{a}} \\
\text { Convocação }\end{array}$ & $\begin{array}{l}\text { Aprovação } \\
\text { Contas }\end{array}$ & $\begin{array}{l}\text { Eleição } \\
\text { Adm. }\end{array}$ & Remuneração & $\begin{array}{l}\text { Detalhamento } \\
\text { dos Votos }\end{array}$ \\
\hline 9 & $\begin{array}{l}\text { Cyrela Brazil Realty S.A. } \\
\text { Empreendimentos }\end{array}$ & $52,685 \%$ & Sim & Não & Unanimidade & Maioria & - & Relação de acionistas presentes \\
\hline 10 & $\begin{array}{l}\text { Cyrela Comercial } \\
\text { Properties S.A. } \\
\text { Empreedimentos e } \\
\text { Participações }\end{array}$ & $90,2238 \%$ & Sim & Não & Unanimidade & Unanimidade & - & Relação de acionistas presentes \\
\hline 11 & $\begin{array}{l}\text { Direcional Engenharia } \\
\text { S.A. }\end{array}$ & $55,65 \%$ & Sim & Não & Unanimidade & - & Unanimidade & Relação de acionistas presentes \\
\hline 12 & Equatorial Energia S.A. & $65,35 \%$ & Sim & Não & Unanimidade & Unanimidade & Maioria & Relação de acionistas presentes \\
\hline 13 & Hypermarcas S.A. & $58 \%$ & Sim & Não & Maioria & Maioria & - & Relação de acionistas presentes \\
\hline 14 & Indústrias Romi S.A. & $25 \%$ & Sim & Não & Unanimidade & Unanimidade & Unanimidade & Relação de acionistas presentes \\
\hline 15 & $\begin{array}{l}\text { International Meal } \\
\text { Company Holdings } \\
\text { S.A. }\end{array}$ & $100 \%$ & Sim & Não & Unanimidade & Unanimidade & Unanimidade & Relação de acionistas presentes \\
\hline 16 & Iochpe Maxion S.A. & $46,3489 \%$ & Sim & Não & Unanimidade & Unanimidade & Unanimidade & Relação de acionistas presentes \\
\hline 17 & JBS S.A. & $>84 \%$ & Sim & Não & Maioria & Maioria & Maioria & Relação de acionistas presentes \\
\hline 18 & Linx S.A. & - & - & - & - & - & - & Relação de acionistas presentes \\
\hline 19 & $\begin{array}{l}\text { Localiza Rent a Car } \\
\text { S.A. }\end{array}$ & $61,35 \%$ & Sim & Não & Unanimidade & Maioria & Unanimidade & $\begin{array}{l}\text { (i) Relação de acionistas } \\
\text { presentes; (ii) Indicação de } \\
\text { abstenções }\end{array}$ \\
\hline 20 & $\begin{array}{l}\text { Magnesita Refratários } \\
\text { S.A. }\end{array}$ & $>62 \%$ & Sim & Não & Unanimidade & Maioria & Maioria & Relação de acionistas presentes \\
\hline
\end{tabular}


Tabela 6 - Assembleias Gerais Ordinárias (2011)

\begin{tabular}{|c|c|c|c|c|c|c|c|c|}
\hline & $\begin{array}{c}\text { Companhias do } \\
\text { Grupo A }\end{array}$ & $\begin{array}{l}\text { Quórum } \\
\text { Instalação }\end{array}$ & $\begin{array}{c}1^{\mathrm{a}} \\
\text { Convocação }\end{array}$ & $\begin{array}{c}2^{\mathrm{a}} \\
\text { Convocação }\end{array}$ & $\begin{array}{l}\text { Aprovação } \\
\text { Contas }\end{array}$ & $\begin{array}{l}\text { Eleição } \\
\text { Adm. }\end{array}$ & Remuneração & $\begin{array}{l}\text { Detalhamento } \\
\text { dos Votos }\end{array}$ \\
\hline 21 & Marfrig Alimentos S.A. & $>25 \%$ & Sim & Não & Unanimidade & Maioria & Maioria & \\
\hline 22 & $\begin{array}{l}\text { Mills Estrutura e } \\
\text { Serviços de Engenharia } \\
\text { S.A. }\end{array}$ & $70,54 \%$ & Sim & Não & Unanimidade & Maioria & Unanimidade & Relação de acionistas presentes \\
\hline 23 & Minerva S.A. & $>75 \%$ & Sim & Não & Unanimidade & - & Maioria & $\begin{array}{l}\text { (i) Relação de acionistas } \\
\text { presentes; (ii) Indicação de } \\
\text { abstenções }\end{array}$ \\
\hline 24 & $\begin{array}{l}\text { MRV Engenharia e } \\
\text { Participações S.A. }\end{array}$ & $25 \%$ & $\operatorname{Sim}$ & Não & Maioria & Maioria & Maioria & Relação de acionistas presentes \\
\hline 25 & Qualicorp S.A. & $100 \%$ & Sim & Não & Unanimidade & Maioria & - & Relação de acionistas presentes \\
\hline 26 & Raia Drogasil S.A. & $>73 \%$ & $\operatorname{Sim}$ & Não & Unanimidade & Maioria & Maioria & Relação de acionistas presentes \\
\hline 27 & Rossi Residencial S.A. & $49,21 \%$ & Sim & Não & Unanimidade & Maioria & Maioria & Relação de acionistas presentes \\
\hline 28 & $\begin{array}{l}\text { T4F Entretenimentos } \\
\text { S.A. }\end{array}$ & $100 \%$ & Sim & Não & Unanimidade & - & Unanimidade & Relação de acionistas presentes \\
\hline
\end{tabular}


Tabela 6.1 - Assembleias Gerais Ordinárias (2012)

\begin{tabular}{|c|c|c|c|c|c|c|c|c|}
\hline & $\begin{array}{c}\text { Companhias do } \\
\text { Grupo A }\end{array}$ & $\begin{array}{l}\text { Quórum } \\
\text { Instalação }\end{array}$ & $\begin{array}{c}1^{\mathrm{a}} \\
\text { Convocação }\end{array}$ & $\begin{array}{c}2^{\mathrm{a}} \\
\text { Convocação }\end{array}$ & $\begin{array}{l}\text { Aprovação } \\
\text { Contas }\end{array}$ & $\begin{array}{l}\text { Eleição } \\
\text { Adm. }\end{array}$ & Remuneração & $\begin{array}{l}\text { Detalhamento } \\
\text { dos Votos }\end{array}$ \\
\hline 1 & $\begin{array}{l}\text { Aliansce Shopping } \\
\text { Centers S.A. }\end{array}$ & $>2 / 3$ & Sim & Não & Unanimidade & Maioria & Unanimidade & - \\
\hline 2 & $\begin{array}{l}\text { ALL - América Latina } \\
\text { Logística S.A. }\end{array}$ & $58,07 \%$ & Sim & Não & Maioria & - & - & $\begin{array}{l}\text { Relação de acionistas } \\
\text { presentes }\end{array}$ \\
\hline 3 & $\begin{array}{l}\text { BHG S.A. - Brazil } \\
\text { Hospitality Group }\end{array}$ & $76 \%$ & Sim & Não & $\begin{array}{l}\text { Não especifica } \\
\text { (aprovado) }\end{array}$ & - & $\begin{array}{l}\text { Não especifica } \\
\text { (aprovado) }\end{array}$ & - \\
\hline 4 & $\begin{array}{l}\text { Brasil Brokers } \\
\text { Participações S.A. }\end{array}$ & $49,51 \%$ & Sim & Não & Unanimidade & Maioria & Unanimidade & $\begin{array}{l}\text { (i) Relação de acionistas } \\
\text { presentes; (ii) Indicação de } \\
\text { votos proferidos a favor, } \\
\text { contra e abstenções }\end{array}$ \\
\hline 5 & $\begin{array}{l}\text { Brasil Insurance } \\
\text { Participações e } \\
\text { Administração S.A. }\end{array}$ & $>58 \%$ & Sim & Não & Maioria & Maioria & Maioria & $\begin{array}{l}\text { (i) Relação de acionistas } \\
\text { presentes; (ii) Indicação de } \\
\text { votos proferidos a favor, } \\
\text { contra e abstenções }\end{array}$ \\
\hline 6 & $\begin{array}{l}\text { Brasilagro - } \\
\text { Companhia Brasileira } \\
\text { de propriedades } \\
\text { Agrícolas }\end{array}$ & $25 \%$ & Sim & Não & Unanimidade & - & Maioria & $\begin{array}{l}\text { (i) Relação de acionistas } \\
\text { presentes; (ii) Indicação de } \\
\text { votos proferidos a favor, } \\
\text { contra e abstenções }\end{array}$ \\
\hline 7 & $\begin{array}{l}\text { Brookfield } \\
\text { Incorporações S.A. }\end{array}$ & $>62 \%$ & Sim & Não & Unanimidade & Maioria & Maioria & - \\
\hline 8 & $\begin{array}{l}\text { Companhia de Locação } \\
\text { das Américas }\end{array}$ & $100 \%$ & Sim & Não & Unanimidade & Maioria & Maioria & - \\
\hline 9 & $\begin{array}{l}\text { Cyrela Brazil Realty } \\
\text { S.A. Empreendimentos }\end{array}$ & $>57 \%$ & Sim & Não & Maioria & Maioria & - & $\begin{array}{l}\text { Relação de acionistas } \\
\text { presentes }\end{array}$ \\
\hline 10 & $\begin{array}{l}\text { Cyrela Comercial } \\
\text { Properties S.A. } \\
\text { Empreedimentos e } \\
\text { Participações }\end{array}$ & $>84 \%$ & Sim & Não & Unanimidade & Unanimidade & - & $\begin{array}{l}\text { Relação de acionistas } \\
\text { presentes }\end{array}$ \\
\hline 11 & $\begin{array}{l}\text { Direcional Engenharia } \\
\text { S.A. }\end{array}$ & $66,17 \%$ & Sim & Não & Unanimidade & Maioria & Maioria & $\begin{array}{l}\text { Relação de acionistas } \\
\text { presentes }\end{array}$ \\
\hline
\end{tabular}


Tabela 6.1 - Assembleias Gerais Ordinárias (2012)

\begin{tabular}{|c|c|c|c|c|c|c|c|c|}
\hline & $\begin{array}{c}\text { Companhias do } \\
\text { Grupo A }\end{array}$ & $\begin{array}{l}\text { Quórum } \\
\text { Instalação }\end{array}$ & $\begin{array}{c}1^{\mathrm{a}} \\
\text { Convocação }\end{array}$ & $\begin{array}{c}2^{\mathrm{a}} \\
\text { Convocação }\end{array}$ & $\begin{array}{l}\text { Aprovação } \\
\text { Contas }\end{array}$ & $\begin{array}{l}\text { Eleição } \\
\text { Adm. }\end{array}$ & Remuneração & $\begin{array}{c}\text { Detalhamento } \\
\text { dos Votos }\end{array}$ \\
\hline 12 & $\begin{array}{l}\text { Equatorial Energia } \\
\text { S.A. }\end{array}$ & $76,53 \%$ & Sim & Não & Unanimidade & - & Unanimidade & $\begin{array}{l}\text { (i) Relação de acionistas } \\
\text { presentes; (ii) Indicação de } \\
\text { abstenções }\end{array}$ \\
\hline 13 & Hypermarcas S.A. & $56 \%$ & Sim & Não & Maioria & Maioria & Maioria & $\begin{array}{l}\text { Relação de acionistas } \\
\text { presentes }\end{array}$ \\
\hline 14 & Indústrias Romi S.A. & $25 \%$ & Sim & Não & Unanimidade & Unanimidade & Maioria & $\begin{array}{l}\text { Relação de acionistas } \\
\text { presentes }\end{array}$ \\
\hline 15 & $\begin{array}{l}\text { International Meal } \\
\text { Company Holdings } \\
\text { S.A. }\end{array}$ & $>50 \%$ & Sim & Não & Unanimidade & - & Maioria & $\begin{array}{l}\text { (i) Relação de acionistas } \\
\text { presentes; (ii) Indicação de } \\
\text { votos proferidos a favor }\end{array}$ \\
\hline 16 & Iochpe Maxion S.A. & $>50 \%$ & Sim & Não & Unanimidade & Unanimidade & Unanimidade & $\begin{array}{l}\text { Relação de acionistas } \\
\text { presentes }\end{array}$ \\
\hline 17 & JBS S.A. & $>90 \%$ & Sim & Não & Unanimidade & - & Unanimidade & $\begin{array}{l}\text { Relação de acionistas } \\
\text { presentes }\end{array}$ \\
\hline 18 & Linx S.A. & $100 \%$ & Sim & Não & Unanimidade & Unanimidade & Unanimidade & $\begin{array}{l}\text { Relação de acionistas } \\
\text { presentes }\end{array}$ \\
\hline 19 & $\begin{array}{l}\text { Localiza Rent a Car } \\
\text { S.A. }\end{array}$ & $>63 \%$ & Sim & Não & Maioria & - & - & $\begin{array}{l}\text { Relação de acionistas } \\
\text { presentes }\end{array}$ \\
\hline 20 & $\begin{array}{l}\text { Magnesita Refratários } \\
\text { S.A. }\end{array}$ & $>62 \%$ & Sim & Não & Maioria & - & Maioria & $\begin{array}{l}\text { Relação de acionistas } \\
\text { presentes }\end{array}$ \\
\hline 21 & $\begin{array}{l}\text { Marfrig Alimentos } \\
\text { S.A. }\end{array}$ & $>73 \%$ & Sim & Não & Unanimidade & - & Maioria & - \\
\hline 22 & $\begin{array}{l}\text { Mills Estrutura e } \\
\text { Serviços de Engenharia } \\
\text { S.A. }\end{array}$ & $72,48 \%$ & Sim & Não & Unanimidade & Maioria & Unanimidade & $\begin{array}{l}\text { Relação de acionistas } \\
\text { presentes }\end{array}$ \\
\hline 23 & Minerva S.A. & $>70 \%$ & Sim & Não & Unanimidade & Maioria & Maioria & $\begin{array}{l}\text { Relação de acionistas } \\
\text { presentes }\end{array}$ \\
\hline
\end{tabular}


Tabela 6.1 - Assembleias Gerais Ordinárias (2012)

\begin{tabular}{|c|c|c|c|c|c|c|c|c|}
\hline & $\begin{array}{c}\text { Companhias do } \\
\text { Grupo A }\end{array}$ & $\begin{array}{l}\text { Quórum } \\
\text { Instalação }\end{array}$ & $\begin{array}{c}1^{\mathrm{a}} \\
\text { Convocação }\end{array}$ & $\begin{array}{c}2^{\mathrm{a}} \\
\text { Convocação }\end{array}$ & $\begin{array}{l}\text { Aprovação } \\
\text { Contas }\end{array}$ & $\begin{array}{l}\text { Eleição } \\
\text { Adm. }\end{array}$ & Remuneração & $\begin{array}{l}\text { Detalhamento } \\
\text { dos Votos }\end{array}$ \\
\hline 24 & $\begin{array}{l}\text { MRV Engenharia e } \\
\text { Participações S.A. }\end{array}$ & $25 \%$ & Sim & Não & Unanimidade & - & - & $\begin{array}{l}\text { Relação de acionistas } \\
\text { presentes }\end{array}$ \\
\hline 25 & Qualicorp S.A. & $>25 \%$ & Sim & Não & Unanimidade & Maioria & Maioria & $\begin{array}{l}\text { Relação de acionistas } \\
\text { presentes }\end{array}$ \\
\hline 26 & Raia Drogasil S.A. & $>60 \%$ & Sim & Não & Unanimidade & - & Unanimidade & $\begin{array}{l}\text { Relação de acionistas } \\
\text { presentes }\end{array}$ \\
\hline 27 & Rossi Residencial S.A. & $47,37 \%$ & Sim & Não & Maioria & Maioria & Maioria & $\begin{array}{l}\text { Relação de acionistas } \\
\text { presentes }\end{array}$ \\
\hline 28 & $\begin{array}{l}\text { T4F Entretenimentos } \\
\text { S.A. }\end{array}$ & $>2 / 3$ & Sim & Não & Unanimidade & - & Unanimidade & $\begin{array}{l}\text { Relação de acionistas } \\
\text { presentes }\end{array}$ \\
\hline
\end{tabular}

Tabela 6.2 - Assembleias Gerais Ordinárias (2013)

\begin{tabular}{|c|c|c|c|c|c|c|c|c|}
\hline & $\begin{array}{c}\text { Companhias do } \\
\text { Grupo A }\end{array}$ & $\begin{array}{l}\text { Quórum } \\
\text { Instalação }\end{array}$ & \begin{tabular}{|c|}
$1^{\mathbf{a}}$ \\
Convocação
\end{tabular} & $\begin{array}{c}2^{\mathbf{a}} \\
\text { Convocação } \\
\end{array}$ & $\begin{array}{l}\text { Aprovação } \\
\text { Contas }\end{array}$ & $\begin{array}{l}\text { Eleição } \\
\text { Adm. }\end{array}$ & Remuneração & $\begin{array}{l}\text { Detalhamento } \\
\text { dos Votos }\end{array}$ \\
\hline 1 & $\begin{array}{l}\text { Aliansce Shopping } \\
\text { Centers S.A. }\end{array}$ & $>2 / 3$ & Sim & Não & Unanimidade & Maioria & Maioria & - \\
\hline 2 & $\begin{array}{l}\text { ALL - América Latina } \\
\text { Logística S.A. }\end{array}$ & $60,07 \%$ & Sim & Não & Maioria & Maioria & Maioria & $\begin{array}{l}\text { Relação de acionistas } \\
\text { presentes }\end{array}$ \\
\hline 3 & $\begin{array}{l}\text { BHG S.A. - Brazil } \\
\text { Hospitality Group }\end{array}$ & $\cong 49 \%$ & Sim & Não & Maioria & Maioria & Maioria & $\begin{array}{l}\text { Indicação apenas de votos } \\
\text { contrários e/ou abstenções }\end{array}$ \\
\hline 4 & $\begin{array}{l}\text { Brasil Brokers } \\
\text { Participações S.A. }\end{array}$ & $51,02 \%$ & Sim & Não & Unanimidade & - & Unanimidade & $\begin{array}{l}\text { (i) Relação de acionistas } \\
\text { presentes; (ii) Indicação de } \\
\text { abstenções }\end{array}$ \\
\hline
\end{tabular}


Tabela 6.2 - Assembleias Gerais Ordinárias (2013)

\begin{tabular}{|c|c|c|c|c|c|c|c|c|}
\hline & $\begin{array}{l}\text { Companhias do } \\
\text { Grupo A }\end{array}$ & $\begin{array}{l}\text { Quórum } \\
\text { Instalação }\end{array}$ & \begin{tabular}{|c|}
$1^{a}$ \\
Convocação
\end{tabular} & $\begin{array}{c}2^{a} \\
\text { Convocação }\end{array}$ & $\begin{array}{l}\text { Aprovação } \\
\text { Contas }\end{array}$ & $\begin{array}{l}\text { Eleição } \\
\text { Adm. }\end{array}$ & Remuneração & $\begin{array}{l}\text { Detalhamento } \\
\text { dos Votos }\end{array}$ \\
\hline 5 & $\begin{array}{l}\text { Brasil Insurance } \\
\text { Participações e } \\
\text { Administração S.A. }\end{array}$ & $>56 \%$ & Sim & Não & Unanimidade & Maioria & Unanimidade & $\begin{array}{l}\text { (i) Relação de acionistas } \\
\text { presentes; (ii) Indicação de } \\
\text { votos proferidos a favor, } \\
\text { contra e abstenções }\end{array}$ \\
\hline 6 & $\begin{array}{l}\text { Brasilagro - } \\
\text { Companhia Brasileira } \\
\text { de propriedades } \\
\text { Agrícolas }\end{array}$ & $25 \%$ & Sim & Não & Unanimidade & Maioria & Maioria & $\begin{array}{l}\text { Indicação apenas de votos } \\
\text { contrários e/ou abstenções }\end{array}$ \\
\hline 7 & $\begin{array}{l}\text { Brookfield } \\
\text { Incorporações S.A. }\end{array}$ & $59,2 \%$ & Sim & Não & Unanimidade & Maioria & Maioria & - \\
\hline 8 & $\begin{array}{l}\text { Companhia de Locação } \\
\text { das Américas }\end{array}$ & $53,48 \%$ & Sim & Sim & Unanimidade & - & Unanimidade & - \\
\hline 9 & $\begin{array}{l}\text { Cyrela Brazil Realty } \\
\text { S.A. Empreendimentos }\end{array}$ & $>25 \%$ & Sim & Não & Unanimidade & - & Maioria & $\begin{array}{l}\text { Relação de acionistas } \\
\text { presentes }\end{array}$ \\
\hline 10 & $\begin{array}{l}\text { Cyrela Comercial } \\
\text { Properties S.A. } \\
\text { Empreedimentos e } \\
\text { Participações }\end{array}$ & $93,68 \%$ & Sim & Não & Maioria & Unanimidade & - & $\begin{array}{l}\text { Relação de acionistas } \\
\text { presentes }\end{array}$ \\
\hline 11 & $\begin{array}{l}\text { Direcional Engenharia } \\
\text { S.A. }\end{array}$ & $67,20 \%$ & Sim & Não & Maioria & Maioria & Maioria & $\begin{array}{l}\text { (i) Relação de acionistas } \\
\text { presentes; (ii) Indicação de } \\
\text { abstenções }\end{array}$ \\
\hline 12 & $\begin{array}{l}\text { Equatorial Energia } \\
\text { S.A. }\end{array}$ & $63,35 \%$ & Sim & Não & Unanimidade & Maioria & Unanimidade & $\begin{array}{l}\text { Relação de acionistas } \\
\text { presentes }\end{array}$ \\
\hline 13 & Hypermarcas S.A. & $66 \%$ & Sim & Não & Maioria & Maioria & Maioria & $\begin{array}{l}\text { Relação de acionistas } \\
\text { presentes }\end{array}$ \\
\hline 14 & Indústrias Romi S.A. & $80,6 \%$ & Sim & Não & Unanimidade & Unanimidade & Maioria & $\begin{array}{l}\text { Relação de acionistas } \\
\text { presentes }\end{array}$ \\
\hline 15 & $\begin{array}{l}\text { International Meal } \\
\text { Company Holdings } \\
\text { S.A. }\end{array}$ & $>50 \%$ & Sim & Não & Maioria & Maioria & Maioria & $\begin{array}{l}\text { Relação de acionistas } \\
\text { presentes }\end{array}$ \\
\hline
\end{tabular}


Tabela 6.2 - Assembleias Gerais Ordinárias (2013)

\begin{tabular}{|c|c|c|c|c|c|c|c|c|}
\hline & $\begin{array}{c}\text { Companhias do } \\
\text { Grupo A }\end{array}$ & $\begin{array}{l}\text { Quórum } \\
\text { Instalação }\end{array}$ & \begin{tabular}{|c|}
$1^{\mathrm{a}}$ \\
Convocação
\end{tabular} & $\begin{array}{c}2^{\mathrm{a}} \\
\text { Convocação }\end{array}$ & $\begin{array}{l}\text { Aprovação } \\
\text { Contas }\end{array}$ & $\begin{array}{l}\text { Eleição } \\
\text { Adm. }\end{array}$ & Remuneração & $\begin{array}{c}\text { Detalhamento } \\
\text { dos Votos }\end{array}$ \\
\hline 16 & Iochpe Maxion S.A. & $>50 \%$ & Sim & Não & Maioria & Maioria & Maioria & - \\
\hline 17 & JBS S.A. & $>74 \%$ & Sim & Não & Maioria & Maioria & Maioria & $\begin{array}{l}\text { Relação de acionistas } \\
\text { presentes }\end{array}$ \\
\hline 18 & Linx S.A. & $75,7 \%$ & Sim & Não & Unanimidade & - & Unanimidade & $\begin{array}{l}\text { Relação de acionistas } \\
\text { presentes }\end{array}$ \\
\hline 19 & $\begin{array}{l}\text { Localiza Rent a Car } \\
\text { S.A. }\end{array}$ & $>67,8 \%$ & Sim & Não & Maioria & Maioria & Maioria & $\begin{array}{l}\text { Relação de acionistas } \\
\text { presentes }\end{array}$ \\
\hline 20 & $\begin{array}{l}\text { Magnesita Refratários } \\
\text { S.A. }\end{array}$ & $>68 \%$ & Sim & Não & Maioria & Maioria & Maioria & $\begin{array}{l}\text { Relação de acionistas } \\
\text { presentes }\end{array}$ \\
\hline 21 & $\begin{array}{l}\text { Marfrig Alimentos } \\
\text { S.A. }\end{array}$ & $>56 \%$ & Sim & Não & Unanimidade & Maioria & Maioria & - \\
\hline 22 & $\begin{array}{l}\text { Mills Estrutura e } \\
\text { Serviços de Engenharia } \\
\text { S.A. }\end{array}$ & $61,23 \%$ & Sim & Não & Unanimidade & - & Maioria & $\begin{array}{l}\text { Relação de acionistas } \\
\text { presentes }\end{array}$ \\
\hline 23 & Minerva S.A. & $\cong 48,20 \%$ & Sim & Não & Unanimidade & Maioria & Maioria & - \\
\hline 24 & $\begin{array}{l}\text { MRV Engenharia e } \\
\text { Participações S.A. }\end{array}$ & $25 \%$ & Sim & Não & Maioria & Maioria & Maioria & $\begin{array}{l}\text { Relação de acionistas } \\
\text { presentes }\end{array}$ \\
\hline 25 & Qualicorp S.A. & $>25 \%$ & Sim & Não & Unanimidade & Maioria & Maioria & - \\
\hline 26 & Raia Drogasil S.A. & $>67 \%$ & Sim & Não & Maioria & Maioria & Maioria & $\begin{array}{l}\text { Relação de acionistas } \\
\text { presentes }\end{array}$ \\
\hline 27 & Rossi Residencial S.A. & $27,01 \%$ & Sim & Não & Unanimidade & Maioria & Unanimidade & $\begin{array}{l}\text { Relação de acionistas } \\
\text { presentes }\end{array}$ \\
\hline 28 & $\begin{array}{l}\text { T4F Entretenimentos } \\
\text { S.A. }\end{array}$ & $>79 \%$ & Sim & Não & Unanimidade & Unanimidade & Unanimidade & $\begin{array}{l}\text { Relação de acionistas } \\
\text { presentes }\end{array}$ \\
\hline
\end{tabular}

